\title{
DepEd ORDER
}

22 AUG 2019

No021 s. 2019

\section{POLICY GUIDELINES ON THE K TO 12 BASIC EDUCATION PROGRAM}

TO: Undersecretaries

Assistant Secretaries

Bureau and Service Directors

Regional Directors

Schools Division Superintendents

Public and Private Elementary and Secondary Schools

All Others Concerned

1. The Department of Education (DepEd) issues the enclosed Policy Guidelines on the $\mathbf{K}$ to 12 Basic Education Program to provide context to and articulate its context, features and programs.

2. The Policy provides a comprehensive explanation of the $\mathrm{K}$ to 12 Basic Education Program and its components across all key stages. It also provides a clear framework for the monitoring and evaluation of the program.

3. The policy integrates many of the existing policies and guidelines on $\mathrm{K}$ to 12 . It also provides a reference point for ongoing and/or future review of any of its components as may be directed by the Secretary.

4. This policy will remain in force and in effect unless sooner repealed, amended, or rescinded.

5. Immediate dissemination of this Order is directed.

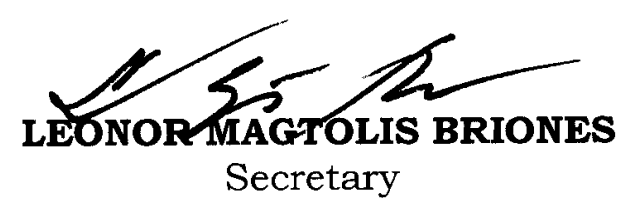

Encls: :

As stated

References:

DepEd Order No. 43, s. 2013; and DepEd Memorandum No. 99, s. 2013

To be indicated in the Perpetual Index

under the following subjects:

ALTERNATIVE LEARNING SYSTEM

CURRICULUM

ELEMENTARY EDUCATION

LEARNERS

POLICY

PROGRAMS

SECONDARY EDUCATION 


\section{THE K TO 12 BASIC EDUCATION PROGRAM}

\section{Background and Rationale}

1. The implementation of the $\mathbf{K}$ to 12 Basic Education Program is considered to be one of the most significant educational reforms in the country. It introduces programs and projects that aim to expand and improve the delivery of basic education in the country. It seeks to provide the Filipino learners with the necessary skills and competence to prepare them to take on the challenges of the $21^{\text {st }}$ Century. It will make the basic education system in the Philippines at par with international standards by ensuring that it is appropriate, responsive, and relevant to the learners.

2. A product of the collaboration with the Commission on Higher Education (CHED), the Technical Education and Skills Development Authority (TESDA), and academe and industry partners, the $\mathrm{K}$ to 12 Basic Education Program of the Department of Education is a curriculum that is accurate in content, at par with the basic education curricula of other Asia-Pacific countries, and, most importantly, appropriate to the learner's development.

3. The studies and proposals for a 12-year basic education reform started as early as 1925 with the Monroe Survey. Until the 1930s, the Philippines actually had 11 years of basic eduçation: seven years of primary and four years of secondary schooling. There had been plans to move the seventh year of primary grades to secondary education and then add another year to make 12 years. However, these plans did not materialize as these were overtaken by various sociopolitical events (Care \& Bacani, 2012).

4. The Department of Education, recognizing the need and significance of preparing pre-school learners for daily life and schooling, pursued many initiatives to establish the Kindergarten Program. This included the issuance of a policy document in 1971 which encouraged Schools Division Offices (SDOs) to establish preschool classes. In 2008, DepEd subsidized the honorarium of volunteer kindergarten teachers. To reach more five-year-old children (especially those without preschool experience) and ensure their readiness for school, Summer Preschool Education was implemented in 2010.

5. Among the most relevant breakthroughs was the passing of Republic Act (RA) No. 8980 (The Early Childhood Care and Development Act) which sustained an inter-agency and multi-sectoral collaboration to guarantee delivery of holistic services to children up to 6 years old.

6. At the international front, the ASEAN 2015 charted the economic integration of the region. To meet the goals articulated in this document, the Association of Southeast Asian Nations (ASEAN) began working on a Qualifications Reference Framework (AQRF) that would enable comparisons of education qualifications among member states. Being the only ASEAN country with less than 12 years of basic education became further motivation for the Philippines to extend its secondary education by two years.

7. On January 20, 2012, Republic Act No. 10157 (Kindergarten Education Act of 2012) was passed into law, making Kindergarten mandatory for all learners. Its Implementing Rules and Regulations (IRR) are found in DepED Order (DO) No. 32 , s. 2012. 
8. On May 15, 2013, Republic Act No. 10533 otherwise known as the Enhanced Basic Education Act of $\mathbf{2 0 1 3}$ was passed into law. RA 10533 added two years of Senior High School (SHS) to broaden the goals of high school education for college preparation, vocational and technical career opportunities as well as creative arts, sports and entrepreneurial employment. It also makes education learner-oriented and responsive to the needs, cognitive and cultural capacity, and the circumstances of learners, schools and communities through the use of appropriate mediums of teaching and learning, including mother tongue.

9. The Department of Education issues these Policy Guidelines on the $\mathrm{K}$ to 12 Basic Education Program to unify the understanding of $\mathrm{K}$ to 12 and to improve the implementation of each component, project and activity under it.

\section{Policy Objectives}

10. This policy aims to:

a. Explain the $\mathrm{K}$ to 12 curriculum and the programs for each key stage, describe the learner and his/her capabilities at each key stage, and show the curriculum, instruction and assessment for each key stage;

b. Establish the components required to ensure effective implementation of the curriculum;

c. Establish the framework to be used for monitoring and evaluation;

d. Set the frameworks for the different dimensions of the $\mathrm{K}$ to 12 Curriculum; and,

e. Guide the central, regional, and schools division offices, and schools, in effectively organizing and managing the implementation of the K to 12 Basic Education Program.

\section{Scope}

11. This policy is intended to guide the central, regional, and schools division offices, and schools in effectively organizing and managing the implementation of the $\mathrm{K}$ to 12 Basic Education Program. It aims to provide concrete basis for developing programs, policies and issuances relative to the implementation of the $\mathrm{K}$ to 12 Basic Education Program at each governance level of the Department. The policy also benefits other stakeholders, such as partners and partner schools, NGOs, parents, and advocates, among others, by providing a comprehensive explanation of what the program is, so that they may contribute to its effective implementation and improvement.

\section{Definition of Terms}

12. For the purposes of this policy, the following terms are defined:

a. Competency - This refers to a specific skill performed with varying degrees of independence. It has different degrees of difficulty and performance levels. It also refers to the ability to perform activities according to the standards expected by drawing from one's knowledge, skills and attitudes.

b. Content - This is the scope and sequence of topics and skills covered in each strand/domain/theme/component. 
c. Key stage - This refers to stages in the $\mathrm{K}$ to 12 Program reflecting distinct developmental milestones. Assessment of learning is critical at the end of each stage. These are Key stage 1 (Kindergarten to Grade 3); Key stage 2 (Grade 4 to Grade 6); Key stage 3 (Grade 7 to Grade 10); and Key stage 4 (Grades 11 and 12).

d. Key Stage Standard - This shows the degree or quality of proficiency that the learner is able to demonstrate in each key stage after learning a particular learning area in relation to the core learning area standard.

e. National Certificate - It is a certification issued by TESDA to individuals who have been assessed to have achieved all the required competencies for a qualification with promulgated Training Regulations.

f. Skill - It is the coordinated performance of related tasks with a certain degree of facility.

g. Standard - In its broadest sense, it is something against which other things can be compared to for the purpose of determining accuracy, estimating quantity or judging quality. It is a stated expectation of what one should know and be able to do.

h. $21^{\text {st }}$ century skills - These are the knowledge, skills, attitudes and competencies that learners need to develop so that they can prepare for and succeed in work and life in the 21 st century.

\section{Policy Statement}

13. As prescribed by Republic Act No. 10533, DepEd shall adhere to the following principles in pursuit of the $\mathrm{K}$ to 12 Basic Education Program:

a. The curriculum shall be learner-centered, inclusive, developmentally relevant and appropriate. Learner-centered is an approach to education that puts the needs and interests of the students at the center of the teaching-learning process.

b. The curriculum shall be relevant, responsive and research-based. It is based on learning theories, principles, sound research, and studies in teaching and learning dynamics.

c. The curriculum shall be culture-sensitive which means that instruction must respect the cultural identities of the learners.

d. The curriculum shall be contextualized and global. Relevant, appropriate, and responsive curriculum will only become a reality if it puts a premium on the personal, bio-geographical and socio-cultural setting of the learners, taking into account the demands of the national and global community.

e. The curriculum shall use pedagogical approaches that are constructivist, inquiry-based, reflective, collaborative, differentiated, and integrative. Constructivism views learners as active constructors of meaningful 
knowledge. Inquiry-based learning puts a premium on questioning, investigating, proving, probing, explaining, predicting, and establishing connection of evidences. Reflective learning provides opportunities for learners to reflect on what and why they need to learn and how to go about it. Collaborative approach allows learners to share ideas between and among themselves thus developing the value of cooperation, respect, camaraderie, and tolerance. Differentiation takes into great consideration the different learning styles and multiple intelligences of the learners, which are significant aspects of their individual differences not only as learners but also as individuals. Finally, integrative pedagogy espouses the importance of connections and relationships of ideas and concepts between and among disciplines.

f. The curriculum shall adhere to the principles and framework of Mother Tongue-Based Multilingual Education (MTB-MLE) in the early grades. Instructional materials and capable teachers to implement the MTB-MLE curriculum shall be available. The guidelines on the implementation of the MTB-MLE program are further explained in Annex 4.

g. The curriculum shall use the spiral progression approach to ensure mastery of knowledge and skills after each level. This pedagogical feature follows the idea that concepts are introduced at an early age and deepened in succeeding years.

h. The curriculum shall be flexible enough to enable schools to localize, indigenize and to enhance it based on their respective educational and social contexts. The production and development of locally produced teaching materials shall be encouraged and the approval of these materials shall be devolved to the regions and divisions, subject to approved standards and monitoring at the central level.

\section{The Learner}

14. The Learner refers to any individual, regardless of age, sex, ethnicity, culture, religion, and ability, enrolled in basic education to enhance his/her knowledge, skills, and values to improve the quality of his/her life, and to develop his/her potentials. DepEd provides all learners with many opportunities to access quality basic education. Learners in difficult circumstances, which prevent them from attending school regularly, have Flexible Learning Options (FLOs) so they may complete basic education, including the Alternative Learning System (ALS) where appropriate. Learners who are gifted and talented, learners with disabilities, and learners from specific cultural contexts and religious beliefs will be helped to attain their full potential through equitable, relevant, appropriate, and responsive educational interventions. Learners who are temporarily abroad may attend schools that offer $\mathrm{K}$ to 12 curriculum following the regulations of their host country, so they can return to the Philippine education system seamlessly.

15. The goal of the $\mathrm{K}$ to 12 curriculum is for all learners to have access to quality and relevant education. In effect, all learners have the opportunity to become well-rounded, happy, and smart individuals who are confident to pursue their chosen paths. 


\section{Inclusive Education}

16. Inclusive education is the core principle of the $\mathrm{K}$ to 12 Basic Education Program. This promotes the right of every Filipino to quality, equitable, culturebased and complete basic education. Through inclusive education, all Filipinos will realize their full potential and contribute meaningfully to building the nation. The Inclusive Education Policy Framework is discussed in Annex 5.

\section{The Enhanced Basic Education Program: $\mathrm{K}$ to 12}

17. The Enhanced Basic Education Program or $\mathrm{K}$ to 12 Basic Education Program responds to national and global community needs and demands through its mission to strengthen the values of the Filipino people, develop a strong sense of nationalism, develop productive citizens who contribute to the building of a progressive, just, and humane society, ensure environmental sustainability, and cultivate global partnerships for development.

18. The $\mathrm{K}$ to 12 graduate is a holistically developed Filipino who has built foundations for learning throughout life. They are individuals equipped with information, media and technology skills, learning and innovation skills, life and career skills, and communication skills necessary to tackle the challenges and take advantage of the opportunities of the $21^{\text {st }}$ century. These skills are defined and described as follows:

a. Information, media and technology skills deal with various sub-skills such as visual and information literacies, media literacy, basic, scientific, economic and technological literacies, multicultural literacy, and global awareness. These skills allow learners to navigate the fluid and dynamic environment of knowledge creation and acquisition. These skills are embedded in subjects such as Technology and Livelihood Education, Science, Mathematics, Araling Panlipunan, MAPEH, and Languages, which are all subjects used as platforms for integration of these skills.

b. Learning and innovation skills include among others creativity and curiosity, critical thinking, problem-solving, adaptability, managing complexity and self-direction, and sound reasoning skills. Acquisition of these skills help learners resolve daily issues and challenges be it academic, personal, social, etc. Learning and innovation skills are honed in all subject areas and across grade levels.

c. Communication skills enable learners to easily adapt to present and future challenges and opportunities. Teaming, collaboration, interpersonal skills, and interactive communication are parts and parcels of the $21^{\text {st }}$ century learning and are integrated in all learning areas, which are gradually developed through the learning competencies and performance standards.

d. Life and career skills empower learners to make informed decisions, thereby giving them the leverage to significantly contribute to the development of society. Flexibility and adaptability, initiative and selfdirection, social and cross-cultural skills, productivity and accountability, leadership, and responsibility form part of the said skills. 
These skills, coupled with curriculum support system and DepEd core values, are designed to holistically prepare the $\mathrm{K}$ to 12 learners to become effective in helping address the needs of the nation, by pursuing higher education, employment, entrepreneurship, or middle-level skills development.

As a result, $\mathrm{K}$ to 12 graduates are able to engage in productive and creative undertakings individually or collaboratively.

19. Specific curricular features in the different key stages are discussed in detail in the succeeding annexes. The $\mathrm{K}$ to 12 Program covers 13 years of basic education with the following key stages:

a. Kindergarten to Grade 3 (Primary School)

b. Grade 4 to 6 (Middle School)

c. Grades 7 to 10 (Junior High School)

d. Grades 11 to 12 (Senior High School)

20. Details about Key Stages 1 and 2 are found in Annex 1, while Annex 2 presents the details on Key Stages 3 and 4 . Flexible learning options for learners who are unable to participate fully in formal schooling due to various reasons are available through alternative delivery modes and the Alternative Learning System, as discussed in Annex 3.

\section{Pathways and Equivalencies}

21. To enable all learners to attain basic education, pathways and equivalencies are in place to provide different routes to basic education for over-aged and adult learners. Their path will be determined by their life and employment

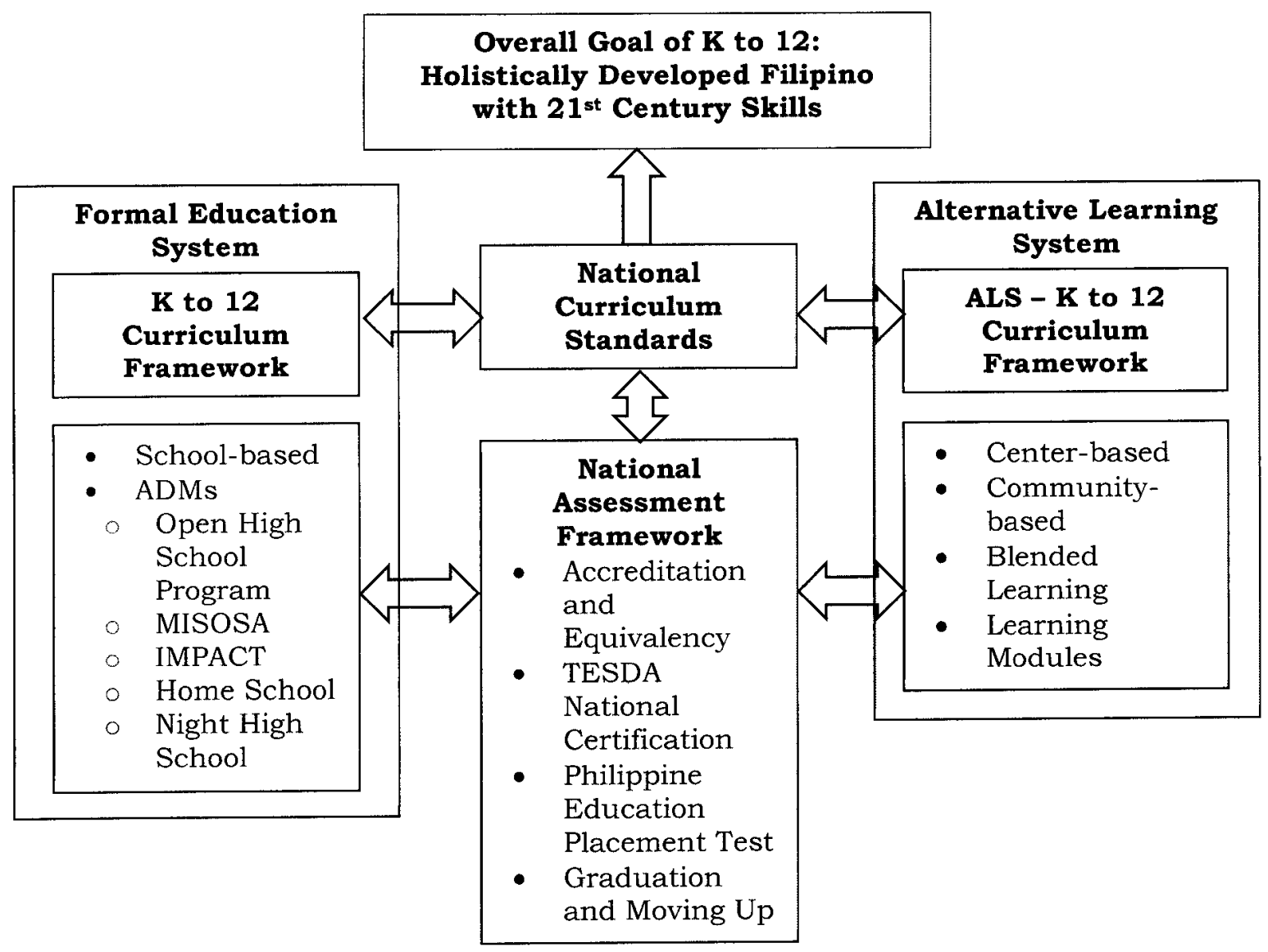


experiences and their purpose for seeking basic education. The conceptual paradigm in Figure 1.1 shows the pathways and equivalencies between the formal education system and the alternative learning system.

\section{The $\mathrm{K}$ to 12 Conceptual Framework}

22. Every learner who completes the $\mathrm{K}$ to 12 basic education program will have been nurtured and developed to become a Filipino with 21 st century skills. The attainment of this objective is founded on the recognition of the nature, contexts, and needs of learners. The graduates of the $\mathrm{K}$ to 12 Program will have the necessary physical, cognitive, socio-emotional, and moral preparation so they can determine their own purposes for learning in consideration of current and emerging needs of their immediate, local, national, and global communities.

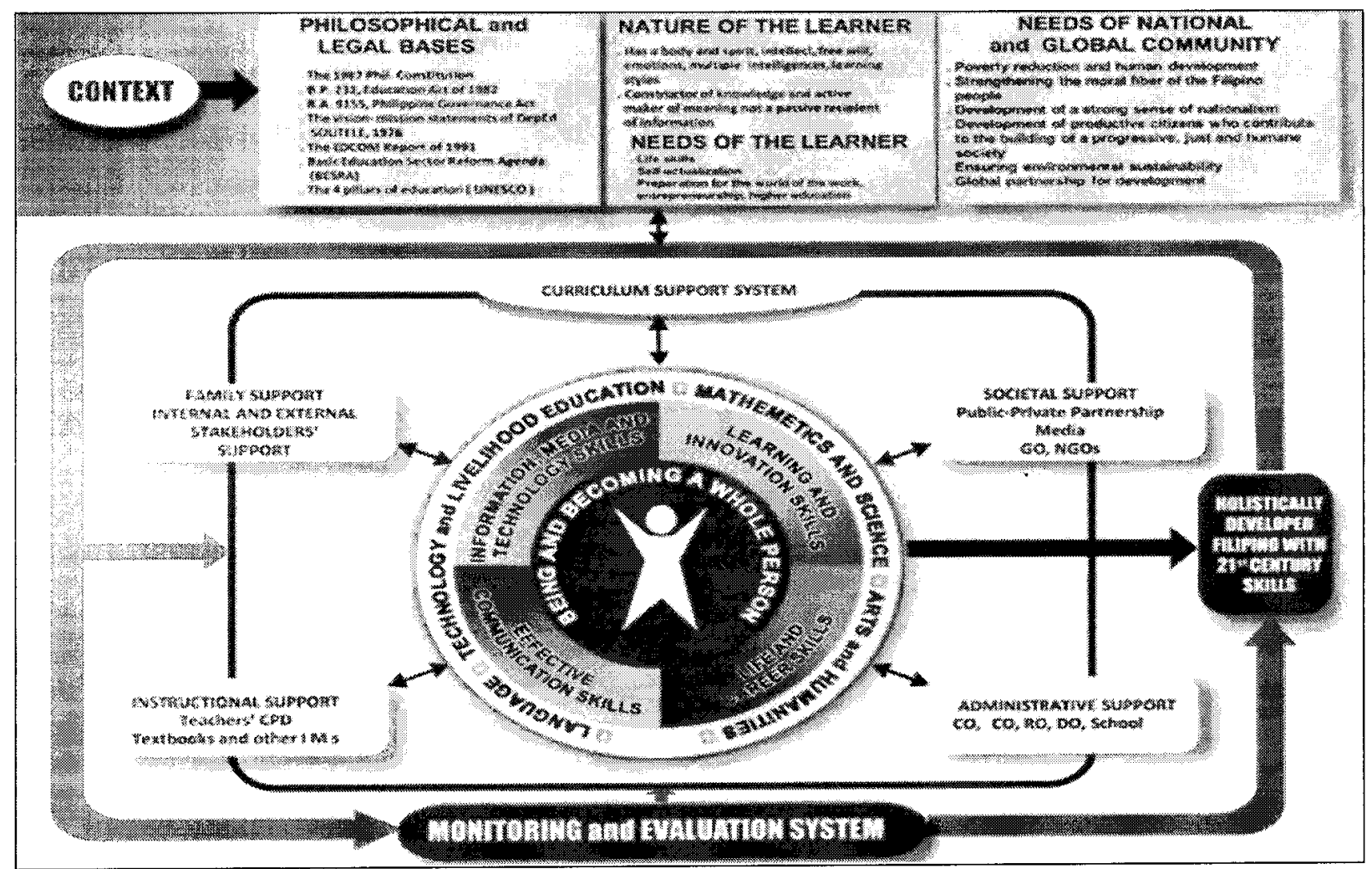

\section{Figure 1.2 The $\mathrm{K}$ to 12 Conceptual Framework}

23. The $\mathrm{K}$ to 12 graduate is equipped with the following 21 st century skills: (1) information, media and technology skills; (2) learning and innovation skills; (3) communication skills; and (4) life and career skills. These skills are embedded in the curriculum, and gradually developed through the learning competencies and performance standards. This is illustrated in Figure 1.2.

24. Education provides contextualized practice for the application of $21^{\text {st }}$ century skills as these are embedded in different learning areas. When learners finish $\mathrm{K}$ to 12 basic education, they are then able to apply these to life. The DepEd envisions Filipinos who are ready for four possible exits: employment, entrepreneurship, middle level skills development, and higher education. These options are shown in Figure 1.3. 


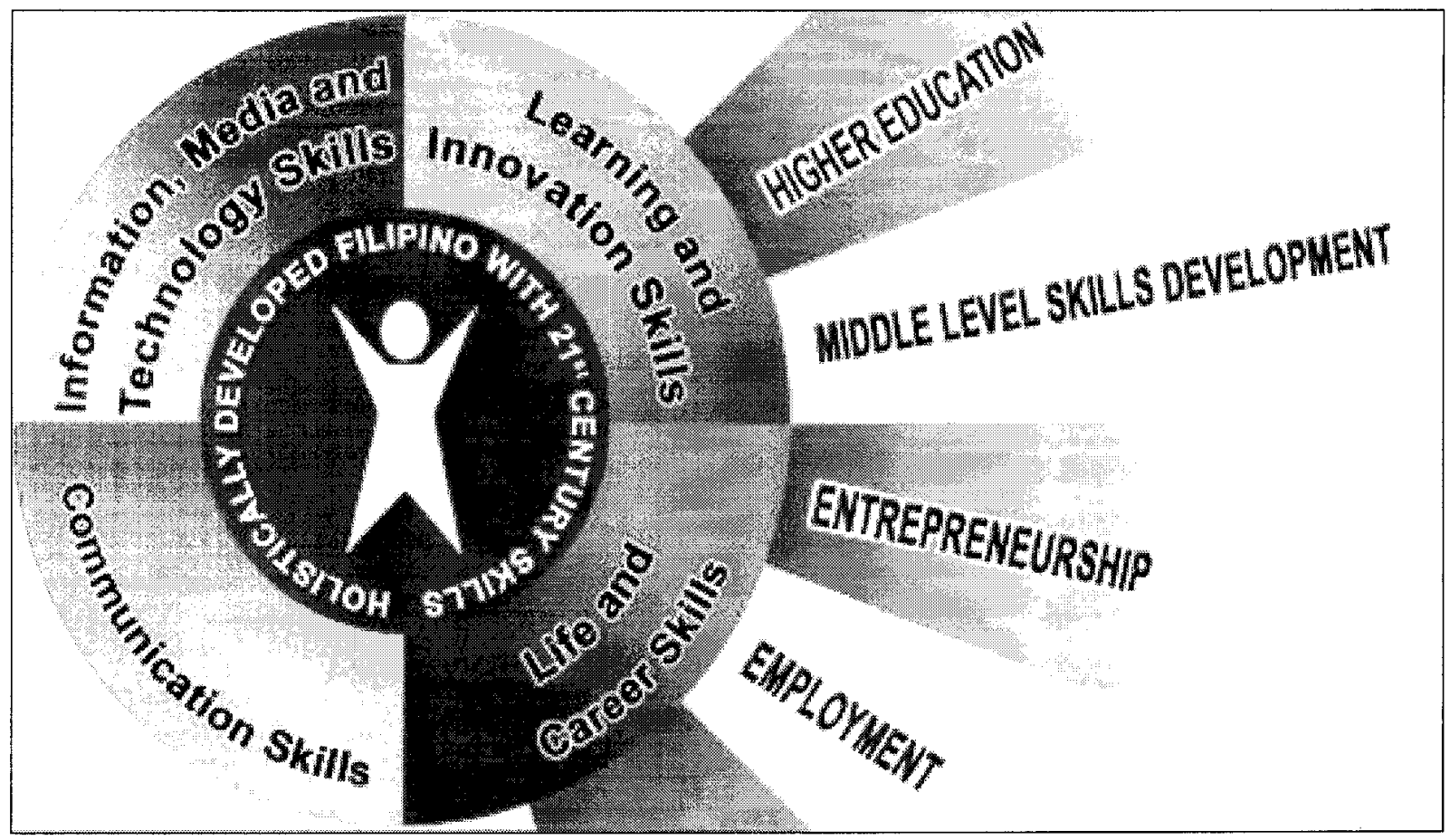

Figure 1.3. Curriculum Exits

25. In formal education, learning areas are taught using interdisciplinary and multidisciplinary approaches. Science is taught in relation to Math and vice versa. The content in Science, Health, Art, and Physical Education may become reading materials in English, or the content in Araling Panlipunan and Edukasyon sa Pagpapakatao may serve as reading materials in Filipino. What is taught in Science is reinforced by the lessons in Health. Current issues may be easily integrated in the curriculum because it is possible to incorporate them in various lessons; likewise, there are many avenues for discussion and reinforcement.

26. In non-formal education, the learning areas are found in integrated lessons within the following learning strands of the ALS: (1) Communication Skills (English and Filipino); (2) Scientific Thinking and Critical Thinking Skills; (3) Mathematical and Problem-Solving Skills; (4) Life and Career Skills; (5) Understanding the Self and Society; and (6) Digital Literacy.

27. In both formal and non-formal education, learning is both collaborative and contextualized. As such, teaching and learning comes from a combination of group work or teamwork, triad, dyad, and independent work. Co-curricular activities and community involvement complement teaching and learning in the classroom. When learning is designed this way, there will be many opportunities to connect with classmates, teachers, peers, family, as well as the community.

\section{Features of the $\mathrm{K}$ to 12 Curriculum}

28. The learner is at the center of the teaching-learning process. Thus, the curriculum uses pedagogical approaches that are constructivist, inquiry-based, reflective, collaborative, differentiated, appropriate, relevant, and integrative.

29. The curriculum is articulated in terms of standards and competencies and is seamless, research-based and decongested. It uses the spiral progression 
approach to ensure mastery of knowledge and skills after each level. Information and Communications Technology (ICT) competencies have been integrated into the curriculum to equip learners with skills that will enable them to cope with the technological demands of our time.

\section{a. $\mathbf{K}$ to 12 Curriculum Support System}

30. To ensure the implementation and actualization of the intended curriculum as contained in the Curriculum Guides, a strong support system is an essential part of $\mathrm{K}$ to 12 . The curriculum serves as basis for the different offices in DepEd to identify the standards for each curriculum support system component.

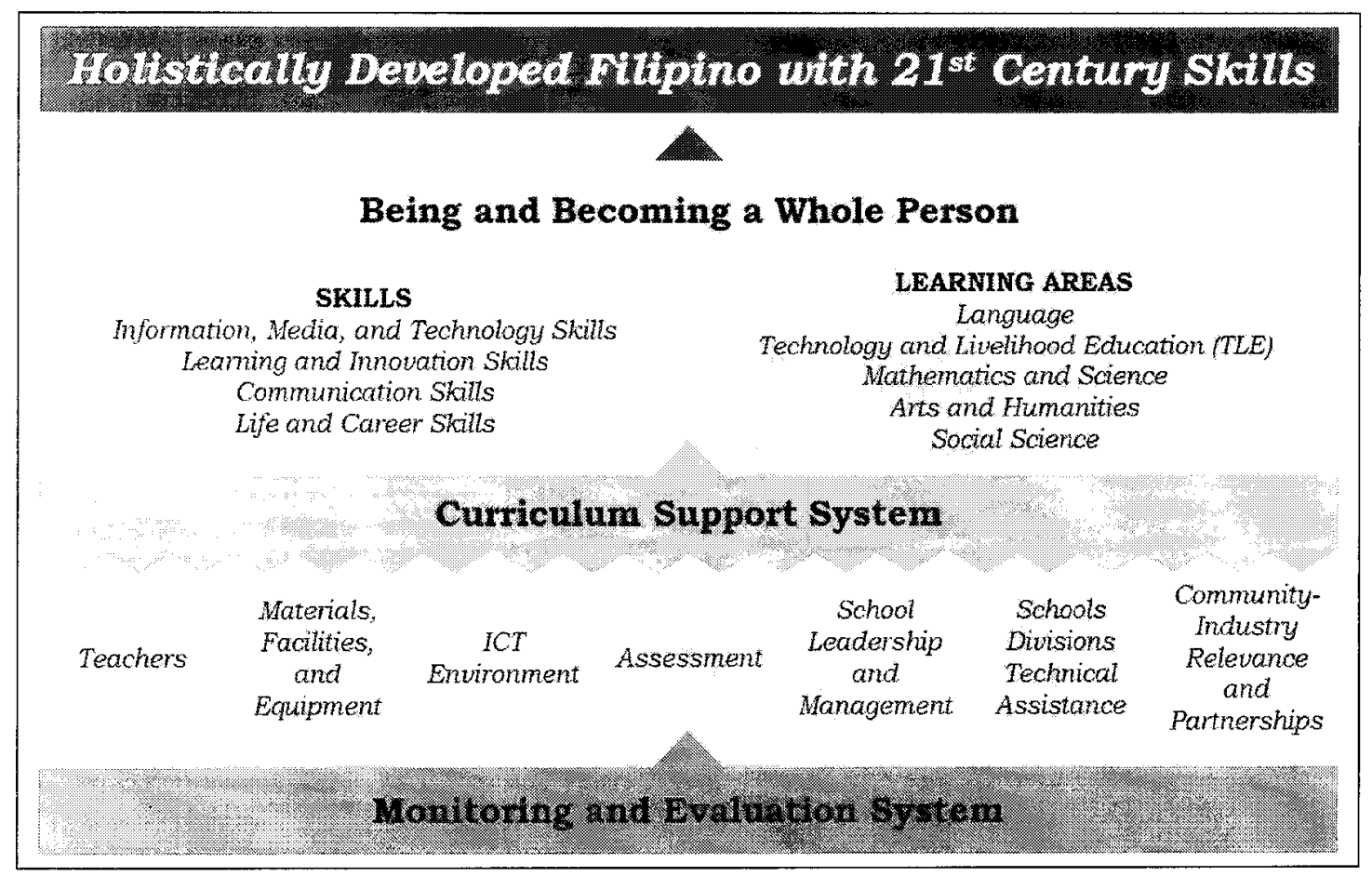

Figure 1.4 Curriculum Support System

31. Figure 1.4 identifies the components which make up the curriculum support system. These components are described more comprehensively below:

\section{Teachers}

32. The $\mathrm{K}$ to 12 Reform has changed the landscape of teacher quality requirements in the Philippines. The reform process warrants an equivalent supportive focus on equipping and preparing teachers to deliver the $\mathrm{K}$ to 12 curriculum. Through D.O. 42 s. 2017, DepEd adopted the Philippine Professional Standards for Teachers (PPST). Building on the National Competency-Based Teacher Standards (NCBTS), the PPST articulates what constitutes teacher quality in K to 12 Reform across well-defined domains, strands, and indicators that provide measures of professional learning, competent practice, and effective engagement. The PPST establishes the standards that define teacher quality through four career stages: Beginning, Proficient, Highly Proficient, and Distinguished. It is founded on teaching philosophies of learner-centeredness, lifelong learning, and inclusiveness, among others. 
33. The PPST is operationalized through various mechanisms including teacher professional development programs, career progression and the assessment of progress and teachers, and Learning Action Cells (LACs). Continuing Professional Development (CPD) as mandated by R.A. 10912 is also being implemented.

\section{Materials, Facilities, and Equipment}

34. Text-based and non-text-based learning resources suitable to the needs of learners are aligned with the curriculum, addressing the learning competencies found in the curriculum guides. Each learning resource is tagged with its corresponding competency codes. These materials are provided to all learners and teachers for the enhancement of the learning and teaching process.

35. Text-based learning resources include textbooks (TX), teacher's manuals (TM), learner's materials (LM), teacher's guides (TG), readers, and worksheets undergo a rigorous screening and evaluation process prior to their publication and/or distibution. These learning resources are also transcribed into Braille. Learning resources for subjects taught in the mother tongue are contextualized in the regions and divisions. Modules and Basic Literacy Learning Materials (BLLMs) were developed for ALS learners based on the enhanced ALS curriculum, while materials were also created for Madrasah Education. The Learning Resource Management and Development System (LRMDS) has been developed to provide an arrangement for assessing, acquiring, adapting, developing, producing and distributing quality learning and teaching resource materials for students and teachers. It is supported by the collaborative work among the central and regional, division, and school personnel on ways of improving access to quality instructional and learning materials. A database of the curriculum guides and digital copies of these learning resources tagged with their respective competency codes are made available and free to use at the Learning Resource (LR) portal (1rmds.deped.gov.ph). Tagged print resources include Learner's Materials, Teacher's Guides and ALS materials which have been previously distributed to schools but are still relevant for specific learning competencies.

36. Due to the diversity and number of Senior High School subjects, learning resources are classified into five "course packs", each with specific learning resources. A reader is recommended for topics that can stand alone such as Humanities subject, complemented with a teacher's guide, while a manual is for skills building and procedural topics, as seen in TVL subjects. Activities can be included in these materials or a separate activity workbook may be recommended for subjects in the arts. Proposals for the development and use of videos presenting procedures and lectures are also made for highly technical subjects in the sciences and TVL, and specialized subjects in the arts and sports track to aid both learners and teachers in deepening their understanding of the topics.

37. The non-text-based learning resources are the tools and equipment for science, math, and technical-vocational-livelihood (TVL) classes. Their technical specifications have been identified and placed in the Tools and Equipment Database and uploaded in the LR portal. Non-text learning resources have been tagged with competencies using the learning competency code. These can be found in the curriculum guides uploaded in the website.

\section{ICT Environment}


38. The Department envisions Information and Communications Technology (ICT) as a powerful tool and an important medium in delivering curriculum content. To identify possible areas for ICT integration in the teachinglearning process, the ICT Framework will be discussed in detail in a separate policy issuance. Included in the framework are the types of contexts and situations wherein ICT integration takes place (i.e. classroom instruction, distance learning, education services for learners with disabilities, digital literacy). It also covers tools and systems used by the Department to support curriculum implementation and sector management, such as technology packages for learners through the DepEd Computerization Program (DCP), digital learning resource repositories, teacher training on ICT and various e-tools, and information systems that support the delivery of basic education.

\section{Assessment}

39. Assessment is conducted through a) classroom-based assessments, and b) system assessments, which may be national or international. Classroombased assessment is composed of formative and summative assessments administered by teachers in their classrooms. It is discussed in detail in DepEd Order No. 8, s. 2015. In addition, DepEd Order No. 36, s. 2016 discusses the honors and awards that may be given to learners at specific points in the school year.

40. On the other hand, the national assessment of student learning is composed of national large-scale assessments which are administered to learners at specific times. These are described in detail in DepEd Order No. 55, s. 2016.

41. The results of the large-scale assessments feed into the system assessment of DepEd, together with data gathered from international large-scale assessments, which the Philippines has opted to participate in for specific learning areas. These national and international assessments are listed and discussed in DepEd Order No. 29, s. 2017.

\section{School Leadership and Management}

42. The National Educators Academy of the Philippines (NEAP), together with the Bureau of Human Resources and Organizational Development (BHROD) lead the implementation of the Professional Development Program for Principals and Schools Division Superintendents (SDSs). The new Philippine Professional Standards for School Heads and the Philippine Professional Standards for Supervisors are currently in their final validation phase.

\section{Schools Divisions Technical Assistance}

43. DepEd Order No. 52, s. 2015 enumerates the functions of all offices at the different levels of governance in DepEd.

44. However, a more detailed iteration of how technical assistance should be provided to schools and other role/s that schools division offices undertake are in the policies released for specific programs. For example, roles of the various levels of DepEd governance are specified in DepEd Order No. 12, s. 2015 (Guidelines on the Early Language, Literacy and Numeracy Program: Professional Development Component). 
45. DepEd Order No. 51, s. 2015 (Guidelines on the Implementation of the SHS Program in Existing Public JHSs and ISs, Establishment of Stand-Alone Public SHSs, and Conversion of Existing Public Elementary and JHSs Into Stand-Alone SHSs) and DepEd Order No. 26, s. 17 (Addendum to DepEd Order No. 51, s. 2015) contain the systems and procedures on the implementation of SHS.

\section{Community-Industry Relevance and Partnerships}

46. Guidelines on Partnerships are discussed in DepEd Order No. 40, s. 2015. It itemizes areas for partnerships, steps to be done to build partnerships, responsible personnel, and sample tools and templates.

\section{Monitoring and Evaluation}

47. The Basic Education Monitoring and Evaluation Framework (BEMEF) has been established to ensure that the objectives of the program are met.

48. The $\mathrm{K}$ to 12 Program defines the expected competencies of $\mathrm{K}$ to 12 graduates, based on 21 st century skills as contained in the curriculum. The Enabling Environment refers to the mechanism for DepEd to ensure all learners develop holistically. The status of learners informs the DepEd of how effective its support systems are, while the Enabling Environment represents the Department's systems, policies, programs and projects.

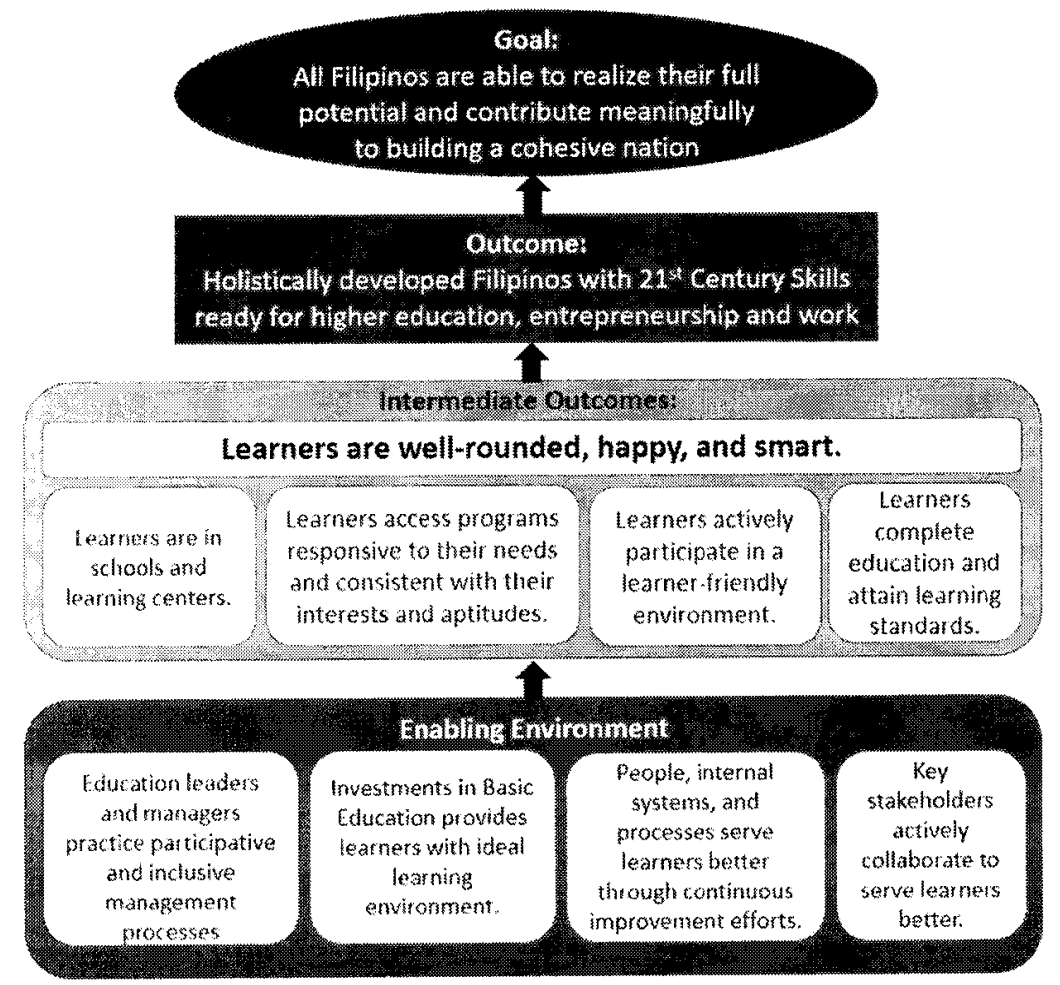

\section{Figure 1.5 Basic Education Monitoring and Evaluation Framework}

49. The Basic Education Monitoring and Evaluation Framework shown in Figure 1. 5 presents key education objectives with the learner's characteristics as the main indicators of success. This Framework represents a major shift from the use of school-level data to explain the performance of the basic education sub-sector to a more learner-centered description of learners' performance and needs. 
50. The $\mathrm{K}$ to 12 system introduced critical reforms in service delivery and redefined the competencies expected from basic education graduates. The outcomes of these reforms shall be measured for the following purposes:

a. Establishing baseline data/information relative to the implementation of a new curriculum;

b. Measuring the effectiveness of curriculum implementation;

c. Providing evidence for planning, programming and policy formulation for efficient and effective curriculum implementation; and

d. Determining variability within the system across regions in terms of curricular areas, grade levels and programs.

51. The wealth of assessment data derived from the following internal and external assessments shall be utilized in the planning, monitoring and evaluation (M\&E) cycles of the Department:

a. Large-scale assessments measure student learning outcomes in particular learning areas. Internal/national assessments are conducted by the Department of Education. External/international assessments are conducted by international organizations such as the Organization for Economic Cooperation and Development (OECD) and the International Association for the Evaluation of Educational Achievement (IEA). The Department of Education may select which international assessments to participate in.

b. System assessment measures the effectiveness of an educational system. It is designed to determine the degree to which the system goals are achieved across regions, curricular areas and learners. It also provides evidence and data that may be used for monitoring and evaluation.

c. Student learning outcome is the totality of information, knowledge, understanding, attitudes, values, skills, competencies or behaviors an individual is expected to master upon successful completion of an educational program (UIS, 2011). The outcome of these teaching-learning educational processes is usually measured through standardized tests. The test results can be used as proxy indicator to measure effectiveness of the educational system.

52. The Bureaus under the Office of the Undersecretary for Curriculum and Instruction, and their counterparts at the Region and Division level shall be responsible in the execution of this monitoring and evaluation framework, for reporting to the Secretary and the rest of the Department leadership. 


\section{References}

1987 Constitution of the Republic of the Philippines

Association of Southeast Asian Nations. "ASEAN Qualifications Reference Framework." http://asean.org/asean-economic-community/sectoralbodies-under-the-purview-of-aem/services/asean-qualificationsreference-framework/ (accessed 2 June, 2017)

Batas Pambansa Bilang 232, "Education Act of 1982"

Board of National Education, General Policies on Education, 1967-1972, 1951$1961 \& 1958-1960$

Care, Esther and Ramon Bacani, "Analysis of Basic Education of the Philippines: Implications for the K to 12 Education Program," 2012.

Department of Education Order No. 62, s. 2011, "Adopting the National Indigenous People Education Policy Framework."

Department of Education Order No. 103, s. 2011, "Creation of the Indigenous Peoples Education Office."

Department of Education Order No. 32, s. 2012, "Implementing Rules and and Regulations of Republic Act (RA) no. 10157 Otherwise Known as "The Kindergarten Education Act"

Department of Education Order No. 73, s. 2012, "Guidelines on the Assessment and Rating of Learning Outcomes Under the $\mathrm{K}$ to 12 Basic Education Curriculum."

Department of Education Order No. 8, s. 2015, "Policy Guidelines on Classroom Assessment for the $\mathrm{K}$ to 12 Basic Education Program."

Department of Education Order No. 32, s. 2015, "Adopting the Indigenous Peoples Education Curriculum Framework."

Department of Education Order No. 52, s. 2015, "New Organizational Structures of the Central, Regional, and Schools Division Offices of the Department of Education."

Department of Education Order No. 47, s. 2016, "Omnibus Policy on Kindergarten Education."

Department of Education Order No. 55, s. 2016, "Policy Guidelines on the National Assessment of Student Learning for the K to 12 Basic Education Program."

Department of Education Order No. 42, s. 2017, "National Adoption and Implementation of the Philippine Professional Standards for Teachers (PPST)"

Implementing Rules and Regulations of R.A. 10533, "The Enhanced Basic Education Act of 2013." 
Presidential Decree 603, Children and Youth Welfare Code.

Republic Act 10157, "Kindergarten Education Act of 2012"

Republic Act 10533, “The Enhanced Basic Education Act of 2013”

Republic Act 8980, "The Early Childhood Care and Development Act"

Republic Act 9155, "Governance of Basic Education Act of 2001"

Republic Act 9442, "An Act Amending RA 7277 otherwise known as the "Magna Carta for Disabled Persons and Other Purposes," http:/ / www.ncda.gov.ph/disability-laws/republic-acts/republic-act9442/ (accessed 9 May 2017)

UNESCO Institute for Statistics, "Learning Outcomes definition," htip://uis.unesco.org/en/glossary-term/learning-outcomes (accessed 3 March 2-2019) 


\section{ANNEX 1: ELEMENTARY EDUCATION}

\section{Introduction}

1. Elementary education is crucial to the promotion of the child as an individual, a member of a family and community, and a learner in school. Developing children for life and learning is based not only on knowledge of children's developmental milestones. Teachers should also understand the child's social, cultural, community and family backgrounds, and the current circumstances in which the child finds himself/herself. These backgrounds lead to diversity in childhood and shape different patterns of development and learning.

2. The objectives of elementary education, as stated in Batas Pambansa (BP) No. 232, or The Education Act of 1982, are:

a. To provide the knowledge and develop the skills, attitudes, and values essential to personal development and necessary for living in and contributing to a developing and changing social milieu;

b. To provide learning experiences that increase the child's awareness of and responsiveness to the changes in and just demands of society, and to prepare him/her for constructive and effective involvement;

c. To promote and intensify the child's knowledge of, identification with, and love for the nation and the people to which he/she belongs; and

d. To promote work experiences that develop the child's orientation to the world of work and creativity, and prepare himself/herself to engage in honest and gainful work.

\section{Kindergarten Education}

3. As defined in the Enhanced Basic Education Act of 2013, Kindergarten is the first stage of compulsory and mandatory formal education, which consists of one (1) year of preparatory education for children at least five (5) years old as a prerequisite for Grade 1.

\section{Elementary Education}

4. The Enhanced Basic Education Act of 2013 also articulates that elementary education refers to the second stage of compulsory basic education, which consists of six (6) years. The entrance age to this level is typically six (6) years old, which is the age requirement for Grade 1.

5. Elementary education is specifically represented by elementary grades. Elementary grades refer to the grade levels in the elementary from Grade 1 to Grade 6 . These are composed of two key stages of the $\mathrm{K}$ to 12 Curriculum, namely, Key Stage 1 (Kindergarten to Grade 3) and Key Stage 2 (Grades 4-6). The learners in the elementary grades are generally from six (6) years old to twelve (12) years old.

6. The main purpose of elementary education is to help learners develop a solid base of literacy, numeracy, social and inquiry skills that will provide a strong foundation for lifelong learning. The outcomes are intended to engage them in rich, vibrant, culture-based and meaningful experiences in which they develop understanding that both relate to and make connections across specific learning areas. 


\section{Characteristics of Learners in the Elementary School}

7. To provide context to the educational goals of elementary education, it is necessary to have a basic understanding of the developmental characteristics and expectations of young learners. The nature and characteristics of learners are the primary considerations in shaping the $\mathrm{K}$ to 12 curriculum.

\section{A. Early Childhood (Age 0 to 8)}

8. Early childhood is a critical period in the formation of the child's intelligence, personality, and social behavior. From age 0 to 4 years old, children are developing quickly in all aspects of development, namely, physical, cognitive, socialemotional, and language development.

9. From 5 to 8 years old, children's physical growth slows down a little, but great strides in gross and fine motor coordination take place. Their organ systems (muscular, skeletal, nervous, respiratory, circulatory, and immune systems) are maturing, thus it is important that their health and nutritional needs are met.

10. Cognitively, children's speech and language abilities develop, allowing them to increasingly use language and symbols to learn more about the world around them. They use speech to communicate with others (social speech) and to gain control over their own actions (private speech). Children at this stage use symbols that allow them to think creatively and slowly as they are learning to process information logically. They can be easily frightened by new or strange events, as they sometimes get carried away by their imaginations in the process of learning to distinguish fantasy from reality.

11. As they develop the ability to take perspectives different from their own, children move from being egocentric to having a stronger sense of others. They also develop the capacity to share and take turns, and they are able to play cooperatively with their peers. Play is an important avenue for learning and development at this age. It develops social skills and enhances cognitive ability as it improves creativity and symbolic thinking.

12. At this age, children are also learning their identities. They learn what is expected of them by observing and imitating models, who are usually their parents, but can also be other significant people like older siblings, teachers, or peers.

13. The National Early Learning Framework (NELF) developed by the Early Childhood Care and Development Council (ECCD) in 2010 provides 16 principles that can serve as guide to the understanding of the young learners. These are categorized according to child growth and development, learning and development programs, and assessment of learning. Below are 15 of the Principles of Early Childhood Education (ECCD Council, 2010) that we find relevant for Elementary Education:

\section{On Child Growth and Development}

a. Every child is unique. Growth and development vary from child to child, for whom the first six years of life are most vital. He/she has an innate desire to learn, and this is best done through meaningful and real experiences. 
b. Every aspect of growth and development is interrelated and interdependent. The child needs to be nurtured in a good and caring environment that enhances healthy and dependable relationships with other children and most significant adults.

c. The learning and development of every child involve a series of complex and dynamic processes that are best attended to in a positive and responsive manner.

d. The child must be encouraged to aim beyond one's own level of achievements and to practice newly acquired competencies.

e. Every child is a thinking, moving, feeling human being able to actively participate in the learning and development of self in the context of one's family and community, including cultural and religious beliefs.

\section{On Learning Program Development}

a. The learning program is child-centered. Children are engaged as active learners through play, the context for early learning and development. It promotes the holistic way by which young children grow and develop, and recognizes the role of families and communities in supporting the child through various stages of growth and development.

b. The learning program is appropriate for developing the domains, and must sustain interest in active learning of all young children including those with special abilities, in marginalized situations, and/or those at risk.

c. The learning program is implemented by way of diverse learning activities that may be enhanced with multimedia technologies such as interactive radio, audio and/or video clips, and computer-enhanced activities.

d. The use of locally developed and/or locally available learning materials and other resources is encouraged.

e. Mother tongue shall be used as the child's language of learning in the early years and shall be recognized as a bridge language of learning.

\section{On Learning Assessment}

a. Assessment monitors learning and ascertains where the child is atvital information that would advise teachers and parents of the child's progress.

b. Assessment is crucial to identifying the child's total developmental needs and does not determine academic achievement.

c. Assessment is best conducted on a regular basis so that timely response or intervention can be made to improve learning.

d. Ratings should also be qualitative and descriptive and not only numerical.

e. The family and community may be informed of the general outcomes of learning so as to encourage further cooperation and partnerships.

\section{B. Middle Childhood (Ages 9 to 12)}

14. Children in middle childhood become increasingly more coordinated and integrative in their motor and perceptual skills resulting in increased physical coordination and strength. Their small muscles develop rapidly, making playing instruments, hammering, or building things more enjoyable. Manual dexterity also 
develops, and children become better at cutting, coloring, drawing, and similar activities. Physical activity (e.g. sports, outdoor play) is important to help children continue to develop their gross motor skills as well as improve their overall health and fitness.

15. Children's ability to learn grows substantially at this age because of their increasing capacity to think conceptually, solve problems, and use language. At this age, children should have acquired the ability to read, write, compose, compute, inquire, and work with others. They can now use these skills and abilities as tools for learning. They are able to think more logically and make mental representations of objects and events. As in early childhood, children still learn best through active engagement. For example, children will learn more effectively about road safety by moving cars, blocks, and toy figures rather than sitting and listening to an adult explain the rules. Their capacity to remember (memory) also improves greatly by middle childhood, and this helps them learn even more.

16. Children's self-concept (how they see themselves) at this age is influenced in large part by their physical, intellectual, and social skills. Positive selfesteem develops when children see themselves as competent and able to master the skills they consider important in their lives. A positive self-concept, in turn, impacts greatly on their personality development. Children who like themselves tend to be happier and more confident, and vice versa. At this age, children are also spending more and more time with their peers, rather than with their parents or families. Through spending time and interacting with peers, children develop their social skills and sense of belonging. They also become more motivated to achieve and learn. Cooperative learning tasks are thus suitable vehicles for learning at this stage of development. Guidance on developing friendships and how to influence others positively promote their socio-emotional development.

\section{Key Stage 1: Kindergarten to Grade 3}

17. Beginning at an early age, learners must be cared for and provided with all opportunities to address their developmental needs for lifelong learning. To contribute to fulfilling the goals of elementary education, the Kindergarten to Grade 3 curriculum aims to:

a. Provide learners with opportunities to engage in meaningful and culture-based learning experiences, and provide learners access to carefully selected and developmentally appropriate learning materials and resources;

b. Introduce learners to:

i. The sense of self and community

ii. Concepts and ideas in the different learning areas

iii. A positive attitude towards learning; and

c. Equip learners with fundamental literacy and numeracy skills, and competencies needed for academic success in the later key stages.

18. As such, the following programs are implemented within the first key stage of the $\mathrm{K}$ to 12 Basic Education Program to enable young learners to develop and learn. 


\section{A. The Kindergarten Education Program}

19. The Kindergarten Education (KE) is a basic education program which aims for all five-year-old children to achieve the standards and competencies expected of them, taking into account their diverse backgrounds, prior knowledge experiences, skills, attitudes, personal traits, and interests.

20. The KE Program aims to contribute positively to the development of young children by providing them with more structured learning experiences to effectively promote their physical, social, cultural, emotional, and intellectual development, including values formation, to sufficiently prepare them for further schooling.

21. Achievement of universal Kindergarten or provision of $\mathrm{KE}$ to all will increase young learners' chance of completing formal schooling, reduce incidence of school leavers, and ensure better school performance (DO 47, s. 2016).

\section{Curriculum}

22. The Kindergarten curriculum has been designed to integrate developmentally appropriate content and pedagogies that are consistent with the way children think, learn, and relate with others. Fundamental skills development, content integration, and play are key features of the curriculum and its delivery mechanisms.

23. Following the Mother Tongue-Based Multilingual Education (MTBMLE) Program, the use of the learner's mother tongue as medium of teaching and learning is among the most distinct features of the Kindergarten curriculum and Key Stage 1 onwards to Grades 1 to 3 .

24. The following are key features of the MTB-MLE Program:

a. Acknowledges and cultivates what the learners already know, and builds on the learner's prior knowledge to move to new knowledge.

b. Builds a strong foundation for literacy in the learner's first language, which becomes a good bridge to learning other languages.

c. Uses locally relevant or culturally familiar concepts to help learners understand concepts prescribed in the curriculum.

d. Emphasizes understanding, meaning, and communication as well as skill development (Dekker, 2001).

25. Details of the MTB-MLE Program, including the Language Transition Program, will be discussed further in the MTB-MLE policy to be issued.

26. The Kindergarten curriculum is represented through the Kindergarten Curriculum Guide (KCG), which articulates the standards and competencies appropriate for five (5)-year-old Filipino learners. The KCG is the basis for daily activities spelled out in the Teacher's Guide. 


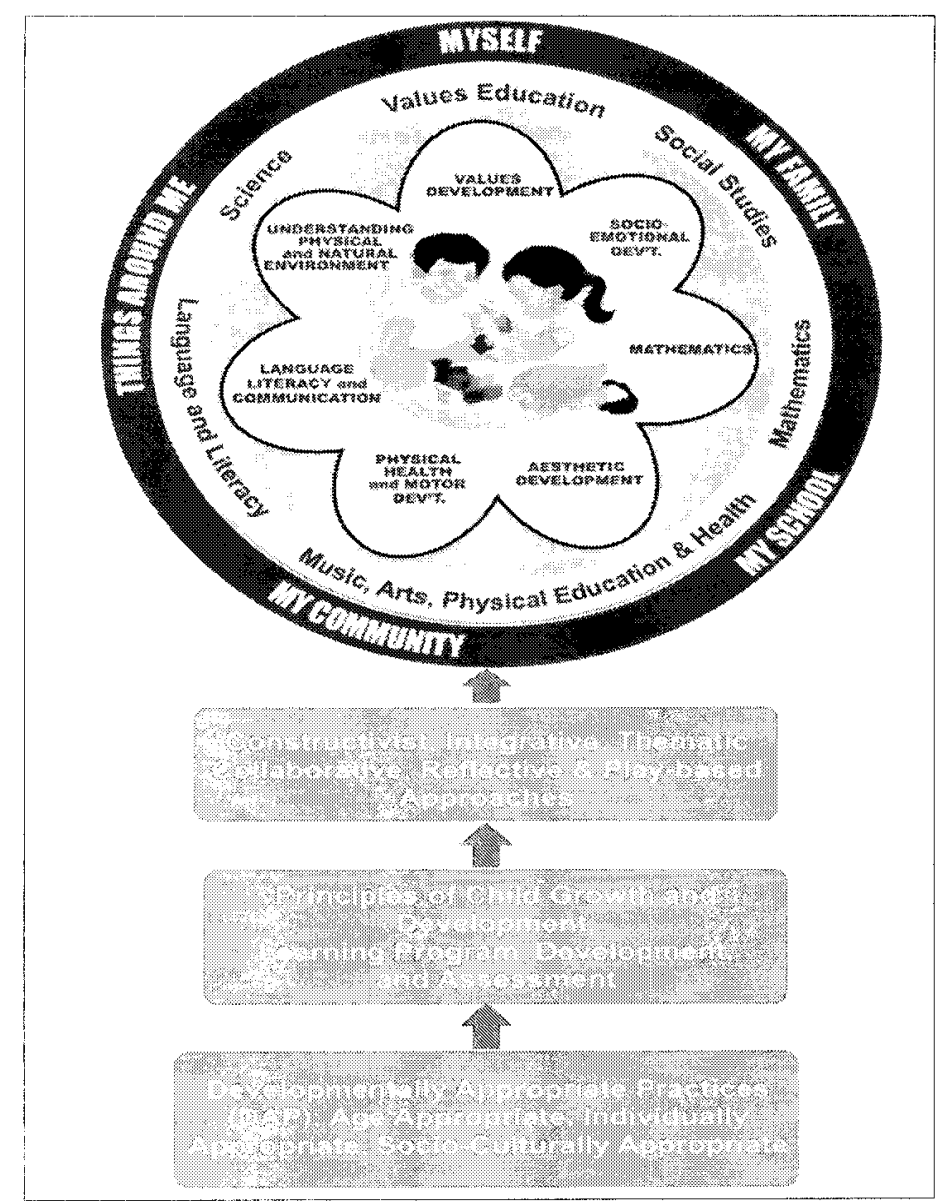

Figure 1.1: Kindergarten Curriculum Framework

27. Figure 1.1 illustrates the Kindergarten Curriculum Framework. The items in rectangles show the theoretical bases for teaching-learning in the early years, which are founded on constructivism, integrative, thematic, collaborative, inquiry-based, and reflective teaching in play-based approaches with application of Developmentally Appropriate Practices (DAP). These support the principles of child growth and development, and the learning program development and assessment.

28. The circles, on the other hand, signify the system of how Kindergarten Education is to be employed. The interlocked ellipses represent the learning domains that must be nurtured and equally imparted to holistically develop children. It also forms a flower that portrays the gradual unfolding but steady development that is expected of every child. The child is seen as being in the process of blossoming - like a flower bud whose development should not be forced lest it lose its chance to fully mature. The domains are enclosed by the Learning Areas children will meet in Grade 1 onward, for which they are being prepared. The outermost layer indicates the Curricular Themes upon which the Teacher's Guide is designed.

\section{Instruction}

29. Many opportunities for play and active involvement in concrete and meaningful experiences are provided in Kindergarten. Play is essential to healthy and holistic child development, as it gives children opportunities to learn about and understand their world and practice newly acquired skills. Play is also essential in building children's self-confidence, problem-solving, and cooperative learning skills 
that prepare them for lifelong learning. The varied play-based activities in Kindergarten lead the learners to becoming emergent literates, and help them to naturally acquire the competencies to develop holistically. This also leads them to become willing risk takers, and ready to tackle formal school work (DO 47, s. 2016).

30. In the Kindergarten curriculum, the following domains are developed holistically:
a. Socio-emotional Development
b. Values Development
c. Physical Health and Motor Development
d. Aesthetic/Creative Development
e. Mathematics
f. Understanding of the Physical and Natural Environment
g. Language, Literacy, and Communication

31. When progress is noted in one developmental domain, it will consequently impact other domains. The contents of the developmental domain are defined by learning expectations.

Table 1.1: Kindergarten Time Allotment

\begin{tabular}{|l|l|}
\hline \multicolumn{1}{|c|}{$\begin{array}{c}\text { Kinder Daily Activities } \\
\text { (Blocks of time) }\end{array}$} & \multicolumn{1}{c|}{$\begin{array}{c}\text { Time Allotment } \\
\text { No. of minutes daily }\end{array}$} \\
\hline Arrival time & 10 \\
\hline Meeting Time 1 & 10 \\
\hline Work Period 1 & 45 \\
\hline Meeting Time 2 & 10 \\
\hline Recess & 15 \\
\hline Quiet Time & 10 \\
\hline Stories/ Rhymes/ Poems/ Songs & 15 \\
\hline Work Period 2 & 40 \\
\hline Indoor/Outdoor Games & 20 \\
\hline Meeting Time 3 & 5 \\
\hline Total Time (in minutes) & 180 \\
\hline Total Time (in hours) & 3 \\
\hline
\end{tabular}

32. Kindergarten follows a class program known as the Blocks of Time. Following the daily routine helps children feel safe while supporting and encouraging them to take risks and work cooperatively with others. Table 1.1 outlines an indicative schedule, description of activities, and sample competencies that can be developed in each block of time. The Kindergarten teacher may be flexible in the use of class time to meet learning objectives for a day and to give children ample time to explore and discover what they can do. In addition to the daily activities in Table 1.1 however, two thirty-minute sessions should be allotted per week for Homeroom. See Annex 11 for program details on the Homeroom Guidance Program Policy for program details.

\section{B. The Grades 1 to 3 Program}

33. The Grades 1 to 3 Program serves as a springboard for formal schooling. This is where learners are initially exposed to learning areas taught in separate 
blocks of time. The learners in Grade 1 are generally six (6) years old, while those in Grade 2 are seven (7) years old. Grade 3 learners are usually eight (8) years old.

\section{Learning Areas under the Grades 1 to 3 Program}

34. In Grades 1 and 2, there are seven (7) learning areas, namely, Mother Tongue; Filipino; English; Mathematics; Araling Panlipunan; Music, Art, Physical Education and Health (MAPEH); and Edukasyon sa Pagpapakatao (EsP). In Grades 1 and 2, Science is not included. The learning areas in Grade 3 are the same as the learning areas in Grades 1 and 2; however, in Grade 3, Science is already included as a separate learning area. Though Science is not taught as a separate learning area in Grades 1 and 2, Science concepts are integrated in the other learning areas.

35. All learning areas have a Curriculum Guide (CG) with program standards, learning area standards, course description, and key stage standards from Grades 1 to 3 . Additionally, the CGs also articulate grade level standards and content standards and performance standards for each quarter.

36. The curriculum guide for the learning areas is anchored on a conceptual framework for the teaching of the subject found in the curriculum guides. Each conceptual framework contains the goals of teaching the subject, and the teaching methods and approaches. This is presented with a schematic diagram and an accompanying write-up in the curriculum guides for each learning area. Table 1.2 provides a summary description of each learning area in Grades 1 to 3:

Table 1.2: Grades 1 to 3 Curriculum

\begin{tabular}{|c|c|c|c|}
\hline \multicolumn{4}{|c|}{ Grades 1 to 3 Curriculum } \\
\hline Grade Level & Grade 1 & Grade 2 & Grade 3 \\
\hline $\begin{array}{c}\text { Learning } \\
\text { Area }\end{array}$ & \multicolumn{3}{|c|}{ Description } \\
\hline $\begin{array}{l}\text { Mother } \\
\text { Tongue }\end{array}$ & $\begin{array}{l}\text { This subject covers } \\
\text { basic communication } \\
\text { skills. Learners are } \\
\text { able to talk about } \\
\text { familiar topics using } \\
\text { simple words, use } \\
\text { both verbal and } \\
\text { nonverbal cues to } \\
\text { understand spoken } \\
\text { language, basic } \\
\text { understand and } \\
\text { vocabulary ary } \\
\text { language structures, } \\
\text { the reading process } \\
\text { and the writing } \\
\text { system, and } \\
\text { appreciate aspects of } \\
\text { one's culture. }\end{array}$ & $\begin{array}{l}\text { This subject covers the } \\
\text { further development of } \\
\text { communication skills. } \\
\text { Learners are able to talk } \\
\text { about a variety of topics } \\
\text { using developing } \\
\text { vocabulary and simple } \\
\text { phrases and sentences, } \\
\text { understand simple to } \\
\text { complex spoken } \\
\text { language using both } \\
\text { verbal and nonverbal } \\
\text { cues, understand } \\
\text { vocabulary and } \\
\text { language structures, } \\
\text { appreciate and } \\
\text { understand the cultural } \\
\text { aspects of the language } \\
\text { and the writing system }\end{array}$ & $\begin{array}{l}\text { The subject covers the } \\
\text { further development of } \\
\text { communication skills. } \\
\text { Learners are able to } \\
\text { talk about a variety of } \\
\text { topics using expanding } \\
\text { vocabulary and } \\
\text { phrases, show } \\
\text { understanding of } \\
\text { spoken language in } \\
\text { different contexts using } \\
\text { both verbal and } \\
\text { nonverbal cues, } \\
\text { understand vocabulary } \\
\text { and language } \\
\text { structures and cultural } \\
\text { aspects of the } \\
\text { language, and read and }\end{array}$ \\
\hline
\end{tabular}




\begin{tabular}{|c|c|c|c|}
\hline \multicolumn{4}{|c|}{ Grades 1 to 3 Curriculum } \\
\hline Grade Level & Grade 1 & Grade 2 & Grade 3 \\
\hline $\begin{array}{c}\text { Learning } \\
\text { Area }\end{array}$ & \multicolumn{3}{|c|}{ Description } \\
\hline & & $\begin{array}{l}\text { used, and reads and } \\
\text { writes simple and short } \\
\text { literary and } \\
\text { informational texts. }\end{array}$ & $\begin{array}{l}\text { write literary and } \\
\text { informational texts. }\end{array}$ \\
\hline Filipino & $\begin{array}{l}\text { This subject covers: } \\
\text { pasalita at di- } \\
\text { pasalitang paraan ng } \\
\text { pagpapahayag, } \\
\text { pagtugon nang } \\
\text { naaayon, at } \\
\text { mabuting pagbasa at } \\
\text { pagsulat upang } \\
\text { maipahayag at } \\
\text { maiugnay ang } \\
\text { sariling ideya, } \\
\text { damdamin at } \\
\text { karanasan sa mga } \\
\text { narinig at nabasang } \\
\text { mga teksto ayon sa } \\
\text { kanilang antas o } \\
\text { lebel at kaugnay ng } \\
\text { kanilang kultura. }\end{array}$ & $\begin{array}{l}\text { This subject covers: } \\
\text { pangunahing diwa ng } \\
\text { tekstong binasa o } \\
\text { napakinggan, paggamit } \\
\text { ng mga kaalaman sa } \\
\text { wika, pagbasa nang } \\
\text { may wastong paglilipon } \\
\text { ng mga salita, maayos } \\
\text { na pagsulat upang } \\
\text { maipahayag at } \\
\text { maiugnay ang sariling } \\
\text { ideya, damdamin at } \\
\text { karanasan sa mga } \\
\text { narinig at nabasang } \\
\text { mga teksto ayon sa } \\
\text { kanilang antas o lebel } \\
\text { at kaugnay ng kanilang } \\
\text { kultura. }\end{array}$ & $\begin{array}{l}\text { This subject covers: } \\
\text { pangunahing diwa ng } \\
\text { tekstong binasa o } \\
\text { napakinggan, } \\
\text { pagbibigay ng kaugnay } \\
\text { o katumbas na teksto, } \\
\text { paggamit ng mga } \\
\text { kaalaman sa wika, } \\
\text { pagbasa nang may } \\
\text { wastong palipon ng } \\
\text { mga salita at maayos } \\
\text { na nakasulat gamit } \\
\text { ang iba't ibang bahagi } \\
\text { ng pananalita upang } \\
\text { maipahayag at } \\
\text { maiugnay ang sariling } \\
\text { ideya, damdamin at } \\
\text { karanasan sa mga } \\
\text { narinig at nabasang } \\
\text { mga teksto ayon sa } \\
\text { kanilang antas o lebel } \\
\text { at kaugnay ng } \\
\text { kanilang kultura. }\end{array}$ \\
\hline English & $\begin{array}{l}\text { The subject covers } \\
\text { listening for } \\
\text { comprehension, } \\
\text { speaking clearly, and } \\
\text { use of appropriate } \\
\text { expressions in } \\
\text { talking about oneself, } \\
\text { family, and other } \\
\text { social context } \\
\text { interactions. }\end{array}$ & $\begin{array}{l}\text { The subject covers } \\
\text { listening critically to } \\
\text { one-two paragraphs; } \\
\text { the use of appropriate } \\
\text { expressions in varied } \\
\text { situations; reading of } \\
\text { texts for pleasure and } \\
\text { information critically in } \\
\text { meaningful thought } \\
\text { units; responding } \\
\text { properly to } \\
\text { environmental prints } \\
\text { likes signs, posters, } \\
\text { commands, and } \\
\text { requests; and writing } \\
\text { legibly simple sentences } \\
\text { and messages in cursive } \\
\text { form. }\end{array}$ & $\begin{array}{l}\text { The subject covers } \\
\text { listening critically to } \\
\text { get information from } \\
\text { text heard, } \\
\text { independence in using } \\
\text { the basic language } \\
\text { structure in oral and } \\
\text { written } \\
\text { communication, and } \\
\text { reading with } \\
\text { comprehension. }\end{array}$ \\
\hline
\end{tabular}




\begin{tabular}{|c|c|c|c|}
\hline \multicolumn{4}{|c|}{ Grades 1 to 3 Curriculum } \\
\hline Grade Level & Grade 1 & Grade 2 & Grade 3 \\
\hline $\begin{array}{c}\text { Learning } \\
\text { Area }\end{array}$ & \multicolumn{3}{|c|}{ Description } \\
\hline Science & $\begin{array}{l}\text { The subject focuses } \\
\text { on the use of senses } \\
\text { to locate and describe } \\
\text { the external parts of } \\
\text { their body; to identify } \\
\text { external parts of } \\
\text { animals and plants; } \\
\text { to tell the shape, } \\
\text { color, texture, taste, } \\
\text { and size of things } \\
\text { around them; to } \\
\text { describe similarities } \\
\text { and differences given } \\
\text { two objects; to } \\
\text { differentiate sounds } \\
\text { produced by animals, } \\
\text { vehicles, and musical } \\
\text { instruments; to } \\
\text { illustrate how things } \\
\text { move; to describe the } \\
\text { weather and what to } \\
\text { do in different } \\
\text { situations; to use } \\
\text { appropriate terms or } \\
\text { vocabulary to to } \\
\text { describe the } \\
\text { features; to collect, } \\
\text { sort, count, draw, } \\
\text { take things apart, or } \\
\text { make something out } \\
\text { of the things; to } \\
\text { practice healthy } \\
\text { habits (e.g. washing } \\
\text { hands properly, } \\
\text { choosing nutritious } \\
\text { food) and safety } \\
\text { measures (e.g. } \\
\text { helping to clean or } \\
\text { pack away toys, } \\
\text { asking questions and } \\
\text { giving simple } \\
\text { answers/ } \\
\text { descriptions thestions). } \\
\text { probing questions }\end{array}$ & $\begin{array}{l}\text { The subject focuses on } \\
\text { the use of senses to } \\
\text { explore, describe the } \\
\text { functions of their } \\
\text { senses; compare two or } \\
\text { more objects using two } \\
\text { or more properties; sort } \\
\text { things in different ways } \\
\text { and give a reason for } \\
\text { doing so; describe the } \\
\text { kind of weather or } \\
\text { certain events in the } \\
\text { home or school and } \\
\text { express how these are } \\
\text { affecting them; do } \\
\text { simple measurements } \\
\text { of length, tell why some } \\
\text { things around them are } \\
\text { important; decide if } \\
\text { what they do is safe or } \\
\text { dangerous; give } \\
\text { suggestions on how to } \\
\text { prevent accidents at } \\
\text { home; practice } \\
\text { electricity, water, and } \\
\text { paper conservation; } \\
\text { help take care of pets or } \\
\text { of plants; and tell short } \\
\text { stories about what they } \\
\text { do, what they have } \\
\text { seen, or what they feel. }\end{array}$ & $\begin{array}{l}\text { The subject focuses on } \\
\text { the functions of the } \\
\text { different parts of the } \\
\text { body and things that } \\
\text { make up their } \\
\text { surroundings-rocks } \\
\text { and soil, plants and } \\
\text { animals, the Sun, } \\
\text { Moon, and the stars. } \\
\text { The focus is also on the } \\
\text { classification of things } \\
\text { as solid, liquid, or gas, } \\
\text { how objects move and } \\
\text { what makes them } \\
\text { move, sources and } \\
\text { uses of light, heat, } \\
\text { sound, and electricity, } \\
\text { and changes in the } \\
\text { conditions of their } \\
\text { surroundings. These } \\
\text { would lead learners to } \\
\text { become more curious } \\
\text { about their } \\
\text { surroundings, apreciate nature, and } \\
\text { appreactice health and } \\
\text { praction measures. } \\
\text { safety meat }\end{array}$ \\
\hline
\end{tabular}




\begin{tabular}{|c|c|c|c|}
\hline \multicolumn{4}{|c|}{ Grades 1 to 3 Curriculum } \\
\hline Grade Level & Grade 1 & Grade 2 & Grade 3 \\
\hline $\begin{array}{l}\text { Learning } \\
\text { Area }\end{array}$ & \multicolumn{3}{|c|}{ Description } \\
\hline Math & 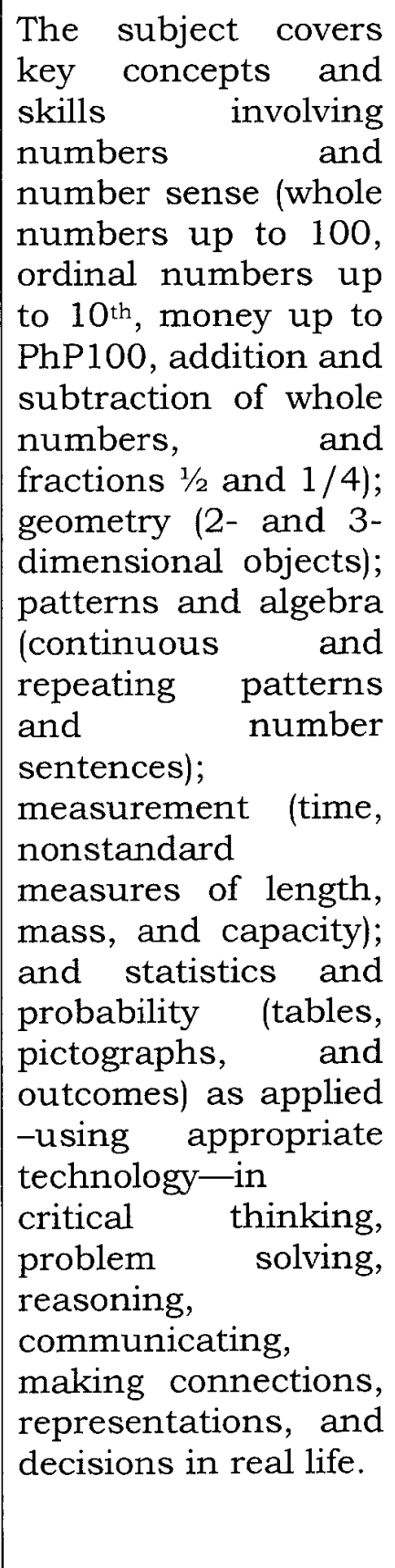 & $\begin{array}{l}\text { The subject covers key } \\
\text { concepts and skills } \\
\text { involving numbers and } \\
\text { number sense (whole } \\
\text { numbers up to } 1 \text { ooo, } \\
\text { ordinal numbers up to } \\
\text { 20th, money up to } \\
\text { PhP100, the four } \\
\text { fundamental operations } \\
\text { of whole numbers, and } \\
\text { unit fractions); } \\
\text { geometry (basic shapes, } \\
\text { symmetry, and } \\
\text { tessellations); patterns } \\
\text { and algebra (continuous } \\
\text { and repeating patterns } \\
\text { and number } \\
\text { sentences);measuremen } \\
\text { (time, length, mass, } \\
\text { and capacity); and } \\
\text { statistics and } \\
\text { probability (tables, } \\
\text { pictographs, and } \\
\text { outcomes) as applied- } \\
\text { using appropriate } \\
\text { technology-in critical } \\
\text { thinking, problem } \\
\text { solving, reasoning, } \\
\text { communicating, ang, and } \\
\text { making connections, } \\
\text { representations, and } \\
\text { decisions in real life. }\end{array}$ & 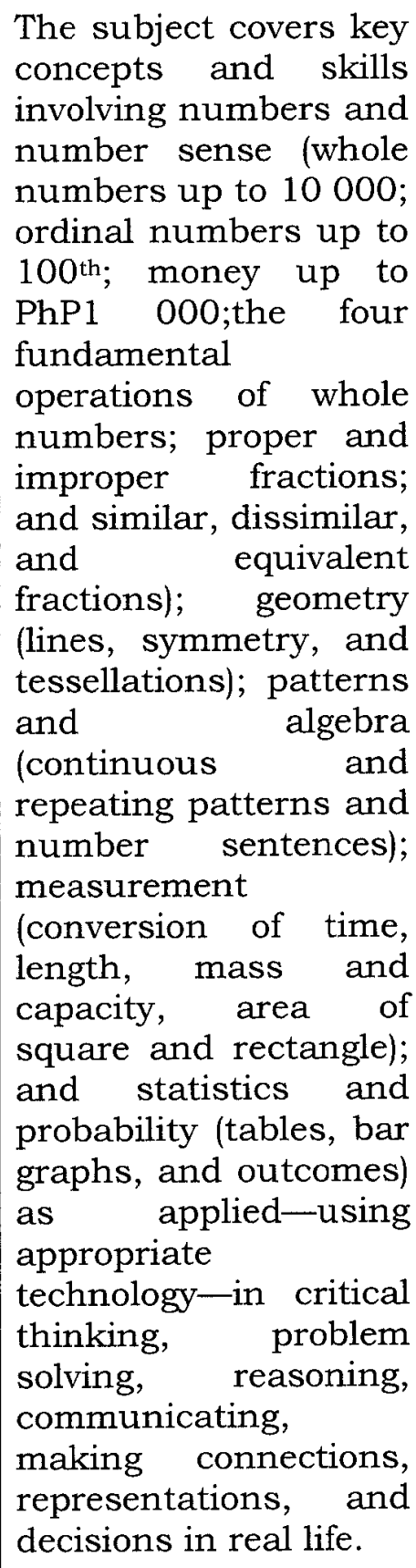 \\
\hline AP & $\begin{array}{l}\text { The subject covers } \\
\text { the following: } \\
\text { kamalayan at pag- } \\
\text { unawa sa sarili } \\
\text { bilang kasapi ng } \\
\text { pamilya at paaralan } \\
\text { at pagpapahalaga sa }\end{array}$ & $\begin{array}{l}\text { The subject covers: } \\
\text { kamalayan, pag-unawa } \\
\text { at pagpapahalaga sa } \\
\text { kasalukuyan } \\
\text { nakaraan } \\
\text { kinabibilangang } \\
\text { komunidad, gamit ang }\end{array}$ & $\begin{array}{l}\text { The subject covers: } \\
\text { malawak na pag- } \\
\text { unawa at } \\
\text { pagpapahalaga ng mga } \\
\text { komunidad ng Pilipinas } \\
\text { bilang bahagi ng mga } \\
\text { lalawigan at rehiyon ng }\end{array}$ \\
\hline
\end{tabular}




\begin{tabular}{|c|c|c|c|}
\hline \multicolumn{4}{|c|}{ Grades 1 to 3 Curriculum } \\
\hline Grade Level & Grade 1 & Grade 2 & Grade 3 \\
\hline $\begin{array}{c}\text { Learning } \\
\text { Area }\end{array}$ & \multicolumn{3}{|c|}{ Description } \\
\hline & $\begin{array}{lr}\text { kapaligirang pisikal } \\
\text { gamit ang konsepto } \\
\text { ng pagpapatuloy at } \\
\text { pagbabago, } & \\
\text { interaksyon, } & \\
\text { distansya r at } \\
\text { direksyon tungo sa } \\
\text { pagkakakilanlan } & \\
\text { bilang indibidwal at } \\
\text { kasaping pangkat } n g \\
\text { lipunan } & \text { at } \\
\text { komunidad. } & \end{array}$ & $\begin{array}{lr}\text { konsepto } & \text { ng } \\
\text { pagpapatuloy } & \\
\text { pagbabago, } & \\
\text { kapangyarihan, } \\
\text { pamumuno at } \\
\text { pananagutan, } \\
\text { pangangailangan at } \\
\text { kagustuhan, } \\
\text { pagkakilanlan, mga } \\
\text { simpleng konseptong } \\
\text { heograpikal tulad ng } \\
\text { lokasyon at } \\
\text { pinagkukunang-yaman } \\
\text { at ng mga saksi ng } \\
\text { kasaysayan tulad ng } \\
\text { tradisyong oral at mga } \\
\text { labingkasaysayan. }\end{array}$ & $\begin{array}{lr}\text { bansa batay sa (a) } \\
\text { katangiang pisikal, (b) } \\
\text { kultura, (c) kabuhayan, } \\
\text { at (d) pulitikal, gamit } \\
\text { ang malalim na } \\
\text { konsepto ng } \\
\text { pagpapatuloy } \\
\text { pagbabago, } \\
\text { interaksyon ng tao at } \\
\text { kapaligirang pisikal at } \\
\text { sosyal. }\end{array}$ \\
\hline Music & $\begin{array}{l}\text { The subject covers } \\
\text { the fundamental } \\
\text { processes in music } \\
\text { and art, through } \\
\text { performing, creating, } \\
\text { listening and } \\
\text { observing, and } \\
\text { responding. }\end{array}$ & $\begin{array}{l}\text { The subject covers the } \\
\text { basic and fundamental } \\
\text { processes in music and } \\
\text { art, through } \\
\text { performing, creating, } \\
\text { listening and observing, } \\
\text { and responding. }\end{array}$ & $\begin{array}{l}\text { The subject covers the } \\
\text { basic and fundamental } \\
\text { processes through } \\
\text { performing, creating, } \\
\text { listening and } \\
\text { observing, and } \\
\text { responding, toward the } \\
\text { development of } \\
\text { appreciation of music } \\
\text { and art, and the } \\
\text { acquisition of basic } \\
\text { knowledge and skills. }\end{array}$ \\
\hline Arts & $\begin{array}{l}\text { The subject covers } \\
\text { the fundamental } \\
\text { processes in music } \\
\text { and art, through } \\
\text { performing, creating, } \\
\text { listening and } \\
\text { observing, and } \\
\text { responding. }\end{array}$ & $\begin{array}{l}\text { The subject covers basic } \\
\text { and fundamental } \\
\text { processes in music and } \\
\text { art, through } \\
\text { performing, creating, } \\
\text { listening and observing, } \\
\text { and responding. }\end{array}$ & $\begin{array}{l}\text { The subject covers } \\
\text { basic and fundamental } \\
\text { processes through } \\
\text { performing, creating, } \\
\text { listening and } \\
\text { observing, and } \\
\text { responding, toward the } \\
\text { development of } \\
\text { appreciation of music } \\
\text { and art, and the } \\
\text { acquisition of basic } \\
\text { knowledge and skills. }\end{array}$ \\
\hline $\begin{array}{l}\text { Physical } \\
\text { Education }\end{array}$ & $\begin{array}{l}\text { The subject covers } \\
\text { singing games, action } \\
\text { songs, simple games, }\end{array}$ & $\begin{array}{l}\text { The subject covers } \\
\text { activities in different } \\
\text { locomotor, }\end{array}$ & $\begin{array}{l}\text { The subject covers } \\
\text { challenging activities in } \\
\text { different locomotor, }\end{array}$ \\
\hline
\end{tabular}




\begin{tabular}{|c|c|c|c|}
\hline \multicolumn{4}{|c|}{ Grades 1 to 3 Curriculum } \\
\hline Grade Level & Grade 1 & Grade 2 & Grade 3 \\
\hline $\begin{array}{c}\text { Learning } \\
\text { Area }\end{array}$ & \multicolumn{3}{|c|}{ Description } \\
\hline & $\begin{array}{l}\text { particularly } \\
\text { chasing/fleeing-type } \\
\text { games and mimetics. }\end{array}$ & $\begin{array}{l}\text { locomotor and } \\
\text { manipulative activities, } \\
\text { folk dances, rhythmic } \\
\text { routines (ribbon, hoop, } \\
\text { balls, } \\
\text { indigenous/improvised } \\
\text { materials), relays, and } \\
\text { races. }\end{array}$ & $\begin{array}{l}\text { non-locomotor and } \\
\text { manipulative activities, } \\
\text { simple folk dance, } \\
\text { rhythmic routines } \\
\text { (ribbon, hoop, balls, } \\
\text { etc.), lead-up and } \\
\text { organized games } \\
\text { (indigenous), and } \\
\text { corrective exercises. }\end{array}$ \\
\hline Health & $\begin{array}{l}\text { The subject covers } \\
\text { the essential } \\
\text { concepts related to } \\
\text { nutrition and } \\
\text { personal health as } \\
\text { well as knowledge in } \\
\text { injury-prevention, } \\
\text { safety and first aid, } \\
\text { as factors in } \\
\text { facilitating the } \\
\text { development of } \\
\text { healthy habits and } \\
\text { practices among } \\
\text { individuals. }\end{array}$ & $\begin{array}{l}\text { The subject covers } \\
\text { personal health; family } \\
\text { health; the prevention } \\
\text { and control of diseases } \\
\text { and disorders; as well } \\
\text { as injury prevention, } \\
\text { safety and first aid, } \\
\text { which are factors that } \\
\text { facilitate the } \\
\text { development of healthy } \\
\text { habits and practices. }\end{array}$ & $\begin{array}{l}\text { The subject covers } \\
\text { nutrition; prevention } \\
\text { and control of diseases } \\
\text { and disorders; } \\
\text { consumer health; and } \\
\text { community and } \\
\text { environmental } \\
\text { health-factors that } \\
\text { facilitate the } \\
\text { development of healthy } \\
\text { habits and practices. }\end{array}$ \\
\hline $\begin{array}{l}\text { Edukasyon sa } \\
\text { Pagpapakatao }\end{array}$ & $\begin{array}{l}\text { The subject covers: } \\
\text { pag-unawa sa mga } \\
\text { paraan ng paggalang } \\
\text { sa sarili, kapwa, } \\
\text { bansa at Diyos bilang } \\
\text { gabay tungo sa } \\
\text { maayos at masayang } \\
\text { tahanan at paaralan. }\end{array}$ & $\begin{array}{l}\text { The subject covers: } \\
\text { pag-unawa sa } \\
\text { pagpapakikita ng mga } \\
\text { kilos na nagpapahalaga } \\
\text { sa sarili, kapwa, bansa, } \\
\text { Diyos at sa Kanyang } \\
\text { mga nilikha bilang } \\
\text { patnubay sa maayos at } \\
\text { masayang paaralan at } \\
\text { pamayanan. }\end{array}$ & $\begin{array}{l}\text { The subject covers: } \\
\text { pag-unawa sa mga } \\
\text { gawain na nagpapakita } \\
\text { ng pagpapahalaga } \\
\text { tungo sa maayos at } \\
\text { masayang pamumuhay } \\
\text { na may mapanagutang } \\
\text { pagkilos at } \\
\text { pagpapasiya para sa } \\
\text { sarili, kapwa, } \\
\text { pamayanan, bansa, at } \\
\text { Diyos. }\end{array}$ \\
\hline
\end{tabular}

37. Table 1.3 below shows the time allotment for Grades 1 to 3 . 
Table 1.3: Time Allotment for Grades 1 to 3

\begin{tabular}{|c|c|c|c|c|}
\hline \multirow{4}{*}{ LEARNING AREA } & \multirow{2}{*}{\multicolumn{4}{|c|}{$\begin{array}{l}\text { TIME ALLOTMENT } \\
\text { Number of Minutes Daily }\end{array}$}} \\
\hline & & & & \\
\hline & \multicolumn{2}{|c|}{ G1 } & \multirow[b]{2}{*}{ G2 } & \multirow[b]{2}{*}{ G3 } \\
\hline & $\begin{array}{c}\text { 1st } \\
\text { Semester }\end{array}$ & $\begin{array}{c}\text { 2nd } \\
\text { Semester }\end{array}$ & & \\
\hline Mother Tongue & 50 & 50 & 50 & 50 \\
\hline Filipino & 30 & 30 & 50 & 50 \\
\hline English & - & 30 & 50 & 50 \\
\hline Science & - & - & - & 50 \\
\hline Mathematics & 50 & 50 & 50 & 50 \\
\hline Araling Panlipunan & 40 & 40 & 40 & 40 \\
\hline MAPEH & 40 & 40 & 40 & 40 \\
\hline $\mathrm{EsP}$ & 30 & 30 & 30 & 30 \\
\hline Total in minutes & 240 & 270 & 310 & 360 \\
\hline Total in hours & 4 & 4.50 & 5.17 & 6 \\
\hline
\end{tabular}

38. As stipulated in DO 31 , s. 2012, the time allotment for each subject is the minimum period for class interaction. The learning time can be extended to include off-school learning experiences at home or in the community for transfer of learning to real- life situations as provided for in the curriculum. Likewise, schools are encouraged to apportion time for arrival and assembly, library works, learning stations, reading and play exercises, lunch and recess, remediation and other related tasks.

39. Learning Stations provide time for Grades 1 to 3 students to investigate further any topic from any learning area with minimum supervision from the teacher. The stations may be for additional practice, enrichment, interest, or exploration.

40. Learners are provided hands-on activities on topics from the week's lessons, which may be accomplished individually, with a partner, or in a small group. The activities that learners may perform at the learning stations are explained by the teacher at the beginning of each week.

41. In addition to the activities shown in Table 1.3, Grades 1 to 3 classes should have one forty-minute $(40 \mathrm{~min}$.) session allotted per week for Homeroom.

42. Co-curricular activities, which are an extension of formal learning experiences, are provided to tap into and enrich the varied intelligences and skills of the learners. These come in the form of clubs, which are scheduled twice a month at 30 minutes per session. Various contests such as the National Schools Press Conference (NSPC) and the National Festival of Talents (NFOT) held annually by the DepEd also provide avenues to showcase the wide array of learners' aptitudes.

43. The medium of teaching and learning for this stage of the Basic Education Program observes a transition from the dominance of the mother tongue, which is used from Kindergarten until the $2^{\text {nd }}$ quarter of Grade 1 , to the accommodation of both Filipino and English, which are used in the $2^{\text {nd }}$ and $3^{\text {rd }}$ quarters of Grade 1 respectively until the end of the Program. 


\section{Assessment for Kindergarten to Grade 3 Learners}

44. The primary means of assessing Kindergarten learners is through observation throughout the different blocks of time. Assessment in Kindergarten is designed to help teachers understand learners' individual strengths and weaknesses, and enables teachers to design appropriate learning activities for them. Qualitative and non-numerical recording and grading systems are used to describe how Kindergarten learners are performing vis-à-vis the expected learning outcomes outlined in the Kindergarten Curriculum Guide.

45. Formative and summative classroom assessments are given from Grades 1 to 3 to improve student learning outcomes. DepEd Order 8, s. 2015 discusses formative and summative assessments done in the classroom. Formative assessment is an ongoing process of providing learners with immediate feedback on how well they are learning. The results of this type of assessment are documented but not included in computing learner's grades. Summative assessment, on the other hand, is used to measure whether learners have met the content and performance standards. The results of summative assessment are used as bases for computing learners' grades.

46. At the end of Grade 3, learners will be assessed through a national assessment to check if they are meeting key stage standards and evaluate the effectiveness of the Kindergarten to Grade 3 programs. Beginning School Year 20162017, DepEd shall conduct the Early Language, Literacy, and Numeracy Assessment (ELLNA) for Grade 3 learners. ELLNA, in a multiple-choice format, shall measure Grade 3 learners' language skills using learning area content and numeracy skills. Moreover, English, Filipino, and Mother Tongue shall be the languages of assessment for ELLNA. DepEd Order 55, s. 2016 discusses the details of the ELLNA.

\section{Key Stage 2: The Grades 4 to 6 Program}

47. Grades 4 to 6 provide opportunities for enhancement and application of learned literacy and numeracy competencies to varied content areas. What students have learned in Kindergarten to Grade 3, they should be able to apply in Grades 4 to 6 .

48. The objectives of Key Stage 2 are to provide learners avenues for:

a. Further enhancement of literacy and numeracy skills as preparation for the academic demands of high school;

b. Application of higher order thinking skills to be able to adjust, decide, and respond appropriately to varied situations; and

c. Further development of knowledge, skills, and attitudes to participate effectively in community- and nation-building activities.

49. From Grades 4 to 6 , the following are the required learning areasFilipino, English, Science, Mathematics, Araling Panlipunan, Edukasyong Pantahanan at Pangkabuhayan (EPP), Music, Art, Physical Education and Health (MAPEH), and Edukasyon sa Pagpapakatao (EsP). The table below provides a summary description of each learning area in Grades 4 to 6 : 
Table 1.4: Grades 4 to 6 Curriculum

\begin{tabular}{|c|c|c|c|}
\hline \multicolumn{4}{|c|}{ Grades 4 to 6 Curriculum } \\
\hline Grade Level & Grade 4 & Grade 5 & Grade 6 \\
\hline $\begin{array}{c}\text { Learning } \\
\text { Area }\end{array}$ & \multicolumn{3}{|c|}{ Description } \\
\hline Filipino & $\begin{array}{l}\text { The subject covers: } \\
\text { pagbasa, pagsulat, at } \\
\text { pakikipagtalastasan } \\
\text { nang wasto upang } \\
\text { maipahayag ang } \\
\text { kaalaman, ideya, at } \\
\text { damdaming angkop sa } \\
\text { kaniyang edad at sa } \\
\text { kulturang } \\
\text { kinabibilangan } \\
\text { nakikilahok at } \\
\text { pagpapaunlad } \\
\text { pamayanan. }\end{array}$ & $\begin{array}{l}\text { The subject covers: } \\
\text { pakikipagtalastasan, } \\
\text { mapanuring pag-iisip, } \\
\text { at pagpapahalaga sa } \\
\text { panitikan at kultura sa } \\
\text { pamamagitan ng iba't } \\
\text { ibang teksto/ } \\
\text { babasahing lokal at } \\
\text { pambansa. }\end{array}$ & $\begin{array}{l}\text { The subject covers: } \\
\text { pakikipagtalastasan, } \\
\text { mapanuring pag-iisip, } \\
\text { at pagpapahalaga sa } \\
\text { wika, panitikan, at } \\
\text { kultura upang } \\
\text { makaambag sa pag- } \\
\text { unlad ng bansa. }\end{array}$ \\
\hline English & $\begin{array}{l}\text { The subject covers: } \\
\text { various text types and } \\
\text { expression of ideas } \\
\text { accurately in both oral } \\
\text { and written forms, use } \\
\text { of the language to meet } \\
\text { everyday needs, and } \\
\text { independent reading to } \\
\text { extract relevant } \\
\text { information from } \\
\text { various text types. }\end{array}$ & $\begin{array}{l}\text { The subject covers: } \\
\text { different text types, } \\
\text { logical expression of } \\
\text { ideas in oral and } \\
\text { written forms, and } \\
\text { reading to meet various } \\
\text { needs. }\end{array}$ & $\begin{array}{l}\text { The subject covers: } \\
\text { communication of } \\
\text { feelings and ideas } \\
\text { orally and in writing } \\
\text { with a high level of } \\
\text { proficiency, and } \\
\text { various text types } \\
\text { and materials to } \\
\text { serve learning needs } \\
\text { in meeting a wide } \\
\text { range of life's } \\
\text { purposes. }\end{array}$ \\
\hline Science & $\begin{array}{l}\text { The subject covers: } \\
\text { changes in some } \\
\text { observable properties of } \\
\text { materials when mixed } \\
\text { with other materials or } \\
\text { when force is applied on } \\
\text { them; materials that do } \\
\text { not decay and the use of } \\
\text { this knowledge to help } \\
\text { minimize waste at } \\
\text { home, school, and in } \\
\text { the community; } \\
\text { functions of the } \\
\text { different internal parts } \\
\text { of the body in order to } \\
\text { practice ways to } \\
\text { maintain good health; } \\
\text { classification of plants }\end{array}$ & $\begin{array}{l}\text { The subject covers: } \\
\text { properties of materials } \\
\text { and changes in } \\
\text { properties due to } \\
\text { certain conditions; } \\
\text { healthful and hygienic } \\
\text { practices related to the } \\
\text { reproductive system } \\
\text { after describing } \\
\text { changes that } \\
\text { accompany puberty; } \\
\text { different modes of } \\
\text { reproduction among } \\
\text { plant and animal } \\
\text { groups and conduct an } \\
\text { investigation on } \\
\text { pollination; importance } \\
\text { of estuaries and }\end{array}$ & $\begin{array}{l}\text { The subject covers: } \\
\text { different separation } \\
\text { techniques; useful } \\
\text { mixtures such as } \\
\text { food, drinks and } \\
\text { herbal medicines; } \\
\text { how the different } \\
\text { organ systems of the } \\
\text { human body work } \\
\text { together; } \\
\text { classification } \\
\text { plants based on } \\
\text { reproductive } \\
\text { structures, } \\
\text { animals based on the } \\
\text { presence or lack of } \\
\text { backbone; } \\
\text { investigation on plant }\end{array}$ \\
\hline
\end{tabular}




\begin{tabular}{|c|c|c|c|}
\hline \multicolumn{4}{|c|}{ Grades 4 to 6 Curriculum } \\
\hline Grade Level & Grade 4 & Grade 5 & Grade 6 \\
\hline $\begin{array}{c}\text { Learning } \\
\text { Area }\end{array}$ & \multicolumn{3}{|c|}{ Description } \\
\hline & $\begin{array}{l}\text { and animals according } \\
\text { to where they live and } \\
\text { interactions among } \\
\text { living things and their } \\
\text { environment; traits of } \\
\text { animals and plants that } \\
\text { help them survive in the } \\
\text { environment; the effects } \\
\text { of push or pull on the } \\
\text { size, shape, and } \\
\text { movement of an object; } \\
\text { types of soil that is best } \\
\text { for certain plants; } \\
\text { importance of water in } \\
\text { daily activities; and } \\
\text { importance of the Sun } \\
\text { to life on Earth. }\end{array}$ & $\begin{array}{l}\text { intertidal zones and } \\
\text { their preservation; } \\
\text { movement of objects in } \\
\text { terms of distance and } \\
\text { time traveled; } \\
\text { materials and their } \\
\text { reactions to heat, light, } \\
\text { and sound; changes } \\
\text { that earth materials } \\
\text { undergo; emergency } \\
\text { plans with families in } \\
\text { preparation for } \\
\text { typhoons; patterns in } \\
\text { the natural events by } \\
\text { observing the } \\
\text { appearance of the } \\
\text { Moon. }\end{array}$ & $\begin{array}{l}\text { propagation; large } \\
\text { ecosystems such as } \\
\text { rainforests, coral } \\
\text { reefs, and mangrove } \\
\text { swamps; friction and } \\
\text { gravity; and heat, } \\
\text { light, sound, } \\
\text { electricity, and } \\
\text { motion as forms of } \\
\text { energy; earthquakes } \\
\text { and volcanic } \\
\text { eruptions and what } \\
\text { to do when they } \\
\text { occur; weather } \\
\text { patterns in the } \\
\text { course of a year; the } \\
\text { solar system, with } \\
\text { emphasis on the } \\
\text { motions of the Earth } \\
\text { as prerequisite to the } \\
\text { study of seasons in } \\
\text { another grade level. }\end{array}$ \\
\hline Math & $\begin{array}{l}\text { The subject covers: } \\
\text { understanding and } \\
\text { appreciation of key } \\
\text { concepts and skills } \\
\text { involving numbers and } \\
\text { number sense (whole } \\
\text { numbers up to } \\
\text { l00,000, multiplication } \\
\text { and division of whole } \\
\text { numbers, order of } \\
\text { operations, factors and } \\
\text { multiples, addition and } \\
\text { subtraction of fractions, } \\
\text { and basic concepts of } \\
\text { decimals including } \\
\text { money); geometry (lines, } \\
\text { angles, triangles, and } \\
\text { quadrilaterals); } \\
\text { patterns and algebra } \\
\text { (continuous and } \\
\text { repeating patterns and } \\
\text { number sentences); } \\
\text { measurement (time, }\end{array}$ & $\begin{array}{l}\text { The subject covers: } \\
\text { understanding and } \\
\text { appreciation of key } \\
\text { concepts and skills } \\
\text { involving numbers and } \\
\text { number sense (whole } \\
\text { numbers up to } \\
\text { 10,000,000, order of } \\
\text { operations, factors and } \\
\text { multiples, fractions } \\
\text { and decimals including } \\
\text { money, ratio and } \\
\text { proportion, percent); } \\
\text { geometry (polygons, } \\
\text { circles, solid figures); } \\
\text { patterns and algebra } \\
\text { (sequence and number } \\
\text { sentences); } \\
\text { measurement (time, } \\
\text { circumference, area, } \\
\text { volume, and } \\
\text { temperature); and } \\
\text { statistics and }\end{array}$ & $\begin{array}{l}\text { The subject covers: } \\
\text { understanding and } \\
\text { appreciation of key } \\
\text { concepts and skills } \\
\text { involving numbers } \\
\text { and number sense } \\
\text { (divisibility, order of } \\
\text { operations, fractions } \\
\text { and decimals } \\
\text { including money, } \\
\text { ratio and proportion, } \\
\text { percent, integers); } \\
\text { geometry (plane and } \\
\text { solid figures); } \\
\text { patterns and algebra } \\
\text { (sequence, } \\
\text { expression, and } \\
\text { equation); } \\
\text { measurement (rate, } \\
\text { speed, area, surface } \\
\text { area, volume, and } \\
\text { meter reading); and } \\
\text { statistics and }\end{array}$ \\
\hline
\end{tabular}




\begin{tabular}{|c|c|c|c|}
\hline \multicolumn{4}{|c|}{ Grades 4 to 6 Curriculum } \\
\hline Grade Level & Grade 4 & Grade 5 & Grade 6 \\
\hline $\begin{array}{c}\text { Learning } \\
\text { Area }\end{array}$ & \multicolumn{3}{|c|}{ Description } \\
\hline & $\begin{array}{l}\text { perimeter, area, and } \\
\text { volume); and statistics } \\
\text { and probability (tables, } \\
\text { bar graphs, and simple } \\
\text { experiments) as } \\
\text { applied-using } \\
\text { appropriate } \\
\text { technology-in critical } \\
\text { thinking, problem } \\
\text { solving, reasoning, } \\
\text { communicating, } \\
\text { making connections, } \\
\text { representations, and } \\
\text { decisions in real life. }\end{array}$ & $\begin{array}{l}\text { probability (tables, line } \\
\text { graphs and } \\
\text { experimental } \\
\text { probability) } \\
\text { applied-using } \\
\text { appropriate } \\
\text { technology-in critical } \\
\text { thinking, problem } \\
\text { solving, reasoning, } \\
\text { communicating, } \\
\text { making connections, } \\
\text { representations, and } \\
\text { decisions in real life. }\end{array}$ & $\begin{array}{l}\text { probability (tables, } \\
\text { pie graphs, and } \\
\text { experimental and } \\
\text { theoretical } \\
\text { probability) as } \\
\text { applied-using } \\
\text { appropriate } \\
\text { technology-in } \\
\text { critical thinking, } \\
\text { problem solving, } \\
\text { reasoning, } \\
\text { communicating, } \\
\text { making connections, } \\
\text { representations, and } \\
\text { decisions in real life. }\end{array}$ \\
\hline AP & $\begin{array}{l}\text { The subject covers: } \\
\text { pagka-Pilipino at ang } \\
\text { bansang Pilipinas na } \\
\text { may pagpapahalaga sa } \\
\text { pagkakaiba-iba ng mga } \\
\text { kulturang Pilipino batay } \\
\text { sa paggamit ng mga } \\
\text { kasanayan ray } \\
\text { heograpiya, pag-unawa } \\
\text { sa kultura at } \\
\text { kabuhayan, pakikilahok } \\
\text { sa pamamahala, at } \\
\text { pagpapahalaga sa mga } \\
\text { mithiin ng bansang } \\
\text { Pilipinas. }\end{array}$ & 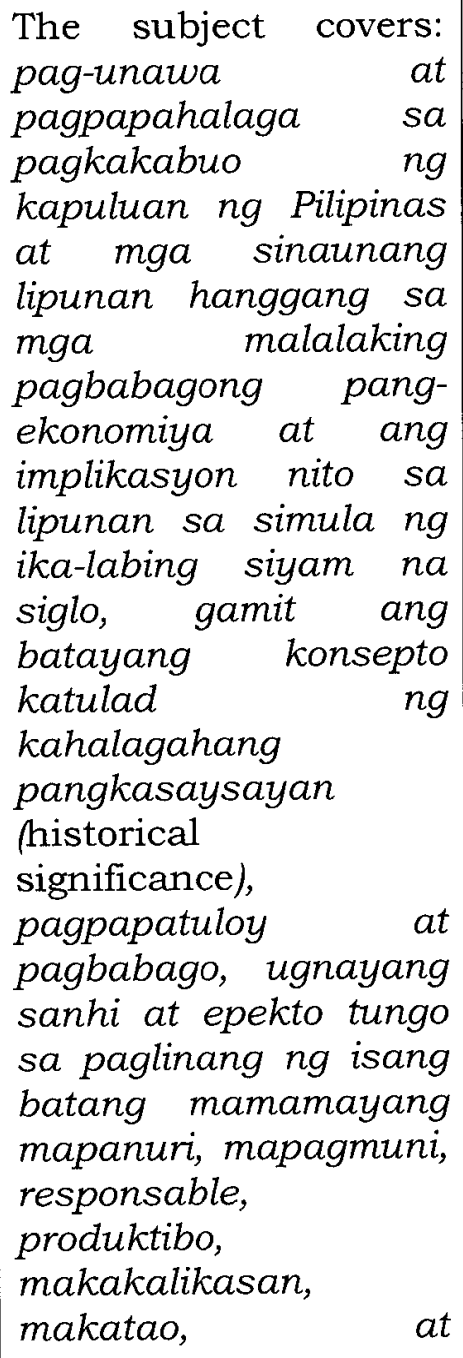 & 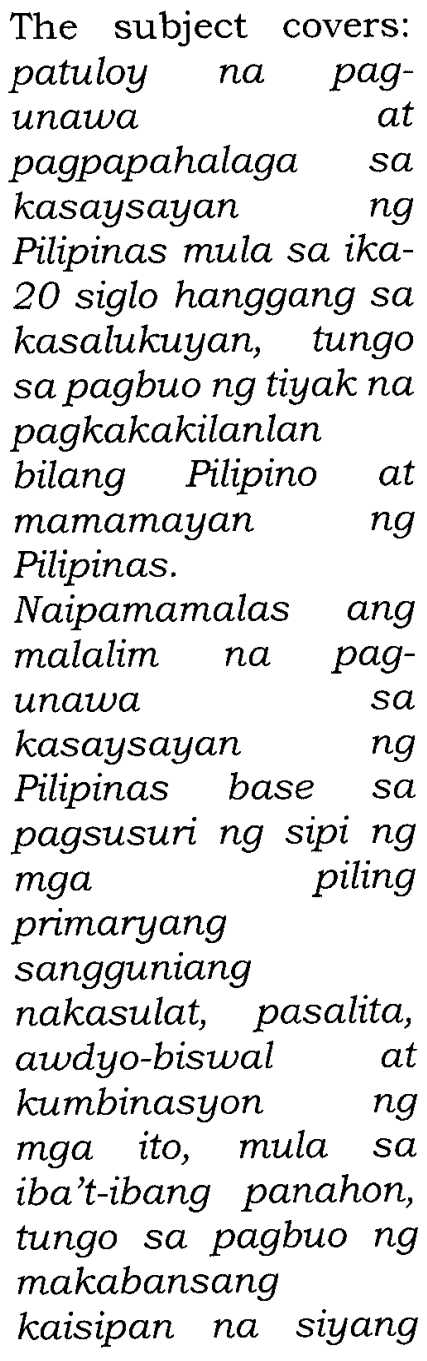 \\
\hline
\end{tabular}




\begin{tabular}{|c|c|c|c|}
\hline \multicolumn{4}{|c|}{ Grades 4 to 6 Curriculum } \\
\hline Grade Level & Grade 4 & Grade 5 & Grade 6 \\
\hline $\begin{array}{c}\text { Learning } \\
\text { Area }\end{array}$ & \multicolumn{3}{|c|}{ Description } \\
\hline & . & $\begin{array}{lr}\text { makabansa, at may } \\
\text { pagpapahalaga sa mga } \\
\text { usapin sa lipunan sa } \\
\text { nakaraan } & \text { at } \\
\text { kasalukuyan tungo sa } \\
\text { pagpanday } & \text { ng } \\
\text { maunlad } & \text { na } \\
\text { kinabukasan para } & \text { sa } \\
\text { bansa. } & \end{array}$ & $\begin{array}{l}\text { magsisilbing } \\
\text { basehan ng mas } \\
\text { malawak na } \\
\text { pananaw tungkol sa } \\
\text { mundo. }\end{array}$ \\
\hline $\begin{array}{l}\text { Edukasyong } \\
\text { Pantahanan } \\
\text { at } \\
\text { Pangkabuhay } \\
\text { an (EPP) }\end{array}$ & $\begin{array}{l}\text { The subject covers: } \\
\text { basic knowledge, skills, } \\
\text { and values in } \\
\text { agriculture, } \\
\text { entrepreneurship and } \\
\text { ICT, home economics, } \\
\text { and industrial arts that } \\
\text { can help improve self } \\
\text { and family life. }\end{array}$ & $\begin{array}{l}\text { The subject covers: } \\
\text { increased knowledge, } \\
\text { skills, and values in } \\
\text { entrepreneurship and } \\
\text { ICT, agriculture, home } \\
\text { economics, and } \\
\text { industrial arts toward } \\
\text { improving family life } \\
\text { and the community. }\end{array}$ & $\begin{array}{l}\text { The subject covers: } \\
\text { enhanced and } \\
\text { expanded knowledge } \\
\text { in entrepreneurship } \\
\& \text { ICT, agriculture, } \\
\text { home economics, and } \\
\text { industrial arts toward } \\
\text { the improvement of } \\
\text { the family's economic } \\
\text { life and the } \\
\text { community. }\end{array}$ \\
\hline Music & $\begin{array}{l}\text { The subject covers: } \\
\text { basic understanding of } \\
\text { the fundamental } \\
\text { processes in music and } \\
\text { art, through } \\
\text { performing, creating, } \\
\text { listening and observing, } \\
\text { and responding. }\end{array}$ & $\begin{array}{l}\text { The subject covers: } \\
\text { basic and fundamental } \\
\text { processes in music and } \\
\text { art, through } \\
\text { performing, creating, } \\
\text { listening } \\
\text { observing, } \\
\text { responding. }\end{array}$ & $\begin{array}{l}\text { The subject covers: } \\
\text { basic and } \\
\text { fundamental } \\
\text { processes through } \\
\text { performing, creating, } \\
\text { listening and } \\
\text { observing, and } \\
\text { responding, toward } \\
\text { the development of } \\
\text { appreciation of music } \\
\text { and art, and the } \\
\text { acquisition of basic } \\
\text { knowledge and skills. }\end{array}$ \\
\hline Arts & $\begin{array}{l}\text { The subject covers: } \\
\text { basic understanding of } \\
\text { the fundamental } \\
\text { processes in music and } \\
\text { art, through } \\
\text { performing, creating, } \\
\text { listening and observing, } \\
\text { and responding. }\end{array}$ & $\begin{array}{l}\text { The subject covers: } \\
\text { basic and fundamental } \\
\text { processes in music and } \\
\text { art, through } \\
\text { performing, creating, } \\
\text { listening } \\
\text { observing, and } \\
\text { responding. }\end{array}$ & $\begin{array}{l}\text { The subject covers: } \\
\text { basic and } \\
\text { fundamental } \\
\text { processes through } \\
\text { performing, creating, } \\
\text { listening and } \\
\text { observing, and } \\
\text { responding, towards } \\
\text { the development of } \\
\text { appreciation of music } \\
\text { and art, and the }\end{array}$ \\
\hline
\end{tabular}




\begin{tabular}{|c|c|c|c|}
\hline \multicolumn{4}{|c|}{ Grades 4 to 6 Curriculum } \\
\hline Grade Level & Grade 4 & Grade 5 & Grade 6 \\
\hline $\begin{array}{c}\text { Learning } \\
\text { Area }\end{array}$ & \multicolumn{3}{|c|}{ Description } \\
\hline & & & $\begin{array}{l}\text { acquisition of basic } \\
\text { knowledge and skills. }\end{array}$ \\
\hline $\begin{array}{l}\text { Physical } \\
\text { Education }\end{array}$ & $\begin{array}{l}\text { The subject covers: } \\
\text { target games, } \\
\text { striking/fielding games, } \\
\text { invasion games; and } \\
\text { folk, indigenous, ethnic, } \\
\text { traditional, and creative } \\
\text { dances }\end{array}$ & $\begin{array}{l}\text { The subject covers: } \\
\text { target games, } \\
\text { striking/fielding } \\
\text { games, invasion } \\
\text { games; and indigenous, } \\
\text { folk, elk, inditional, and } \\
\text { ethnic, tradition } \\
\text { creative dances }\end{array}$ & $\begin{array}{l}\text { The subject covers: } \\
\text { target games, } \\
\text { striking/fielding } \\
\text { games, invasion } \\
\text { games; and folk, } \\
\text { indigenous, ethnic, } \\
\text { traditional, and } \\
\text { creative dances }\end{array}$ \\
\hline Health & $\begin{array}{l}\text { The subject covers: } \\
\text { nutrition; prevention } \\
\text { and control of diseases } \\
\text { and disorders; } \\
\text { substance use and } \\
\text { abuse; and injury } \\
\text { prevention, safety, and } \\
\text { first aid, leading to the } \\
\text { achievement } \\
\text { optimum health and } \\
\text { well-being. }\end{array}$ & $\begin{array}{l}\text { The subject covers: } \\
\text { nature of personal } \\
\text { health; growth and } \\
\text { development; } \\
\text { substance use and } \\
\text { abuse; and community } \\
\text { and environmental } \\
\text { health, which helps to } \\
\text { achieve optimum } \\
\text { health and well-being. }\end{array}$ & $\begin{array}{l}\text { The subject covers: } \\
\text { personal health, } \\
\text { prevention and } \\
\text { control of diseases } \\
\text { and } \\
\text { consumer health; } \\
\text { and injury } \\
\text { prevention, safety, } \\
\text { and first aid to } \\
\text { achieve optimum } \\
\text { health and well- } \\
\text { being. }\end{array}$ \\
\hline $\begin{array}{l}\text { Edukasyon sa } \\
\text { Pagpapakatao }\end{array}$ & $\begin{array}{l}\text { The subject covers: } \\
\text { pag-unawa sa mga } \\
\text { makabuluhang gawain } \\
\text { na may kaakibat na } \\
\text { pagpapahalaga tungo } \\
\text { sa wasto, maayos, } \\
\text { masaya, rapang } \\
\text { mapayapang } \\
\text { pamumuhay para sa } \\
\text { sarili, kapwa, bansa, at } \\
\text { Diyos. }\end{array}$ & $\begin{array}{lr}\text { The subject covers: } \\
\text { pag-unawa sa } \\
\text { masusing pagsusuri sa } \\
\text { pagpapahayag, } \\
\text { pagganap ng tungkulin } \\
\text { na may pananagutan } \\
\text { at pagsasabuhay ng } \\
\text { mga ito tungo sa } \\
\text { masaya, mapayapa, at } \\
\text { maunlad na } \\
\text { pamumuhay para sa } \\
\text { sarili/ mag-anak, } \\
\text { kapwa/ pamayanan, } \\
\text { bansal daigdig, at } \\
\text { Diyos. }\end{array}$ & 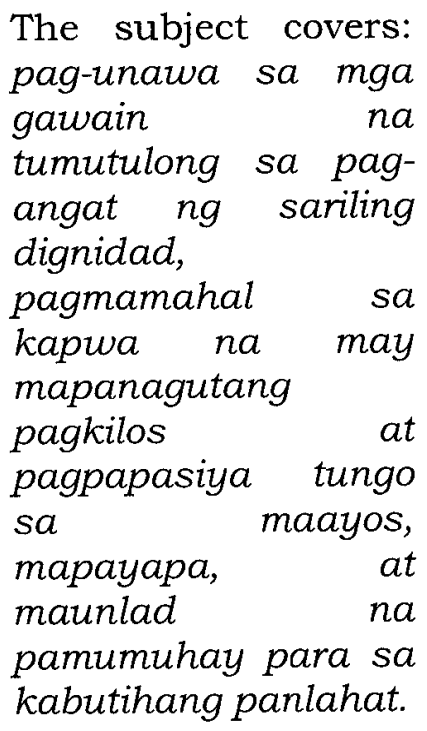 \\
\hline
\end{tabular}

50. Table 1.5 shows the time allotment for learning areas in Grades 4 to 6 . 
Table 1.5: Time Allotment for Grades 4 to 6

\begin{tabular}{|l|l|}
\multicolumn{1}{c|}{ LEARNING AREA } & \multicolumn{1}{c|}{ TIME ALLOTMENT } \\
\cline { 2 - 2 } Filipino & Number of Minutes Daily \\
\hline English & 50 \\
\hline Science & 50 \\
Mathematics & 50 \\
Araling Panlipunan & 50 \\
\hline EPP/TLE & 40 \\
MAPEH & 50 \\
EsP & 40 \\
\hline Total (in minutes) & 30 \\
\hline Total (in hours) & $\mathbf{3 6 0}$ \\
\hline
\end{tabular}

51. In addition to the activities shown in Table 1.5, Grades 4 to 6 classes should have one forty-minute $(40 \mathrm{~min}$.) session allotted for the Homeroom Guidance Program per week. Special Curricular Programs shall also be offered twice a week at forty minutes per session. See the Homeroom Guidance Program policy and the Special Curricular Programs policy (both to be issued) for details. Clubs should meet for 40 minutes twice a month as well. Details on clubs will be released in a separate issuance.

52. Likewise, schools are encouraged to apportion time for arrival and assembly, library work, lunch and recess, remediation and other related tasks.

53. To foster love for reading and encourage learners to do their projects collaboratively, 40 minutes once a week to be scheduled at the end of the school day will be reserved for reading and group work. Moreover, additional minutes may be utilized during weeks when there is no scheduled club activity for group projects or individual study time/library time.

54. The medium of teaching and learning used in Grades 4 to 6 are Filipino and English. The learning areas taught in these languages are shown in Table 1.6.

Table 1.6: Medium of Teaching and Learning in Grades 4 to 6

\begin{tabular}{|l|l|l|l|}
\hline $\begin{array}{c}\text { Medium of } \\
\text { Teaching and } \\
\text { Learning }\end{array}$ & \multicolumn{1}{|c|}{ Grade 4 } & Grade 5 & \multicolumn{1}{c|}{ Grade 6 } \\
& & $\begin{array}{l}\text { English } \\
\text { Science } \\
\text { Math } \\
\text { English }\end{array}$ & $\begin{array}{l}\text { Music } \\
\text { English }\end{array}$ \\
& $\begin{array}{l}\text { Science } \\
\text { Math }\end{array}$ & PE \\
& & EPP \\
\hline & Filipino & Filipino \\
& Araling Panlipunan & Araling Panlipunan \\
& Edukasyon sa Pagpapakatao & Pagpapakatao \\
Filipino & Music & \\
& Arts & \\
& PE & \\
\hline
\end{tabular}




\begin{tabular}{|c|l|l|l|}
\hline $\begin{array}{c}\text { Medium of } \\
\text { Teaching and } \\
\text { Learning }\end{array}$ & Grade 4 & Grade 5 & Grade 6 \\
\hline & EPP & \\
\hline
\end{tabular}

\section{Assessment for Grades 4 to 6}

55. Formative and summative classroom assessments are also done from Grade 4 to Grade 6 to improve student learning outcomes.

56. At the end of Grade 6 , learners will be assessed through national and international assessments to check if they are meeting key stage standards and evaluate the effectiveness of the Grades 4 to 6 programs. DepEd Order 8, s. 2015 and Deped Order 55, s. 2016 talk about the assessments conducted in the classroom and at the national level.

\section{Features of Elementary Education}

\section{A. The Multigrade Program}

57. The Multigrade Program was formally introduced to public schools to ensure continuous provision of quality education services in far-flung, isolated, and underserved communities in the archipelago. Public elementary schools were encouraged to provide complete grade levels or to organize combination and multigrade classes in schools with low enrollment.

58. The Multigrade Program supports the strategic direction of DepEd to expand access to and improve the quality of basic education. The program aims to:

a. Improve access to basic education in disadvantaged and less accessible communities with low enrollment;

b. Organize multigrade classes in public and private schools to allow the use of flexible curricula for pedagogical and philosophical considerations;

c. Improve instruction in multigrade classrooms by providing appropriate teaching and learning materials and resources, technical assistance for teachers and school administrators, and conducting continuous monitoring and evaluation of classes; and

d. Encourage stakeholders' partnership building and linkages toward improving multigrade schools and students' participation and learning performance.

59. Details on program standards, variations, implementation, and evaluation will be described in a separate issuance.

\section{B. Homeroom Guidance Program for Elementary Pupils}

60. The Homeroom Guidance Program (HGP) seeks to develop the personality of learners through an understanding of the self and the environment, and prepare them for their roles in the family, work, higher education, and the community. The HGP was designed as a way to strengthen the functions of school guidance. As such, HGP gives importance to individual learners. The HGP activities 
aim to develop each learner's personality and enhance the students' social relationships with teachers and other classmates.

\section{Program for the Gifted}

61. The Program for the Gifted is a concrete expression of the country's unwavering commitment and dedication to transform and empower every Filipino gifted learner to develop their full potential and become invaluable assets of the nation. The program aims to provide opportunities, encouragement and support in the development of their gifts or talents. These learners are observed to have exceptional abilities beyond their age. Programs may include acceleration, enrichment of the curriculum, training, mentoring and coaching. These programs are supported by proper assessments, developmentally appropriate interventions, and encouraging learning environments. Policies for these programs will be developed in separate issuances.

\section{Special Curricular Programs}

62. Special Curricular Programs (SCPs) are designed to provide learners multiple and varied experiences in elementary and secondary education that allow them to explore their potentials and interests. These special programs will cater to the needs and interests of $21^{\text {st }}$ century learners with the view of preparing them for the different curricular options offered by the K to 12 Secondary Education Program.

a. Special Science Elementary School (SSES) is a nationwide program that aims to provide a learning environment to the gifted and talented students through special Mathematics and Science curricula geared toward the development of God-loving, globally competitive, nationalistic, creative, ecologically aware, scientifically and technologically oriented and skilled individuals who are empowered through lifelong learning skills.

b. Special Program in the Arts (SPA) for Grades 4 to 6 is a nationwide program for students with potentials in the Arts, namely, Music, Visual Arts, Drama, Media Arts, Creative Writing and Dance. In localities with living cultural traditions, an Elementary School may offer traditional Arts as a specialization.

It is envisioned to produce holistically developed young and excellent artists and to preserve the Filipino cultural heritage through a learnercentered curriculum. It aims to provide avenues for students with potentials in any field of the Arts to progressively enhance their skills.

Art education is an integral component of a balanced educational program. The SPA schools shall offer a comprehensive Arts Program covering a range of art forms and disciplines, which will lay down the foundation for learners to pursue the SPA in Junior High School.

c. Special Program in Sports (SPS) for Grades 4 to 6 students was conceived to address the needs of talented students in different sports disciplines and to identify and create a pool of athletes who will be trained to compete in national and international sports competitions. It aims to enhance athletic potentials, achieve school-sport balance, and prepare learners for work or higher learning. 
d. Special Program in Journalism. The Campus Journalism Act (Republic Act No. 7079), promulgated in 1991, provides for the promotion and development of Campus Journalism as a means of (1) strengthening ethical values, (2) encouraging critical and creative thinking, and (3) developing moral character and personal discipline among the Filipino youth.

DepEd, through the Bureau of Learning Delivery (BLD) and the Bureau of Curriculum Development (BCD), is mandated to undertake various programs and projects aimed at promoting journalism in the public and private schools in the Philippines. Through the National Schools Press Conference, campus journalists shall:

i. Demonstrate understanding of the importance of journalism by expressing it through different journalistic endeavors and approaches;

ii. Sustain advocacy on social consciousness and uphold the interest of the students to pursue careers/studies in journalism;

iii. Promote responsible journalism and fair and ethical use of all forms of media; and

iv. Enhance journalistic competence through healthy and friendly competitions.

63. A separate policy will be issued with details on the Special Curricular Programs.

\section{E. Co-curricular Activities}

64. Supreme Student Government (SSG) is the foremost co-curricular student organization authorized to operate and implement pertinent programs, projects, and activities in school nationwide. It lays the groundwork for good governance, volunteerism, unity, and cooperation by providing the students various venues where they can improve their leadership knowledge, skills, and attitudes. It trains students to become better members of society in accordance with the ideals and principles of participatory democracy and good citizenship.

65. For the Elementary grades, the time allotment for each subject is the minimum period for class interaction. The learning time can be extended to include off-school learning experiences at home or in the community. These will help children connect their real-life experiences with concepts and topics they learn in school.

\section{F. Special Education Program}

66. In the Elementary level, appropriate Special Education (SpEd) programs and services are provided for learners with disabilities. These programs and services refer to early intervention programs, curriculum adaptations, learning resource support, guidance programs, and transition program. To address the learners' health and medical needs, the schools' referral system to medical and allied medical-service providers is an essential part of services for learners with disabilities. This will only be possible through strong school-community collaboration and 
partnerships with parents and families, local government units, nongovernment agencies and civic organizations.

67. Classroom-based screening assessments will be conducted as appropriate. The data will be triangulated with interviews with parents/guardians about the learners in the home environment as well as with the school grades/class performance. Should there be a need to administer or use other tools to further probe into the learner's cognitive, social, physical, perceptual and motor abilities, appropriate screening tools may be used. Results of such assessments must be discussed with the School Head and if possible, the division focal persons for guidance and special education so that the intervention plan for the learner can be prepared and implemented in collaboration with the learner's family.

68. Appropriate and sufficient learning support must be provided to ensure that learners with disabilities will be helped to learn in the ways they learn best. To ensure that learners with disabilities have access to the $K$ to 12 curriculum, curriculum contextualization, adaptations, and modifications are made depending on the learner's abilities, needs and learning goals. Examples of these are time allotment modifications, adapted Physical Education, assistive devices and modified learning resources.

69. Learners with disabilities who are in the transition program are prepared to successfully move forward into more inclusive and integrated learning provisions. Included in these transition programs are interventions that enable learners to move from home to school, class to class, and/or from school to another school. A policy for learners with disabilities will be issued separately.

\section{v. Flexible Learning Options}

70. Flexible Learning Options (FLOs) for both Elementary and Secondary education are discussed in Annex 3. 


\section{References:}

Batas Pambansa Blg. 232: An Act Providing for the Establishment and Maintenance of an Integrated System of Education Act of 1982.

Cochrane, A., Longworth, A. and Craig, C. (2007). Watching your child grow: Developmental milestones for children aged 0-12 \& other information for families. 3rd ed. [PDF file]. Available from: http://www.nchn.org.au/ acfhresources/docs/WatchingYourChildGrow.pdf [Accessed 29 July 2014].

Dekker, Diane. "Key Components of a MTBMLE Program." Paper presented at the first Philippine MLE Conference, Cagayan de Oro, 18-20 February 2001.

DepEd Memorandum No. 1, s. 2016: Administration of the Language Assessment for Primary Grades (LAPG) and the National Achievement Test for Grade Six (NAT G6) for School Year (SY) 2015-2016. 6 January 2016.

DepEd Order No. 16, s. 2012: Guidelines on the Implementation of the Mother Tongue-Based Multilingual Education (MTB-MLE). 17 February 2012.

DepEd Order No. 32, s. 2012: Implementing Rules and Regulations of Republic Act (RA) No. 10157 otherwise known as the "Kindergarten Education Act".

DepEd Order No. 37, s. 2011: Policies and Guidelines on the Implementation of the Universal Kindergarten Education for SY 2011-2012. 4 May 2011.

DepEd Order No. 107, s. 189: Standards for the Organization and Operation of Preschools (Kindergarten Level). 10 November 1989.

Malone, Susan. 2013. Essential Components of Strong and Sustained MTBMLE Programs. http://www.sil.org/sites/default/files/files/essential_components _of_mtb_mle_programs.pdf

Mercado, Ricci. "The Individualized Educational Plan: Guidelines and Principles." Individualization of Educational Content and Strategies: Trends and Application in Varied Programs for Children with Special Needs (First Edition 2002).

Papalia, D., \& Olds, S. (1995). Human Development (6th ed. ed.). New York: McGraw-Hill, Inc.

Republic Act No. 10533: Enhanced Basic Education Act of 2013.

The Growing Child: School-Age (6 to 12 Years). (n.d.). The Growing Child: SchoolAge (6 to 12 Years). Retrieved July 29, 2014, from http:/ / www.stanfordchildrens. $\mathrm{org} / \mathrm{en} /$ topic/default?id=the-growing-child-school-age-6-to-12-years-90-P02278

The National Early Learning Framework of the Philippines. (2010): ECCD Council.

World Bank, 2016. http://www sreb.org/general-information/who-adult-learner 


\section{ANNEX 2: SECONDARY EDUCATION}

\section{Introduction}

1. Secondary Education is composed of two key stages of the $\mathrm{K}$ to 12 Basic Education Program, namely, Junior High School comprising Grades 7 to 10, and Senior High School covering Grades 11 to 12. Learners in Secondary Education are generally from 12 to 17 years old. They may also be adults, beyond 18 years old, who were not able to participate and complete basic education.

2. The Implementing Rules and Regulations of Republic Act No. 10533, the Enhanced Basic Education Act of 2013, describes Secondary Education as "the third stage of compulsory basic education. It consists of four (4) years of junior high school education and two (2) years of senior high school education. The entrant age to the junior and senior high school levels are typically twelve (12) and sixteen (16) years old, respectively." Additionally, Secondary Education includes co-curricular activities.

3. According to DepEd Order No. 31, s. 2012 entitled Policy Guidelines on the Implementation of Grades 1 to 10 of the $K$ to 12 Basic Education Curriculum (BEC) Effective School Year 2012-2013, at the end of Junior High School, learners are expected to "demonstrate communicative competence; think intelligently, critically, and creatively in life situations; make informed and values-based decisions; perform their civic duties; use resources sustainably; and participate actively in artistic and cultural activities and in the promotion of wellness and lifelong fitness." On the other hand, Senior High School is expected to prepare and equip graduates for Tertiary Education, middle-level skills development, employment, and entrepreneurship.

\section{Characteristics of Learners in Secondary Education}

4. Learners in Secondary Education are adolescents. Adolescents are between 10 and 19 years old. They have specific health and developmental needs and rights (World Health Organization, 2014). Adolescence is considered as a transitional period from childhood to adulthood (Psychology Today, n.d.).

\section{A. Early Adolescence}

5. Early adolescence covers the ages between 12 to 15 years old. This is a critical phase because during this time, young teens experience accelerated growth and development. According to UNICEF (2011): "It is at this stage that physical changes generally commence, usually beginning with a growth spurt and soon followed by the development of the sex organs and secondary sexual characteristics. These external changes are often very obvious and can be a source of anxiety as well as excitement or pride for the individual whose body is undergoing the transformation."

6. Early adolescence is a time of physical, socio-emotional, and intellectual development. During early adolescence, the onset of puberty happens when young teens undergo physiological changes triggered by the release of hormones. As such, young teens experience rapid increases in height, weight, and growth of their internal organs, as well as their skeletal and muscular systems. Puberty leads to growth not only in primary sex characteristics but also in secondary sex characteristics. In girls, these changes include the growth of breasts, pubic and 
underarm hair, increased width and depth of pelvis, and changes in voice and skin. In boys, these include the growth of facial, underarm, and pubic hair, changes in voice and skin, and broadening of shoulders (Papalia \& Olds, 1995). Schools must ensure that young teens are exposed to a positive environment that helps them adjust to their physiological transformations.

7. Simultaneously, young adolescents begin exhibiting greater independence and start developing their personalities and interests. At this time, they make decisions about friends, studies, and sports or hobbies. Many of them show a strong need to belong to a group. They also begin to experience feelings of attraction, which occur as they encounter gender identity or gender expression issues.

8. It is at this stage that young teens also develop abstract and independent thinking. They display a curiosity for topics that resonate with them, and for those that they find both useful and interesting. Young adolescents at this time also "acquire the ability to develop and test hypotheses, analyze and synthesize data, grapple with complex concepts, and think reflectively" (Association for Middle Level Education, 2016). They are also able to think about their thinking (metacognition).

9. Schools must ensure that teachers of young teens recognize and address the wide-ranging diversity of cognitive abilities inside their classrooms. To do this, teachers can employ a variety of teaching methods and strategies. Teachers may differentiate instruction while also connecting lessons to real-life experiences. At this stage, teachers may provide opportunities to young adolescent learners for active learning, exploration, and collaboration with peers and adults. Young teens will benefit from school programs that promote independence and freedom. At this time, access to activities in which young teens can dialogue and work with peers is important such as clubs, student government, and groups in which they can take leadership roles. Schools should also provide developmentally appropriate reproductive health education programs, and mental and psychosocial support services to young adolescents.

\section{B. Middle to Late Adolescence}

10. This period covers the ages between 15 and 19 years old. Teenagers at this stage will most likely be over the dramatic changes brought about by puberty. Their physiological development will be almost complete. During this stage, teenagers will be close to their adult height and weight.

11. Most teenagers will continue adjusting to their changing bodies and will be more concerned about their physical appearance. Because of this, they will spend more time grooming themselves, exercising, and changing their looks. This is healthy for as long as they are of the expected body weight. According to UNICEF (2011), "Girls in late adolescence tend to be at greater risk than boys of negative health outcomes, including depression, and these risks are often magnified by gender-based discrimination and abuse. Girls are particularly prone to eating disorders such as anorexia and bulimia; this vulnerability derives in part from profound anxieties over body image that are fueled by cultural and media stereotypes of feminine beauty."

12. At this stage, most teenagers' sense of identity, including their sexual orientation and gender identity or gender expression (SOGIE), is firmer and clearer. They will relate more with their peers and seek greater emotional independence from 
their parents. They also show greater interest in romantic relationships. With guidance, teenagers will be able to balance the influence of their families with that of their friends.

13. Learners during this time experiment with adult roles. They also exhibit "risk-taking" behavior that declines in late adolescence (UNICEF, 2011). With proper supervision and open discussions about confusing situations they encounter, learners at this stage may be helped to avoid experimentation with dangerous substances as well as irresponsible sexual behavior. Teenagers with good role models show greater emotional stability and concern for others. With exposure, they develop good work habits, showing concern and interest in their future (Centers for Disease Control and Prevention, 2016).

14. Cognitively, learners at this stage will be capable of more abstract thinking and organizing abstract thought. They can think hypothetically and understand underlying principles that they can apply in new situations. They have the ability to consider multiple viewpoints or diverse perspectives. They will also show philosophical and idealistic thinking (State Adolescent Health Resource Center, n.d.).

15. UNICEF in its 2011 report, "State of the World's Children" (SOWC), underscored the need to invest in adolescents, describing adolescence as both a time of vulnerability and opportunity. The report recommends providing adolescents education that will empower them to face the economic crisis, political instability, rapid urban growth, natural disasters, and other pressing global challenges. According to the report, "Rich and poor alike, adolescents will have to deal with the intergenerational implications of the current economic turmoil, including the structural unemployment that may persist in its wake. They will have to contend with climate change and environmental degradation, explosive urbanization and migration, ageing societies and the rising cost of health care, the HIV and AIDS pandemic, and humanitarian crises of increasing number, frequency and severity" (p. 4). Additionally, the Convention on the Rights of the Child (CRC) recommends for governments to develop "different forms of Secondary Education, including general and vocational education" (1995), and make it accessible to every child.

16. In its 2016 SOWC report, UNICEF turns to the issue of equity and calls on governments of the world to ensure equity as the central goal for access and learning (UNICEF, 2016). It says that investing in quality education for all, especially disadvantaged children and adolescents helps them break the intergenerational cycle of poverty that they experience.

\section{Key Stage 3: Junior High School}

17. The goals of the JHS Curriculum are 1) to provide learners with opportunities to learn fundamental concepts at a higher degree of complexity; and 2) to help learners develop an increasing degree of independence in applying knowledge, skills, and values learned.

\section{A. The JHS Learning Areas}

18. The Junior High School Curriculum has eight (8) learning areas namely, (1) English, (2) Filipino, (3) Mathematics, (4) Science, (5) Araling Panlipunan (AP), (6) Edukasyon sa Pagpapakatao (EsP), (7) Music, Arts, Physical Education and Health (MAPEH), and (8) Technology and Livelihood Education (TLE). Each learning area is studied in four quarters within one academic year. All learning areas in Junior 
High School and Senior High School have a Curriculum Guide (CG) with program standards, learning area standards, course description, and key stage standards. Additionally, the CGs also articulate grade level standards, content standards and performance standards for each quarter. For example, for the first quarter (Q1) of Grade 10 English, the following are the program standards, content standards, and performance standards as provided in Table 2.1 .

Table 2.1: Grade 10 English Standards

\begin{tabular}{|l|l|}
\hline Program Standard & $\begin{array}{l}\text { The learner demonstrates communicative competence } \\
\text { through his/her understanding of literature and other text } \\
\text { types for a deeper appreciation of Philippine culture and } \\
\text { those of other countries. }\end{array}$ \\
\hline Grade Level Standard & $\begin{array}{l}\text { The learner demonstrates communicative competence } \\
\text { through his/her understanding of literature and other text } \\
\text { types for a deeper appreciation of World Literature, } \\
\text { including Philippine Literature. }\end{array}$ \\
\hline Content Standard & $\begin{array}{l}\text { The learner demonstrates an understanding of how World } \\
\text { Literature and other text types serve as ways of expressing } \\
\text { and resolving personal conflicts, as well as how to use } \\
\text { strategies in linking textual information; repairing, } \\
\text { enhancing communication, public speaking, emphasis } \\
\text { markers in persuasive texts, different forms of modals, and } \\
\text { reflexive and intensive pronouns. }\end{array}$ \\
\hline Performance Standard & $\begin{array}{l}\text { The learner composes a short but powerful persuasive text } \\
\text { using a variety of persuasive techniques and devices. }\end{array}$ \\
\hline
\end{tabular}

19. The curriculum guide for the learning areas is anchored on a conceptual framework for the teaching of the subject in the curriculum guides. Each conceptual framework contains the goals of teaching the subject, and the teaching methods and approaches. This is presented with a schematic diagram and an accompanying write-up in the curriculum guides for each learning area. Table 2.2 provides a summary description of each learning area in Junior High School:

Table 2.2. The Junior High School (JHS) Core Curriculum

\begin{tabular}{|c|c|c|c|c|}
\hline \multicolumn{5}{|c|}{ The Junior High School (JHS) Core Curriculum } \\
\hline Grade Level & Grade 7 & Grade 8 & Grade 9 & Grade 10 \\
\hline $\begin{array}{c}\text { Learning } \\
\text { Area }\end{array}$ & \multicolumn{4}{|c|}{ Description } \\
\hline English & $\begin{array}{lr}\text { This } & \text { subject } \\
\text { focuses } & \text { on } \\
\text { Philippine } & \\
\text { Literature } & \text { in } \\
\text { English. } & \\
\end{array}$ & $\begin{array}{l}\text { This subject } \\
\text { covers the study } \\
\text { of Afro-Asian } \\
\text { literature. }\end{array}$ & $\begin{array}{l}\text { This subject } \\
\text { focuses on } \\
\text { Anglo- } \\
\text { American } \\
\text { Literature. }\end{array}$ & $\begin{array}{l}\text { This subject } \\
\text { introduces } \\
\text { students } \\
\text { World } \\
\text { Literature. } \\
\end{array}$ \\
\hline Filipino & $\begin{array}{l}\text { This subject } \\
\text { covers grammar in } \\
\text { Filipino and } \\
\text { literature from } \\
\text { Luzon, Visayas, } \\
\text { and Mindanao. It } \\
\text { introduces }\end{array}$ & $\begin{array}{l}\text { This subject } \\
\text { covers grammar } \\
\text { in Filipino and } \\
\text { literature from } \\
\text { different periods } \\
\text { including } \\
\text { ancient time, }\end{array}$ & $\begin{array}{l}\text { This subject } \\
\text { covers } \\
\text { grammar in } \\
\text { Filipino and } \\
\text { literature from } \\
\text { Southeast } \\
\text { Asia, East }\end{array}$ & $\begin{array}{l}\text { This subject } \\
\text { covers grammar } \\
\text { in Filipino and } \\
\text { literature from } \\
\text { the } \\
\text { Mediterranean, } \\
\text { the West, and }\end{array}$ \\
\hline
\end{tabular}




\begin{tabular}{|c|c|c|c|c|}
\hline \multicolumn{5}{|c|}{ The Junior High School (JHS) Core Curriculum } \\
\hline Grade Leve1 & Grade 7 & Grade 8 & Grade 9 & Grade 10 \\
\hline Learning & \multicolumn{4}{|c|}{ Description } \\
\hline & $\begin{array}{l}\text { students to } \\
\text { different literary } \\
\text { forms in Filipino, } \\
\text { including } \\
\text { kuwentong bayan, } \\
\text { pabula, epiko, } \\
\text { maikling kuwento, } \\
\text { dula, alamat, } \\
\text { bulong at awiting } \\
\text { bayan, tulang } \\
\text { panudyo, tugmang } \\
\text { de gulong, } \\
\text { palaisipan/ } \\
\text { bugtong, mito, } \\
\text { sanaysay. } \\
\text { Learners at this } \\
\text { level study the } \\
\text { korido, Ibong } \\
\text { Adarna. }\end{array}$ & $\begin{array}{l}\text { Spanish period, } \\
\text { Japanese } \\
\text { occupation, } \\
\text { American } \\
\text { occupation, the } \\
\text { Commonwealth, } \\
\text { up to the } \\
\text { present. It } \\
\text { introduces } \\
\text { students to } \\
\text { different literary } \\
\text { forms in Filipino, } \\
\text { including } \\
\text { karunungang } \\
\text { bayan } \\
\text { (salawikain, } \\
\text { sawikain, } \\
\text { kasabihan), } \\
\text { alamat/ } \\
\text { maikling } \\
\text { kuwento, epiko, } \\
\text { tula, balagtasan, } \\
\text { sarswela, } \\
\text { sanaysay, } \\
\text { popular } \\
\text { babasahin na } \\
\text { (pahayagan, } \\
\text { komiks, magasin, } \\
\text { kontemporaryong } \\
\text { dagli), } \\
\text { komentaryong } \\
\text { programang } \\
\text { panradyo, } \\
\text { komentaryong } \\
\text { programang } \\
\text { pantelebisyon, } \\
\text { and pelikula. } \\
\text { Students at this } \\
\text { level study } \\
\text { Florante } \\
\text { Laura. }\end{array}$ & $\begin{array}{l}\text { Asia, and West } \\
\text { Asia. It } \\
\text { introduces } \\
\text { students to } \\
\text { literary forms } \\
\text { that include } \\
\text { maikling } \\
\text { kuwento, } \\
\text { nobela, tula, } \\
\text { sanaysay, } \\
\text { dula, tanka at } \\
\text { haiku, pabula, } \\
\text { parabula, } \\
\text { elehiya/awit, } \\
\text { alamat, and } \\
\text { epiko. } \\
\text { Students at } \\
\text { this level } \\
\text { study the } \\
\text { novel Noli Me } \\
\text { Tangere. }\end{array}$ & $\begin{array}{l}\text { Africa and } \\
\text { Persia. It } \\
\text { introduces } \\
\text { students to } \\
\text { literary forms } \\
\text { that include } \\
\text { mitolohiya, } \\
\text { parabula, } \\
\text { sanaysay, } \\
\text { epiko/tula, } \\
\text { maikling } \\
\text { kuwento, nobela } \\
\text { (isang } \\
\text { kabanata), } \\
\text { dula, tula, } \\
\text { anekdota and } \\
\text { epiko/maikling } \\
\text { kuwento. } \\
\text { Students at this } \\
\text { level study } \\
\text { the novel El } \\
\text { Filibusterismo. }\end{array}$ \\
\hline Mathematics & $\begin{array}{l}\text { This subject } \\
\text { covers concepts of } \\
\text { sets, the real } \\
\text { number system, } \\
\text { concepts of } \\
\text { measurement, } \\
\text { algebraic } \\
\text { expressions, }\end{array}$ & $\begin{array}{l}\text { This subject } \\
\text { covers factors of } \\
\text { polynomials, } \\
\text { rational } \\
\text { algebraic } \\
\text { expressions, } \\
\text { linear equations, } \\
\text { inequalities in }\end{array}$ & $\begin{array}{l}\text { This subject } \\
\text { covers } \\
\text { quadratic } \\
\text { equations, } \\
\text { inequalities } \\
\text { and functions, } \\
\text { rational } \\
\text { algebraic }\end{array}$ & $\begin{array}{l}\text { This subject } \\
\text { covers } \\
\text { sequences, } \\
\text { polynomials, } \\
\text { polynomial } \\
\text { equations, } \\
\text { polynomial } \\
\text { function, }\end{array}$ \\
\hline
\end{tabular}




\begin{tabular}{|c|c|c|c|c|}
\hline \multicolumn{5}{|c|}{ The Junior High School (JHS) Core Curriculum } \\
\hline Grade Level & Grade 7 & Grade 8 & Grade 9 & Grade 10 \\
\hline $\begin{array}{c}\text { Learning } \\
\text { Area }\end{array}$ & \multicolumn{4}{|c|}{ Description } \\
\hline & $\begin{array}{l}\text { properties of real } \\
\text { numbers applied } \\
\text { in linear } \\
\text { equations, } \\
\text { inequalities in one } \\
\text { variable, concepts } \\
\text { of geometry, } \\
\text { shapes and sizes } \\
\text { and geometric } \\
\text { relationships, key } \\
\text { concepts of } \\
\text { statistics, data } \\
\text { representation, } \\
\text { measures of } \\
\text { central tendency, } \\
\text { and measures of } \\
\text { variability and } \\
\text { probability. }\end{array}$ & $\begin{array}{l}\text { two variables, } \\
\text { systems of linear } \\
\text { equations and } \\
\text { inequalities in } \\
\text { two variables, } \\
\text { linear functions, } \\
\text { linear } \\
\text { inequalities in } \\
\text { two variables, } \\
\text { systems of linear } \\
\text { inequalities in } \\
\text { two variables } \\
\text { and linear } \\
\text { functions, logic } \\
\text { and reasoning, } \\
\text { axiomatic } \\
\text { structure of } \\
\text { geometry and } \\
\text { triangle a } \\
\text { congruence, } \\
\text { inequality in a } \\
\text { triangle, parallel } \\
\text { and perpendicular } \\
\text { lines, and } \\
\text { probability. }\end{array}$ & $\begin{array}{l}\text { equations, } \\
\text { variation and } \\
\text { radicals, } \\
\text { quadrilaterals } \\
\text { (parallelogram } \\
\text { s, trapezoids, } \\
\text { kites), triangle } \\
\text { similarity, and } \\
\text { basic concepts } \\
\text { of } \\
\text { trigonometry. }\end{array}$ & $\begin{array}{l}\text { circles, } \\
\text { coordinate } \\
\text { geometry, } \\
\text { combinatorics, } \\
\text { probability, and } \\
\text { measures of } \\
\text { position. }\end{array}$ \\
\hline Science & $\begin{array}{l}\text { This subject } \\
\text { covers scientific } \\
\text { investigation; } \\
\text { materials in the } \\
\text { environment like } \\
\text { solutions, } \\
\text { substances and } \\
\text { mixtures; } \\
\text { elements and } \\
\text { compounds, acids } \\
\text { and bases, metals } \\
\text { and nonmetals; } \\
\text { microscopy, level } \\
\text { of biological } \\
\text { organization, } \\
\text { animal and plant } \\
\text { cells, fungi, } \\
\text { protists, and } \\
\text { bacteria; asexual } \\
\text { reproduction and } \\
\text { sexual } \\
\text { reproductions; } \\
\text { components of an }\end{array}$ & $\begin{array}{l}\text { This subject } \\
\text { covers laws of } \\
\text { motion, work, } \\
\text { power, and } \\
\text { energy; sound } \\
\text { light, heat, and } \\
\text { electricity; } \\
\text { earthquakes and } \\
\text { faults; } \\
\text { understanding } \\
\text { typhoons; other } \\
\text { members of the } \\
\text { solar system; the } \\
\text { particle nature of } \\
\text { matter; atomic } \\
\text { structure; } \\
\text { periodic table of } \\
\text { elements; } \\
\text { digestive system; } \\
\text { heredity, } \\
\text { including } \\
\text { inheritance and } \\
\text { variation of }\end{array}$ & $\begin{array}{l}\text { This subject } \\
\text { covers } \\
\text { respiratory } \\
\text { and } \\
\text { circulatory } \\
\text { systems } \\
\text { working with } \\
\text { the other } \\
\text { organ systems; } \\
\text { heredity, } \\
\text { including } \\
\text { inheritance } \\
\text { and variation; } \\
\text { biodiversity } \\
\text { and evolution, } \\
\text { ecosystems; } \\
\text { chemical } \\
\text { bonding; the } \\
\text { variety of } \\
\text { carbon } \\
\text { compounds; } \\
\text { mole concept; }\end{array}$ & $\begin{array}{l}\text { This subject } \\
\text { covers plate } \\
\text { tectonics; } \\
\text { electromagnetic } \\
\text { spectrum; light, } \\
\text { electricity, and } \\
\text { magnetism; } \\
\text { coordinated } \\
\text { functions of } \\
\text { reproductive, } \\
\text { endocrine, and } \\
\text { nervous } \\
\text { systems; } \\
\text { heredity, } \\
\text { including } \\
\text { inheritance and } \\
\text { variation; } \\
\text { biodiversity and } \\
\text { evolution; } \\
\text { ecosystems; } \\
\text { and gas laws, } \\
\text { biomolecules, } \\
\text { and }\end{array}$ \\
\hline
\end{tabular}




\begin{tabular}{|c|c|c|c|c|}
\hline \multicolumn{5}{|c|}{ The Junior High School (JHS) Core Curriculum } \\
\hline Grade Level & Grade 7 & Grade 8 & Grade 9 & Grade 10 \\
\hline $\begin{array}{c}\text { Learning } \\
\text { Area }\end{array}$ & \multicolumn{4}{|c|}{ Description } \\
\hline & $\begin{array}{l}\text { ecosystem; } \\
\text { ecological } \\
\text { relationships; } \\
\text { descriptors of } \\
\text { motion; motion } \\
\text { detectors; types of } \\
\text { waves, } \\
\text { characteristics of } \\
\text { waves, and wave } \\
\text { velocity; } \\
\text { characteristics of } \\
\text { sound and light; } \\
\text { heat transfer; and } \\
\text { charges } \\
\text { charging and } \\
\text { processes; using a } \\
\text { coordinate system; } \\
\text { protection and } \\
\text { conservation of } \\
\text { natural resources; } \\
\text { greenhouse effect } \\
\text { and global } \\
\text { warming; and land } \\
\text { and sea breezes, } \\
\text { monsoons, } \\
\text { intertropical } \\
\text { convergence zone, } \\
\text { seasons in the } \\
\text { Philippines, and } \\
\text { eclipses. }\end{array}$ & $\begin{array}{ll}\text { traits; } & \text { and } \\
\text { biodiversity } & \text { and } \\
\text { ecosystems. } & \end{array}$ & $\begin{array}{l}\text { volcanoes; } \\
\text { climate; } \\
\text { constellations, } \\
\text { motion in two } \\
\text { dimensions; } \\
\text { work power } \\
\text { and energy, } \\
\text { heat, work, } \\
\text { and efficiency; } \\
\text { and electricity } \\
\text { and } \\
\text { magnetism. }\end{array}$ & $\begin{array}{l}\text { chemical } \\
\text { reactions. }\end{array}$ \\
\hline $\begin{array}{l}\text { Araling } \\
\text { Panlipunan } \\
\text { (AP) }\end{array}$ & $\begin{array}{l}\text { This subject } \\
\text { focuses on Araling } \\
\text { Asyano (Asian } \\
\text { History). } \\
\text { Its topics include } \\
\text { katangiang pisikal } \\
\text { ng Asya at mga } \\
\text { likas na yaman ng } \\
\text { Asya; yamang-tao; } \\
\text { paghubog } \\
\text { sinaunang } \\
\text { kabihasnan sa } \\
\text { Asya, sinaunang } \\
\text { pamumuhay; } \\
\text { kolonyalismo at } \\
\text { imperyalismo sa } \\
\text { Timog at } \\
\text { Kanlurang Asya; }\end{array}$ & 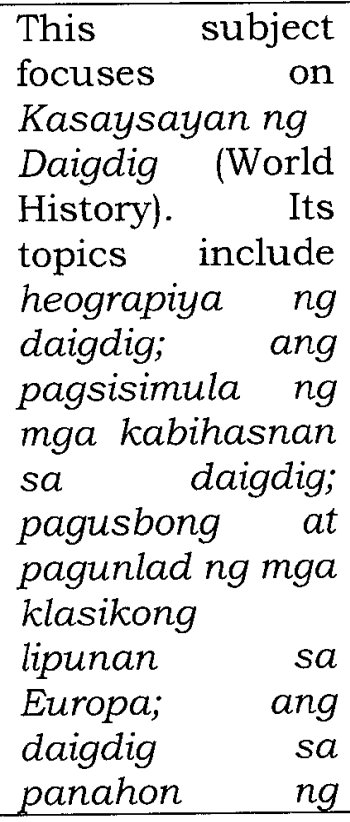 & $\begin{array}{l}\text { This subject } \\
\text { focuses on } \\
\text { Ekonomiks } \\
\text { (Economics). } \\
\text { Its topics } \\
\text { include } \\
\text { kahulugan ng } \\
\text { ekonomiks, } \\
\text { kakapusan, } \\
\text { pangangai- } \\
\text { langan, at } \\
\text { kagustuhan; } \\
\text { alokasyon, } \\
\text { pagkonsumo, } \\
\text { at } \\
\text { produksyon; } \\
\text { demand and } \\
\text { supply, } \\
\end{array}$ & $\begin{array}{l}\text { This subject } \\
\text { focuses on Mga } \\
\text { Kontemporaryo } \\
\text { ng Isyu at mga } \\
\text { Hamong } \\
\text { Panlipunan } \\
\text { (Contemporary } \\
\text { Issues). Its } \\
\text { topics include } \\
\text { kahalagahan ng } \\
\text { pag-aaral ng } \\
\text { mga } \\
\text { kontemporaryon } \\
\text { g isyu; mga } \\
\text { suliraning } \\
\text { pangkapaligiran } \\
\text { mga suliraning } \\
\text { mga }\end{array}$ \\
\hline
\end{tabular}




\begin{tabular}{|c|c|c|c|c|}
\hline \multicolumn{5}{|c|}{ The Junior High School (JHS) Core Curriculum } \\
\hline Grade Level & Grade 7 & Grade 8 & Grade 9 & Grade 10 \\
\hline Learning & \multicolumn{4}{|c|}{ Description } \\
\hline & $\begin{array}{l}\text { nasyonalismo at } \\
\text { paglaya ng mga } \\
\text { bansa sa Timog at } \\
\text { Kanlurang Asya; } \\
\text { mga pagbabago sa } \\
\text { Timog at } \\
\text { Kanlurang Asya; } \\
\text { kolonyalismo at } \\
\text { imperyalismo sa } \\
\text { Silangan at Timog } \\
\text { Silangang Asya; } \\
\text { nasyonalismo at } \\
\text { paglaya ng mga } \\
\text { bansa sa Silangan } \\
\text { at Timog Silangang } \\
\text { Asya; and mga } \\
\text { pagbabago sa } \\
\text { Silangan at Timog } \\
\text { Silangang Asya. }\end{array}$ & $\begin{array}{l}\text { transisyon; } \\
\text { paglakas ng } \\
\text { Europa at } \\
\text { paglawak ng } \\
\text { kapangyarihan } \\
\text { ng Europa; } \\
\text { pagkamulat, ang } \\
\text { unang digmaang } \\
\text { pandaigidig, at } \\
\text { ang ikalawang } \\
\text { digmaang } \\
\text { pandaigdig; mga } \\
\text { ideolohiya, Cold } \\
\text { War, at neo- } \\
\text { kolonyalismo; } \\
\text { and mga } \\
\text { pandaigdigang } \\
\text { organisasyon, } \\
\text { pangkat, at } \\
\text { alyansa. }\end{array}$ & $\begin{array}{l}\text { interaksyon } n g \\
\text { demand at } \\
\text { supply; } \\
\text { pamilihan; } \\
\text { paikot ng } \\
\text { daloy ng } \\
\text { ekonomiya, } \\
\text { pambansang } \\
\text { kita, ugnayan } \\
\text { ng kita, } \\
\text { pagiimpok, at } \\
\text { pagkonsumo; } \\
\text { implasyon, } \\
\text { patakarang } \\
\text { piskal, at } \\
\text { patakarang } \\
\text { pananalapi; } \\
\text { konsepto at } \\
\text { palatandaan } \\
\text { ng } \\
\text { pambansang } \\
\text { kaunlaran; } \\
\text { sektlor } \quad \text { ng } \\
\text { agrikultura, } \\
\text { sektor ng } \\
\text { industriya, } \\
\text { sektor ng } \\
\text { paglilingkod, } \\
\text { atimpormalna } \\
\text { sektor; and } \\
\text { kalakalang } \\
\text { panlabas. }\end{array}$ & $\begin{array}{l}\text { pangkapaligiran } \\
\text { sa sariling } \\
\text { pamayanan; } \\
\text { mga isyung } \\
\text { pang- } \\
\text { ekonomiya, mga } \\
\text { isyung pulitikal, } \\
\text { mga isyu sa } \\
\text { karapatang } \\
\text { pantao, mga } \\
\text { isyu na may } \\
\text { kaugnayan sa } \\
\text { kasarian } \\
\text { (gender), at mga } \\
\text { isyung pang- } \\
\text { edukasyon. }\end{array}$ \\
\hline $\begin{array}{l}\text { Edukasyon sa } \\
\text { Pagpapakatao } \\
\text { (EsP) }\end{array}$ & $\begin{array}{l}\text { This subject } \\
\text { covers mga angkop } \\
\text { na inaasahang } \\
\text { kakayahan at kilos } \\
\text { sa panahon ng } \\
\text { pagdadalaga/ } \\
\text { pagbibinata; mga } \\
\text { talent at } \\
\text { kakayahan; } \\
\text { mga hilig } \\
\text { (interests); mga } \\
\text { tungkulin bilang } \\
\text { nagdadalaga at } \\
\text { nagbibinata; isip at } \\
\text { kilos loob (will); } \\
\text { ang kaugnayan ng } \\
\text { konsiyensiya sa }\end{array}$ & $\begin{array}{lr}\text { This } & \text { subject } \\
\text { coversang } & \\
\text { pamilya bilang } \\
\text { natural } & \text { na } \\
\text { institusyon } & n g \\
\text { lipunan, } & \text { ang } \\
\text { misyon r } & n g \\
\text { pamilya r } & \text { sa } \\
\text { pagbibigay } & \text { ng } \\
\text { edukasyon; } & \\
\text { paggabay } & \text { sa } \\
\text { pagpapasiya } & \text { at } \\
\text { paghubog ng } & \\
\text { pananampalatay } \\
\text { a; } \\
\text { ang panlipunan } \\
\text { at pampulitikal }\end{array}$ & $\begin{array}{l}\text { This subject } \\
\text { covers layunin } \\
\text { ng lipunan: } \\
\text { kabutihang } \\
\text { panlahat, } \\
\text { lipunang } \\
\text { pulitikal, } \\
\text { lipunang } \\
\text { ekonomiya, } \\
\text { lipunang sibil; } \\
\text { media at } \\
\text { simbahan; at } \\
\text { karapatan at } \\
\text { tungkulin; mga } \\
\text { batas na } \\
\text { nakabatay sa } \\
\text { likas na batas } \\
\end{array}$ & $\begin{array}{lr}\text { This } & \text { subject } \\
\text { covers ang } \\
\text { mataas na } \\
\text { gamit nat } \\
\text { tunguhin ng isip } \\
\text { at kilos-loob } \\
\text { (will); paghubog } \\
\text { ng konsiyensiya } \\
\text { batay sa likas } \\
\text { nabatas moral; } \\
\text { ang tunay na } \\
\text { kalayaan, } \\
\text { dignidad, ang } \\
\text { pagkukusa ng } \\
\text { makataong kilos } \\
\text { (voluntariness } \\
\text { of human act); }\end{array}$ \\
\hline
\end{tabular}




\begin{tabular}{|c|c|c|c|c|}
\hline \multicolumn{5}{|c|}{ The Junior High School (JHS) Core Curriculum } \\
\hline Grade Level & Grade 7 & Grade 8 & Grade 9 & Grade 10 \\
\hline $\begin{array}{c}\text { Learning } \\
\text { Area }\end{array}$ & & Descript & on & \\
\hline & 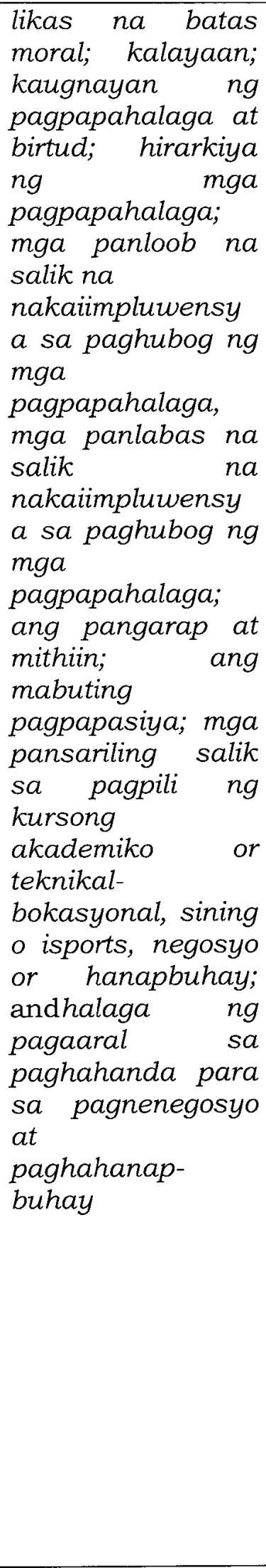 & 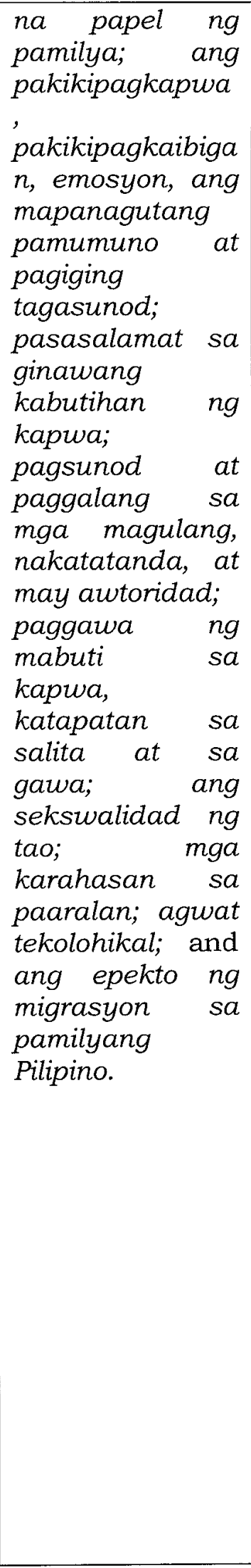 & $\begin{array}{l}\text { moral (natural } \\
\text { law); ang } \\
\text { paggawa } \\
\text { bilang } \\
\text { paglilingkod at } \\
\text { pagtataguyod } \\
\text { ng dignidadng } \\
\text { tao; } \\
\text { pakikilahok at } \\
\text { bolunterismo; } \\
\text { katarungang } \\
\text { panlipunan; } \\
\text { kagalingan sa } \\
\text { paggawa; } \\
\text { kasipagan, } \\
\text { pagpupunyagi } \\
\text { pagtitipid at } \\
\text { wastong } \\
\text { pamamahala } \\
\text { sa naimpok, } \\
\text { pamamahala } \\
\text { ng paggamit } \\
\text { ng oras; mga } \\
\text { pansatiling } \\
\text { salik } \\
\text { pagpili } \quad \text { na } \\
\text { tamang } \\
\text { kursong } \\
\text { akademiko o } \\
\text { teknikal- } \\
\text { bokasyunal, } \\
\text { sining at } \\
\text { isports, } \\
\text { negosyo o } \\
\text { hanapbuhay; } \\
\text { mga local at } \\
\text { global } \\
\text { demand; and } \\
\text { paghahanda } \\
\text { sa } \\
\text { minimithing } \\
\text { uri } \\
\text { pamumuhay. }\end{array}$ & $\begin{array}{l}\text { mga salik na } \\
\text { nakaaapekto sa } \\
\text { pananagutan ng } \\
\text { tao sa } \\
\text { kahihinatnan ng } \\
\text { kilos at pasya; } \\
\text { mga yugto ng } \\
\text { makataong } \\
\text { kilos, layunin, } \\
\text { paraan, at } \\
\text { sirkumstansya } \\
\text { ng makataong } \\
\text { kilos; } \\
\text { pagmamahal sa } \\
\text { Diyos, } \\
\text { paggalang sa } \\
\text { buhay, } \\
\text { pagmamahal sa } \\
\text { bayan, } \\
\text { pangangalaga } \\
\text { sa kalikasan; } \\
\text { ang paninidigan } \\
\text { ng tao sa } \\
\text { pagmamahal } \\
\text { niya sa buhay } \\
\text { bilang kaloob ng } \\
\text { Diyos, } \\
\text { paninindigan sa } \\
\text { tamang } \\
\text { paggamit ng } \\
\text { kapangyarihan } \\
\text { at pangangalaga } \\
\text { pan kapaligiran, } \\
\text { sa kaninindigan } \\
\text { tungkol } \\
\text { pangangalaga } \\
\text { ng sarili laban } \\
\text { sa pang } \\
\text { aabusong tungo } \\
\text { seskwal maayos na } \\
\text { sa matingin sa } \\
\text { pagti } \\
\text { sarili } \\
\text { pagtataguyod } \\
\text { ng dignidad ng } \\
\text { paninidigan } \\
\text { para }\end{array}$ \\
\hline
\end{tabular}




\begin{tabular}{|c|c|c|c|c|}
\hline \multicolumn{5}{|c|}{ The Junior High School (JHS) Core Curriculum } \\
\hline Grade Level & Grade 7 & Grade 8 & Grade 9 & Grade 10 \\
\hline $\begin{array}{l}\text { Learning } \\
\text { Area }\end{array}$ & \multicolumn{4}{|c|}{ Description } \\
\hline & & & & katotohanan. \\
\hline Music & $\begin{array}{l}\text { This subject } \\
\text { covers music of } \\
\text { Luzon, Cordillera, } \\
\text { Mindoro, Palawan, } \\
\text { the Visayas, and } \\
\text { Mindanao, and } \\
\text { Philippine festivals } \\
\text { and theatrical } \\
\text { forms. }\end{array}$ & $\begin{array}{l}\text { This subject } \\
\text { covers music of } \\
\text { Southeast Asia, } \\
\text { East Asia, South } \\
\text { Asia, and the } \\
\text { Middle East, and } \\
\text { traditional Asian } \\
\text { theater music. }\end{array}$ & $\begin{array}{l}\text { This subject } \\
\text { covers music } \\
\text { of the } \\
\text { Medieval, } \\
\text { Renaissance, } \\
\text { and Classical } \\
\text { periods, and } \\
\text { instrumental } \\
\text { and vocal } \\
\text { music of the } \\
\text { Romantic } \\
\text { period. }\end{array}$ & $\begin{array}{l}\text { This subject } \\
\text { covers } \\
\text { impressionism, } \\
\text { expressionism, } \\
\text { electronic } \\
\text { music, chance } \\
\text { music, Afro- } \\
\text { Latin and } \\
\text { popular music, } \\
\text { contemporary } \\
\text { Philippine } \\
\text { music, } \\
\text { traditional } \\
\text { composers, new } \\
\text { music, song } \\
\text { composer, and } \\
\text { 20th - and 21st } \\
\text {-century } \\
\text { multimedia } \\
\text { forms including } \\
\text { opera, ballet, } \\
\text { and the } \\
\text { musical. }\end{array}$ \\
\hline $\begin{array}{l}\text { Physical } \\
\text { Education }\end{array}$ & $\begin{array}{l}\text { This subject } \\
\text { covers exercise } \\
\text { programs, training } \\
\text { guidelines, FITT } \\
\text { Principles and } \\
\text { endurance; and } \\
\text { muscle- and bone- } \\
\text { strengthening } \\
\text { activities through } \\
\text { individual } \\
\text { (running, } \\
\text { rhythmic sportive } \\
\text { gymnastics, } \\
\text { swimming), dual } \\
\text { (badminton, table } \\
\text { tennis, tennis), } \\
\text { and combative } \\
\text { (arnis, taekwondo, } \\
\text { karate) sports; and } \\
\text { folk/ethnic, } \\
\text { indigenous, } \\
\text { traditional festival } \\
\text { dances. }\end{array}$ & $\begin{array}{l}\text { This subject } \\
\text { covers exercise } \\
\text { programs, } \\
\text { training } \\
\text { guidelines, FITT } \\
\text { Principles and } \\
\text { endurance; } \\
\text { muscle- and } \\
\text { bone- } \\
\text { strengthening } \\
\text { activities } \\
\text { through team } \\
\text { sports } \\
\text { (basketball, } \\
\text { volleyball, } \\
\text { football/futsal, } \\
\text { goalball, softball, } \\
\text { baseball); and } \\
\text { folk dances with } \\
\text { Asian influences. }\end{array}$ & $\begin{array}{l}\text { This subject } \\
\text { covers lifestyle } \\
\text { and weight } \\
\text { management; } \\
\text { sports } \\
\text { officiating; } \\
\text { social } \\
\text { (community } \\
\text { dance, mixers, } \\
\text { festival) and } \\
\text { ballroom (cha- } \\
\text { cha, rock and } \\
\text { roll) dances; } \\
\text { and active } \\
\text { recreation, } \\
\text { including both } \\
\text { indoor } \\
\text { (individual } \\
\text { and dual } \\
\text { sports, team } \\
\text { sports, } \\
\text { dances,) and } \\
\text { outdoor } \\
\text { (hiking, } \\
\text { camping, }\end{array}$ & $\begin{array}{l}\text { This subject } \\
\text { covers lifestyle } \\
\text { and weight } \\
\text { management; } \\
\text { active } \\
\text { recreation } \\
\text { (sports), } \\
\text { including } \\
\text { individual and } \\
\text { dual sports, } \\
\text { team sports, } \\
\text { fitness activities } \\
\text { (strength } \\
\text { training, } \\
\text { running and } \\
\text { walking for } \\
\text { fitness, yoga, } \\
\text { group exercises), and } \\
\text { oxther dance } \\
\text { forms (hip-hop, } \\
\text { street dance, } \\
\text { cheer dance, } \\
\text { contemporary } \\
\text { dance). }\end{array}$ \\
\hline
\end{tabular}




\begin{tabular}{|c|c|c|c|c|}
\hline \multicolumn{5}{|c|}{ The Junior High School (JHS) Core Curriculum } \\
\hline Grade Level & Grade 7 & Grade 8 & Grade 9 & Grade 10 \\
\hline $\begin{array}{c}\text { Learning } \\
\text { Area }\end{array}$ & \multicolumn{4}{|c|}{ Description } \\
\hline & & & $\begin{array}{l}\text { orienteering, } \\
\text { biking) } \\
\text { activities. }\end{array}$ & \\
\hline Health & $\begin{array}{l}\text { This subject } \\
\text { covers holistic } \\
\text { health; stages of } \\
\text { growth and } \\
\text { development } \\
\text { (infancy to old } \\
\text { age); changes in } \\
\text { the health } \\
\text { dimensions during } \\
\text { adolescence, } \\
\text { management of } \\
\text { health concerns } \\
\text { during adolescence; } \\
\text { adole } \\
\text { health of } \\
\text { appraisal } \\
\text { procedures; } \\
\text { development of } \\
\text { self-awareness } \\
\text { and coping skills; } \\
\text { nutrition during } \\
\text { adolescence, } \\
\text { nutritional } \\
\text { guidelines, } \\
\text { nutrition problems } \\
\text { of adolescents; } \\
\text { decision-making } \\
\text { skills, mental } \\
\text { health } \\
\text { introduction), } \\
\text { understanding } \\
\text { stress, common } \\
\text { stressors affecting } \\
\text { adolescents, } \\
\text { coping with stress; } \\
\text { coping with dying } \\
\text { and death; types } \\
\text { and management } \\
\text { of common mental } \\
\text { disorders; } \\
\text { introduction to } \\
\text { noncommunicable } \\
\text { diseases (NCDs), } \\
\text { common NCDs, } \\
\text { prevention and } \\
\text { control of NCDs, }\end{array}$ & $\begin{array}{l}\text { This subject } \\
\text { covers gender } \\
\text { and human } \\
\text { sexuality; } \\
\text { teenage } \\
\text { concerns, } \\
\text { including crisis, } \\
\text { identity identity, } \\
\text { sexual sexual } \\
\text { and sex, } \\
\text { behaviors; } \\
\text { premarital sex, } \\
\text { teenage } \\
\text { pregnancies, and } \\
\text { abortion; } \\
\text { development of } \\
\text { decision-making } \\
\text { skills is } \\
\text { managing } \\
\text { sexuality-related } \\
\text { issues, dating, } \\
\text { courtship, and } \\
\text { marriage; } \\
\text { maternal health } \\
\text { concerns, } \\
\text { responsible } \\
\text { parenthood, and } \\
\text { stages of } \\
\text { infection; top 10 } \\
\text { leading causes of } \\
\text { morbidity and } \\
\text { mortality in the } \\
\text { Philippines; } \\
\text { most common } \\
\text { communicable } \\
\text { diseases and } \\
\text { their prevention } \\
\text { and control; } \\
\text { emerging and re- } \\
\text { emerging } \\
\text { diseases; } \\
\text { development of } \\
\text { personal life } \\
\text { skills to prevent } \\
\text { and control } \\
\text { communicable }\end{array}$ & $\begin{array}{l}\text { This subject } \\
\text { covers } \\
\text { concepts of } \\
\text { community } \\
\text { and } \\
\text { environmental } \\
\text { health, } \\
\text { prevention } \\
\text { and } \\
\text { management } \\
\text { of en } \\
\text { environmental } \\
\text { health, and } \\
\text { collective } \\
\text { action for the } \\
\text { environment; } \\
\text { drug scenario } \\
\text { in the } \\
\text { Philippines, } \\
\text { factors that } \\
\text { influence } \\
\text { substance use } \\
\text { and abuse, } \\
\text { drugs or or } \\
\text { substances of } \\
\text { abuse, } \\
\text { harmful } \\
\text { effects of of } \\
\text { drugs on the } \\
\text { body, } \\
\text { prevention } \\
\text { and control of } \\
\text { substance use } \\
\text { and abuse; } \\
\text { first aid } \\
\text { basics, first } \\
\text { aid guidelines } \\
\text { and por } \\
\text { procedures, } \\
\text { use } \\
\text { dressing and } \\
\text { bandages, } \\
\text { transporting } \\
\text { the } \\
\text { first aid for } \\
\text { common }\end{array}$ & $\begin{array}{l}\text { This subject } \\
\text { covers } \\
\text { guidelines and } \\
\text { criteria in the } \\
\text { selection and } \\
\text { evaluation of } \\
\text { health } \\
\text { information, } \\
\text { health } \\
\text { products, and } \\
\text { health services; } \\
\text { health service } \\
\text { providers and } \\
\text { types of } \\
\text { quackery and } \\
\text { their harmful } \\
\text { physical and } \\
\text { psychological } \\
\text { effects; } \\
\text { complementary } \\
\text { and alternative } \\
\text { healthcare } \\
\text { modalities; } \\
\text { consumer } \\
\text { welfare and } \\
\text { protection; } \\
\text { existing } \\
\text { national laws } \\
\text { related to health } \\
\text { trends, issues, } \\
\text { and } \\
\text { concerns; global } \\
\text { existing } \\
\text { health and } \\
\text { initiatives; and } \\
\text { planning for a } \\
\text { career related to } \\
\text { health. }\end{array}$ \\
\hline
\end{tabular}




\begin{tabular}{|c|c|c|c|c|}
\hline \multicolumn{5}{|c|}{ The Junior High School (JHS) Core Curriculum } \\
\hline Grade Level & Grade 7 & Grade 8 & Grade 9 & Grade 10 \\
\hline Learning & \multicolumn{4}{|c|}{ Description } \\
\hline & $\begin{array}{l}\text { self-monitoring } \\
\text { skills to prevent } \\
\text { NCDs, programs } \\
\text { and policies on } \\
\text { NCD prevention } \\
\text { and control, and } \\
\text { agencies } \\
\text { responsible for } \\
\text { NCD prevention } \\
\text { and control. }\end{array}$ & $\begin{array}{l}\text { diseases; } \\
\text { programs and } \\
\text { policies on } \\
\text { communicable } \\
\text { diseases } \\
\text { prevention and } \\
\text { control, agencies } \\
\text { responsible for } \\
\text { communicable } \\
\text { diseases } \\
\text { prevention and } \\
\text { control; gateway } \\
\text { drugs, protective } \\
\text { and risk factors } \\
\text { in the use of } \\
\text { cigarettes and } \\
\text { alcohol, and } \\
\text { prevention and } \\
\text { control gat of } \\
\text { gateway drugs. }\end{array}$ & $\begin{array}{l}\text { unintentional } \\
\text { injuries and } \\
\text { medical } \\
\text { emergencies; } \\
\text { concept of } \\
\text { intentional } \\
\text { injuries, types } \\
\text { of intentional } \\
\text { injuries, and } \\
\text { prevention } \\
\text { and } \\
\text { management } \\
\text { of intentional } \\
\text { injuries. }\end{array}$ & \\
\hline
\end{tabular}

20. One thing unique to the JHS is the nature of Technology and Livelihood Education (TLE) as a learning area which is consistent with the Technical Education and Skills Development Authority (TESDA) Training Regulations (TR). In Grades 7 and 8 , TLE is exploratory while still covering the basic competencies of one component each semester. For example, Home Economics with Entrepreneurship for Grade 7 first semester; Agri-Fishery Arts with Entrepreneurship for the second semester; Industrial Arts with Entrepreneurship for Grade 8 first semester and ICT with Entrepreneurship for the second semester. Learners are taught the following five common competencies, namely: 1) use of tools and equipment, 2) maintenance of tools and equipment, 3) reading and interpreting drawings and plans, 4) mensuration and calculation, and 5) maintaining safety in the workplace. All of these common competencies are taught in the context of the offered exploratory TLE. For example, the use and maintenance of tools in the ICT are different from those in Carpentry under Industrial Arts (IA).

21. In Grades 9 and 10, JHS learners choose a specialization from the exploratory TLE areas offered by the school, with entrepreneurship integrated. This will prepare them for the attainment of a National Certificate (NC) from TESDA. In TLE, ICT is taught as a subject, which is a continuation of the teaching of ICT in Edukasyong Pantahanan at Pangkabuhayan (EPP) in Grades 4, 5 and 6. Unlike in other learning areas, ICT is a stand-alone subject in TLE and is not merely integrated into the learning area. Moreover, ICT has 12 specializations in TLE in which a junior high school learner can obtain an NC.

22. Another important feature of the JHS curriculum is the provision of two (2) to four (4) hours per week for independent or cooperative learning. The purpose is to develop learners' capacity for self-directed learning, teamwork, goal orientation, and learners' sense of responsibility or accountability for their learning. This is a 
time provided for JHS learners to study on their own or with others topics, content, or processes that they can handle by themselves. This dovetails with their expected development of an increasing degree of independence in applying knowledge, skills, and values learned as shown across the various levels of the Philippine Qualifications Framework (PQF). This may be scheduled at the start, middle, or end of the day. The school is given flexibility to schedule the period and the hours for independent learning, but it should not be less than two hours per week.

23. The JHS curriculum also utilizes the spiral progression approach. This is clearly demonstrated in the teaching of Mathematics and Science. The fundamentals of all branches of Mathematics (algebra, geometry, trigonometry, statistics, and probability) and Science (biology, chemistry, physics, and earth science) are taught and revisited from Grades 7 to 10 and become more sophisticated from one grade level to the next.

24. The other subjects are also taught using the spiral progression approach in the sense that the content and performance standards that are unpacked further into competencies are vertically articulated. What is taught in Grade 7 connects to what is taught in Grades 8, 9, and 10. Another feature of the JHS is that the total time in the sample class program excludes the expected offschool learning experiences which teachers may require outside of school hours for the creation of products and/or performance as evidence of the transfer of learning. These pieces of evidence of learning transfer usually take the form of a culminating activity at the end of the quarter, which is another interesting feature of the JHS curriculum. Table 2.3 presents the time allotment for the eight (8) learning areas in $\mathrm{K}$ to $12 \mathrm{JHS}$.

Table 2.3: The Eight Learning Areas in Junior High School (JHS) with Respective Time Allotment

\begin{tabular}{|l|l|}
\hline \multirow{2}{*}{\multicolumn{1}{|c|}{ Learning Areas }} & \multicolumn{1}{c|}{$\begin{array}{c}\text { TIME } \\
\text { ALLTMENT }\end{array}$} \\
\cline { 2 - 2 } & $\begin{array}{c}\text { Number of } \\
\text { minutes per week }\end{array}$ \\
\hline English & 240 \\
\hline Math & 240 \\
\hline Filipino & 240 \\
\hline Science & 240 \\
\hline Araling Panlipunan (AP) & 180 \\
\hline Edukasyon sa Pagpapakatao (EsP) & 120 \\
\hline Music, Arts, Physical Education and Health (MAPEH) & 240 \\
\hline Technology and Livelihood Education (TLE) & 240 \\
\hline Homeroom Guidance Program & 60 \\
\hline Special Curricular Programs & 240 \\
\hline NOTE: Independent or Cooperative learning is given two hours per week. \\
\hline
\end{tabular}

25. In addition to the Learning Areas that require two to four hours per week, Junior High School classes should have an hour allotted for the Homeroom Guidance Program and four hours per week allotted for Special Curricular Programs (SCP). Learners taking up a Special Interest Program will have 2 hours of TLE contextualized on the Special Program chosen. Details of the Homeroom Guidance Program and the Special Curricular Programs (SCP) will be discussed further in 
separate policy issuances. Clubs should meet for an hour twice a month as well. Details on clubs will be released in a separate issuance. The time allotted for Independent or Cooperative Learning which is 2 hours per week may be used for individual work, research/review/library time.

26. In Grade 9, selected learners may be trained to be officers and leaders of their grade level for their Citizenship Training Program (CTP) in Grade 10. Grade 10 learners have CTP for an hour per week. A separate CTP policy issuance will also be released.

27. The medium of teaching and learning used in Grades 7 to 10 are Filipino and English. The learning areas taught in these languages are shown in Table 2.4

Table 2.4: Medium of Teaching and Learning in Grades 7 to 10

\begin{tabular}{|c|c|c|c|c|}
\hline $\begin{array}{l}\text { Medium of } \\
\text { Teaching } \\
\text { and } \\
\text { Learning }\end{array}$ & Grade 7 & Grade 8 & Grade 9 & Grade 10 \\
\hline English & \multicolumn{4}{|c|}{$\begin{array}{l}\text { English } \\
\text { Science } \\
\text { Math } \\
\text { Music } \\
\text { Arts } \\
\text { PE } \\
\text { TLE }\end{array}$} \\
\hline Filipino & \multicolumn{4}{|c|}{$\begin{array}{c}\text { Filipino } \\
\text { Araling Panlipunan } \\
\text { Edukasyon sa Pagpapakatao }\end{array}$} \\
\hline
\end{tabular}

\section{B. Assessment in JHS}

28. Assessment in JHS includes formative and summative classroom assessments that are given during Grades 7 to 10 to improve student learning outcomes. Policies on assessment in the K to 12 such as DO 8, s. 2015 and DO 36, s. 2016 shall be referred to when conducting assessments in JHS.

29. At Grade 9, learners take the National Career Aptitude Examination (NCAE). The NCAE is an aptitude test meant to provide information through test results for self-assessment, career awareness, and career guidance of high school students for their post-secondary courses or application for scholarship. Test taking is mandatory but test results are recommendatory.

30. Learners may also undergo technical-vocational assessment through TESDA for a National Certificate. Those who finish JHS also have to take an exit assessment at Grade 10, which is the National Achievement Test (NAT) Grade 10.

\section{Key Stage 4: Senior High School}

31. The additional two (2) years to the basic education cycle is one of the hallmarks of the K to 12 program. The Senior High School (SHS) curriculum is the main policy tool that will serve as the blueprint for program implementation. This 
section aims to provide a concise yet comprehensive articulation of critical elements of the curriculum to ensure effectiveness and efficiency in program implementation.

32. The SHS curriculum is also DepEd's contribution to the ongoing articulation of a national system of quality assurance, accreditation, credit transfer, and recognition of learning pathways across the subsystems of Philippine education. Through the SHS curriculum, DepEd is able to formulate the equivalent qualification standards of basic education graduates vis-à-vis vocational-technical and higher education qualification standards. The SHS curriculum formulation, therefore, is a step toward the realization of the Philippine Qualifications Framework (PQF). As mentioned above, the SHS curriculum is the main policy tool for the implementation of the new 13-year cycle of basic education. The curriculum is composed of the Core, Applied Track, and Specialized Subjects, which are defined in the succeeding sections. There are 31 subjects in all, accounting for 2,480 hours in 2 years of senior high school. These are distributed in 4 semesters with 2 quarters per semester. The 15 compulsory subjects across eight Learning Areas in the Core Curriculum are described in Table 2.5 .

33. The SHS curriculum establishes the learning standards per learning area and the expected competencies that will be acquired by the learners per grade level and key stage outcome (Grade 12 for SHS). Essentially, a learning standard defines a core of knowledge and skills that students ought to acquire at different grade levels or over certain grade spans. It refers to how well the student must perform, at what kinds of tasks, and based on what content. It shall be used as a reference point for planning teaching and learning programs, and for assessing student progress. Hence, these learning standards shall also be the bases to ensure quality in the ongoing development of learning resources, i.e. the teachers' guides (TGs) and learners' materials (LMs). The SHS curriculum follows the following learning standards: 1) key stage standards, 2) learning area standards per grade level, 3) content standards, 4) performance standards, and 5) learning competencies.

34. Setting learning standards are triggered by different demands across sectors. For instance, as national economies evolve, global enterprises need more workers with higher levels of technological, academic, and work skills in order for industries to compete globally. School and workplace learning must address these through reforms in the curriculum and training programs.

35. Meanwhile, many parents around the world are worried that their children will not be prepared for further schooling or work and have started lobbying for higher educational standards. Thus, according to the 2012 Talent Shortage Survey conducted by a US think tank, these competency requirements will have to be addressed by a standards-based curriculum, i.e. one that empowers learners to identify and solve complex problems, encourages them to think independently and to work with teams, and to exhibit the traits of leaders no matter what their job in an organization.

36. For DepEd, articulating these learning standards is a means to communicate the purpose and intended results of the Enhanced BEP (K to 12) to the public, especially the SHS program. At the school level, it can serve as a guide to organize and share curriculum, assessments, and instructional methods among teachers across grade levels. For school heads, it can be a guide to focus school improvement plans to improve quality of teaching and learning. An extensive discussion of these learning standards per learning area and grade level can be found on the DepEd website. This volume provides a snapshot of the different components 
of SHS and descriptions of subject offerings, from the core to specialized subjects across the different tracks.

\section{A. The SHS Core Curriculum Subjects}

37. The Core Subjects in the SHS Curriculum ensure that all learners will be equipped with competencies required for specialization studies in their chosen SHS tracks. These subjects are contiguous to the $\mathrm{K}$ to 10 subjects and are responsive to the College Readiness Standards and New General Education Curriculum for Higher Education formulated by the Commission of Higher Education (CHED). Every subject in the Core Curriculum is compulsory and has a time allocation of 80 hours per semester except for PE and Health, which have 20 hours per semester. However, a maximum of 2 SHS core subjects may be substituted with equivalent subjects with the approval of DepEd.

Table 2.5: SHS Core Curriculum Subjects*

\begin{tabular}{|c|c|c|}
\hline \multicolumn{3}{|c|}{ THE CORE CURRICULUM } \\
\hline Learning Area & Subject & Description \\
\hline \multirow{4}{*}{ Language } & $\begin{array}{l}\text { Oral } \\
\text { Communication }\end{array}$ & $\begin{array}{l}\text { This subject covers the development of } \\
\text { listening and speaking skills and strategies } \\
\text { for effective communication in various } \\
\text { situations. }\end{array}$ \\
\hline & $\begin{array}{l}\text { Reading and } \\
\text { Writing }\end{array}$ & $\begin{array}{l}\text { This subject covers the development of } \\
\text { reading and writing skills as applied to a } \\
\text { wide range of materials other than poetry, } \\
\text { fiction, and drama. }\end{array}$ \\
\hline & $\begin{array}{l}\text { Komunikasyon at } \\
\text { Pananaliksik sa } \\
\text { Wika at } \\
\text { Kulturang Filipino }\end{array}$ & $\begin{array}{l}\text { Ito ay pag-aaral tungo sa pananaliksik ukol } \\
\text { sa kalikasan, katangian, pag-unlad, gamit at } \\
\text { paggamit ng Wikang Filipino sa mga } \\
\text { sitwasyong komunikatibo at kultural sa } \\
\text { lipunang Pilipino. }\end{array}$ \\
\hline & $\begin{array}{l}\text { Pagbasa at } \\
\text { Pagsuring Iba't- } \\
\text { ibang Teksto } \\
\text { Tungo sa } \\
\text { Pananaliksik } \\
\end{array}$ & $\begin{array}{l}\text { Ito ay pag-aaral sa proseso ng pagbasa at } \\
\text { pagsuri ng iba't ibang anyo at uri ng teksto } \\
\text { na nakatutulong sa pagbuo at pagsulat ng } \\
\text { sistematikong pananaliksik. }\end{array}$ \\
\hline \multirow[b]{2}{*}{ Humanities } & $\begin{array}{l}21 \text { st-century } \\
\text { Literature from } \\
\text { the Philippines } \\
\text { and the World }\end{array}$ & $\begin{array}{l}\text { This subject covers the appreciation and } \\
\text { critical study of } 21 \text { st Century Literature } \\
\text { from the Philippines and the World } \\
\text { encompassing their various dimensions, } \\
\text { genres, elements, structures, contexts, and } \\
\text { traditions. }\end{array}$ \\
\hline & $\begin{array}{l}\text { Contemporary } \\
\text { Philippine Arts } \\
\text { from the Regions }\end{array}$ & $\begin{array}{l}\text { This subject covers various contemporary } \\
\text { art practices of the region where the school } \\
\text { is located. It aims to provide students with } \\
\text { an appreciation of a broad range of styles in } \\
\text { the various disciplines with consideration } \\
\text { for their elements and principles, and } \\
\text { engage them in an integrative approach in } \\
\text { the study of the arts. It also aims to broaden } \\
\text { the students' mindsets so that they could } \\
\text { acquire the necessary creative tools which }\end{array}$ \\
\hline
\end{tabular}




\begin{tabular}{|c|c|c|}
\hline \multicolumn{3}{|c|}{ THE CORE CURRICULUM } \\
\hline Learning Area & Subject & $\begin{array}{l}\text { Description } \\
\end{array}$ \\
\hline & & $\begin{array}{l}\text { open opportunities in the pursuit of } \\
\text { individual career goals and aspirations. }\end{array}$ \\
\hline Communication & $\begin{array}{l}\text { Media and } \\
\text { Information } \\
\text { Literacy }\end{array}$ & $\begin{array}{l}\text { This subject introduces the learners to a } \\
\text { basic understanding of media and } \\
\text { information as channels of communication } \\
\text { and tools for individual and social } \\
\text { development. It also aims to develop the } \\
\text { learners' creative and critical thinking, and } \\
\text { encourage them to be responsible users and } \\
\text { competent producers of media and } \\
\text { information. }\end{array}$ \\
\hline \multirow[b]{2}{*}{ Mathematics } & $\begin{array}{l}\text { General } \\
\text { Mathematics }\end{array}$ & $\begin{array}{l}\text { This subject covers the following } \\
\text { competencies: how to solve problems } \\
\text { involving rational, exponential, and } \\
\text { logarithmic functions; how to solve } \\
\text { business-related problems; and how to } \\
\text { apply logic to real-life situations. }\end{array}$ \\
\hline & $\begin{array}{l}\text { Statistics and } \\
\text { Probability }\end{array}$ & $\begin{array}{l}\text { This subject covers the following } \\
\text { competencies: how to find the mean and } \\
\text { variance of a random variable; how to apply } \\
\text { sampling techniques and distributions to } \\
\text { estimate population mean and proportion; } \\
\text { how to perform hypothesis testing on } \\
\text { population mean and proportion; and how to } \\
\text { perform correlation and regression analyses } \\
\text { on real-life problems. }\end{array}$ \\
\hline \multirow[t]{2}{*}{ Science } & $\begin{array}{l}\text { Earth and Life } \\
\text { Science }\end{array}$ & $\begin{array}{l}\text { This subject is designed to provide a general } \\
\text { background for the understanding of Earth } \\
\text { Science and Biology. It presents the history } \\
\text { of the Earth through geologic time. It } \\
\text { discusses the Earth's structure, } \\
\text { composition, and processes. Issues, } \\
\text { concerns, and problems pertaining to } \\
\text { natural hazards are also included. It also } \\
\text { deals with the basic principles and } \\
\text { processes in the study of Biology. It covers } \\
\text { life processes and interactions at the } \\
\text { cellular, organism, population, and } \\
\text { ecosystem levels. }\end{array}$ \\
\hline & Physical Science & $\begin{array}{l}\text { This subject covers the study of the } \\
\text { following: evolution of our understanding of } \\
\text { matter, motion, electricity, magnetism, light, } \\
\text { and the universe from ancient times to the } \\
\text { present; applications of physics and } \\
\text { chemistry concepts in contexts such as } \\
\text { atmospheric phenomena, cosmology, } \\
\text { astronomy, vision, medical instrumentation, } \\
\text { space technology, drugs, sources of energy, } \\
\text { pollution and recycling, fitness and health, } \\
\text { and cosmetics. }\end{array}$ \\
\hline
\end{tabular}




\begin{tabular}{|c|c|c|}
\hline \multicolumn{3}{|c|}{ THE CORE CURRICULUM } \\
\hline Learning Area & Subject & Description \\
\hline \multirow[t]{2}{*}{ Social Science } & $\begin{array}{l}\text { Personal } \\
\text { Development }\end{array}$ & $\begin{array}{l}\text { This subject facilitates students' awareness } \\
\text { of the developmental stage that they are in, } \\
\text { in order to better understand themselves } \\
\text { and their significant persons as they make } \\
\text { important life and career decisions. The } \\
\text { course consists of modules, each of which } \\
\text { addresses a key concern in personal } \\
\text { development. Using the experiential learning } \\
\text { approach, each module allows the students } \\
\text { to explore specific themes in their } \\
\text { development. }\end{array}$ \\
\hline & $\begin{array}{l}\text { Understanding } \\
\text { Culture, Politics, } \\
\text { and Society }\end{array}$ & $\begin{array}{l}\text { This subject uses insights from } \\
\text { Anthropology, Political Science, and } \\
\text { Sociology to develop students' awareness of } \\
\text { social and political dynamics, and sensitivity } \\
\text { to cultural differences; provide them with an } \\
\text { understanding of how society works; and } \\
\text { engage them in the examination of the } \\
\text { country's current human development. }\end{array}$ \\
\hline Philosophy & $\begin{array}{l}\text { Introduction to } \\
\text { Philosophy of the } \\
\text { Human Person / } \\
\text { Pambungad sa } \\
\text { Pilosopiya ng Tao }\end{array}$ & $\begin{array}{l}\text { An initiation to the activity and process of } \\
\text { philosophical reflection as a search for a } \\
\text { synoptic vision of life. Topics to be } \\
\text { discussed include the human experiences of } \\
\text { embodiment, being in the world with others } \\
\text { and the environment, freedom, inter- } \\
\text { subjectivity, sociality, and being unto death. } \\
\text { Ipinakikilala ng kursong ito ang gawain at } \\
\text { mga pamamaraan ng pamimilosopiya bilang } \\
\text { isang pangkabuoang pananaw sa buhay. } \\
\text { Pinagmumunihan dito ang ang ang ang ang } \\
\text { pagkasumasakatawang-diwa ng tao, ang } \\
\text { iba't-ibang larangan ng pakikipamuhay sa } \\
\text { mundo at sa kapaligiran ng tao bilang } \\
\text { malaya, nakikipagkapwa at sumasalipunan, } \\
\text { hanggang kamatayan. }\end{array}$ \\
\hline \multirow{3}{*}{$\begin{array}{l}\text { Physical } \\
\text { Education And } \\
\text { Health }\end{array}$} & $\begin{array}{l}\text { Quarter } \\
\text { Exercise } \\
\text { Fitness }\end{array}$ & $\begin{array}{l}\text { This subject on exercise for fitness enables } \\
\text { the learner to set goals, monitor one's } \\
\text { participation in aerobic and muscle- and } \\
\text { bone-strengthening activities, and } \\
\text { constantly evaluate how well one has } \\
\text { integrated this into one's personal lifestyle. } \\
\text { It consists of an array of offerings learners } \\
\text { can choose from. }\end{array}$ \\
\hline & $\begin{array}{l}\text { Quarter 2- } \\
\text { Individual, Dual, } \\
\text { and Team Sports }\end{array}$ & $\begin{array}{l}\text { This subject comprises individual, dual, and } \\
\text { team sports in competitive and recreational } \\
\text { settings. It consists of an array of offerings } \\
\text { learners can choose from. }\end{array}$ \\
\hline & $\begin{array}{l}\text { Quarter 3- } \\
\text { Philippine } \\
\text { Dances }\end{array}$ & $\begin{array}{l}\text { This subject includes rhythmical movement } \\
\text { patterns, the promotion and appreciation of } \\
\text { Philippine folk dance, and indigenous and } \\
\text { traditional dances, as well as other dance }\end{array}$ \\
\hline
\end{tabular}




\begin{tabular}{|l|l|l|}
\hline \multicolumn{2}{|c|}{ THE CORE CURRICULUM } \\
\hline Learning Area & \multicolumn{1}{|c|}{ Subject } & \multicolumn{1}{c|}{ Description } \\
\cline { 2 - 3 } & & $\begin{array}{l}\text { forms. It consists of an array of offerings } \\
\text { learners can choose from. }\end{array}$ \\
\hline $\begin{array}{l}\text { Quarter 4- } \\
\text { Recreational } \\
\text { Activities }\end{array}$ & $\begin{array}{l}\text { This subject is associated with outdoor, } \\
\text { natural, or semi-natural settings; it enables } \\
\text { learners to move safely and competently in } \\
\text { these settings while creating a positive } \\
\text { relationship with natural environments and } \\
\text { promoting their sustainable use. It consists } \\
\text { of an array of offerings learners can choose } \\
\text { from. }\end{array}$ \\
\hline
\end{tabular}

*different for STEM

Table 2.6: SHS Core Curriculum Subjects Time Allotment

\begin{tabular}{|c|c|c|}
\hline $\begin{array}{l}\text { Learning } \\
\text { Area }\end{array}$ & Subject & $\begin{array}{l}\text { Number of Hours } \\
\text { per Semester }\end{array}$ \\
\hline \multirow{4}{*}{ Language } & Oral Communication & 80 \\
\hline & Reading and Writing & 80 \\
\hline & $\begin{array}{l}\text { Komunikasyon at Pananaliksik sa Wika at } \\
\text { Kulturang Filipino }\end{array}$ & 80 \\
\hline & $\begin{array}{l}\text { Pagbasa at Pagsusuri ng Iba't-ibang Teksto } \\
\text { Tungo sa Pananaliksik }\end{array}$ & 80 \\
\hline \multirow{2}{*}{ Humanities } & $\begin{array}{l}\text { 21st-century Literature from the } \\
\text { Philippines and the World }\end{array}$ & 80 \\
\hline & $\begin{array}{l}\text { Contemporary Philippine Arts from the } \\
\text { Regions }\end{array}$ & 80 \\
\hline \multirow{2}{*}{ Mathematics } & General Mathematics & 80 \\
\hline & Statistics and Probability & 80 \\
\hline \multirow[b]{2}{*}{ Science } & Earth and Life Science & 80 \\
\hline & Physical Science & 80 \\
\hline \multirow[b]{2}{*}{ Social Science } & Personal Development & 80 \\
\hline & $\begin{array}{l}\text { Understanding Culture, Politics, and } \\
\text { Society }\end{array}$ & 80 \\
\hline Philosophy & $\begin{array}{l}\text { Introduction to Philosophy of the Human } \\
\text { Person / Pambungad sa Pilosopiya ng Tao }\end{array}$ & 80 \\
\hline \multirow{4}{*}{$\begin{array}{l}\text { Physical } \\
\text { Education and } \\
\text { Health }\end{array}$} & Quarter 1- Exercise for Fitness & 20 \\
\hline & $\begin{array}{l}\text { Quarter 2- Individual, Dual, and Team } \\
\text { Sports }\end{array}$ & 20 \\
\hline & Quarter 3- Philippine Dances & 20 \\
\hline & Quarter 4-Recreational Activities & 20 \\
\hline
\end{tabular}

*different for STEM

\section{B. The SHS Tracks and Strands}

38. On top of the 15 subjects in the core curriculum, the remaining 16 subjects are spread over the 4 SHS tracks: 1) Academic, 2) Arts and Design, 3) Sports, and 4) Technical-Vocational-Livelihood. Students are expected to enroll in the track of their choice. Each track has its own set of Applied Track Subjects and Specialized Subjects. Each subject in the track will have 80 hours in a semester as well, with a total of 1,280 hours for the Applied Track and Specialized Subjects altogether. Regardless of which track the student is enrolled in, $\mathrm{s} /$ he takes up the Applied Track Subjects. These are geared toward the acquisition of common but critical 
competencies in SHS, i.e. English language proficiency, research, ICT, etc., but delivered with teaching-learning content and strategies customized to the requirements of each track.

THE APPLIED TRACK

Table 2.7: Applied Track Subjects Across the 4 SHS Tracks

\begin{tabular}{|c|c|}
\hline \multicolumn{2}{|r|}{ APPLIED TRACK SUBJECTS } \\
\hline Subject & Description \\
\hline $\begin{array}{l}\text { English for Academic } \\
\text { and Professional } \\
\text { Purposes }\end{array}$ & $\begin{array}{l}\text { This subject deals with the development of } \\
\text { communication skills in English for academic and } \\
\text { professional purposes. }\end{array}$ \\
\hline Practical Research 1 & $\begin{array}{l}\text { This subject deals with the development of critical } \\
\text { thinking and problem-solving skills through } \\
\text { qualitative research. }\end{array}$ \\
\hline Practical Research 2 & $\begin{array}{l}\text { This subject deals with the development of critical } \\
\text { thinking and problem-solving skills through } \\
\text { quantitative research. }\end{array}$ \\
\hline $\begin{array}{ll}\text { Filipino } & \text { sa Piling } \\
\text { Larangan } & \text { (Akademik, } \\
\text { Isports, Sining, at } \\
\text { Tech-Voc) }\end{array}$ & $\begin{array}{l}\text { Pagsulat ng iba't-ibang anyo ng sulating lilinang sa } \\
\text { kakayahang magpahayag tungo sa mabisa, mapanuri, } \\
\text { at masinop na pagsusulat sa piniling larangan. }\end{array}$ \\
\hline $\begin{array}{l}\text { Empowerment } \\
\text { Technologies (for the } \\
\text { Strand) }\end{array}$ & $\begin{array}{l}\text { This subject covers information and communication } \\
\text { technologies as a tool for curating, contextualizing, } \\
\text { collaborating, and creating content and experiences } \\
\text { for learning in the professional tracks. }\end{array}$ \\
\hline Entrepreneurship & $\begin{array}{l}\text { This subject deals with the concepts, underlying } \\
\text { principles, processes, and implementation of a } \\
\text { business plan. }\end{array}$ \\
\hline $\begin{array}{l}\text { Inquiries, } \\
\text { Investigations, } \\
\text { Immersion }\end{array}$ & $\begin{array}{l}\text { This subject/course will require the learner to } \\
\text { demonstrate competencies acquired in an integrative, } \\
\text { scientific, or creative manner in his or her chosen area } \\
\text { of specialization }\end{array}$ \\
\hline
\end{tabular}

*different for STEM

39. Besides developing critical competencies for learners, the Applied Track Subjects also make the SHS curriculum flexible because it allows the learner to move across tracks, in case $\mathrm{s} /$ he changes her/his mind in the middle of SHS. The Applied Track Subjects will equip the learners with the same competencies required across tracks. The delivery of the subjects may be adjusted according to the context and content of the tracks. Therefore, the students learn the same skill/competency despite the different teaching-learning content and strategy. For example, the Arts and Design Track research subjects may focus on the study of a particular art technique while the Sports Track research subjects may focus on the mechanics of a particular sport. Although the topics of the research subjects are different, the students will be learning and applying the same research skills.

40. Specialized subjects, as they have been previously mentioned, have content streamlined to each SHS track. 
Table 2.8. Applied Track Subjects with corresponding number of hours*

\begin{tabular}{|l|c|c|}
\hline \multicolumn{1}{|c|}{ Subject } & $\begin{array}{c}\text { Number of Hours per } \\
\text { semester }\end{array}$ & Pre-requisite \\
\hline $\begin{array}{l}\text { English for Academic and } \\
\text { Professional Purposes }\end{array}$ & 80 & \\
\hline Practical Research 1 & 80 & $\begin{array}{c}\text { Statistics and } \\
\text { Probability }\end{array}$ \\
\hline Practical Research 1I & 80 & \\
\hline $\begin{array}{l}\text { Filipino sa Piling Larang } \\
\text { (Akademik, Isports, Sining, } \\
\text { at Tech-Voc) }\end{array}$ & 80 & \\
\hline $\begin{array}{l}\text { Empowerment Technologies } \\
\text { for the Strand) }\end{array}$ & 80 & \\
\hline Entrepreneurship & 80 & \\
\hline $\begin{array}{l}\text { Inquiries, Investigations, } \\
\text { and Immersion }\end{array}$ & 80 & \\
\hline
\end{tabular}

Table 2.9: Medium of Teaching and Learning in Grades 11 to 12

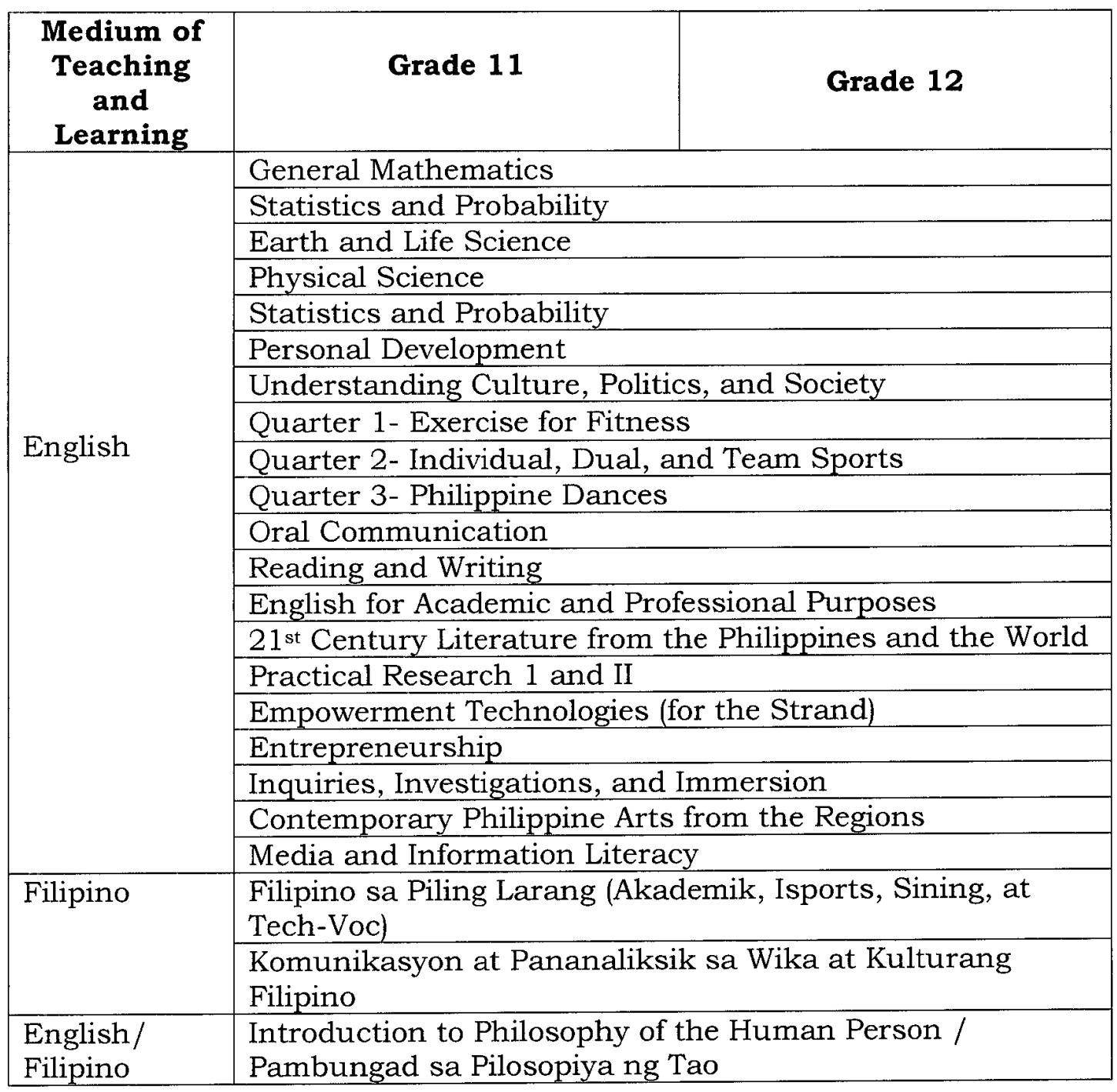




\section{THE ACADEMIC TRACK}

41. The Academic Track has four strands:

a. Accountancy, Business and Management (ABM) Strand

b. Science, Technology, Engineering, and Mathematics (STEM) Strand

c. Humanities and Social Science (HUMSS) Strand and

d. General Academic Strand (GAS)

\section{Academic Track: Accountancy, Business and Management Strand}

42. The ABM Strand is for those who plan to take up business-related courses in higher education or engage in business, entrepreneurship, and other business-related careers. The subjects under this strand are in Table 2.10.

Table 2.10 Specialized Subjects in the Accountancy, Business, and Management (ABM) Strand

\begin{tabular}{|c|c|}
\hline \multicolumn{2}{|r|}{ ACCOUNTANCY, BUSINESS, AND MANAGEMENT } \\
\hline Subject & Description \\
\hline Applied Economics & $\begin{array}{l}\text { This subject is an introduction to the application of economic } \\
\text { principles to management of business organizations. It also } \\
\text { covers familiarization with Philippine industries as an aid to } \\
\text { identifying potential business opportunities. This subject } \\
\text { covers analysis of industries and culminates in the } \\
\text { preparation of a socio-economic impact study of a business } \\
\text { venture. }\end{array}$ \\
\hline $\begin{array}{l}\text { Business Ethics } \\
\text { and Social } \\
\text { Responsibility }\end{array}$ & $\begin{array}{l}\text { This subject deals with the fundamental concepts, principles, } \\
\text { and practices of ethical standards in the business } \\
\text { environment. It combines the theoretical foundations of } \\
\text { setting up business enterprises in the context of personal } \\
\text { accountability and social responsibility. }\end{array}$ \\
\hline $\begin{array}{l}\text { Fundamentals of } \\
\text { Accountancy, } \\
\text { Business, and } \\
\text { Management } 1 \\
\text { (Grade } 11 \text { Quarter } \\
\text { 3) }\end{array}$ & $\begin{array}{l}\text { This is an introduction to accounting, business, and } \\
\text { management data analysis that will develop students' } \\
\text { appreciation of accounting as a language of business and an } \\
\text { understanding of basic accounting concepts and principles } \\
\text { that will help them analyze business transactions. }\end{array}$ \\
\hline $\begin{array}{l}\text { Fundamentals of } \\
\text { Accountancy, } \\
\text { Business, and } \\
\text { Management } 1 \\
\text { (Grade } 11 \text { Quarter } \\
\text { 4) }\end{array}$ & $\begin{array}{l}\text { This subject discusses the accounting cycle for a service } \\
\text { business and a merchandising business of a sole } \\
\text { proprietorship. This includes journalizing of transactions, } \\
\text { posting to the ledger, preparation of a trial balance, } \\
\text { preparation of adjusting entries, worksheet preparation, and } \\
\text { completing the cycle. }\end{array}$ \\
\hline $\begin{array}{l}\text { Fundamentals of } \\
\text { Accountancy, } \\
\text { Business and } \\
\text { Management } 2 \\
\text { (Grade } 12 \text { Quarter } \\
\text { 1) }\end{array}$ & $\begin{array}{l}\text { This subject deals with the preparation and analysis of } \\
\text { financial statements of a service business and merchandising } \\
\text { business using horizontal and vertical analyses and financial } \\
\text { ratios. Knowledge and skills in the analysis of financial } \\
\text { statements will aid the future entrepreneurs in making good } \\
\text { economic decisions. }\end{array}$ \\
\hline $\begin{array}{l}\text { Fundamentals of } \\
\text { Accountancy, } \\
\text { Business, and }\end{array}$ & $\begin{array}{l}\text { This subject deals with the preparation of basic business } \\
\text { forms and documents that includes bank transactions, and } \\
\text { preparation of a simple bank reconciliation statement. }\end{array}$ \\
\hline
\end{tabular}




\begin{tabular}{|c|c|}
\hline \multicolumn{2}{|c|}{ ACCOUNTANCY, BUSINESS, AND MANAGEMENT } \\
\hline Subject & $\begin{array}{l}\text { Description } \\
\end{array}$ \\
\hline $\begin{array}{l}\text { Management } 2 \\
\text { (Grade } 12 \text { Quarter } \\
\text { 2) }\end{array}$ & $\begin{array}{l}\text { Integration of information technology in accounting will also } \\
\text { be introduced. The students will prepare an accounting } \\
\text { practice set that requires the application of learning in the } \\
\text { first three accounting subjects. }\end{array}$ \\
\hline Business Math & $\begin{array}{l}\text { This subject will provide an understanding of the basic } \\
\text { concepts of mathematics as applied in business. It includes a } \\
\text { review of the fundamental mathematics operations using } \\
\text { decimals, fractions, percentages, ratios, and proportions; } \\
\text { mathematics concepts and skills in buying and selling; } \\
\text { computing gross and net earnings; overtime and business } \\
\text { data presentation; and analysis and interpretation. The use } \\
\text { of the computer and software applications for computation } \\
\text { and data presentation is encouraged in this subject. }\end{array}$ \\
\hline Business Finance & $\begin{array}{l}\text { This subject deals with the fundamental principles, tools, and } \\
\text { techniques of the financial operation involved in the } \\
\text { management of business enterprises. It covers the } \\
\text { introduction to money, finance, the Philippine financial } \\
\text { system, financial analysis, financial planning and control, } \\
\text { introduction to investments, and personal finance. Using the } \\
\text { dual learning approach of theory and application, each } \\
\text { chapter and module engages the learner to explore all stages } \\
\text { of the learning process from knowledge, analysis, evaluation, } \\
\text { and application to preparation and development of financial } \\
\text { plans and programs suited for a small business. }\end{array}$ \\
\hline $\begin{array}{l}\text { Organization and } \\
\text { Management }\end{array}$ & $\begin{array}{l}\text { This subject is designed to familiarize students with the basic } \\
\text { concepts, principles, and processes related to business } \\
\text { organization, and the functional areas of management. } \\
\text { Particular emphasis will be given to the study of management } \\
\text { functions like planning, organizing, leading, and controlling, } \\
\text { and to orienting the students on the importance of these } \\
\text { functions and the role of each area in entrepreneurship. }\end{array}$ \\
\hline $\begin{array}{l}\text { Principles of } \\
\text { Marketing }\end{array}$ & $\begin{array}{l}\text { This subject deals with the principles and practices in } \\
\text { marketing goods and services. It also focuses on the } \\
\text { development of integrated marketing programs that will help } \\
\text { grow businesses. }\end{array}$ \\
\hline $\begin{array}{l}\text { Work Immersion/ } \\
\text { Research/Career } \\
\text { Advocacy/ } \\
\text { Culminating } \\
\text { Activity i.e. } \\
\text { Business Enterprise } \\
\text { Simulation }\end{array}$ & $\begin{array}{l}\text { This subject integrates all the key concepts and processes of } \\
\text { Accounting, Business, and Management (ABM) as applied in } \\
\text { real-life activities following the business cycle: business } \\
\text { opportunity research, product/service conception, business } \\
\text { formation/organization, business implementation, business } \\
\text { control, business liquidation, and management reporting in } \\
\text { the context of ethical standard and social responsibility. } \\
\text { Appropriate technologies will be used in a business } \\
\text { enterprise. }\end{array}$ \\
\hline
\end{tabular}

\section{Academic Track: Science, Technology, Engineering and Mathematics}

43. SHS students who are inclined toward, or have the aptitude for, Math, Science and Engineering studies can enroll in the Science, Technology, Engineering and Mathematics (STEM) Strand. This strand covers the following subjects: 
Table 2.11: Specialized Subjects in the Science, Technology, Engineering and Mathematics (STEM) Strand

\begin{tabular}{|c|c|}
\hline \multicolumn{2}{|c|}{ SCIENCE, TECHNOLOGY, ENGINEERING, AND MATHEMATICS } \\
\hline Subject & Description \\
\hline Pre-Calculus & $\begin{array}{l}\text { This subject aims to equip the students with competencies } \\
\text { in solving real-life problems using analytic geometry, } \\
\text { series and mathematical induction, and trigonometry. }\end{array}$ \\
\hline Basic Calculus & $\begin{array}{l}\text { This subject aims to equip the students with the following } \\
\text { competencies: how to compute limit of a function; } \\
\text { differentiate and integrate algebraic, exponential, } \\
\text { logarithmic, and trigonometric functions in one variable; } \\
\text { and to solve real-life problems involving continuity, } \\
\text { extreme values, related rates, population models, and } \\
\text { areas of plane regions. }\end{array}$ \\
\hline General Biology 1 & $\begin{array}{l}\text { This subject is designed to enhance the understanding of } \\
\text { the principles and concepts in the study of Biology, } \\
\text { particularly of life processes at the cellular and molecular } \\
\text { levels. It also covers transformation of energy in } \\
\text { organisms. }\end{array}$ \\
\hline General Biology 2 & $\begin{array}{l}\text { This subject is designed to enhance the understanding of } \\
\text { the principles and concepts in the study of Biology, } \\
\text { particularly of heredity and variation, and the diversity of } \\
\text { living organisms, their structure, function, and evolution. }\end{array}$ \\
\hline General Physics 1 & $\begin{array}{l}\text { This subject covers the study of mechanics of particles, } \\
\text { rigid bodies, and fluids; waves; and heat and } \\
\text { thermodynamics using the methods and concepts of } \\
\text { algebra, geometry, trigonometry, graphical analysis, and } \\
\text { basic calculus. }\end{array}$ \\
\hline General Physics 2 & $\begin{array}{l}\text { This subject covers the study of electricity and magnetism; } \\
\text { optics; the basics of special relativity, atomic, and nuclear } \\
\text { phenomena using the methods and concepts of algebra, } \\
\text { geometry, trigonometry, graphical analysis, and basic } \\
\text { calculus. }\end{array}$ \\
\hline $\begin{array}{l}\text { General Chemistry } 1 \\
\text { and } 2\end{array}$ & $\begin{array}{l}\text { This subject covers the study of composition, structure, } \\
\text { and properties of matter; quantitative principles, kinetics, } \\
\text { and energetics of transformations of matter; and } \\
\text { fundamental concepts of Organic Chemistry. }\end{array}$ \\
\hline $\begin{array}{l}\text { Work Immersion/ } \\
\text { Research/ Career } \\
\text { Advocacy/ } \\
\text { Culminating Activity }\end{array}$ & $\begin{array}{l}\text { In this subject, the students will identify a scientific or } \\
\text { technological problem, design and apply an appropriate } \\
\text { methodology, formulate hypothesis, and draw conclusions } \\
\text { based on their investigation. Toward the end of the } \\
\text { semester, students will prepare a scientific report/paper } \\
\text { to be presented/defended in a forum. }\end{array}$ \\
\hline
\end{tabular}

44. The STEM strand has a unique configuration in relation to two (2) subjects in the Core Curriculum: Physical Science and Earth and Life Science subjects. Physical Science consists of basic topics in Physics and Chemistry, while the Earth and Life Science subject includes basic topics in Biology, which are already covered by the STEM subjects. Therefore, to avoid repetition of content, students in the STEM Strand will instead take the following core curriculum subjects: Earth Science and Disaster Readiness and Risk Reduction. 
Table 2.12: Special Core Curriculum Subjects in the Science, Technology, Engineering, and Mathematics (STEM) Strand

\begin{tabular}{|c|l|}
\hline \multicolumn{2}{|c|}{ SCIENCE, TECHNOLOGY, ENGINEERING, AND MATHEMATICS } \\
\hline Subject & \multicolumn{1}{c|}{ Description } \\
\hline Earth Science & $\begin{array}{l}\text { This learning area is designed to provide a general } \\
\text { background for the understanding of the Earth on a } \\
\text { planetary scale. It presents the history of the Earth } \\
\text { through geologic time. It discusses the Earth's structure } \\
\text { and composition, the processes that occur beneath and on } \\
\text { the Earth's surface, as well as issues, concerns, and } \\
\text { problems pertaining to Earth's resources. }\end{array}$ \\
\hline $\begin{array}{l}\text { Disaster Readiness } \\
\text { and Risk Reduction }\end{array}$ & $\begin{array}{l}\text { knis subject focuses on the application of scientific } \\
\text { knowledge in solving practical problems in the physical } \\
\text { environment. It is designed to bridge the gap between } \\
\text { theoretical science and daily life experience in the context } \\
\text { of man-made and natural disasters. }\end{array}$ \\
\hline
\end{tabular}

\section{Academic Track: Humanities and Social Sciences}

45. Another strand in the academic track is the Humanities and Social Sciences (HUMSS) Strand for learners who want to pursue these fields of study at the university level. It has four Humanities subjects and four Social Science subjects which are listed in Table 2.13

\section{Table 2.13: Specialized Subjects in the Humanities and Social Sciences (HUMSS) Strand}

\begin{tabular}{|c|c|}
\hline \multicolumn{2}{|r|}{ HUMANITIES AND SOCIAL SCIENCES } \\
\hline Subject & Description \\
\hline $\begin{array}{l}\text { Creative } \\
\text { Writing/ } \\
\text { Malikhaing } \\
\text { Pagsulat }\end{array}$ & $\begin{array}{l}\text { The course aims to develop practical and creative skills in reading } \\
\text { and writing; introduce students to the fundamental techniques of } \\
\text { writing fiction, poetry, and drama; and discuss the use of such } \\
\text { techniques by well-known authors in a variety of genres. Each } \\
\text { class will be devoted to the examination of techniques and to the } \\
\text { workshop of students' drafts toward the enrichment of their } \\
\text { manuscripts. Students learn how to combine inspiration and } \\
\text { revision, and to develop a sense of form. } \\
\text { Lilinangin ng kurso ang kasanayang praktikal at malikhain sa } \\
\text { pagbasa at pagsulat; ipauunawa at tatalakayin ang mga } \\
\text { pundamental na teknik sa pagsulat ng maikling kuwento, tula, at } \\
\text { dula na ginamit ng mga kilalang manunulat ng nabanggit na mga } \\
\text { anyo. Tutuon ang klase sa matalas na pagsusuri sa mga teknikat at } \\
\text { worksyap ng mga buradorng mga mag-aaral sa lalo pang ikaiinam } \\
\text { ng kanilang mga manuskrito. Matutuhan ng mga mag-aaral ang } \\
\text { pagsasanib ng inspirasyon at rebisyon at ang malalim na } \\
\text { pagkaunawa sa mga anyo. }\end{array}$ \\
\hline $\begin{array}{l}\text { Creative } \\
\text { Nonfiction }\end{array}$ & $\begin{array}{l}\text { Focusing on formal elements and writing techniques, including } \\
\text { autobiography and blogging, among others, the subject introduces } \\
\text { the students to the reading and writing of Creative Nonfiction as a } \\
\text { literary form. The subject develops in students skills in reading, } \\
\text { and critical and creative thinking that will help them become }\end{array}$ \\
\hline
\end{tabular}




\begin{tabular}{|c|c|}
\hline \multicolumn{2}{|r|}{ HUMANITIES AND SOCIAL SCIENCES } \\
\hline Subject & Description \\
\hline & imaginative readers and writers. \\
\hline $\begin{array}{l}\text { Introduction to } \\
\text { World } \\
\text { Religions and } \\
\text { Belief Systems }\end{array}$ & $\begin{array}{l}\text { The course explores the main tenets and practices of major world } \\
\text { religions: Judaism, Christianity, Islam, Hinduism, Theravada } \\
\text { Buddhism, Mahayana Buddhism, Confucianism, Taoism, and } \\
\text { Shintoism. It aims to help learners understand the historical } \\
\text { contexts of nine religions, appreciate their uniqueness and } \\
\text { similarities, and promote mutual understanding among believers } \\
\text { of different faiths. Learners are expected to demonstrate an } \\
\text { understanding and appreciation of one's faith and that of others. }\end{array}$ \\
\hline $\begin{array}{l}\text { Community } \\
\text { Engagement, } \\
\text { Solidarity, and } \\
\text { Citizenship }\end{array}$ & $\begin{array}{l}\text { This course focuses on the application of ideas and methods of the } \\
\text { social sciences to understand, investigate, and examine challenges } \\
\text { of contemporary community life. It focuses on community-action } \\
\text { initiatives such as community engagement, solidarity, and } \\
\text { citizenship as guided by the core values of human rights, social } \\
\text { justice, empowerment and advocacy, gender equality, and } \\
\text { participatory development. It aims at enhancing students' sense of } \\
\text { shared identity and willingness to contribute to the pursuit of the } \\
\text { common good of the community. It enables students to integrate } \\
\text { applied social sciences into community-action initiatives. }\end{array}$ \\
\hline $\begin{array}{l}\text { Philippine } \\
\text { Politics and } \\
\text { Governance }\end{array}$ & $\begin{array}{l}\text { This course introduces the students to the basic concepts and vital } \\
\text { elements of politics and governance from a historical-institutional } \\
\text { perspective. In particular, it attempts to explain how the important } \\
\text { features of our country's political structures/institutions, } \\
\text { processes, and relationships developed across time. In the } \\
\text { process, the course helps the learners gain a better appreciation } \\
\text { of their rights and responsibilities as individuals and as members } \\
\text { of the larger sociopolitical community to strengthen their civic } \\
\text { competence. }\end{array}$ \\
\hline $\begin{array}{l}\text { Trends, } \\
\text { Networks, and } \\
\text { Critical } \\
\text { Thinking in } \\
\text { the } 21 \text { st } \\
\text { Century }\end{array}$ & $\begin{array}{l}\text { The course provides opportunities for students to discover } \\
\text { patterns and extract meanings from emerging trends. It will } \\
\text { provide opportunities for students to develop their critical, } \\
\text { creative, and compassionate thinking as well as their decision- } \\
\text { making skills. Global trends in the } 21 \text { st century are examined, and } \\
\text { a stance is made on whether to accept or reject these based on } \\
\text { sound criteria. Students will be asked to create and analyze } \\
\text { scenarios that will challenge them to formulate their stance on } \\
\text { issues or concerns, propose interventions, and formulate } \\
\text { alternative futures. The students will realize the interconnections } \\
\text { between their neural connections and social realities. }\end{array}$ \\
\hline $\begin{array}{l}\text { Disciplines } \\
\text { and Ideas in } \\
\text { the Social } \\
\text { Sciences }\end{array}$ & $\begin{array}{l}\text { The course introduces students to basic concepts and subjects } \\
\text { and methods of inquiry in the disciplines that form the Social } \\
\text { Sciences. It then discusses influential thinkers and ideas in these } \\
\text { disciplines. It relates these ideas to the Philippine setting and } \\
\text { current global trends. }\end{array}$ \\
\hline $\begin{array}{l}\text { Disciplines } \\
\text { and Ideas in } \\
\text { the Applied } \\
\text { Social } \\
\text { Sciences }\end{array}$ & $\begin{array}{l}\text { This course introduces some Applied Social Sciences, namely, } \\
\text { Counseling, Social Work, and Communication, which draw their } \\
\text { foundation from the theories and principles of Psychology, } \\
\text { Sociology, Anthropology, and other social sciences. The course } \\
\text { highlights the seamless interconnectivity of the different applied } \\
\text { social science disciplines while focusing on the processes and } \\
\text { applications of these applied disciplines in critical development }\end{array}$ \\
\hline
\end{tabular}




\begin{tabular}{|l|l|}
\hline \multicolumn{1}{|c|}{ HUMANITIES AND SOCIAL SCIENCES } \\
\hline \multicolumn{1}{|c|}{ Subject } & \multicolumn{1}{c|}{ Description } \\
\hline & areas. \\
\hline $\begin{array}{l}\text { HUMSS } \\
\text { Culminating } \\
\text { Activity/Work } \\
\text { Immersion }\end{array}$ & $\begin{array}{l}\text { This course is designed to provide students the opportunity to } \\
\text { integrate their learning in the different learning areas of } \\
\text { humanities and social sciences through a creative culminating } \\
\text { activity. It focuses on the exhibitions/exhibits of authentic } \\
\text { products and performances as evidence of their learning in the } \\
\text { field of humanities and social sciences. }\end{array}$ \\
\hline
\end{tabular}

\section{Academic Track: General Academic Strand}

46. The fourth strand in the Academic Track is the General Academic Strand, which has subjects selected from the different strands. This strand is ideal for SHS students who have not yet decided on a particular specialization. This strand, which is also a viable offering in secondary schools with a low student population, allows for electives that may be a combination of related subjects from the other tracks or strands in the SHS curriculum. The subjects for the General Academic Strand are provided in Table 2.14.

Table 2.14: Specialized Subjects in General Academic Strand

\begin{tabular}{|c|c|}
\hline \multicolumn{2}{|r|}{ GENERAL ACADEMIC STRAND } \\
\hline Subject & $\begin{array}{l}\text { Description } \\
\end{array}$ \\
\hline Humanities 1 & \multirow{3}{*}{$\begin{array}{l}\text { These may be taken from any of the Humanities and Social } \\
\text { Sciences subjects in the Humanities and Social Sciences } \\
\text { Strand. }\end{array}$} \\
\hline Humanities 2 & \\
\hline Social Science 1 & \\
\hline Applied Economics & \multirow{2}{*}{$\begin{array}{l}\text { These are subjects from the Accountancy, Business, and } \\
\text { Management Strand. }\end{array}$} \\
\hline $\begin{array}{l}\text { Organization and } \\
\text { Management }\end{array}$ & \\
\hline $\begin{array}{l}\text { Disaster Readiness and } \\
\text { Risk Reduction }\end{array}$ & $\begin{array}{l}\text { This is a subject from the special core curriculum subjects } \\
\text { for the STEM Strand. }\end{array}$ \\
\hline 1. Elective 1 & \multirow{2}{*}{ These may be taken from any of the Tracks or Strands. } \\
\hline 2. Elective 2 & \\
\hline $\begin{array}{l}\text { 3. Work Immersion/ } \\
\text { Research/ Career } \\
\text { Advocacy/ } \\
\text { Culminating Activity }\end{array}$ & $\begin{array}{l}\text { This subject may be a combination of the four options } \\
\text { provided, especially when there is a shortage of work } \\
\text { immersion options. }\end{array}$ \\
\hline
\end{tabular}

\section{THE SPORTS TRACK}

47. The Sports Track is for students who are interested in sports-related careers, i.e. athlete development, fitness training, coaching, etc. Table 2.15 shows the subjects in this track.

Table 2.15: Specialized Subjects in Sports Track

\begin{tabular}{|c|l|}
\hline \multicolumn{2}{|c|}{ SPORTS TRACK } \\
\hline Subject & \multicolumn{1}{c|}{ Description } \\
\hline Safety and First Aid & $\begin{array}{l}\text { This subject aims to equip learners with life skills and } \\
\text { competencies in safety, injury prevention, and management } \\
\text { in various sports and exercise settings. This also covers }\end{array}$ \\
\hline
\end{tabular}




\begin{tabular}{|c|c|}
\hline \multicolumn{2}{|r|}{ SPORTS TRACK } \\
\hline Subject & $\begin{array}{l}\text { Description } \\
\end{array}$ \\
\hline & $\begin{array}{l}\text { appropriate health and safety response during emergencies. } \\
\text { Course completion may lead to a certification from the } \\
\text { Philippine Red Cross. }\end{array}$ \\
\hline Human Movement & $\begin{array}{l}\text { This subject covers topics on the origin, control, and learning } \\
\text { of motor skills appropriate for varied needs and skill levels. }\end{array}$ \\
\hline $\begin{array}{l}\text { Fundamentals of } \\
\text { Coaching }\end{array}$ & $\begin{array}{l}\text { This subject covers the basic concepts and principles of } \\
\text { coaching. }\end{array}$ \\
\hline $\begin{array}{l}\text { Sports Officiating } \\
\text { and Activity } \\
\text { Management }\end{array}$ & $\begin{array}{l}\text { This subject covers the concepts, principles, and mechanics } \\
\text { of officiating, and rules of specific sports. It also covers the } \\
\text { management of fitness, and sports and recreation events. At } \\
\text { the end of the course, the learner will be certified by the } \\
\text { National Sports Associations (NSAs) and TESDA. }\end{array}$ \\
\hline $\begin{array}{l}\text { Fitness, Sports, and } \\
\text { Recreation } \\
\text { Leadership }\end{array}$ & $\begin{array}{l}\text { This subject aims to equip learners with competencies for } \\
\text { managing safe and effective programs in exercise, sports, and } \\
\text { recreation. }\end{array}$ \\
\hline $\begin{array}{l}\text { Psychosocial } \\
\text { Aspects of Sports } \\
\text { and Exercise }\end{array}$ & $\begin{array}{l}\text { This subject will lead to an understanding of individual and } \\
\text { social factors that influence participation, performance, } \\
\text { adherence, and psychological well-being in sports and } \\
\text { exercise. }\end{array}$ \\
\hline $\begin{array}{l}\text { Fitness Testing and } \\
\text { Exercise } \\
\text { Programming }\end{array}$ & $\begin{array}{l}\text { This subject will enable learners to administer tests and } \\
\text { programs for physical fitness and performance enhancement. }\end{array}$ \\
\hline $\begin{array}{l}\text { Practicum } \\
\text { (in-campus) }\end{array}$ & $\begin{array}{l}\text { This subject aims to provide learners with hands-on } \\
\text { experience within the school setting in their area of } \\
\text { specialization such as student athlete enhancement, practice } \\
\text { coaching, practice officiating, and tournament management } \\
\text { or fitness/sports and recreation leadership. }\end{array}$ \\
\hline $\begin{array}{l}\text { Apprenticeship (off- } \\
\text { campus) }\end{array}$ & $\begin{array}{l}\text { This subject aims to provide learners with hands-on off- } \\
\text { campus experience in their area of specialization such as } \\
\text { student athlete enhancement, practice coaching, practice } \\
\text { officiating, and tournament management or fitness/sports } \\
\text { and recreation leadership. This course will allow learners to } \\
\text { explore opportunities for advanced certification. }\end{array}$ \\
\hline
\end{tabular}

\section{THE ARTS AND DESIGN TRACK}

48. The Arts and Design Track covers a wide range of art forms: Theater, Music, Dance, Creative Writing, Visual Arts, and Media Arts. Prior to enrollment, there is art/creative talent assessment and guidance to gauge a student's art inclination and aptitude. The track has six general or common subjects that focus on acquiring competencies required for further specialization in the different artistic areas.

\section{Table 2.16: Specialized Subjects in the Arts and Design Track}

\begin{tabular}{|l|l|}
\hline \multicolumn{1}{|c|}{ ARTS AND DESIGN TRACK } \\
\hline \multicolumn{1}{|c|}{ Subject } & \multicolumn{1}{|c|}{ Description } \\
\hline Creative Industries I: & $\begin{array}{l}\text { This subject presents a survey of the various arts and } \\
\text { Arts and Design }\end{array}$ \\
design production for senior secondary students. It \\
Appreciation and & intends to provide students with knowledge of different \\
Production & arts and design forms, materials, media, and production \\
\hline
\end{tabular}




\begin{tabular}{|l|l|}
\hline \multicolumn{1}{|c|}{ Subject } & \multicolumn{1}{|c|}{ Description } \\
\hline & $\begin{array}{l}\text { in the creative industries. It will also introduce influential } \\
\text { works by significant artists across time and place. }\end{array}$ \\
\hline $\begin{array}{l}\text { Creative Industries } \\
\text { II: Performing Arts } \\
\text { theater, music, and dance, and examines the practical } \\
\text { application of the performing arts skills in the local and } \\
\text { global markets. }\end{array}$ \\
\hline $\begin{array}{l}\text { Physical and } \\
\text { Personal } \\
\text { Arts }\end{array}$ & $\begin{array}{l}\text { This subject aims to provide students with a } \\
\text { comprehensive discussion and practical studies on the } \\
\text { proper care of their bodies as the instrument for their art } \\
\text { through proper exercises, good hygiene, and appropriate } \\
\text { industry practices. }\end{array}$ \\
\hline $\begin{array}{l}\text { Developing Filipino } \\
\text { Identity in the Arts }\end{array}$ & $\begin{array}{l}\text { This subject aims to deepen the learners' awareness of art } \\
\text { in their community and the rest of the nation, and allows } \\
\text { them to explore ways in which they can contribute to the } \\
\text { creation of a national identity using their knowledge and } \\
\text { skills as artists. }\end{array}$ \\
\hline $\begin{array}{l}\text { Integrating the } \\
\text { Elements and } \\
\text { Principles of } \\
\text { Organization in the } \\
\text { Arts }\end{array}$ & $\begin{array}{l}\text { This subject aims to deepen the learners' understanding } \\
\text { of the elements and principles of organization in the arts } \\
\text { in various forms of creative expressions through a series } \\
\text { of application, creative works, and artistic endeavors for } \\
\text { personal development, advancement of cultural identity, } \\
\text { and communication. }\end{array}$ \\
\hline $\begin{array}{l}\text { Leadership and } \\
\text { Management in } \\
\text { Different Arts Fields }\end{array}$ & $\begin{array}{l}\text { This subject covers the basic concepts, elements, and } \\
\text { processes in arts management, and develops learners' } \\
\text { leadership potential in the arts. }\end{array}$ \\
\hline
\end{tabular}

49. After taking the six (6) general subjects discussed above, a student then chooses an arts field specialization and takes up the following subjects on apprenticeship, art exhibition/performance, or production.

\section{Table 2.17: Specialization Subjects across Different Fields of Study in the Arts and Design Track}

\begin{tabular}{|l|l|l|}
\hline \multicolumn{2}{|c|}{ ARTS AND DESIGN TRACK } \\
\hline \multicolumn{2}{|c|}{ Subject } & $\begin{array}{l}\text { The subject offers an intensive period of } \\
\text { acquiring, understanding, and developing } \\
\text { proficiency in visual arts and design } \\
\text { production through mentoring in art } \\
\text { organization, art center, or production house, } \\
\text { independent artist/designer community- } \\
\text { based art/cultural group. It intends to enrich } \\
\text { the learners' knowledge and skills in their } \\
\text { chosen field, emphasizing artistic, educational, } \\
\text { and cultural values and work ethics. }\end{array}$ \\
$\begin{array}{l}\text { Apprenticeship } \\
\text { and Exploration } \\
\text { of Different Arts } \\
\text { Fields }\end{array}$ & $\begin{array}{l}\text { And Visual } \\
\text { Arts }\end{array}$ & $\begin{array}{l}\text { The subject offers an acquisition of skills for } \\
\text { creative writing and writing for mass media. It } \\
\text { seeks to expose learners to the various types of } \\
\text { writing and literary genres. }\end{array}$ \\
\cline { 2 - 4 } & Literary Arts \\
\cline { 2 - 4 } & Dance & This subject immerses learners in their chosen \\
\hline
\end{tabular}




\begin{tabular}{|c|c|c|}
\hline \multicolumn{3}{|c|}{ ARTS AND DESIGN TRACK } \\
\hline \multicolumn{2}{|c|}{ Subject } & $\begin{array}{l}\text { Description } \\
\end{array}$ \\
\hline & & $\begin{array}{l}\text { strand, specifically the dance strand, gives } \\
\text { them practical and hands-on experience with } \\
\text { choreography, working with a local artist, } \\
\text { performing arts group, or arts organization, } \\
\text { and culminates in a dance production. }\end{array}$ \\
\hline & Music & $\begin{array}{l}\text { The subject offers the exploratory study of local } \\
\text { music genres and ICT applications in music } \\
\text { while deepening the musical skills and } \\
\text { understanding of learners, who are also given } \\
\text { the opportunity to learn various methods of } \\
\text { producing music. }\end{array}$ \\
\hline & Theater & $\begin{array}{l}\text { In this subject, learners will be guided through } \\
\text { a dynamic professional development and given } \\
\text { hands-on opportunities by either placing them } \\
\text { with practicing artists or organizations with } \\
\text { resident artists who can administer on-the-job } \\
\text { mentoring and training; learners may also put } \\
\text { up their own show under the guidance of a } \\
\text { director or an experienced theater practitioner. }\end{array}$ \\
\hline \multirow{3}{*}{$\begin{array}{l}\text { Work } \\
\text { Immersion/ } \\
\text { Research/ } \\
\text { Career } \\
\text { Advocacy/ } \\
\text { Culminating } \\
\text { Activity } \\
\quad \text { i.e. Exhibit for } \\
\text { Arts } \\
\text { Production/ } \\
\text { Performing } \\
\text { Arts } \\
\text { Production }\end{array}$} & $\begin{array}{l}\text { Exhibit for } \\
\text { Arts } \\
\text { Production } \\
\text { (Literary } \\
\text { Arts) }\end{array}$ & $\begin{array}{l}\text { This subject is a culmination activity to } \\
\text { showcase the acquired skills in creative writing } \\
\text { through scriptwriting for a stage production. }\end{array}$ \\
\hline & $\begin{array}{l}\text { Exhibit for } \\
\text { Arts } \\
\text { Production } \\
\text { (Media Arts } \\
\text { and Visual } \\
\text { Arts) }\end{array}$ & $\begin{array}{l}\text { As a final culminating project, the subject } \\
\text { prepares learners to exhibit creative outputs to } \\
\text { showcase their learnings during their } \\
\text { apprenticeship period, with emphasis on } \\
\text { artistic, educational, cultural values, and work } \\
\text { ethics. }\end{array}$ \\
\hline & $\begin{array}{l}\text { Performing } \\
\text { Arts } \\
\text { Production }\end{array}$ & $\begin{array}{l}\text { This subject is a showcase of performing arts } \\
\text { skills enhanced and developed through a } \\
\text { program of apprenticeship. }\end{array}$ \\
\hline
\end{tabular}

50. The apprenticeship subject in the Arts and Design Track will be allocated 160 hours to maximize exposure to the chosen arts field. Meanwhile, the culminating activity serves as a way to showcase/exhibit the acquired/enhanced artistic skills. It can either be an exhibit for arts production or a performing arts production, depending on the student's specialization.

\section{THE TECHNICAL-VOCATIONAL-LIVELIHOOD (TVL) TRACK}

51. The SHS program has a Technical-Vocational-Livelihood (TVL) Track, which has four strands: Agri-Fishery Arts, Home Economics (HE), Information and Communication Technology (ICT), and Industrial Arts. These are aligned with Technology and Livelihood Education (TLE) in Grades 7-10. Each TVL strand offers various specializations that may or may not have a National Certificate (NC) equivalent from TESDA. The time allocation per strand specialization is based on TESDA Training Regulations-Based Courses and is only indicative since the standard time allotment of 80 hours per semester per subject will still be applied. Therefore, 
each strand specialization must be designed to fit into the 80-hour blocks of time.

52. Technology Livelihood Education and Technical-Vocational Livelihood Track Subjects may be taken between Grades 9-12. Schools may offer specializations from the four strands as long as the minimum number of hours for each specialization is met. Curriculum Maps may then be modified according to specializations offered by a school. Below is a list of all the Technology and Livelihood Education and the Technical-Vocational Livelihood Track Specializations, their prescribed number of hours, and their prerequisites and sample curriculum maps:

\section{TVL Track: Agricultural-Fishery Arts (AFA) Strand}

53. This TVL component consists of specializations equivalent to qualifications under agriculture and fishery sectors. Students with agri-fishery arts specializations will be able to demonstrate necessary skills/competencies and values on the cultivation of plants and animal production to harvest food and other products using available technologies on farming and on raising, harvesting, and capturing fish and other aquatic resources. Schools that offer these specializations must have adequate facilities for students' laboratory classes.

Table 2.18: Specialized Subjects for TVL: Agricultural and Fisheries Arts (AFA) Strand

\begin{tabular}{|c|c|c|c|}
\hline & Specialization & $\begin{array}{l}\text { Number } \\
\text { of } \\
\text { Hours }\end{array}$ & Pre-requisite \\
\hline 1 & Agricultural Crops Production (NC I) & 320 & \\
\hline 2 & $\begin{array}{l}\text { Agricultural Crops Production (NC II) } \\
\text { updated based on TESDA Training } \\
\text { Regulations published } 28 \text { December } 2013\end{array}$ & 640 & \\
\hline 3 & Agricultural Crops Production (NC III) & 640 & $\begin{array}{l}\text { Agricultural Crops } \\
\text { Production (NC II) }\end{array}$ \\
\hline 4 & Animal Health Care Management (NC III) & 320 & $\begin{array}{l}\text { Animal Production } \\
\text { (Poultry-Chicken) (NC II) } \\
\text { or } \\
\text { Animal Production } \\
\text { (Ruminants) (NC II) or } \\
\text { Animal Production } \\
\text { (Swine) (NC II) }\end{array}$ \\
\hline 5 & $\begin{array}{l}\text { Animal Production (Poultry-Chicken) (NC } \\
\text { II) } \\
\text { updated based on TESDA Training } \\
\text { Regulations published } 28 \text { December } 2013\end{array}$ & 320 & \\
\hline 6 & $\begin{array}{l}\text { Animal Production (Large Ruminants) (NC } \\
\text { II) } \\
\text { updated based on TESDA Training } \\
\text { Regulations published } 28 \text { December } 2013\end{array}$ & 320 & \\
\hline 7 & $\begin{array}{l}\text { Animal Production (Swine) (NC II) } \\
\text { updated based on TESDA Training } \\
\text { Regulations published } 28 \text { December } 2013\end{array}$ & 320 & \\
\hline 8 & Aquaculture (NC II) & 640 & \\
\hline 9 & $\begin{array}{l}\text { Artificial Insemination (Large Ruminants) } \\
\text { (NC II) }\end{array}$ & 160 & $\begin{array}{l}\text { Animal Production } \\
\text { (Large Ruminants) (NC }\end{array}$ \\
\hline
\end{tabular}




\begin{tabular}{|l|l|l|l|}
\hline & Specialization & $\begin{array}{l}\text { Number } \\
\text { of } \\
\text { Hours }\end{array}$ & Pre-requisite \\
\hline & & 160 & $\begin{array}{l}\text { Animal Production } \\
\text { (Swine) (NC II) }\end{array}$ \\
\hline 10 & Artificial Insemination (Swine) (NC II) & 640 & \\
\hline 11 & Fish Capture (NC II) & 320 & \\
\hline 12 & $\begin{array}{l}\text { Fishing Gear Repair and Maintenance (NC } \\
\text { III) }\end{array}$ & 320 & \\
\hline 13 & Fish-Products Packaging (NC II) & 160 & \\
\hline 14 & Fish Wharf Operation (NC I) & 640 & \\
\hline 15 & Food Processing (NC II) & 640 & $\begin{array}{l}\text { Agricultural Crops } \\
\text { Production (NC II) }\end{array}$ \\
\hline 16 & Horticulture (NC III) & 320 & \\
\hline 17 & $\begin{array}{l}\text { Landscape Installation and Maintenance } \\
\text { (NC II) }\end{array}$ & 320 & \\
\hline 18 & Organic Agriculture (NC II) & 320 & \\
\hline 19 & Pest Management (NC II) & 320 & \\
\hline 20 & Rice Machinery Operations (NC II) & 320 & \\
\hline 21 & Rubber Processing (NC II) & 320 & \\
\hline 22 & Rubber Production (NC II) & 160 & \\
\hline 23 & $\begin{array}{l}\text { Slaughtering Operations (Hog/Swine/Pig) } \\
\text { (NC II) }\end{array}$ & & \\
\hline
\end{tabular}




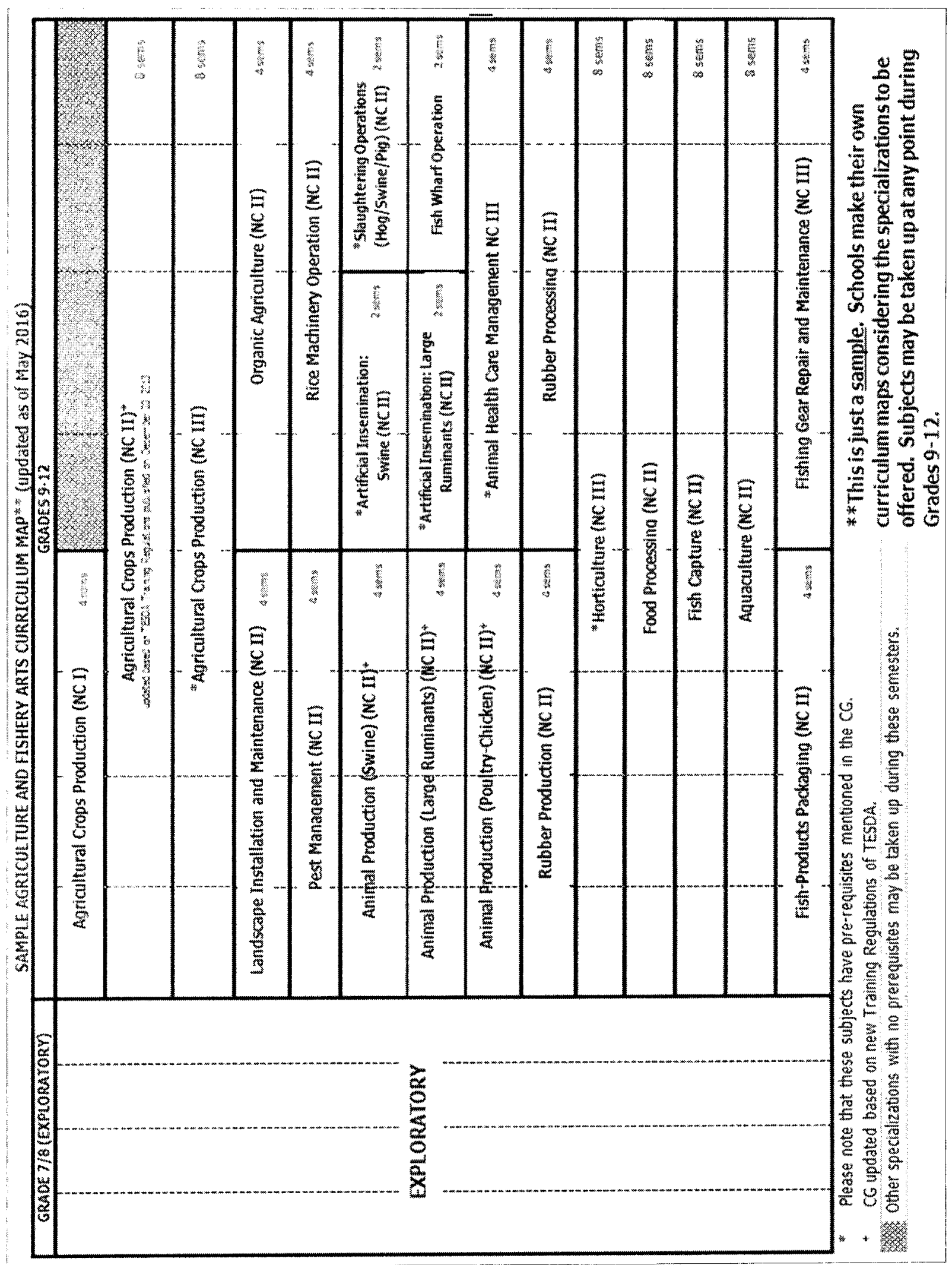

Figure 2.1: Sample Curriculum Map for TVL Track: Agriculture and Fishery Arts (AFA) Strand 


\section{TVL Track: Home Economics (HE) Strand}

54. This TVL component consists of specializations equivalent to qualifications under garments, tourism, health, processed food and beverages, and social and other community development service sectors. Students with home economics specializations will be able to demonstrate the necessary skills, competencies, and values in taking care of oneself and one's family, and in providing efficient services to others and to the community.

Table 2.19: Specialized Subjects for TVL Track: Home Economics (HE) Strand

\begin{tabular}{|c|l|l|l|}
\hline & \multicolumn{1}{|c|}{ Specialization } & $\begin{array}{l}\text { Number of } \\
\text { Hours }\end{array}$ & Pre-requisite \\
\hline 1 & $\begin{array}{l}\text { Attractions and Theme Parks } \\
\text { Operations with Ecotourism (NC II) }\end{array}$ & 160 & \\
\hline 2 & Barbering (NC II) & 320 & \\
\hline 3 & Bartending (NC II) & 320 & \\
\hline 4 & Beauty/Nail Care (NC II) & 160 & \\
\hline 5 & Bread and Pastry Production (NC II) & 160 & \\
\hline 6 & Caregiving (NC II) & 640 & Cookery (NC II) \\
\hline 7 & Commercial Cooking (NC III) & 320 & \\
\hline 8 & Cookery (NC II) & 320 & \\
\hline 9 & Dressmaking (NC II) & 320 & Dressmaking (NC II) or \\
\hline 10 & Events Management Services (NC III) & 320 & Tailoring (NC II) \\
\hline 11 & Fashion Design (Apparel) (NC III) & 640 & \\
\hline & $\begin{array}{l}\text { Food and Beverage Services (NC II) } \\
\text { updated based on TESDA Training } \\
\text { Regulations published 28 December } \\
\text { 2013 }\end{array}$ & 160 & \\
\hline 13 & Front Office Services (NC II) & 160 & \\
\hline 14 & Hairdressing (NC II) & 320 & \\
\hline 15 & Hairdressing (NC III) & 640 & Hairdressing (NC II) \\
\hline 16 & $\begin{array}{l}\text { Handicraft (Basketry, Macrame) } \\
\text { (Non-NC) }\end{array}$ & 160 & \\
\hline 17 & $\begin{array}{l}\text { Handicraft (Fashion Accessories, } \\
\text { Paper Craft) (Non-NC) }\end{array}$ & 160 & \\
\hline 18 & Handicraft (Needlecraft) (Non-NC) & 160 & \\
\hline 19 & $\begin{array}{l}\text { Handicraft (Woodcraft, Leathercraft) } \\
\text { (Non-NC) }\end{array}$ & 160 & \\
\hline & $\begin{array}{l}\text { Housekeeping (NC II) } \\
\text { updated based on TESDA Training } \\
\text { Regulations published 28 December } \\
2013\end{array}$ & 160 & \\
\hline 21 & Local Guiding Services (NC II) & 160 & \\
\hline 22 & Tailoring (NC II) & 320 & \\
\hline 23 & Tourism Promotion Services (NC II) & 160 & \\
\hline 24 & Travel Services (NC II) & 160 & \\
\hline 25 & Wellness Massage (NC II) & 160 & \\
\hline
\end{tabular}




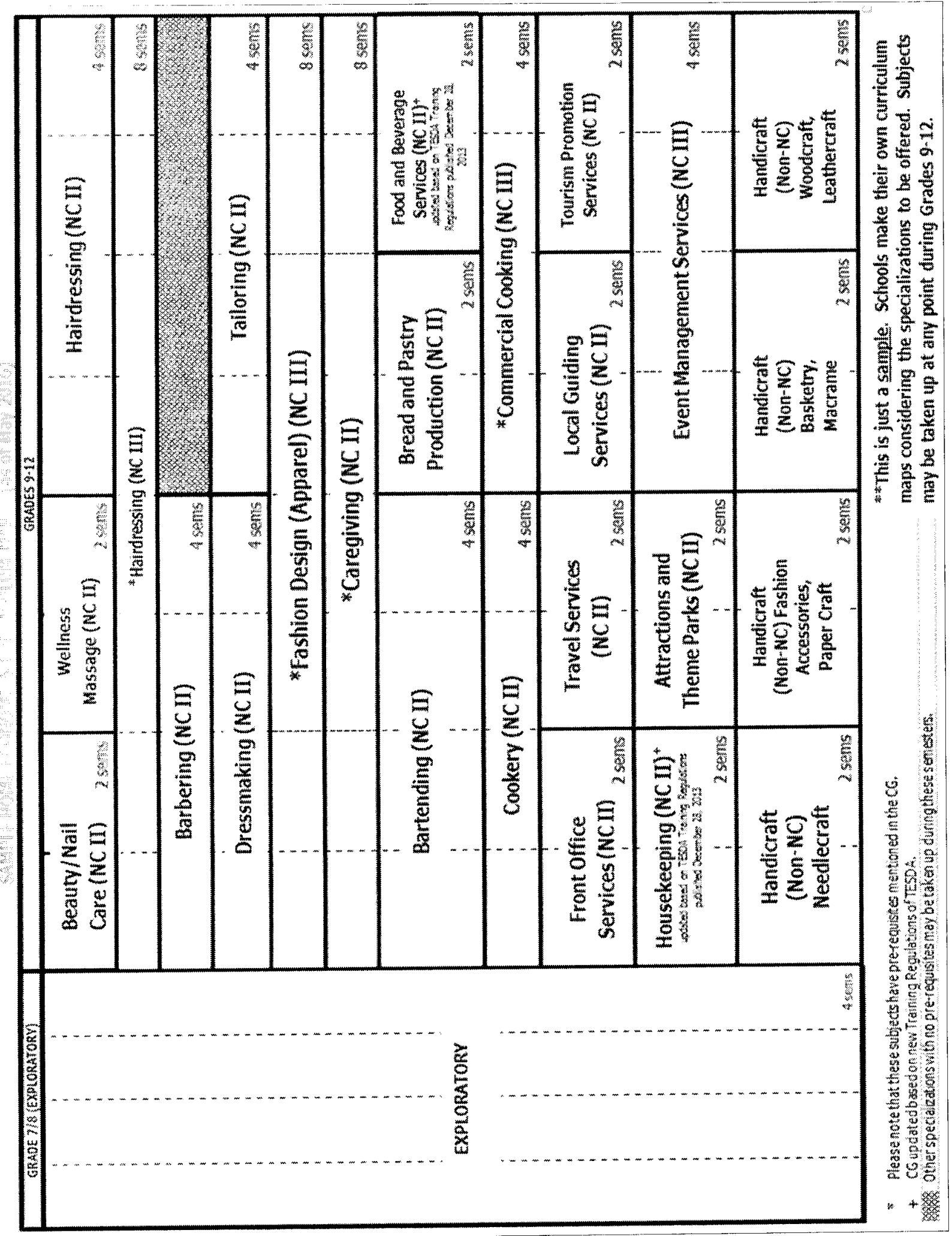

Figure 2.2: Sample Curriculum Map for TVL Track: Home Economics (HE) Strand 


\section{TVL Track: Industrial Arts (IA) Strand}

55. This TVL component consists of specializations equivalent to qualifications under automotive and land transport, construction, electronics, furniture and fixture, metal and engineering, and utilities sectors. Students with industrial arts specializations will be able to demonstrate the skills, competencies, and values in providing repair and maintenance services, installation, manual craftsmanship, and machine safety using available industrial and engineering technologies.

Table 2.20: Specialized Subjects for TVL Track: Industrial Arts (IA) Strand

\begin{tabular}{|c|c|c|c|}
\hline & Specialization & $\begin{array}{c}\text { Number of } \\
\text { Hours }\end{array}$ & Prerequisite \\
\hline 1 & $\begin{array}{l}\text { Automotive Servicing (NC I) } \\
\text { updated based on TESDA Training } \\
\text { Regulations published } 28 \text { December } \\
2013\end{array}$ & 640 & \\
\hline 2 & Automotive Servicing (NC II) & 640 & $\begin{array}{l}\text { Automotive Servicing (NC } \\
\text { I) }\end{array}$ \\
\hline 3 & Carpentry (NC II) & 640 & \\
\hline 4 & Carpentry (NC III) & 320 & Carpentry (NC II) \\
\hline 5 & Construction Painting (NC II) & 160 & \\
\hline 6 & $\begin{array}{l}\text { Domestic Refrigeration and Air- } \\
\text { conditioning (DOMRAC) Servicing } \\
\text { (NC II) }\end{array}$ & 640 & \\
\hline 7 & Driving (NC II) & 160 & \\
\hline 8 & $\begin{array}{l}\text { Electrical Installation and } \\
\text { Maintenance (NC II) }\end{array}$ & 640 & \\
\hline 9 & $\begin{array}{l}\text { Electric Power Distribution Line } \\
\text { Construction (NC II) }\end{array}$ & 320 & $\begin{array}{l}\text { Electrical Installation and } \\
\text { Maintenance (NC II) }\end{array}$ \\
\hline 10 & $\begin{array}{l}\text { Electronic Products Assembly and } \\
\text { Servicing (NC II) } \\
\text { updated based on TESDA Training } \\
\text { Regulations published } 28 \text { December } \\
2013\end{array}$ & 640 & \\
\hline 11 & Furniture Making (Finishing) (NC II) & 640 & \\
\hline 12 & $\begin{array}{l}\text { Instrumentation and Control } \\
\text { Servicing (NC II) }\end{array}$ & 320 & $\begin{array}{l}\text { Electronic Products } \\
\text { Assembly and Servicing } \\
\text { (EPAS) (NC II) }\end{array}$ \\
\hline 13 & $\begin{array}{l}\text { Gas Metal Arc Welding (GMAW) (NC } \\
\text { II) }\end{array}$ & 320 & $\begin{array}{l}\text { Shielded Metal Arc } \\
\text { Welding (SMAW) (NC II) }\end{array}$ \\
\hline 14 & $\begin{array}{l}\text { Gas Tungsten Arc Welding (GTAW) } \\
\text { (NC II) }\end{array}$ & 320 & $\begin{array}{l}\text { Shielded Metal Arc } \\
\text { Welding (GMAW) (NC II) }\end{array}$ \\
\hline 15 & Machining (NC I) & 640 & \\
\hline 16 & Machining (NC II) & 640 & Machining (NC I) \\
\hline 17 & Masonry (NC II) & 320 & \\
\hline 18 & Mechatronics Servicing (NC II) & 320 & $\begin{array}{l}\text { Electronic Products } \\
\text { Assembly and Servicing } \\
\text { (EPAS) (NC II) }\end{array}$ \\
\hline 19 & $\begin{array}{l}\text { Motorcycle/Small Engine Servicing } \\
\text { (NC II) }\end{array}$ & 320 & \\
\hline 20 & Plumbing (NC I) & 320 & \\
\hline
\end{tabular}




\begin{tabular}{|c|c|c|c|}
\hline & Specialization & $\begin{array}{l}\text { Number of } \\
\text { Hours }\end{array}$ & Prerequisite \\
\hline 21 & Plumbing (NC II) & 320 & Plumbing (NC I) \\
\hline 22 & $\begin{array}{l}\text { Refrigeration and Air-Conditioning } \\
\text { (Packaged Air-Conditioning Unit } \\
\text { [PACU]/Commercial Refrigeration } \\
\text { Equipment [CRE]) Servicing (NC III) }\end{array}$ & 640 & $\begin{array}{l}\text { Domestic Refrigeration } \\
\text { and Air-conditioning } \\
\text { (DOMRAC) Servicing (NC } \\
\text { II) }\end{array}$ \\
\hline 23 & Shielded Metal Arc Welding (NC I) & 320 & \\
\hline 24 & Shielded Metal Arc Welding (NC II) & 320 & $\begin{array}{l}\text { Shielded Metal Arc } \\
\text { Welding (NC I) }\end{array}$ \\
\hline 25 & Tile Setting (NC II) & 320 & \\
\hline 26 & $\begin{array}{l}\text { Transmission Line Installation and } \\
\text { Maintenance (NC II) }\end{array}$ & 640 & $\begin{array}{l}\text { Electrical Installation and } \\
\text { Maintenance (NC II) }\end{array}$ \\
\hline
\end{tabular}




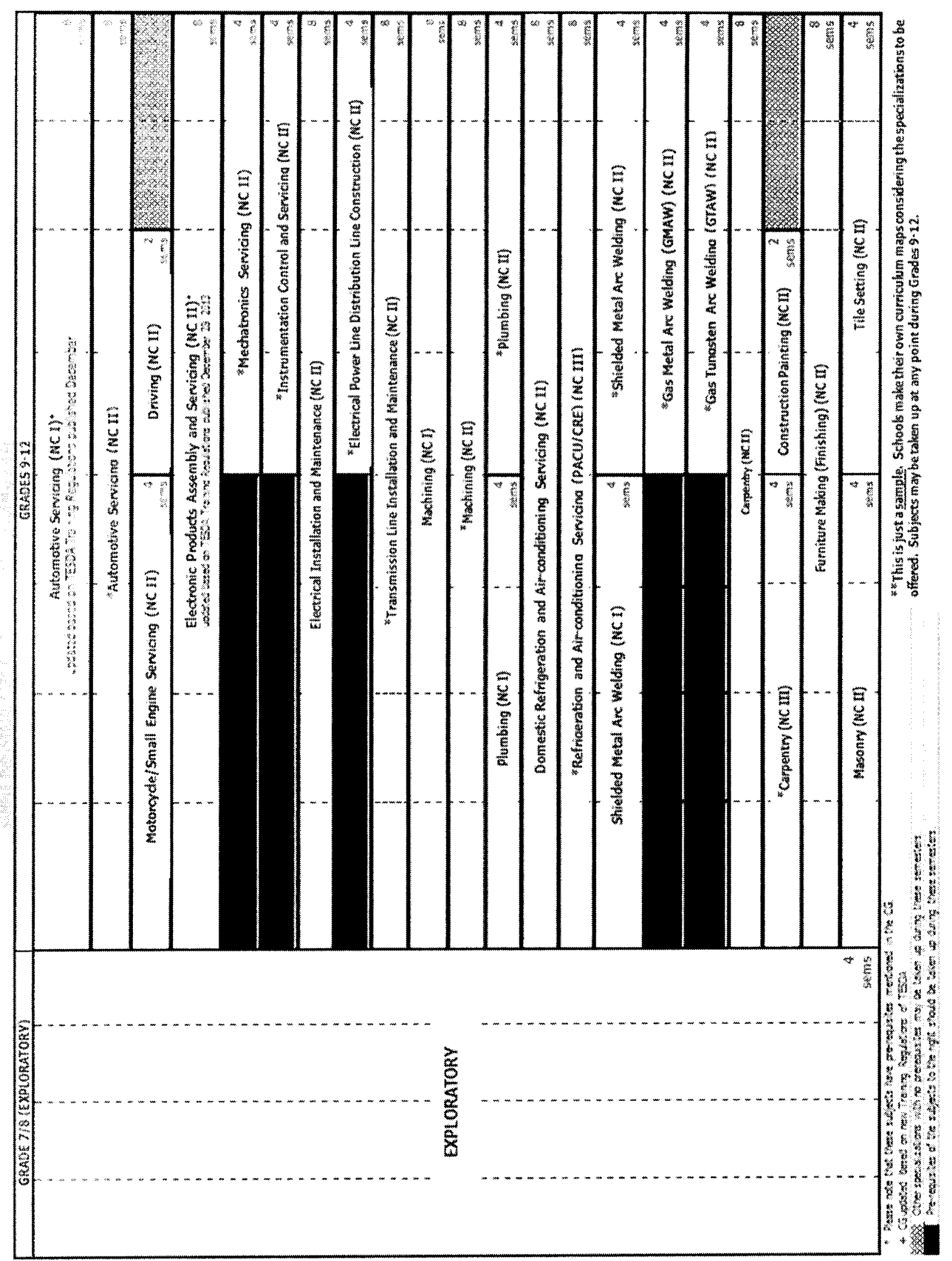

Figure 2.3: Sample Curriculum Map for TVL Track: Industrial Arts (IA) Strand 


\section{TVL Track: Information and Communications Technology (ICT) Strand}

56. This TVL component consists of specializations equivalent to qualifications under the information and communication technologies sector. Students with ICT specializations will be able to demonstrate the skills, competencies, and values in effective application, use, and management of technology in the context of system designing and customer service.

Table 2.21. Specialized Subjects for TVL Track: Information and Communications Technology (ICT) Strand

\begin{tabular}{|c|c|c|c|}
\hline & Specialization & $\begin{array}{c}\text { Number of } \\
\text { Hours }\end{array}$ & Pre-requisite \\
\hline 1. & Animation (NC II) & 320 & \\
\hline 2. & $\begin{array}{l}\text { Broadband Installation (Fixed Wireless } \\
\text { Systems) (NC II) }\end{array}$ & 160 & $\begin{array}{l}\text { Computer Systems } \\
\text { Servicing (NC II) }\end{array}$ \\
\hline 3. & $\begin{array}{l}\text { Computer Programming (.Net } \\
\text { Technology) (NC III) } \\
\text { updated based on TESDA Training } \\
\text { Regulations published December } 28 \\
2013\end{array}$ & 320 & \\
\hline 4. & $\begin{array}{l}\text { Computer Programming (Java) (NC III) } \\
\text { updated based on TESDA Training } \\
\text { Regulations published } 28 \text { December } \\
2013\end{array}$ & 320 & \\
\hline 5. & $\begin{array}{l}\text { Computer Programming (Oracle } \\
\text { Database) (NC III) } \\
\text { updated based on TESDA Training } \\
\text { Regulations published } 28 \text { December } \\
2013\end{array}$ & 320 & \\
\hline 6. & $\begin{array}{l}\text { Computer Systems Servicing (NC II) } \\
\text { updated based on TESDA Training } \\
\text { Regulations published } 28 \text { December } \\
2007\end{array}$ & 640 & \\
\hline 7. & Contact Center Services (NC II) & 320 & \\
\hline 8. & Illustration (NC II) & 320 & \\
\hline 9. & Medical Transcription (NC II) & 320 & \\
\hline 10. & Technical Drafting (NC II) & 320 & \\
\hline 11. & $\begin{array}{l}\text { Telecom OSP and Subscriber Line } \\
\text { Installation } \\
\text { (Copper Cable/POTS and DSL) (NC II) }\end{array}$ & 320 & $\begin{array}{l}\text { Computer Systems } \\
\text { Servicing (NC II) }\end{array}$ \\
\hline 12 . & $\begin{array}{l}\text { Telecom OSP Installation (Fiber Optic } \\
\text { Cable) (NC II) }\end{array}$ & 160 & $\begin{array}{l}\text { Computer Systems } \\
\text { Servicing (NC II) }\end{array}$ \\
\hline
\end{tabular}




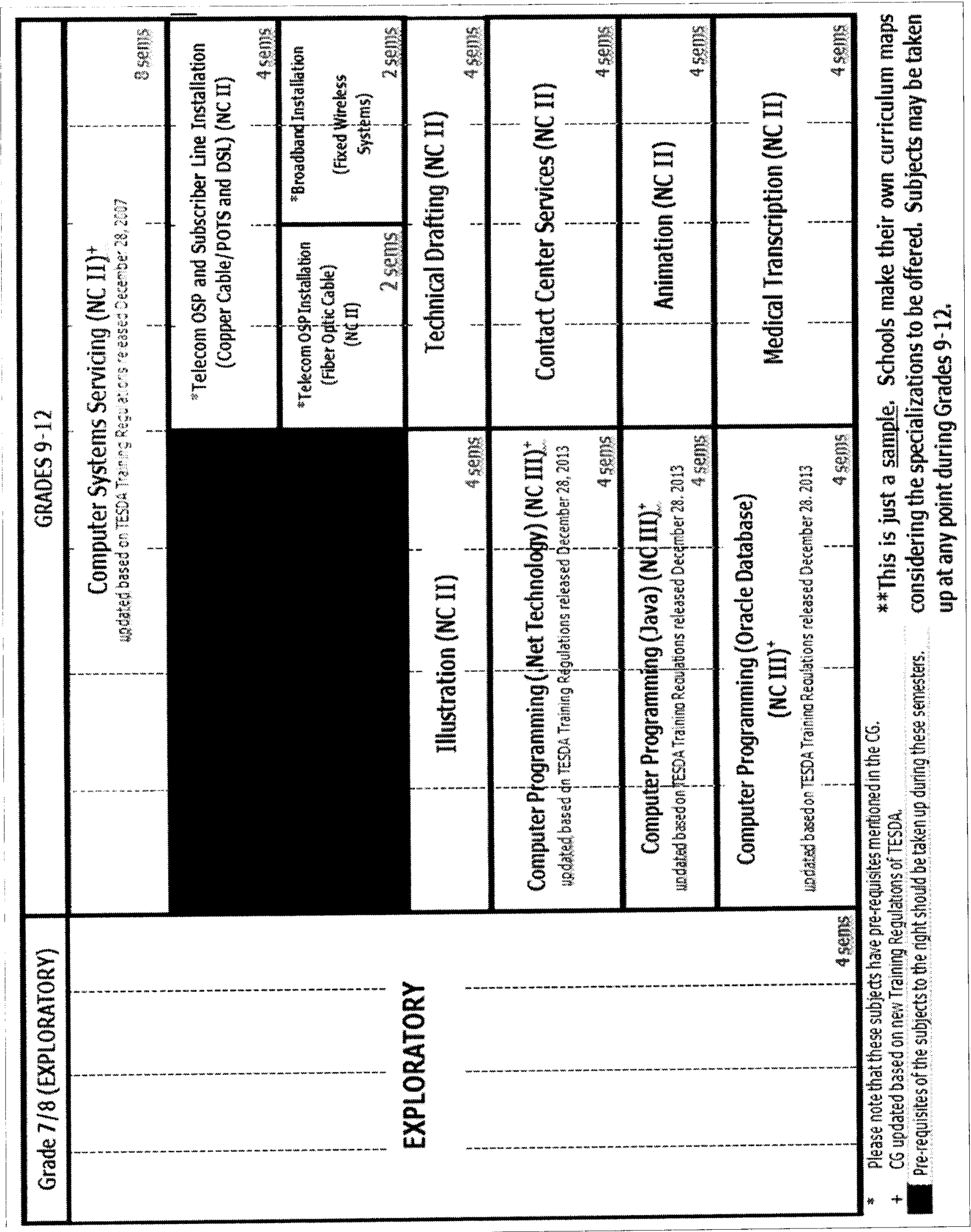

Figure 2.4: Sample Curriculum Map for TVL Track: Information and Communications Technology (ICT) Strand 


\section{Work Immersion/Research/Career Advocacy/Culminating Activity}

57. Regardless of track or strand, each specialization has one 80-hour subject slot where learners may take up Work Immersion/Research/Career Advocacy or a Culminating Activity. These options serve as avenues to apply and showcase the skills they have learned during SHS. However, the subject to be offered will depend on the school's capability. In terms of Work Immersion in TVL, the schools may opt to utilize various delivery models. Table 2.22 A illustrates these delivery models. The examples referred to (Models B1, B2 and so on) can be found in DepEd Order No. 30, s. 2017.

Table 2.22 A: Work Immersion Delivery Models

\begin{tabular}{|c|c|c|c|c|}
\hline Models & $\begin{array}{c}\text { Work } \\
\text { Immersion } \\
\text { Hours }\end{array}$ & $\begin{array}{l}\text { Learner's Purpose } \\
\text { and Needs }\end{array}$ & School & Options \\
\hline Model A & $\begin{array}{l}80 \text { hours } \\
\text { (This is the } \\
\text { minimum } \\
\text { requirement } \\
\text { for Work } \\
\text { Immersion.) }\end{array}$ & $\begin{array}{l}\text { For learners who } \\
\text { only need } 80 \text { hours } \\
\text { of work immersion }\end{array}$ & $\begin{array}{l}\text { Has partners } \\
\text { that only } \\
\text { accommodate } \\
80 \text { hours of } \\
\text { Work } \\
\text { Immersion }\end{array}$ & \\
\hline \multirow[t]{3}{*}{ Model B } & \multirow[t]{3}{*}{$\begin{array}{l}240 \text { hours } \\
(80+160 \\
\text { hours })\end{array}$} & \multirow[t]{3}{*}{$\begin{array}{l}\text { Optional for } \\
\text { learners who: } \\
\text { 1. decide to do } \\
\text { more Work } \\
\text { Immersion } \\
\text { hours in the } \\
\text { specialization } \\
\text { of their choice; } \\
\text { and } \\
\text { 2. have more } \\
\text { Work } \\
\text { Immersion } \\
\text { opportunities } \\
\text { available. }\end{array}$} & \multirow[t]{3}{*}{$\begin{array}{l}\text { Has several } \\
\text { Work } \\
\text { Immersion } \\
\text { partners that } \\
\text { can } \\
\text { accommodate } \\
\text { all its learners } \\
\text { in the first and } \\
\text { second } \\
\text { semester of } \\
\text { Grade } 12\end{array}$} & $\begin{array}{l}\text { 1. Learners may start } \\
\text { taking a } 640 \text {-hour } \\
\text { specialization in Grade } \\
9 \text { and finish at Grade } \\
11 \text { For Grade } 12 \text {, } \\
\text { s/he may take up } \\
\text { another } 160 \text {-hour } \\
\text { specialization before } \\
\text { or after the Work } \\
\text { Immersion. } \\
\text { Examples are shown } \\
\text { in Models B1 and B2. }\end{array}$ \\
\hline & & & & $\begin{array}{l}\text { 2. Learners may start } \\
\text { taking a } 320 \text {-hour } \\
\text { specialization at Grade } \\
11 \text {. For Grade } 12 \text {, } \\
\text { s/he may take up } \\
\text { another } 160 \text {-hour } \\
\text { specialization before } \\
\text { or after the work } \\
\text { immersion. } \\
\text { Examples are shown } \\
\text { in Models B1 and B3. }\end{array}$ \\
\hline & & & & $\begin{array}{l}\text { 3. Learners may also } \\
\text { take up three } 160-\end{array}$ \\
\hline
\end{tabular}




\begin{tabular}{|c|c|c|c|c|}
\hline Models & $\begin{array}{c}\text { Work } \\
\text { Immersion } \\
\text { Hours }\end{array}$ & $\begin{array}{l}\text { Learner's Purpose } \\
\text { and Needs }\end{array}$ & School & Options \\
\hline & & & & $\begin{array}{l}\text { hour specializations } \\
\text { starting Grade } 11 \text {. } \\
\text { Work Immersion may } \\
\text { be done during the } \\
\text { second semester of } \\
\text { Grade } 12 \text {. } \\
\text { An example is shown } \\
\text { in Model B4. }\end{array}$ \\
\hline \multirow[t]{2}{*}{ Model C } & \multirow[t]{2}{*}{$\begin{array}{l}240 \text { hours } \\
\text { distributed } \\
\text { over several } \\
\text { terms }\end{array}$} & \multirow[t]{2}{*}{$\begin{array}{l}\text { Optional for } \\
\text { learners who: } \\
\text { 1. decide to do } \\
\text { more Work } \\
\text { Immersion } \\
\text { hours in the } \\
\text { specialization } \\
\text { of their choice; } \\
\text { 2. have more } \\
\text { Work } \\
\text { Immersion } \\
\text { opportunity } \\
\text { available; and } \\
\text { 3. are enrolled in } \\
\text { specializations } \\
\text { that require } \\
\text { more training } \\
\text { hours. }\end{array}$} & \multirow[t]{2}{*}{$\begin{array}{l}\text { Has Work } \\
\text { Immersion } \\
\text { venues but } \\
\text { these cannot } \\
\text { accommodate } \\
\text { all learners in } \\
\text { the } \\
\text { semester of } \\
\text { Grade } \\
\text { hence making it } \\
\text { necessary to } \\
\text { spread out the } \\
\text { immersion over } \\
\text { several terms }\end{array}$} & $\begin{array}{l}\text { 1. For a } 640 \text {-hour } \\
\text { specialization, } \\
\text { learners may take the } \\
\text { first } 320 \text { hours in } \\
\text { Grade } 11 \text { then have } \\
120 \text { hours of Work } \\
\text { Immersion during } \\
\text { summer. } \\
\text { They may then take up } \\
160 \text { specialization } \\
\text { hours during the first } \\
\text { semester of Grade } 12 \\
\text { and have } 40 \text { hours of } \\
\text { Work Immersion } \\
\text { during the semestral } \\
\text { break. } \\
\text { Learners may then } \\
\text { take up the remaining } \\
160 \text { specialization } \\
\text { hours during the } \\
\text { second semester of } \\
\text { Grade } 12 \text { and have } 80 \\
\text { hours of } \text { Work } \\
\text { Immersion. } \\
\text { An example is shown } \\
\text { in Model C1. }\end{array}$ \\
\hline & & & & $\begin{array}{l}\text { 2. Another option for } \\
\text { a } 640 \text {-hour } \\
\text { specialization is for } \\
\text { learners to take } 320 \\
\text { hours of specialization } \\
\text { in Grade } 11 \text { and have } \\
160 \text { hours of Work }\end{array}$ \\
\hline
\end{tabular}




\begin{tabular}{|c|c|c|c|c|}
\hline Models & $\begin{array}{c}\text { Work } \\
\text { Immersion } \\
\text { Hours }\end{array}$ & $\begin{array}{c}\text { Learner's Purpose } \\
\text { and Needs }\end{array}$ & School & Options \\
\hline & & & & $\begin{array}{l}\text { Immersion during } \\
\text { summer. } \\
\text { S/he may then take } \\
\text { up } 320 \text { hours of } \\
\text { specialization during } \\
\text { the first semester of } \\
\text { Grade } 12 \text { and have } 80 \\
\text { hours of Work } \\
\text { Immersion during the } \\
\text { second semester. } \\
\text { An example is shown } \\
\text { in Model C2. }\end{array}$ \\
\hline \multirow[t]{2}{*}{ Model D } & \multirow[t]{2}{*}{$\begin{array}{l}320 \text { hours } \\
\text { distributed } \\
\text { over several } \\
\text { terms } \\
(80+240 \\
\text { hours) }\end{array}$} & \multirow[t]{2}{*}{$\begin{array}{l}\text { Optional for } \\
\text { learners who: } \\
\text { 1. are likely to } \\
\text { proceed to } \\
\text { employment } \\
\text { after basic } \\
\text { education; } \\
\text { 2. decide to do } \\
\text { more Work } \\
\text { Immersion } \\
\text { hours in the } \\
\text { specialization } \\
\text { of their choice; } \\
\text { and have Work } \\
\text { 3. have Immersion } \\
\text { opportunities } \\
\text { available to } \\
\text { them. }\end{array}$} & \multirow[t]{2}{*}{$\begin{array}{l}\text { Has partners } \\
\text { who have more } \\
\text { Work } \\
\text { Immersion slots } \\
\text { Has select } \\
\text { learners who } \\
\text { are ready for } \\
\text { more training in } \\
\text { the workplace }\end{array}$} & $\begin{array}{l}\text { 1. For a } 480 \text {-hour } \\
\text { specialization and } \\
\text { work immersion for } \\
320 \text { hours, learners } \\
\text { may take up } 320 \\
\text { specialization hours in } \\
\text { Grade } 11 \text { and have } 80 \\
\text { hours of Work } \\
\text { Immersion during } \\
\text { summer. } \\
\text { S/He may then take } \\
\text { the remaining } 160 \\
\text { specialization hours in } \\
\text { the first semester of } \\
\text { Grade } 12 \text { and have } \\
240 \text { hours of Work } \\
\text { Immersion in the } \\
\text { second semester. } \\
\text { A sample is shown in } \\
\text { Model D } 1 \text { below. }\end{array}$ \\
\hline & & & & $\begin{array}{l}\text { 2. Learners may finish } \\
\text { a } 320 \text {-hour } \\
\text { specialization in Grade } \\
11 \text { and have } 40 \text { hours } \\
\text { of Work Immersion } \\
\text { during summer. } \\
\text { Learners may then } \\
\text { continue their Work } \\
\text { Immersion in the } 320- \\
\text { hour specialization in }\end{array}$ \\
\hline
\end{tabular}




\begin{tabular}{|c|c|c|c|c|}
\hline Models & $\begin{array}{c}\text { Work } \\
\text { Immersion } \\
\text { Hours }\end{array}$ & $\begin{array}{c}\text { Learner's Purpose } \\
\text { and Needs }\end{array}$ & School & Options \\
\hline & & & & $\begin{array}{l}\text { the first semester of } \\
\text { Grade } 12 \text { for } 240 \\
\text { hours and during } \\
\text { semestral break for } 40 \\
\text { hours. } \\
\text { S/He may then take } \\
\text { up another 160-hour } \\
\text { specialization during } \\
\text { the second semester of } \\
\text { Grade } 12 \text {. } \\
\text { A sample is shown in } \\
\text { Model D2. }\end{array}$ \\
\hline
\end{tabular}

58. Curriculum Guides with activity examples for each track or strand may be downloaded from the DepEd website. Table 2.22 B lists these sample activities.

Table 2.22 B: Sample Activities for Each Track or Strand

\begin{tabular}{|l|l|}
\hline \multicolumn{1}{|c|}{ Track/Strand } & \multicolumn{1}{c|}{ Sample Activity* } \\
\hline ABM & Business Enterprise Simulation \\
\hline HUMSS & Culminating Activity \\
\hline STEM & Research/Capstone Project \\
\hline Arts and Design & Performing Arts Production/Exhibit for Arts Production \\
\hline Sports & Apprenticeship (off-campus) \\
\hline TVL & Work Immersion** \\
\hline
\end{tabular}

*These are only examples. These activities may be applied to other tracks or strands. Schools may also design their own activities.

**Guidelines for Work Immersion may be found in DepEd Order No. 30, s. 2017.

\section{Senior High School (SHS) Curriculum Flexibilities}

59. The SHS Curriculum is already in place and a set list of subjects make up the SHS Core, Applied Track and Specialized Track Subjects. However, the following flexibilities are allowed:

\section{For Core Subjects}

60. In Grades 11 and 12, students shall take 15 core subjects. The core subjects are based on the eight learning areas and taken by all SHS learners: 1) Language; 2) Humanities; 3) Communication; 4) Mathematics; 5) Philosophy; 6) Science; 7) Social Science; and 8) Physical Education and Health.

61. Every subject in the core curriculum is compulsory and has a time allocation of 80 hours.

62. However, curriculum flexibility allows for two subject substitutions, provided that the replacement subjects must have the same competencies with the 
subjects to be replaced. For example, Oral Communication may be substituted with a similar subject such as Speech and Discourse for as long as the competencies that are supposed to be developed in Oral Communication are also developed through the alternate subject.

63. Regardless of program offering, there should be at least 13 subjects consistent, in content and competencies, with the approved SHS curriculum and must use the approved curriculum guides.

\section{For the Specialized Track Subjects}

64. In Grades 11 and 12, students shall take 9 specialized or 9 subjects totaling 720 hours. The specialized track subjects contain different curriculum content and competencies that are unique to the chosen track and strand. Curriculum flexibility for the specialized track subjects can be done in several ways:

a. Allow for three subject substitutions, provided that the replacement subjects are related to the field of specialization. For example, in HUMSS, 3 subjects may be replaced by other HUMSS subjects which may be more related to the college course that learners will pursue after SHS.

b. Provide for various models for work immersion. See DepEd Order No. 30, s. 2017 for reference.

c. Allow for the creation of a new set of 9 specialization subjects which follow the Curriculum Development Process (a separate issuance will be released regarding this process).

d. For the General Academic Strand, there should be at least four subjects consistent in content and competencies, with the approved SHS curriculum. This is so because GAS allows for two electives. If the electives are to be taken from the other academic strands or TVL specializations, such electives must be consistent in content and competencies with the approved SHS curriculum and use the approved curriculum guides.

\section{E. Assessment in SHS}

65. Classroom assessment in SHS consists of formative and summative classroom assessments given during Grades 11 to 12 to improve student learning outcomes. The processes may be found in DepEd Order No. 8, s. 2015 Learners are given feedback about their performance to help them choose their career paths. DepEd Order No. 36, s. 2016 on honors provides schools the mechanisms for giving awards and recognition to the talents and effort of learners.

66. The assessment of student learning is discussed in greater detail in DepEd Order No. 55, s. 2016, entitled Policy Guidelines for the National Assessment of Student Learning for the K to 12 Basic Education Program.

\section{FEATURES OF SECONDARY EDUCATION}

67. Besides the core curricula, the Secondary Education Curriculum also offers a variety of school programs to secondary education learners aimed at their holistic development. These include Special Curricular Programs (SCPs), Homeroom Guidance Program (HGP), Citizenship Training Program (CTP), Secondary Schools for specific purposes, Co-curricular Activities in Secondary Education, Special 
Education and Flexible Learning Options (FLOs). They are described and discussed in this section.

\section{Special Curricular Programs (SCPs)}

68. The SCPs "have been designed to enable students to understand their strengths, pursue their interests, and develop their multiple intelligences (DepEd Memorandum No. 149, s. 2011)." Through SCPs, it is envisioned that DepEd will produce globally-competitive learners imbued with desirable values and equipped with 21 st century skills that can contribute to nation-building and national transformation while preserving Filipino culture, heritage and identity.

69. Specifically, these SCPs aim to provide high school learners with a foundation for a career pathway that is aligned with their interests and aptitudes. In JHS, the SCPs will no longer take the place of TLE; instead, the SCP will be treated as an additional subject. The delivery of TLE shall be contextualized to the SCP being taken up by the learners. For example, if the student is taking Special Program in the Arts (SPA), the student's TLE will focus more on making costumes and designing animations that will be useful in the SCP subject. Some SCPs, such as Special Program in Foreign Language (SPFL) and Special Program in Journalism (SPJ), may be offered as an elective in the General Academic Strand (GAS). Table 2.23 lists and describes the different SCPs:

\section{Table 2.23: Special Curricular Programs (SCPs)}

\begin{tabular}{|c|l|l|}
\hline No. & \multicolumn{1}{|c|}{ SCP } & \multicolumn{1}{c|}{ Program Description } \\
\hline 1 & $\begin{array}{l}\text { Special Program } \\
\text { in the Arts } \\
\text { (SPA) }\end{array}$ & $\begin{array}{l}\text { SPA provides learners with a chance to develop and } \\
\text { enhance their talents in the following art fields: Visual } \\
\text { Arts, Music, Theatre Arts, Dance Arts, Media Arts, and } \\
\text { Creative Writing (English and Filipino). SPA aims to create } \\
\text { young artists with aesthetic potentials who will preserve } \\
\text { and enrich Filipino culture and heritage. }\end{array}$ \\
\hline 2 & $\begin{array}{l}\text { Special Program } \\
\text { in Foreign } \\
\text { Language } \\
\text { (SPFL) }\end{array}$ & $\begin{array}{l}\text { SPFL provides learners with educational opportunities to } \\
\text { learn a foreign language. SPFL aims to develop students' } \\
\text { skills in listening, reading, writing, speaking, and viewing } \\
\text { in a foreign language; develop their understanding of and } \\
\text { appreciation for other peoples' cultures; and prepare them } \\
\text { for meaningful interaction in a linguistically and culturally } \\
\text { diverse workplace. Schools with SPFL offer at least one of } \\
\text { the following languages: Spanish, Japanese, French, } \\
\text { German, Chinese (Mandarin), and Korean. }\end{array}$ \\
\hline 3 & $\begin{array}{l}\text { Special Program } \\
\text { in Journalism } \\
\text { (SPJ) }\end{array}$ & $\begin{array}{l}\text { SPJ develops learners with a talent in writing and } \\
\text { broadcasting. The program aims to enrich the experiences, } \\
\text { hone the journalistic skills and competencies of student- } \\
\text { writers, and strengthen free and responsible journalism. } \\
\text { SPJ is designed to develop learners' skills in mass } \\
\text { communication, print, online, and broadcast media. }\end{array}$ \\
\hline 4 & $\begin{array}{l}\text { SPS is offered to learners who want to develop their talents } \\
\text { in different sports disciplines. SPS provides training for } \\
\text { athletes to be able to compete in national and international } \\
\text { sports competitions. Schools that offer SPS should have a } \\
\text { minimum of five individual/dual sports (Archery, Arnis, } \\
\text { Badminton, Chess, Gymnastics, Table } \\
\text { Sponnis, }\end{array}$ \\
\hline
\end{tabular}




\begin{tabular}{|c|l|l|}
\hline No. & \multicolumn{1}{|c|}{ SCP } & \multicolumn{1}{c|}{ Program Description } \\
\hline 5 & $\begin{array}{l}\text { Science, } \\
\text { Technology, } \\
\text { and } \\
\text { Engineering } \\
\text { (STE) Program } \\
\text { sports (Baseball, Basketball, Football, Sepak Takraw, } \\
\text { Softball or Volleyball). }\end{array}$ \\
\hline 6 & $\begin{array}{l}\text { STE, formerly known as Engineering and Science } \\
\text { Education Program (ESEP), offers learners with an } \\
\text { enriched science and technology-oriented curriculum that } \\
\text { will prepare them for higher education or work in the areas } \\
\text { of science, technology, and engineering. }\end{array}$ \\
$\begin{array}{l}\text { Vocational } \\
\text { Education } \\
\text { (SPTVE) }\end{array}$ & $\begin{array}{l}\text { SPTVE is a special curricular program that provides the } \\
\text { complete development of the individual as a total person } \\
\text { equipped with technical-vocational and academic } \\
\text { competencies, proper work ethic and desirable values that } \\
\text { will make the learner economically stable, responsible, } \\
\text { law-abiding, productive and competitive in the world of } \\
\text { work. It provides opportunities for Junior High School } \\
\text { students to acquire the necessary skills and } \\
\text { competencies, and qualifications to empower them for } \\
\text { further specialization in Technical-Vocational-Livelihood } \\
\text { (TVL) courses in Senior High School. }\end{array}$ \\
\hline
\end{tabular}

\section{The Homeroom Guidance Program (HGP)}

70. The Homeroom Guidance Program (HGP) operates on the belief that every student is unique, and has abilities to develop oneself using one's learnings and experiences, and with support from school, family, community, government, and other institutions.

71. The HGP shall address the academic, personal/social and career needs of the students in a developmental, comprehensive and proactive manner, in order to produce students who understand themselves, respect individual differences, make informed decisions, have problem-solving skills, and are able to achieve academic success and plan for their future. Furthermore, it envisions to prepare learners to work for the common good of society while upholding international standards.

72. The subject is handled by a class adviser who is expected to maintain a congenial relationship with learners and promote a safe and interactive atmosphere for the class.

\section{Citizenship Training Program (CTP)}

73. The Citizenship Training Program (CTP) is a restructuring of the Citizens Army Training and the Citizenship Advancement Training (CAT). It aims to enhance learners' social responsibility and commitment to the development of their communities. It also intends to develop their abilities to uphold law and order as they actively lead and participate in activities and projects for community development, and assist the government especially in times of emergency. It shall be a separate learning area in Grade 10.

74. The CTP has two components:

a. Basic Leadership provides learning opportunities to gain knowledge, 
skills, and understanding on the rights and duties of citizens, and on military orientation with emphasis on leadership, followership, and personal discipline.

b. Public Safety provides basic knowledge of and skills development in public safety, and prepares students for emergencies. It encompasses all programs and activities that contribute to the maintenance of peace and order, promote public health and safety and Disaster Risk Reduction Management (DRRM), and encourage observance of and compliance to laws.

75. A separate CTP policy issuance will be released.

\section{Secondary Schools for Specific Purposes}

76. There are specialized Secondary Schools created to respond to the goals, aspirations, and needs of a community and its members. These schools may be mandated by law or be determined by the DepEd.

\section{a. Regional Science High Schools (RSHS)}

77. Regional Science High Schools (RSHS) are separate schools designed to provide a more intensive and advanced secondary education program for scienceinclined and intellectually advanced learners with the objective of fostering critical thinking through the problem-solving approach. The RSHS have enriched science, mathematics, and English curricula in addition to the existing Secondary Education Curriculum.

\section{b. Sports Academies}

78. Sports Academies for students who are gifted and talented in the field of human kinetics and sports may be organized for each region or province. Guidelines for the creation of these academies are in development. The curriculum development process and the preparation for the provision of the curriculum support system unique to the needs of athletes and sports professionals will be included in these guidelines.

\section{c. Schools for Arts and Design}

79. Schools for Arts and Design for students who are gifted and talented in the disciplines of arts and design may be organized for each region or province. Guidelines for the creation of these schools are in development. The curriculum development process and the preparation for the provision of the curriculum support system unique to the needs of artists and design professionals will be included in these guidelines.

\section{d. Rural Farm Schools}

80. The Rural Farm School (RFS) program aims to provide a facilitative and experiential learning on the core subjects of the secondary education curriculum with focus on agri-fisheries, designed to address the needs of learners in rural, agricultural, and fishing communities. It targets learners who are children of farmers and fisherfolk in the locality. It also gives priority to Comprehensive Agrarian Reform 
Program (CARP) beneficiaries or farmers who had received certificates of land ownership. The implementation guidelines of the program will be discussed in detail in another issuance.

\section{e. Multigrade Secondary Schools}

81. To ensure that their learners are provided with complete basic education, some secondary/integrated schools continue to implement the Multigrade Education Program. These schools typically have fewer enrollments and are usually found in rural and remote communities. Following the setup in elementary level Multigrade Education Programs, learners from various secondary grade levels are grouped as one class, which is handled by one teacher. Provision of adequate learning resources and environment is essential to ensure that standards of the secondary curriculum are met. Policy guidelines for multigrade secondary schools will be developed and released as a separate issuance.

\section{Co-curricular Activities in Secondary Education}

82. To provide learners with opportunities to exhibit their learning, the DepEd holds annual competitions at the school, schools division, regional, and national levels. These competitions are discussed in this section.

\section{a. National Schools Press Conference}

83. The National Schools Press Conference (NSPC) is DepEd's competition for campus journalists. The NSPC is mandated by Republic Act No. 7079 or the Campus Journalism Act of 1991, which directs DepEd to hold "periodic competitions, press conferences and training seminars in which student-editors/writers and teacher-adviser of student publications in the elementary, secondary and tertiary levels shall participate. Such competitions, conferences and seminars shall be held at the institutional, divisional, and regional levels, culminating with the holding of the annual national elementary, secondary or tertiary School Press Conferences in places of historical and/or cultural interest in the country."

84. Through the NSPC, DepEd provides a venue for an enriching learning experience for students interested in journalism as a career, promotes responsible journalism and fair and ethical use of various media, and enhances journalistic competence through healthy and friendly competitions. Furthermore, young campus journalists are expected to demonstrate an understanding of the importance of journalism by expressing it through different journalistic endeavors and approaches, and sustain advocacy on social consciousness and environmental awareness.

85. The NSPC has expanded its competition from the usual print category to online and broadcast (TV and radio) categories. To accommodate schools that cannot print their own paper, electronic copies (pdf) are being considered as entries in the school paper contest.

\section{b. National Festival of Talents}

86. The National Festival of Talents (NFoT) aims to provide secondary school learners with opportunities to showcase their talents through exhibitions of their products and performances as evidence of their learning, and extend parallel learning sessions for teachers and learners to enhance their knowledge and skills in their respective fields of interest. 
87. The NFoT has skills exhibition in different fields, namely, Technolympics (Technology and Livelihood Education), Sining Tanghalan (Arts), National Population Quiz and On-the-Spot Skills Exhibition on PopDev (Araling Panlipunan), Pambansang Tagisan ng Talino (Filipino), and Foreign Language Skills Showcase (Special Program in Foreign Language). It also includes Musabaqah, an activity primarily for learners who attend Arabic Language and Islamic Values Education (ALIVE) classes, to demonstrate their competencies in the learning area.

\section{c. National Science and Technology Fair}

88. The National Science and Technology Fair (NSTF) aims to promote Science and Technology consciousness among the youth and identify the most creative or innovative Science researchers who will represent the country in international competitions like the Intel International Science and Engineering Fair (Intel ISEF).

89. As a research competition, the NSTF encourages young scientists to conduct investigative studies in life science, physical science, and robotics. Mathematics and engineering-related projects fall under the physical science category.

\section{d. Palarong Pambansa}

90. The Palarong Pambansa (or Palaro) is an annual multilevel national scholastic athletic competition conducted by DepEd and participated in by elementary and secondary learners from public and private schools. The Palaro was institutionalized through Republic Act No. 10588, or the Palarong Pambansa Act of 2013, and serves as a laboratory of learned or acquired knowledge, skills, and attitudes in Physical Education and school sports programs. It provides athletic young learners opportunities to improve their physical, moral, intellectual, and social well-being, and serves as a means to promote education, health, development, and peace.

91. The Palaro also seeks to instill the spirit of discipline, teamwork, excellence, fair play, solidarity, sportsmanship, and other values inherent in sports among student-athletes. It has served as a platform for talent identification, selection, recruitment, training and exposure of elementary and secondary student athletes. Through the Palaro, the DepEd promotes Physical Education and Sports as an integral part of the Basic Education Curriculum and affirms the schools' commitment to the full development of the potential of young learners to become responsible and globally competitive citizens.

\section{Special Education}

92. In the secondary level, appropriate Special Education (SpEd) programs and services are provided for learners with disabilities. These programs and services refer to academic interventions, curriculum adaptations, learning resource support, career and guidance counseling programs, and transition programs focusing on technical-vocational competencies and/or special interest skills development. To address the learners' health and medical conditions, schools' referral system to medical and allied medical-service providers is an essential part of SpEd services. This will only be possible through strong school-community collaboration and partnerships with parents and families, local government units, and nongovernment 
agencies and civic organizations.

93. Proper assessment and identification of strengths, difficulties and interests are essential in planning for the appropriate transition program and Individualized Education Plan (IEP) for learners with disabilities. The guidance and counseling program gives direction and support to learners in preparation for adulthood, identification and accomplishment of goals in the IEP, and learners' transition to school-work, home, or community life.

94. To ensure that learners have access to the $\mathrm{K}$ to 12 basic education program, curriculum contextualization, adaptations, and modifications are made depending on the learner's abilities and needs. This is possible when time allotment for learning areas and subjects in junior and senior high school are adjusted and/or extended. Another example is the Adaptive Physical Education (PE), wherein PE teachers modify and prepare activities to include learners with disabilities. Learners with disabilities also access the curriculum when they are provided with and supported by learning resources and assistive devices and technologies. These include sign language interpreters, materials in Braille, wheelchairs, and hardware and software systems, among others.

95. On the other hand, the transition program prepares learners to successfully move forward from home to school, class to class, and/or from school to another school for higher education or middle-level skills development. The program may also help learners transition to employment and entrepreneurship. For more information, please refer to the policy on learners with disabilities.

\section{Flexible Learning Options}

96. Flexible Learning Options (FLOs) for both Elementary and Secondary education are discussed in Annex 3. 


\section{References}

Association for Middle Level Education. (n.d.). Developmental Characteristics of Young Adolescents. Retrieved 1 August 2016, from https://www.amle.org/BrowsebyTopic/WhatsNew/WNDet/TabId/270/A rtMID/888/ArticleID/455/Developmental-Characteristics-of-YoungAdolescents.aspx

Centers for Disease Control and Prevention (n.d.). Child Development. Retrieved August 1, 2016 http://www.cdc.gov/ncbddd/childdevelopment/positiveparenting/adole scence $2 . h t m l$

Committee on the Rights of the Child. General comment no. 4: Adolescent health and development in the context of the Convention on the Rights of the Child. Accessed 1 August 2014.www.unicef.org/CRCCommitAdolesc.doc.

Convention on the Rights of the Child. Accessed 1 August 2014. http://www.ohchr.org/en/professionalinterest/pages/crc.aspx.

DECS Order No. 11, s. 1989 Implementation of the New Secondary Education Curriculum under the 1989 Secondary Development Program

DepEd Memorandum No. 149, s. 2011 Career Pathways for High School Students

DepEd Order No. 31, s. 2012 Policy Guidelines on the Implementation of Grades 1 to 10 of the K to 12 Basic Education Curriculum (BEC) Effective School Year 2012-2013

DepEd Order No. 55, s. 2016 Policy Guidelines for the National Assessment of Student Learning for the K to 12 Basic Education Program

DepEd Order No. 35, s. 2003 Implementation of the Citizenship Advancement Training (CAT) at the Fourth Year High School Level

DepEd Order No. 50, s. 2005 Revised Implementing Guidelines on the Implementation of Citizenship Advancement Training (CAT) in Both Public and Private Secondary Schools

DECS Order No. 69, s. 1993 Science High Schools

DECS Order No. 55, s. 1994 Curriculum in the Regional Science High Schools

DECS Order No. 67, s. 1997 Implementation of the Revitalized Homeroom Guidance Program (RHGP) for SY 1998-1999

DECS Order No. 52, s. 1998 Guidelines on the Implementation of the Revitalized Homeroom Guidance Program (RHGP) and the System of Rating and Reporting Student Performance Under the RHGP 
Papalia, D.E. \& Olds, S.W. (1995). Human Development. New York: McGraw-Hill Book Company.

Psychology Today (n.d.). Adolescence. Retrieved 1 August 2016 from https://www.psychologytoday.com/intl/basics/adolescence

Republic Act No. 7079, s. 1991 An Act Providing for the Development and Promotion of Campus Journalism and for Their Purposes

State Adolescent Health Resource Center. (n.d.). Health \& Development. Retrieved August 1, 2016, from hros:/sites.google.com/a/umn.edu/sahre-3-22-17/home/healthdevelopment-1

UNICEF (1990). Education for all. Retrieved August 1, 2014 from http://www.unicef.org/education/index_44870.html.

UNICEF (2011). State of the world's children. Retrieved 1 August 2014 from http://www.unicef.org/sowc2011/.

UNICEF (2016). State of the world's children. Retrieved 1 October 2016 from https://www.unicef.org/sowc2016/

World Bank. Republic of the Philippines Alternative Learning System Study.

World Health Organization (2014). Health for the world's adolescents. Retrieved August 1, 2014 from http://www.who.int/maternal_child_adolescent/ topics/adolescence/second-decade/en/. 


\section{ANNEX 3: FLEXIBLE LEARNING OPTIONS: ADMs and ALS}

1. Flexible Learning Options (FLOs) provide a menu of learning interventions and pathways that are responsive to the needs, context, circumstances, and diversity of learners. FLOs allow for variations in organization, approaches and modalities of teaching and learning. This flexibility is helpful for learners who are at risk of dropping out, children and youth who are out of school, adults who failed to finish basic education, learners with special needs, learners with extreme difficulty in accessing schools or those who attend overpopulated schools, and learners in emergency situations.

2. There are two main categories of FLOs: the Alternative Delivery Modes or ADMs and the Alternative Learning System or ALS.

\section{ADMs}

3. Alternative Delivery Modes (ADMs) are instructional or learning modalities that do not strictly follow the typical set-up for regular classroom instruction, but follow the formal $\mathrm{K}$ to 12 curriculum in content. Formal curriculum refers to the curriculum starting at Kindergarten and ending at Grade 12 that learners undergo through successive grade levels.

4. The flexibility in instructional or learning modalities of ADMs is in terms of the time and duration of instruction, the place of instruction, or the method of instruction. Instruction may be face-to-face learning, where the teacher and learner/s are physically in one venue during lessons, distance learning, where a learner is given materials or access to resources and s/he undertakes selfdirected study at home or in another venue, or blended learning, a combination of face-to-face and distance modalities.

5. All public elementary and secondary schools should be ready to offer ADMs for all types of learners whenever the need arises. They are required to inform their Schools Division Office through a letter addressed to the SDS everytime a new ADM is offered by the school.

6. Private schools are similarly allowed to offer ADMs after securing a permit to offer from their Regional Office. The requirements for acquiring a permit include a letter of intent addressed to the Regional Director through the Schools Division Superintendent, and an implementation plan that describes the target learners for the ADM, the training plan for parents, and the learning resources. A school coordinator must also be identified for every ADM that the school will offer.

7. The learning resources for the $\mathrm{K}$ to 12 program are also used for ADMs. However, distance or blended learning may require learning resources that are designed for independent or self-paced study. These may be in the form of modules made available through ICT or other technological tools.

8. The ongoing ADMs of DepEd are as follows:

\section{A. Home School}

9. Home schooling provides learners with access to formal education while staying in an out-of-school environment. Authorized parents, guardians, or tutors take the place of the teachers as learning facilitators. While learners are expected to 
meet the learning standards of the $\mathrm{K}$ to 12 Basic Education Curriculum, the learning facilitators are given flexibility in learning delivery, scheduling, assessment, and curation of learning resources. The program aims to cater to learners who may require home schooling because of their unique circumstances, such as illness, frequent travelling, special education needs, and other similar contexts. Moreover, the program allows parents and guardians to maximize their involvement in their children's education as a matter of parenting philosophy.

10. Parents or guardians who opt to enroll their children in a home school program should do so through a public school, or through a private school that had been given a permit to offer a home school program. These schools will be in charge of ensuring the following:

a. that a parent or guardian is assigned as a learning facilitator;

b. that the learner is registered through the Learner Information System (LIS);

c. that learning materials and resources are available for the learner; and

d. the School Form 9 and other pertinent school records are issued to homeschoolers.

11. Alternatively, learners may be enrolled through home school providers, which are learning centers or institutions that provide home schooling. To facilitate the registration of learners through the Learner Information System (LIS), these providers may either find a DepEd accredited partner school, or they may coordinate with the SDO directly.

\section{B. Instructional Management by Parents, Community, and Teachers (IMPACT)}

12. The development of IMPACT as an alternative delivery mode has been facilitated by the Southeast Asia Ministers of Education Organization Regional Center for Educational Innovation and Technology (SEAMEO INNOTECH) in the early 1970s in response to the common problems faced by the member states in their respective education systems. These problems include unequal access to high-quality education, high dropout rates, low cohort survival rates, and declining learning achievements, among others. IMPACT was thus designed to effectively address these issues while maximizing the states' limited economic resources; by providing space for both independent and collaborative learning, and by empowering families to support their children's education through tutoring and monitoring of their progress, the program pools together the resources of the schools and their immediate communities to extend the reach and improve the quality of the education system.

13. In the Philippines, IMPACT is available for elementary schools only. Schools that offer this learning option must group learners from varying grade levels into learning families, which consist of 50 to 60 learners each; ideally, learners should be placed in the same learning family as their siblings/relatives, neighbors, and friends, so that the members of the group are naturally accountable for one other's attendance and progress in school. Teachers will function as instructional supervisors who will oversee the learning of 1-2 learning families.

14. IMPACT allows for three modes of learning delivery, namely Programmed Teaching, (2) Peer Group Learning, and (3) Self-Instruction. 
15. Programmed Teaching is available for learners in Grades 1 to 3 . The content and delivery of lessons are pre-arranged through Learning Modules, and are presented by selected learners from Grades 4 to 6 . These selected learners will be trained by the instuctional supervisors to teach half of the required lesson for one subject. The schedule of learners who will be assigned to teach must be given at least a week ahead to allow them to prepare the learning materials and to practice their delivery. This arrangement allows for the instructional supervisor to attend to more learners, while also giving an opportunity for able Grades 4 to 6 learners to enhance their mastery of the competencies they teach.

16. Peer Group Learning, on the other hand, is available for learners from Grades 4 to 6 . Within learning families, learners are further grouped into peer groups with 5-6 members of varying assessed learning levels, as determined through a diagnostic test. Each group will study the same set of modules at their appropriate pace; learners will take turns in leading the discussions, although the ones who have performed well in diagnostic tests will be assigned to lead first. This arrangement gives space for learners to develop skills in collaboration and leadership.

17. In addition, when peer groups finish the learning modules, they will meet as one class and will be handled by a Resource Teacher, who will deliver enrichment classes and introduce audio-visual materials to the learners.

18. Finally, Self-Instruction can be availed by Grade 4 to 6 learners in two ways. For those who are able to regularly attend the peer group meetings, they are given an hour a day for independent learning. During this time, learners are tasked to either review the modules they have already accomplished, or to prepare for the next module. The instructional supervisor is also expected to assist learners through remediation if necessary. If equipment is available, learners will also be allowed to look up and study other learning resources available online. On the other hand, Self-Instruction may also refer to learners studying the modules on their own outside the school. This option is available for learners who exhibit functional literacy, and who are unable to regularly report to school due to valid reasons such as illness, or the need to assist parents at work.

\section{Modified In-School Off-School Approach (MISOSA)}

19. In order to address limitations in classrooms, teachers, and learning materials, DepEd schools may offer the Modified In-School Off-School Approach (MISOSA). This delivery mode specifically caters to Grades 4, 5, and 6 classes with at least 50 learners. Learners are divided into two groups. During class hours, except on designated days for assessments, only one of the groups will be in school, while the other will be at another location near the school or will meet online through a platform prepared by the school, depending on the agreement set by the class. The in-school group will proceed with formal instruction facilitated by their regular school teachers, while the out-school group will have independent learning using the materials provided by the school, with the assistance of a para-teacher or learning facilitator. The groups will switch arrangements periodically (e.g. a week, or a month), depending on the agreed time between the learners and the teacher. The two groups shall meet together for assessment and for enrichment.

20. Acknowledging that independent learning requires functional literacy, learners are first required to take the Informal Reading Inventory (IRI) test, as well 
as other school-based assessment tools, and pre-tests before the implementation of the program. Learners that are found to be incapable of independent learning will have to stay in the in-school group, until they gain the necessary competencies. Further, the school will conduct an orientation for parents and guardians of those who will take part in the off-school arrangements, so that they may be informed of the goals of the program, the class schedule and venues, and the expectations from the learners.

21. The MISOSA may be implemented for learners who are capable of independent learning, and learners in emergency situations given the availability of learning facilitators, and accessible learning resources, learning centers, or platforms/software for program implementation.

\section{Night High School ${ }^{1}$}

22. The Night High School program aims to provide opportunity to high school learners to finish basic education through evening classes. The program is intended for high school learners, of legal age, who are working.

23. Secondary schools implementing night high school should submit to the Schools Division Office a night class program to be completed in 4 to 5 years for Junior Night High School and 2 to $2 \frac{1}{2}$ years for Senior Night High School. Classes should begin not earlier than 4:30 in the afternoon and end not later than 9:30 in the evening, and may include the conduct of Saturday classes. The program allows for the Technology and Livelihood Education (TLE) competencies to be completed in the learner's workplace subject to proper supervision and evaluation by the TLE teacher and the partner-employer. All other program schemes must be approved by the Schools Division Office.

\section{E. Open High School ${ }^{2}$}

24. The Open High School Program (OHSP) is an alternative mode of delivering secondary education that puts a premium on independent, self-paced and flexible study to reach learners who are unable to start or complete secondary education due to limited time, geographical inaccessibility of schools, physical impairment, financial difficulties, and/or social or family problems.

25. The program is open to all high school learners who are abale to demonstrate their capacity for independent learning through to Independent Learning Readiness Test (ILRT) and Informal Reading Inventory (IRI). Qualified learners are expected to report to school on a weekly basis during the first semester and subsequently reduced to a monthly consultation during the second half of the school year depending on his readiness for independent learning. A teacher-adviser and subject teachers shall be assigned to a class in order to provide support to the learner. The program is to be delivered for 6 years for Junior High and additional 3 years for Senior High School.

26. Table 3.1 summarizes the five ADMs DepEd offers.

${ }^{1}$ DECS Order No. 88 s. 1997

${ }^{2}$ DO 46 s.2006 
Table 3.1: Summary of DepEd ADMs

\begin{tabular}{|c|c|c|}
\hline ADM & Description & Target Beneficiaries \\
\hline Home School & $\begin{array}{l}\text { Provides basic education to } \\
\text { learners in a home-based setting } \\
\text { with parents, guardians or } \\
\text { tutors as learning facilitators, } \\
\text { under supervision by DepEd } \\
\text { and designated licensed } \\
\text { teachers. }\end{array}$ & $\begin{array}{l}\text { Learners who are unable to } \\
\text { attend school but have } \\
\text { someone who is capable of } \\
\text { delivering instruction }\end{array}$ \\
\hline $\begin{array}{l}\text { IMPACT } \\
\text { (Instructional } \\
\text { Management by } \\
\text { Parents, } \\
\text { Community, and } \\
\text { Teachers) }\end{array}$ & $\begin{array}{l}\text { Provides basic education to learners } \\
\text { in school-based setting wherein } \\
\text { multi-grade learners are grouped } \\
\text { for learning facilitated by peers, } \\
\text { parents, or community members } \\
\text { under the guidance of an } \\
\text { instructional supervisor. It also } \\
\text { allows for independent learning. }\end{array}$ & $\begin{array}{l}\text { Learners in congested schools } \\
\text { where there are community- } \\
\text { based volunteers and teachers }\end{array}$ \\
\hline $\begin{array}{l}\text { Modified In-School } \\
\text { Off-School } \\
\text { Approach } \\
\text { (MISOSA) }\end{array}$ & $\begin{array}{l}\text { Provision of formal education in } \\
\text { school and off-school to learners in } \\
\text { Grades } 4 \text { to } 6 \text { with capacity for } \\
\text { independent learning, and who } \\
\text { could not be fully accomodated in } \\
\text { school. They receive blended } \\
\text { instruction. In-school group are } \\
\text { with the classroom or subject } \\
\text { teachers and the off-school group } \\
\text { are with a teacher-facilitator in a } \\
\text { separate venue. }\end{array}$ & $\begin{array}{l}\text { 1. Learners in overpopulated } \\
\text { schools. } \\
\text { 2. Learners who are unable } \\
\text { to attend school regularly } \\
\text { due to economic, physical } \\
\text { and social constraints. }\end{array}$ \\
\hline Night High School & $\begin{array}{l}\text { Learners attend classes after } \\
\text { regular school hours. This learning } \\
\text { option allows program completion } \\
\text { beyond the prescribed number of } \\
\text { years. }\end{array}$ & $\begin{array}{l}\text { For high school learners who } \\
\text { are unable to go to school } \\
\text { during the day }\end{array}$ \\
\hline $\begin{array}{l}\text { Open High School } \\
\text { Program (OHSP) }\end{array}$ & $\begin{array}{l}\text { Provides opportunity to all high } \\
\text { school learners capable of } \\
\text { independent learning to complete } \\
\text { basic education through quality } \\
\text { distance education }\end{array}$ & $\begin{array}{l}\text { For high school learners who } \\
\text { are incapable of going or } \\
\text { staying in school }\end{array}$ \\
\hline
\end{tabular}

\section{ALS}

27. The Alternative Learning System (ALS) is distinguished from the ADMs by its use of the non-formal ALS - K to 12 Basic Education Curriculum. 
28. According to UNESCO, "the defining characteristic of non-formal education is that it is an addition, alternative and/or a complement to formal education in the process of the lifelong learning of individuals. It caters to people of all ages, but does not necessarily apply a continuous pathway-structure. Nonformal education can cover programs contributing to adult and youth literacy and education for out-of-school children, as well as programs on life skills, work skills, and social or cultural development."

29. The ALS-K to 12 Basic Education Curriculum is aligned with the $\mathrm{K}$ to 12 Enhanced Basic Education Curriculum. Like the $\mathrm{K}$ to 12 formal curriculum, the ALS-K to 12 Basic Education Curriculum (ALS-K to 12) is also expressed in Content Standards, Performance Standards and Learning Competencies. In addition, ALS learning competencies are also coded. Those that have been lifted from the formal curriculum have two codes, i.e. their code from the formal curriculum and their ALS learning competency code.

30. During the alignment and finalization process, many learning competencies from the formal school curriculum were adopted in the ALS-K to 12 Basic Education Curriculum. Additionally, some competencies on ICT and life skills that are not found in the formal school system have been included.

31. There was significant expansion of the content scope of the curriculum to ensure alignment with the formal $\mathrm{K}$ to 12 school curriculum. The number of competencies included in the former ALS curriculum was increased from 776 learning competencies to 2,046 enhanced learning competencies.

32. In general, the ALS-K to 12 is organized into six interrelated learning strands that bring functional literacy and content knowledge together. It has contextualized learning materials which take into account the prior learning, competencies, and experiences of learners. The strands continue to be anchored on the original learning strands of the ALS-K to 12 with some refinements:

a. Revision of the content scope and title of Learning Strand 3 to Life and Career Skills

b. Integration of the former Learning Strand 4 (Development of Self and Sense of Community) and Learning Strand 5 (Expanding One's World Vision) into a single learning strand (Learning Strand 4) titled "Development of Self and Sense of National, Regional, Global Identity"

c. Development of a new learning strand (competencies for Learning Strand 5) focused on digital literacy

d. Separation of the former Learning Strand 2 into two separate strands (Scientific Literacy and Critical Thinking Skills and Mathematical and Problem-Solving Skills)

33. Table 3.2 shows the six learning strands and corresponding topics or skills.

Table 3.2: ALS Curriculum Learning Strands

\begin{tabular}{|l|l|}
\hline \multicolumn{1}{|c|}{ Learning Strands } & \multicolumn{1}{c|}{ Topics or Skills } \\
\hline \multirow{2}{*}{ Learning Strand 1} & Communication Skills (English) \\
\cline { 2 - 3 } & Communication Skills (Filipino) \\
\hline Learning Strand 2 & Scientific Literacy and Critical Thinking Skills \\
\hline Learning Strand 3 & Mathematical and Problem-Solving Skills \\
\hline
\end{tabular}




\begin{tabular}{|l|l|}
\hline \multicolumn{1}{|c|}{ Learning Strands } & \multicolumn{1}{c|}{ Topics or Skills } \\
\hline Learning Strand 4 & Life and Career Skills \\
\hline Learning Strand 5 & Understanding the Self and Society \\
\hline Learning Strand 6 & Digital Literacy \\
\hline
\end{tabular}

34. Each strand has a schematic diagram that describes the relationship of the parts to the whole strand. Each strand contains content and performance standards which are then followed by learning competencies. Next to the learning competencies are columns representing the ALS learning stages, specifically: Basic Literacy, Elementary level (Lower and Advanced), Junior High School and Senior High School.

35. The table below (Table 3.3) summarizes the content per learning strand:

Table 3.3 ALS - K to 12 Basic Education Curriculum Learning Strands Content

\begin{tabular}{|c|c|}
\hline Learning Strand & Description \\
\hline $\begin{array}{l}\text { Learning Strand 1: } \\
\text { Communication } \\
\text { Skills (English) }\end{array}$ & $\begin{array}{l}\text { The main thrust of Learning Strand (LS) 1: Communication } \\
\text { Skills is to develop the ability to access, critically process and } \\
\text { effectively use available information in a variety of media to } \\
\text { be able to: } \\
\text { 1. function effectively as a member of the family, } \\
\text { community, nation, and the world; and } \\
\text { 2. participate actively in community and economic } \\
\text { development. } \\
\text { Learning Strand } 1 \text { involves the five macro skills: (1) listening } \\
\text { purposively and critically; (2) speaking clearly and } \\
\text { appropriately; (3) reading to process and critically use } \\
\text { information from a wide range of written materials and other } \\
\text { forms of media; (4) expressing one's ideas and feelings clearly } \\
\text { and effectively in writing; and (5) viewing as an ability to } \\
\text { demonstrate critical understanding and interpretation of } \\
\text { visual media. } \\
\text { To complete SHS and meet the competencies for the middle } \\
\text { skills development, entrepreneurship, and employment exits } \\
\text { of the basic education curriculum, ALS learners must } \\
\text { complete the competencies that are specified in English for } \\
\text { Academic and Professional Purposes and Practical Research } \\
1 \text { and } 2 \text { (which are applied subjects). The topic of Practical } \\
\text { Research } 1 \text { and } 2 \text { may be lifted from the other ALS learning } \\
\text { strands. They should also complete the specialization } \\
\text { subjects of any of the following Senior High School } \\
\text { tracks: Sports, Arts and Design or Technical-Vocational- } \\
\text { Livelihood. } \\
\text { College-bound ALS learners in SHS must also complete the } \\
\text { core subjects Oral Communication, Reading and Writing and } \\
21 \text { st Century Literature from the Philippines and the World } \\
\text { (or their equivalents). They must also complete all the } \\
\text { specialization subjects in any of the Academic Strands } \\
\text { (Accountancy, Business and Management [ABM], Humanities }\end{array}$ \\
\hline
\end{tabular}




\begin{tabular}{|c|c|}
\hline Learning Strand & Description \\
\hline & $\begin{array}{l}\text { and Social Sciences [HUMSS], Science, Technology, } \\
\text { Engineering and Mathematics [STEM], or General Academic). }\end{array}$ \\
\hline $\begin{array}{l}\text { Learning Strand 1: } \\
\text { Communication } \\
\text { Skills (Filipino) } \\
\text { Kasanayan sa } \\
\text { Komunikasyong } \\
\text { Filipino }\end{array}$ & $\begin{array}{l}\text { Ang pangunahing layunin ay mapaunlad ang kakayahan ng } \\
\text { mga matatatanda at kabataang hindi na nakakapag-aral } \\
\text { upang kritikal na masuri, maabot at epektibong magamit ang } \\
\text { impormasyon sa pamamagitan ng iba't ibang uri ng midya } \\
\text { upang: } \\
\text { 1. Epektibong magampanan ang tungkulin bilang } \\
\text { miyembro ng pamilya, komunidad, bansa at daigdig; } \\
\text { 2. Aktibong makilahok sa pagpapaunlad ngkomunidad at } \\
\text { ekonomiya. } \\
\text { Kasangkot din dito ang limang makrong kasanayan: (1) } \\
\text { kritikal at malayuning pakikinig; (2) wasto, angkopat malinaw } \\
\text { na pagsasalita; (3) pagpoproseso mula sa pagbabasa at } \\
\text { masusing paggamit ng impormasyong nakasulat o inihayag } \\
\text { gamit ang iba't ibang anyo ng midya; (4) pagpapahayag ng } \\
\text { naiisip at nararamdaman nang malinaw at epektibo sa } \\
\text { pamamagitan ng pagsusulat; at (5) kritikal na pag-unawa at } \\
\text { pagpapakahulugan sa panonood mga midyang biswal. } \\
\text { Upang makapagtapos ng SHS at maging kuwalipikado para } \\
\text { sa trabaho, negosyo, at paglilinang ng 'middle skills', } \\
\text { kinakailangang makumpleto ng mag-aaral ng ALS ang } \\
\text { mga kompetensing nakasaad sa Filipino sa Piling Larangan } \\
\text { (na isang applied subject). Kinakailangan rin nilang } \\
\text { makumpleto ang mga specialization subjects sa isa sa mga } \\
\text { tracks na ito: Sports, Arts and Designo Technical-Vocational- } \\
\text { Livelihood. } \\
\text { Sa mga mag-aaral ng ALs na nais pumasok sa kolehiyo, } \\
\text { kinakailangan rin nilang kumpletuhin ang core subjects na } \\
\text { Komunikasyon at Pananaliksik sa Wika at Kulturang Filipino, } \\
\text { Pagbasa at Pagsusuri ng Iba't-ibang Teksto Tungo sa } \\
\text { nilang makumpleto ang mga specialization subjects sa isa sa } \\
\text { mga strand ng Academic Track (Accountancy, Business and } \\
\text { Management [ABM], Humanities and Social Sciences } \\
\text { [HUMSS], Science, Technology, Engineering and } \\
\text { Mathematics [STEM], at General Academic). }\end{array}$ \\
\hline
\end{tabular}




\begin{tabular}{|c|c|}
\hline Learning Strand & Description \\
\hline $\begin{array}{l}\text { Learning Strand 2: } \\
\text { Scientific Literacy } \\
\text { and Critical } \\
\text { Thinking }\end{array}$ & \multirow{4}{*}{$\begin{array}{l}\text { Learning Strands } 2 \text { and } 3 \text { are intended to develop skills which } \\
\text { include the core competencies of scientific literacy and } \\
\text { numeracy. Integrated across scientific and numeracy literacy } \\
\text { skills are the critical functional competencies of openness to } \\
\text { change, awareness of options, ability to make critical and } \\
\text { informed decisions, curiosity, innovativeness and creativity, } \\
\text { scientific thinking, logical reasoning, spatial intelligence and } \\
\text { future orientation. These competencies specifically seek to } \\
\text { extend and refine learners' critical and creative thinking } \\
\text { processes including the abilities to: } \\
\text { 1. Organize new knowledge; } \\
\text { 2. Gather and analyze information; } \\
\text { 3. Categorize things and ideas; } \\
\text { 4. Make comparisons; } \\
\text { 5. Infer principles from evidences; } \\
\text { 6. Critique one's own thinking; } \\
\text { 7. Evaluate options as a basis of decision making; } \\
\text { 8. Apply the scientific process; } \\
\text { 9. Seek explanation for applying the scientific process; } \\
\text { 10. Support assertions with evidences; } \\
\text { 11. Overcome obstacles and find a better way to do things; } \\
\text { 12. Apply principles to draw conclusions; and } \\
\text { 13. Learn independently. } \\
\text { The ultimate goal of Learning Strands } 2 \text { and } 3 \text { is to develop } \\
\text { individuals who are aware of their own thinking, able to make } \\
\text { critical and informed decisions, defend their ideas and } \\
\text { evaluate the ideas of others and are persistent in striving for } \\
\text { new ways of solving problems. Through the development of } \\
\text { such critical thinking and problem-solving skills, ALs } \\
\text { learners will enhance their own personal and social } \\
\text { effectiveness as a pathway to improve quality of life. }\end{array}$} \\
\hline & \\
\hline \multirow[t]{4}{*}{$\begin{array}{l}\text { Learning Strand 3: } \\
\text { Mathematical and } \\
\text { Problem-Solving } \\
\text { Skills }\end{array}$} & \\
\hline & \\
\hline & $\begin{array}{l}\text { Scientific Literacy and Critical Thinking skills } \\
\text { To complete SHS and meet the competencies for middle skills } \\
\text { development, entrepreneurship, and employment exits of the } \\
\text { basic education curriculum, ALS learners must complete the } \\
\text { competencies that are specified in Inquiries, Investigations } \\
\text { and Immersion (which is an applied subject). They should } \\
\text { also complete the specialization subjects of any of the } \\
\text { following Senior High School tracks: Sports, Arts and Design } \\
\text { or Technical-Vocational-Livelihood. }\end{array}$ \\
\hline & $\begin{array}{l}\text { College-bound ALS learners in SHS must also complete the } \\
\text { core subjects Earth and Life Science, Physical Science, } \\
\text { Physical Education and Health and Disaster Readiness and } \\
\text { Risk Reduction (or their equivalents). They must also } \\
\text { complete all the specialization subjects in any of the } \\
\text { Academic Strands (Accountancy, Business and Management }\end{array}$ \\
\hline
\end{tabular}




\begin{tabular}{|c|c|}
\hline Learning Strand & Description \\
\hline & $\begin{array}{l}\text { [ABM], Humanities and Social Sciences [HUMSS], Science, } \\
\text { Technology, Engineering and Mathematics [STEM], or } \\
\text { General Academic). } \\
\text { Mathematical and Problem Solving Skills } \\
\text { To complete SHS and meet the competencies for middle skills } \\
\text { development, entrepreneurship, and employment exits of the } \\
\text { basic education curriculum, ALS learners must complete the } \\
\text { competencies that are specified in Statistics and Probability. } \\
\text { They should also complete the specialization subjects of any } \\
\text { of the following Senior High School tracks: Sports, Arts and } \\
\text { Design or Technical-Vocational-Livelihood. } \\
\text { College-bound ALS learners in SHS must also complete the } \\
\text { core subjects General Mathematics and Statistics and } \\
\text { Probability (or their equivalents). They must also complete all } \\
\text { the specialization subjects in any of the Academic Strands } \\
\text { (Accountancy, Business and Management [ABM], Humanities } \\
\text { and Social Sciences [HUMSS], Science, Technology, } \\
\text { Engineering and Mathematics [STEM], or General Academic). }\end{array}$ \\
\hline $\begin{array}{l}\text { Learning Strand } 4 \text { : } \\
\text { Life and Career } \\
\text { Skills }\end{array}$ & $\begin{array}{l}\text { Learning Strand } 4 \text { focuses on the attitudes, skills, and } \\
\text { knowledge (competencies) necessary for earning a living and } \\
\text { promoting a sustainable lifestyle. } \\
\text { This learning strand covers the ability to earn a living - } \\
\text { through employment/self-employment, entrepreneurship, } \\
\text { sustainable consumption - live within one's means, navigate } \\
\text { the market place (as both consumer and seller), reduce } \\
\text { wasteful expenditure and perform wise } \\
\text { consumption/utilization of resources; conserve resources for } \\
\text { future generations; and produce and use work-related skills, } \\
\text { knowledge, values and technology to maximize one's } \\
\text { efficiency and performance as a productive citizen. } \\
\text { In addition to demonstrating mastery of skills completed } \\
\text { under LS } 4 \text { all ALS learners are encouraged to complete at } \\
\text { least one TVL track specialization leading to the acquisition } \\
\text { of occupational skills and a national certificate (NC). } \\
\text { Learners are referred to the list of specializations in formal } \\
\text { school's TVL Track. } \\
\text { To complete SHS and meet the competencies for the middle } \\
\text { skills development, entrepreneurship, and employment exits } \\
\text { of the basic education curriculum, ALS learners must } \\
\text { complete the competencies that are specified in } \\
\text { Entrepreneurship (which is an applied subject). They should } \\
\text { also complete the specialization subjects of any of the }\end{array}$ \\
\hline
\end{tabular}




\begin{tabular}{|c|c|}
\hline Learning Strand & Description \\
\hline & $\begin{array}{l}\text { following Senior High School tracks: Sports, Arts and Design } \\
\text { or Technical-Vocational-Livelihood. } \\
\text { College-bound ALS learners in SHS must also complete the } \\
\text { core subject Personal Development (or its equivalent). They } \\
\text { must also complete all the specialization subjects in any of } \\
\text { the Academic Strands (Accountancy, Business and } \\
\text { Management [ABM], Humanities and Social Sciences } \\
\text { [HUMSS], Science, Technology, Engineering and } \\
\text { Mathematics [STEM], or General Academic). }\end{array}$ \\
\hline $\begin{array}{l}\text { Learning Strand 5: } \\
\text { Understanding Self } \\
\text { and Society }\end{array}$ & $\begin{array}{l}\text { Learning Strand } 5 \text { is intended to help learners acquire a } \\
\text { positive sense of self and social responsibility that will lead } \\
\text { them to develop their potentials and enable them to live } \\
\text { together harmoniously within the contexts of their family, } \\
\text { local community, and country as well as participate as a } \\
\text { member of the ASEAN region and an increasingly global } \\
\text { community. } \\
\text { This means helping learners develop the capacity to think } \\
\text { with complexity and take into account multiple cultural } \\
\text { perspectives. (Source: Chickering and Reisser 1993). In an } \\
\text { increasingly globalized world, it is important that learners are } \\
\text { able to see things through the hearts, minds and eyes of } \\
\text { others and understand the impact of regional and global } \\
\text { issues on their lives and the lives of the members of their } \\
\text { family, community and country. } \\
\text { The learning strand endeavors to encourage learners to } \\
\text { continue developing the knowledge, attitudes, values and } \\
\text { skills in order to act locally in building a just, peaceful, } \\
\text { equitable, compassionate, multi-cultural and pluralistic } \\
\text { society. Hence, it is important to articulate in the minds of } \\
\text { the learners that whatever they do affects their sphere of } \\
\text { influence (family and community) and creates an impact on } \\
\text { the nation, the region and the world. According to Colby and } \\
\text { Sullivan (2009) persons with a civic and moral identity and } \\
\text { sense of obligation to society are more apt to behave in ways } \\
\text { that fulfill individual and social responsible goals. Thus, as } \\
\text { members of the ASEAN and world communities, learners' } \\
\text { horizons for developing identity need to be national, regional } \\
\text { and global. } \\
\text { To complete SHS and meet the competencies for the middle } \\
\text { skills development, entrepreneurship, and employment exits } \\
\text { of the basic education curriculum, ALS learners must } \\
\text { complete the competencies that are specified in Disciplines } \\
\text { and Ideas in the Applied Social Sciences (which is a } \\
\text { Humanities and Social Sciences Strand subject). They } \\
\text { should also complete the specialization subjects of any of the }\end{array}$ \\
\hline
\end{tabular}




\begin{tabular}{|c|c|}
\hline Learming Strand & Description \\
\hline & $\begin{array}{l}\text { following Senior High School tracks: Sports, Arts and Design } \\
\text { or Technical-Vocational-Livelihood. } \\
\text { College-bound ALS learners in SHS must also complete the } \\
\text { core subjects Contemporary Philippine Arts from the Regions, } \\
\text { Introduction to Philosophy of the Human Person, and } \\
\text { Understanding Culture, Society and Politics (or their } \\
\text { equivalents). They must also complete all the specialization } \\
\text { subjects in any of the Academic Strands (Accountancy, } \\
\text { Business and Management [ABM], Humanities and Social } \\
\text { Sciences [HUMSS], Science, Technology, Engineering and } \\
\text { Mathematics [STEM], or General Academic). }\end{array}$ \\
\hline $\begin{array}{l}\text { Learning Strand 6: } \\
\text { Digital Literacy }\end{array}$ & $\begin{array}{l}\text { This learning strand seeks to help equip ALS learners with } \\
\text { critical knowledge, skills and values to be able to live and } \\
\text { work effectively as part of the digital universe. } \\
\text { To achieve digital literacy, ALS learners need both ICT-related } \\
\text { knowledge and skills and the ability to integrate such skills } \\
\text { and knowledge across the competencies listed in the other } \\
\text { four learning strands of the ALS curriculum. This is the } \\
\text { application part where the learners use their digital } \\
\text { knowledge and skills as tools to communicate with others and } \\
\text { solve problems in daily life. Each of the other four learning } \\
\text { strands will thus go hand in hand with Learning Strand } 6 \text {. } \\
\text { This Learning Strand covers the following digital literacy } \\
\text { competencies: } \\
\text { 1. Digital Concepts } \\
2 \text {. Digital Operations and Management } \\
\text { 3. Digital Applications } \\
4 \text {. Digital Systems Network } \\
5 \text {. Digital Devices } \\
6 \text {. Digital Ethics } \\
\text { To complete SHS and meet the competencies for the middle } \\
\text { skills development, entrepreneurship, and employment exits } \\
\text { of the basic education curriculum, ALS learners must } \\
\text { complete the competencies that are specified Empowerment } \\
\text { Technologies (which is an applied subject). They should also } \\
\text { complete the specialization subjects of any of the following } \\
\text { Senior High School tracks: Sports, Arts and Design or } \\
\text { Technical-Vocational-Livelihood. } \\
\text { College-bound ALS learners in SHS must also complete the } \\
\text { core subject Media and Information Literacy (or its } \\
\text { equivalent). They must also complete all the specialization } \\
\text { subjects in any of the Academic Strands (Accountancy, } \\
\text { Business and Management [ABM], Humanities and Social } \\
\text { Sciences [HUMSS], Science, Technology, Engineering and } \\
\text { Mathematics [STEM], or General Academic). }\end{array}$ \\
\hline
\end{tabular}


36. The levels of difficulty have also been aligned with the grade levels of the formal school system. This is shown in the table below:

Table 3.4: Alignment of the ALS-K to 12 Levels and the $K$ to 12 Basic ducation Curriculum Grade Levels

\begin{tabular}{|l|l|}
\hline \multicolumn{1}{|c|}{ ALS-K to 12 Levels } & K to $\begin{array}{c}12 \text { Basic Education Curriculum } \\
\text { Grade Levels }\end{array}$ \\
\hline Elementary Level & Kindergarten to Grade 1 \\
\hline Basic Literacy & Grades 2 to 3 \\
\hline Lower Elementary & Grades 4 to 6 \\
\hline Advanced Elementary & \\
\hline Secondary Level & Grades 7 to 10 \\
\hline Junior High School (JHS) & Grades 11 to 12 \\
\hline Senior High School (SHS) &
\end{tabular}

37. In terms of program, ALS will be offered as basic literacy program, or continuing education assessment and equivalency program.

38. For the basic literacy program, the $\mathrm{K}$ to 12 Basic Education Curriculum for the Alternative Learning System (ALS-K to 12) Basic Literacy (BL) Competencies focus only on communication skills (listening, speaking, viewing, reading and writing) and numeracy. BL is equivalent to Kindergarten to Grade 1 in formal school.

39. The leveling of the Basic Literacy competencies was revised to focus on core competencies related to literacy macro skills (reading, writing, listening, speaking and viewing) and numeracy. At the point of curriculum implementation, competencies from the other learning strands will be used as the functional contexts for teaching these core macro skills.

40. Specific concepts/topics from other Learning Strands will be used as functional contents for the development of Basic Literacy (BL) skills.

41. For the Accreditation and Equivalency (A\&E) program, the competencies are grouped by learning strand and tagged by level of difficulty as shown in Table 3.4. 


\section{References}

Chickering, A. W., \& Reisser, L. (1993). Education and identity. San Francisco: Jossey-Bass Publishers.

Colby, A. and Sullivan, W.M. (2009) Strengthening the Foundations of Students' Excellence, Integrity, and Social Contribution. Liberal Education, 95(1), Association of American Colleges and Universities.

DECS Order No. 88 s. 1997 Implementing Guidelines for the Operation of High School Evening Classes

DECS Memo 216, s. 1997 Home Education Program

Deped Order 46 s.2006 Guidelines on the Pilot Implementation of the Open High School Program

DepEd Memo 243, s. 2008 Adoption of Implementation of the Project Instructional Management by Parents, Community, and Teachers (IMPACT)

SEAMEO INNOTECH. (2013). Enhanced Instructional Management for Parents, Community and Teachers (e-IMPACT) Guidebook. Quezon City: SEAMEO INNOTECH

UNICEF. (2012). UNICEF Evaluation on Alternative Delivery Modes: MISOSA and e-IMPACT Final Report. (2012). Retrieved on 5 January 2019 from https: / / ww uniceforg/evaldatabase/files/Philippines ADM Eval uation Philippines-2012-001.pdf 


\section{ANNEX 4: GUIDELINES ON MOTHER TONGUE-BASED MULTILINGUAL EDUCATION (MTB-MLE) PROGRAM IMPLEMENTATION}

\section{Rationale}

1. Section 10.2 of Republic Act No. 10533 or the Enhanced Basic Education Act of 2013 mandates that the basic education curriculum shall:

a. Be learner-centered, inclusive, and developmentally appropriate;

b. Be relevant, responsive, and research-based;

c. Be gender and culture-sensitive;

d. Be contextualized and global;

e. Use pedagogical approaches that are constructivist, inquiry-based, reflective, collaborative, and integrative;

f. Adhere to the principles and framework of Mother Tongue-Based Multilingual Education (MTB-MLE);

g. Use the spiral progression approach to ensure mastery of knowledge and skills after each level; and,

h. Be flexible enough to allow schools to localize, indigenize and enhance the same based on their respective educational and social contexts.

2. In Mother Tongue-Based Multilingual Education (MTB-MLE), the learner's Mother Tongue (MT) serves as the fundamental language for literacy and learning, and is used as the medium of teaching and learning (MOTL). According to Ocampo, et al. (2006), "The use of the mother tongue in learning has been found to be the most effective way to bridge learning in all subject areas including the development of future languages. This is a generalization based on numerous experiences of other multilingual countries as well as empirical studies conducted in the Philippines (p. v)." Furthermore, MTB-MLE leads to much less repetition, lower drop-out rates and higher educational attainment. (Ocampo et al., 2006; Smits, et al., 2008)

3. According to a 2014 study conducted by the Education Sector Analytical and Capacity Development Partnership (ACDP), together with the Asian Development Bank (ADB), Australian Aid, and the European Union, access to an MTB-MLE program enables children to "develop better language skills in their mother tongues as well as national languages. When knowledge of a second language (L2) is added to a rich knowledge of a first language (L1), a child forms complex knowledge networks (additive bilingualism)".

4. The MTB- MLE Program started in 2009. After years of implementation, the Department of Education has achieved substantial gains and milestones in the implementation of MTB-MLE especially in the improvement of literacy and numeracy skills (2015 LAPG data), decrease in school leavers in the early grades (BEIS data 2005-2014), and development and language contextualization of teaching and learning materials (Metila, 2016). 
5. These guidelines seek to sustain these gains and milestones by providing comprehensive guidance for MTB-MLE implementation based on promising practices developed over the years and by introducing refinements from lessons learned.

6. These guidelines also seek to provide guidance on the materials development and contextualization process as applied to MTB-MLE implementation as mandated by the Implementing Rules and Regulations of the Enhanced Basic Education Act of 2013. Section 10.3 of the said IRR states that, "The production and development of locally produced teaching and learning materials shall be encouraged. The approval of these materials shall be devolved to the regional and division education unit in accordance with national policies and standards."

\section{Scope of the Policy}

7. This DepEd Order establishes the guidelines for strengthening the implementation of the MTB-MLE program including the processes, standards, and tools for contextualization of teaching and learning materials in the MT.

\section{Definition of Terms}

8. For the purposes of this Order, the following terms are defined and understood, as follows:

a. Bridging refers to an instructional strategy that builds on what learners already know about their MT to develop their proficiency in other languages.

b. Contextualization refers to the educational process of relating the curriculum and/or teaching and learning materials to a particular setting, situation or area of application to make the competencies relevant, meaningful, and useful to all learners.

As defined in DepEd Order (DO) No. 32, s. 2015, the degree of contextualization may be distinguished into the following interrelated educational processes:

i. Localization refers to the process of relating learning content specified in the curriculum to local information and materials in the learner's community.

ii. Indigenization refers to the process of enhancing the curriculum competencies, education resources, and teaching-learning processes in relation to the bio-geographical, historical, and sociocultural context of the learner's community. Indigenization may also involve the enhancement of curriculum framework, curriculum design, and learning standards of subject areas, 
guided by the standards and principles adhered to in the national curriculum.

c. Development refers to the creation and production of new teaching learning resources.

d. Developmentally appropriate materials refer to a quality of teaching and learning materials that takes into account the age and the individual needs of the learner. This would mean a material that meets the cognitive, emotional, physical and cultural needs of children based on child development theories and children's individual strengths and weaknesses.

e. Learning Resource Development refers to the process of developing and/or contextualizing, testing, and revising learning resources that help the learners to develop literacy skills in the MT and concepts in other learning areas.

f. Learning Resources refer to teaching and learning materials

g. Lingua Franca refers to the language most commonly used in the community. This may also refer to the regional language, or the language that is familiar to a large number of people in the community.

h. Medium of Teaching and Learning (MOTL) refers to the Language of Instruction (LOI) or Medium of Instruction (MOI).

i. Mother Tongue (MT) refers to the "language or languages first learned by a child, which he or she identifies with, is identified as a native language user of by others, which he or she knows best, or uses habitually" (Section 4(d), Implementing Rules and Regulations of RA 10533).

j. Mother Tongue-Based Multilingual Education (MTB-MLE) refers to the effective use of more than two languages in the teaching and learning process, starting from the language that the learner is more familiar with before introducing other languages.

k. Orthography refers to the conventions of spelling and rules of written language as agreed upon by the users of that language.

1. Protocol refers to a document that details the mechanisms, procedures and rules to be adhered to by parties in relation to an issue or concern, or an agreed upon objective.

m. Standard refers to an established norm or requirement. Standards are developed or formulated by professional groups, associations, unions, 
guilds and communities who have a stake in the product or service being evaluated.

n. Teaching Beginning Reading refers to the teaching process to achieve child's fluency. The use of mother tongue is the most effective medium in teaching beginning reading wherein all materials should be contextualized.

\section{Policy Statement}

9. The Department hereby establishes the guidelines to inform policymaking, planning and programming for the proper implementation of the MTB-MLE Program which includes policies on: the learner's mother tongue; the MOTL for the various learning domains and learning areas of $\mathrm{K}$ to 3 , and, the bridging/ transition from the mother tongue to other languages. This is followed by statement and thorough explanation of each of the program components, namely:
a. National curriculum that can be contextualized;
b. Contextualization of curriculum and learning materials;
c. Development of resources for contextualization
d. Revisiting/ developing writing systems;
e. Assessment;
f. Training of teachers and instructional support; and
g. Community engagement and support.

\section{Essential Components of MTB-MLE Program}

\section{A. MTB-MLE Curriculum}

10. MTB-MLE Curriculum is a national curriculum that can be contextualized according to the structure and orthography of the Mother Tongue (MT).

11. Currently, there are nineteen (19) languages that are being used as MOTL and as learning areas:
a. Akeanon/Akianon
b. Bikol
c. Chavacano
d. Hiligaynon
e. Ilokano/Iloko
f. Ivatan
g. Kapampangan
h. Kinaray-a
i. Maguindanaon
j. Maranao 
k. Pangasinan/Pangasinense

1. Sambal

m. Sinugbuanong Binisaya/Cebuano

n. Sunurigaonon/Surigaonon

o. Tagalog

p. Tausug

q. Waray

r. Yakan

s. Ybanag/Ibanag

12. MT as a learning area can only be found in the early grades curriculum (Kindergarten to Grade 3), and shall focus on developing language and literacy skills, such as: oral language development, phonological awareness, book and print orientation, alphabet knowledge, word recognition, fluency, spelling, handwriting, composing, grammar awareness, vocabulary, reading comprehension, attitude towards language, literature, literacy, and study skills.

13. For MT languages that are not included in the 19 languages currently used by the Department, the school may use the lingua franca that is closest to any of the 19 languages as a subject for literacy development and as medium of teaching and learning. Assistance from the parents/community volunteers who are native speakers is necessary to help learners bridge their MT to the lingua franca.

14. In situations where 1) the language of the learners and the lingua franca are totally different; 2) the language of the learners is not included in any of the 19 languages; and 3) the community where the learners belong has developed its own working orthography, writing system, grammar and spelling rules and other learning materials, the school may use the language as a subject for literacy development and as MOTL.

15. MT shall be strictly used as the sole MOTL in all domains of Kindergarten and for all learning areas of Grades 1 to 3 except for Filipino and English. However, the MT may be used for transition or bridging and/or as an auxiliary MOTL up to Grade 6 as necessary.

\section{Mother Tongue Curriculum Contextualization}

16. Recognizing that language and culture are interrelated, the contextualization process must consider and incorporate local culture which encompasses technologies, practices, beliefs, arts, and traditions in the curriculum, among others. In cases involving IP languages, please refer to DO No. 32, s. 2015 for contextualization guidelines.

17. SDOs and ROs may refer to the Annex of DO No. 32, s. 2015 for examples of contextualizing the curriculum. 


\section{B. Learning Resources}

\section{Learning Resource Development}

18. Once the MTB-MLE curriculum has been contextualized according to the local language system, ROs and SDOs should ensure that appropriate materials are available at the school level in order to ensure quality implementation of the program.

19. The development of learning resources and instructional materials shall be incentivized (i.e. points for teacher promotion) at the schools division and regional levels to encourage the production of quality contextualized teaching and learning materials (TLMs).

20. For instances where materials have to be developed and/or contextualized to suit the needs of a particular language group or community, the processes outlined in Figure 4.1 shall be followed. It also contains the timeline and the offices responsible for each process. Table 4.1 details the Processes, Standards, and Tools for Mother Tongue Teaching and Learning Materials. Table 4.2 indicates the roles and functions of the person/s and institution/s involved in the processes.

21. RO, SDO, and the schools should continuously develop learning resources to support the implementation of MTB-MLE.

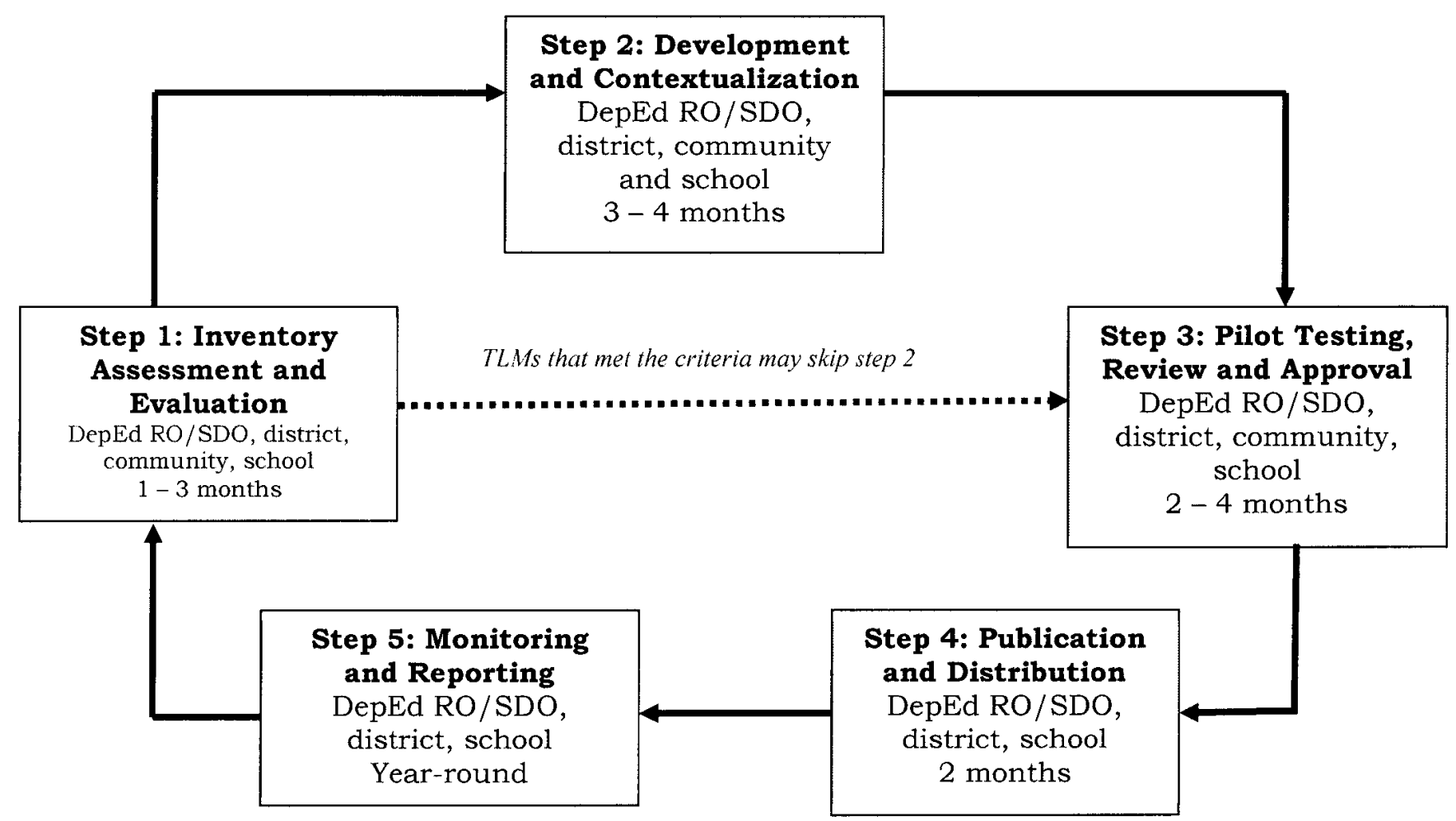

Figure 4.1. Process of Development and Contextualization of Teaching and Learning Materials 
Table 4.1. Processes, Standards, and Tools for Mother Tongue Teaching and Learning Materials

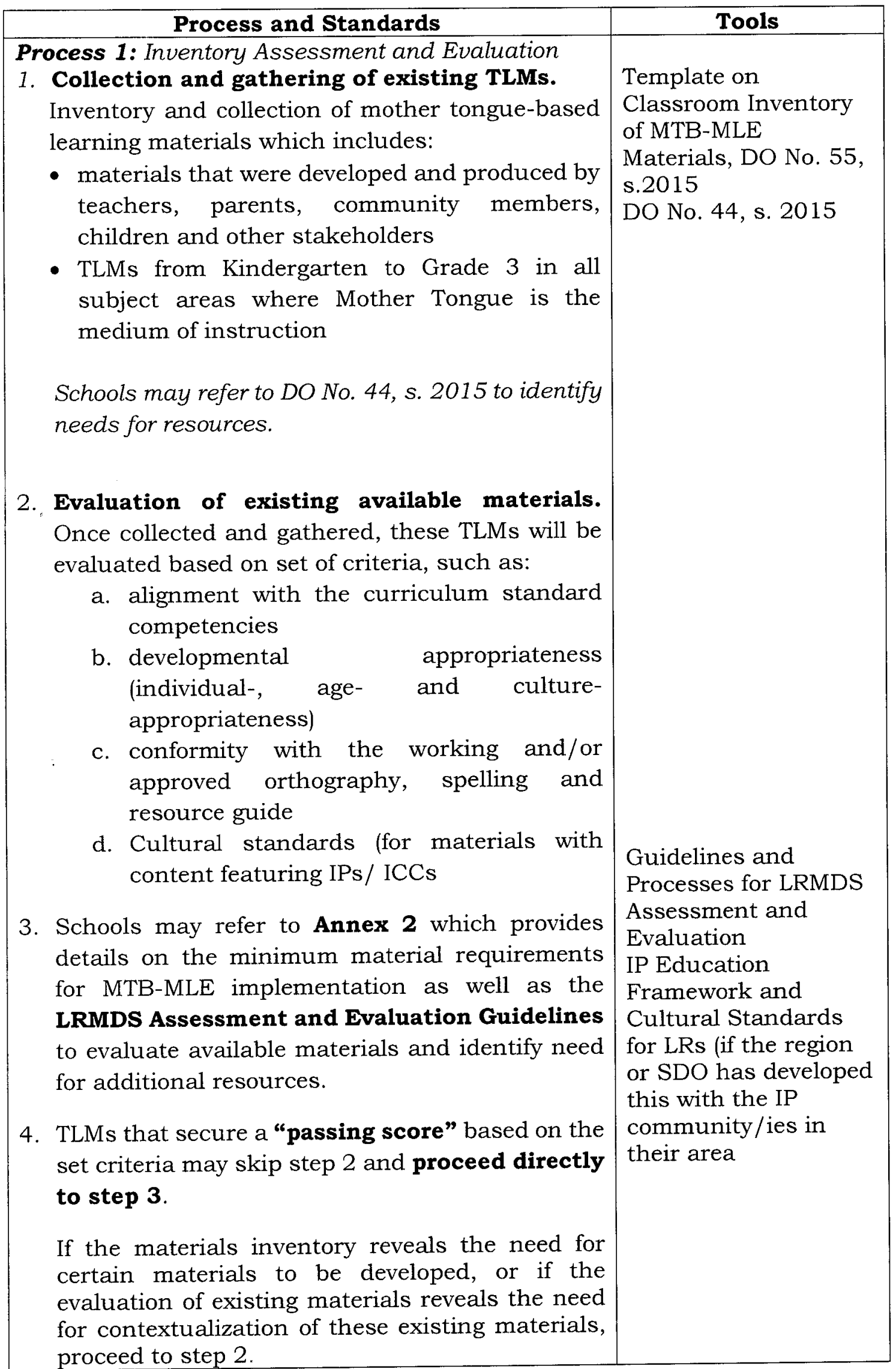


Process 2: Development and Contextualization

1. Establishment of partnerships with the community and local organizations of writers/ illustrators, non-government organizations, private companies and other community stakeholders to mobilize resources (technical, financial, and/or human resources) shall be encouraged. A stakeholder mapping and analysis maybe conducted to identify potential partners and formalize partnerships for implementation of teaching and learning materials development

2. Conduct of TLMs development and/or contextualization workshops.

A materials development workshop shall be conducted with representation and involvement of the following:

- the Language and Materials Development Team (LMDT)

- local writers,

- illustrators,

- culture bearers,

- community members

- and others who possess the required knowledge and skills on local language and culture.

The materials development workshops should:

a. Have clear design, process and specific outputs towards the end of the workshop

b. Have resource speakers that are experts in

the field, both language and content expertise c. Have mix of participants, both from private and public institutions and involvement of community members that meet the following criteria:

- proficiency in the target language;

- familiarity with the local culture; and

- ability to write and/or illustrate stories for children

3. Development of learning resources should follow the existing DepEd standard and criteria for development/writing of TLMs. (i.e. big books, small books, etc.) Cultural standards set by the community shall also used in this process.

Evaluation tool for supplementary reading materials Cultural standards for Learning Materials (if the region or SDO has developed this with the IP community/ies in their area) 


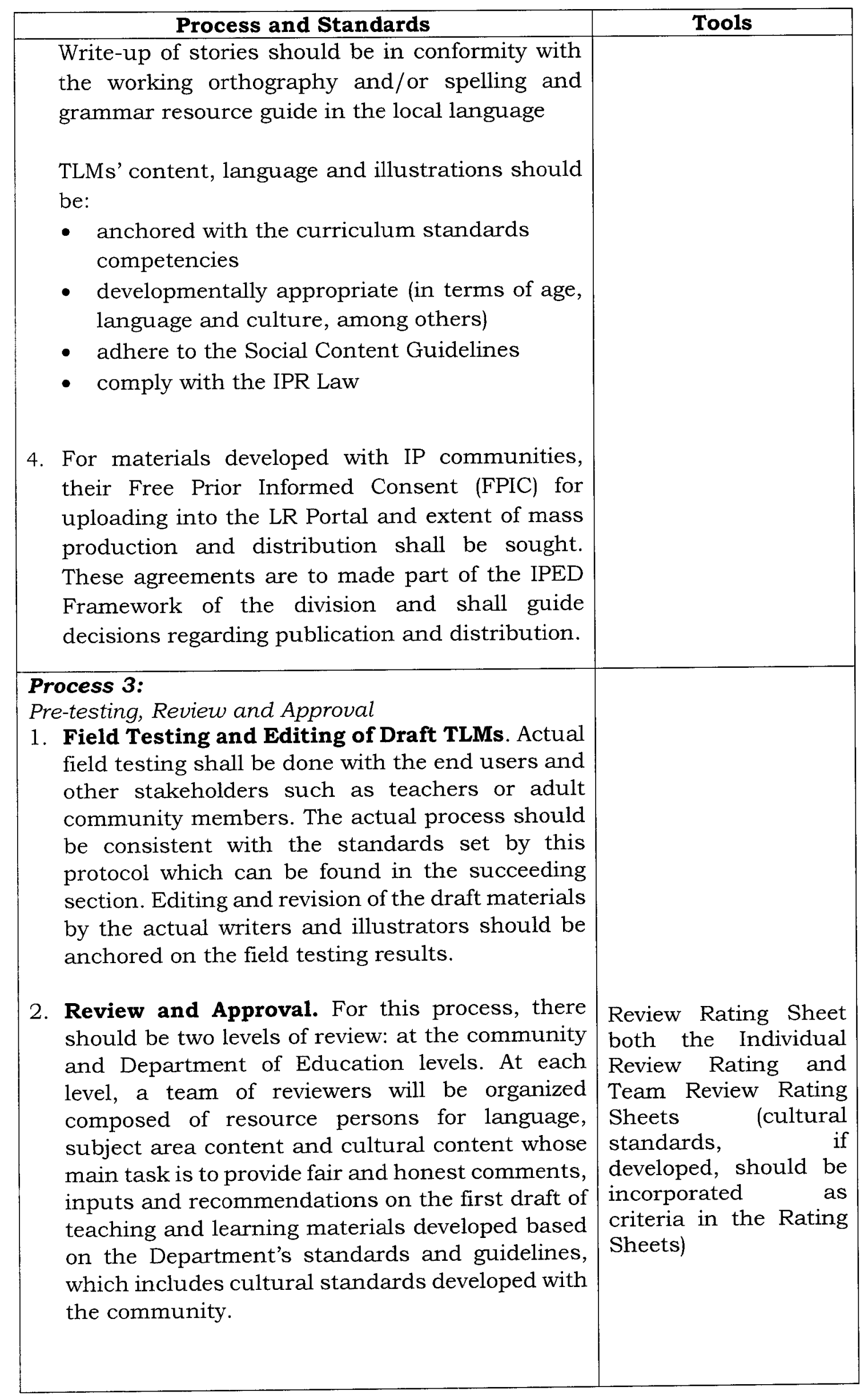




\begin{tabular}{|c|c|}
\hline $\begin{array}{l}\text { Process and Standards } \\
\end{array}$ & Tools \\
\hline $\begin{array}{l}\text { A revised draft shall be prepared by the actual } \\
\text { writers and illustrators which shall be submitted } \\
\text { to the Department of Education at the } \\
\text { regional/division level for final review and } \\
\text { approval. A specialty clearance will be released by } \\
\text { the Department to ensure that the TLM went } \\
\text { through the quality assurance process. Review } \\
\text { and approval shall be based on the } 2011 \\
\text { Guidelines on Instructional Materials } \\
\text { Development as provided by the Bureau of } \\
\text { Learning Resources } \\
\text { 3. In the case of Indigenous People language } \\
\text { communities, a final validation and } \\
\text { consultation process shall be conducted to } \\
\text { secure approval consistent with the FPIC. This } \\
\text { will also serve as basis for the Department in the } \\
\text { issuance of specialty clearance. }\end{array}$ & \\
\hline $\begin{array}{l}\text { Process 4: Publication and Distribution } \\
\text { 1. Publication. Upon approval of the final version of } \\
\text { the TLM/s, schools, division and region may } \\
\text { proceed with the printing and publication. } \\
\text { 2. Sources of funding for printing, publication and } \\
\text { distribution of teaching learning materials can be } \\
\text { sourced out from school's MOOE as stipulated in } \\
\text { DepEd Order No. 74, s. } 2009 \text { for MT materials or } \\
\text { may be drawn from local government unit's } \\
\text { (LGUs) Special Education Fund (SEF) and others. } \\
\text { Uploading to Learning Resource (LR) Portal. } \\
\text { The final and approved TLM/s will be translated } \\
\text { into a camera-ready file and submitted to the RO } \\
\text { LR Management Division and SDO LR Portal } \\
\text { Management Section for uploading and wider } \\
\text { sharing. Submit the inventory (grade level, } \\
\text { subject, title) of approved and uploaded LR to the } \\
\text { BLR Central Office. }\end{array}$ & \\
\hline $\begin{array}{l}\text { Process 5: Monitoring and Reporting } \\
\text { The Department at the regional and schools division } \\
\text { levels shall ensure that the teaching and learning } \\
\text { materials are utilized. Monitoring the effectiveness } \\
\text { will form part of the existing monitoring and } \\
\text { evaluation mechanisms at the school level, such as: }\end{array}$ & \\
\hline
\end{tabular}




\begin{tabular}{|c|c|}
\hline Process and Standards & Tools \\
\hline $\begin{array}{l}\text { - Record of TLMs used in classroom activities } \\
\text { and lessons will form part of teacher's daily } \\
\text { lesson log } \\
\text { - Incorporate effectiveness on the use of TLMs } \\
\text { through classroom observations during the } \\
\text { quarterly monitoring team supervision and } \\
\text { area monitoring visits } \\
\text { - Teachers to provide feedback after with the } \\
\text { school head and district supervisor } \\
\text { Provide the District/Division REC information } \\
\text { containing feedback on utilization of the TLMs } \\
\text { and to demonstration of usage and } \\
\text { engagement rating of the material. }\end{array}$ & $\begin{array}{l}\text { Utilization Log/ } \\
\text { Inventory of teaching } \\
\text { learning materials } \\
\text { Feedback Journal } \\
\text { Situation, Task, } \\
\text { Action, Result (STAR) } \\
\text { observation notes } \\
\text { with Material } \\
\text { Usability/Engagement } \\
\text { Rating }\end{array}$ \\
\hline
\end{tabular}

Table 4.2. Roles and Functions of Persons and Institutions Involved

\begin{tabular}{|c|c|c|}
\hline Process & Person/s and Institution/s Involved & Roles and Functions \\
\hline \multirow{5}{*}{ 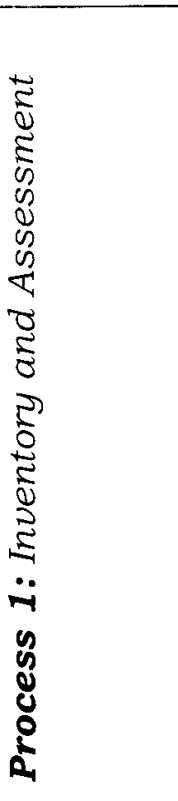 } & $\begin{array}{l}\text { Department of Education, Regional } \\
\text { and/or Schools Division levels: } \\
\text { - Regional Director and/or Schools } \\
\text { Division Superintendent }\end{array}$ & $\begin{array}{l}\text { Issues Memorandum for } \\
\text { inventory and assessment of } \\
\text { teaching and learning materials }\end{array}$ \\
\hline & $\begin{array}{l}\text { - Curriculum Implementation } \\
\text { Division, Chief/EPS in-charge of } \\
\text { MTB-MLE }\end{array}$ & $\begin{array}{l}\text { Lead oversight } \\
\text { management } \\
\text { implementation }\end{array}$ \\
\hline & - PSDS, school heads & Direct implementation \\
\hline & - Teachers, PTCA, parents, students & $\begin{array}{l}\text { Collection and submission of } \\
\text { copies of existing teaching and } \\
\text { learning materials }\end{array}$ \\
\hline & $\begin{array}{l}\text { - Special Team (reviewers, both } \\
\text { language and content) }\end{array}$ & $\begin{array}{l}\text { Evaluation of existing teaching } \\
\text { learning materials }\end{array}$ \\
\hline 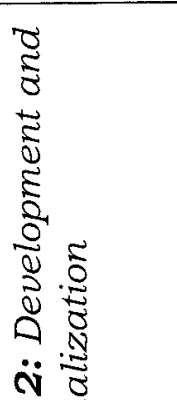 & $\begin{array}{l}\text { Department of Education, Regional } \\
\text { and/or Schools Division levels: } \\
\text { - Curriculum and Learning } \\
\text { Management Division (CLMD), } \\
\text { Curriculum Instruction Division } \\
\text { (CID), Chief/EPS in-charge of MTB- } \\
\text { MLE }\end{array}$ & 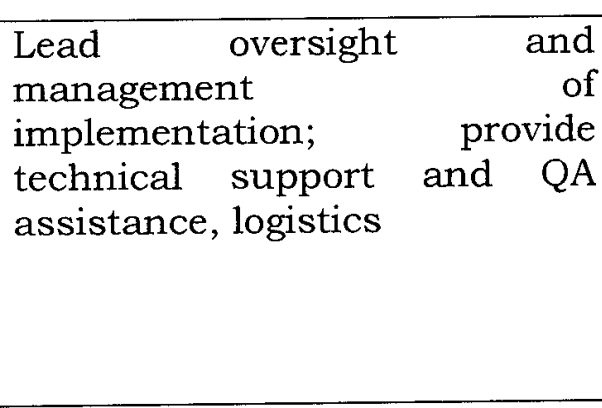 \\
\hline 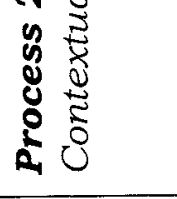 & $\begin{array}{l}\text { - Local government units and other } \\
\text { stakeholders (local organizations, } \\
\text { companies and other stakeholders) }\end{array}$ & Financial resources/funding \\
\hline
\end{tabular}




\begin{tabular}{|c|c|c|}
\hline Process & Person/s and Institution/s Involved & Roles and Functions \\
\hline & $\begin{array}{l}\text { - Non-government organizations, } \\
\text { academe, universities }\end{array}$ & Provide technical expertise \\
\hline & $\begin{array}{l}\text { - Teachers, parents, community } \\
\text { members, adults }\end{array}$ & Content writers and illustrators \\
\hline \multirow{5}{*}{ 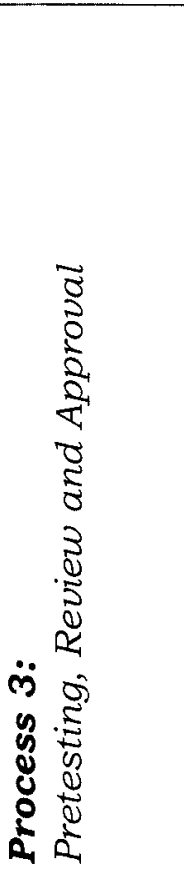 } & $\begin{array}{l}\text { Department of Education, Regional } \\
\text { and/or Division levels: } \\
\text { - CLMD, CID, Chief/EPS in-charge of } \\
\text { MTB-MLE }\end{array}$ & $\begin{array}{l}\text { Lead oversight and } \\
\text { management of field test and } \\
\text { review processes; provide } \\
\text { technical support; issuance of } \\
\text { specialty clearance }\end{array}$ \\
\hline & - School heads and teachers & $\begin{array}{l}\text { Setting the groundwork and } \\
\text { mobilization of participants for } \\
\text { the field test; }\end{array}$ \\
\hline & $\begin{array}{l}\text { - Teachers, parents, community } \\
\text { members, adults }\end{array}$ & Actual participants \\
\hline & $\begin{array}{l}\text { - IP community elders and leaders, } \\
\text { cultural experts }\end{array}$ & $\begin{array}{l}\text { Endorsement of teaching and } \\
\text { learning materials }\end{array}$ \\
\hline & - Language and content experts & $\begin{array}{l}\text { Evaluate the teaching and } \\
\text { learning materials and provide } \\
\text { recommendations } \\
\text { revisions / finalization for } \\
\text { defined in the contract }\end{array}$ \\
\hline \multirow{3}{*}{ 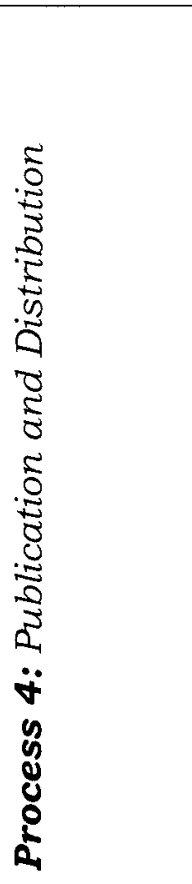 } & $\begin{array}{l}\text { - School Review and Evaluation } \\
\text { Committee (SREC) (School heads) } \\
\text { - District Review and Evaluation } \\
\text { Committee (DiREC) (PSDS, identified } \\
\text { members) } \\
\text { - Division Review and Evaluation } \\
\text { Committee (DREC) (EPS-LR, } \\
\text { Learning Area Supervisors) } \\
\text { - Regional Evaluation Team (RET) } \\
\text { (Chief, EPS-LR, identified members) }\end{array}$ & $\begin{array}{l}\text { Endorsement of teaching } \\
\text { learning materials for school, } \\
\text { district, division and/or } \\
\text { regional wide use }\end{array}$ \\
\hline & $\begin{array}{l}\text { - DREC/RET (EPS-LR, PDO, librarian, } \\
\text { Learning Manager and staff) }\end{array}$ & $\begin{array}{l}\text { Check endorsement and } \\
\text { certification for uploading of } \\
\text { TLMs to LRMDS portal }\end{array}$ \\
\hline & $\begin{array}{l}\text { - Finance Division of DepEd; local } \\
\text { government units }\end{array}$ & $\begin{array}{l}\text { Allocate local funds for } \\
\text { reproduction of TLMs }\end{array}$ \\
\hline \multirow{2}{*}{ 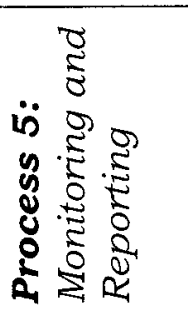 } & School heads & $\begin{array}{l}\text { Check lesson } \log \text { and list of } \\
\text { TLMs used; conduct of } \\
\text { classroom observations }\end{array}$ \\
\hline & PSDS/DREC/RET & $\begin{array}{l}\text { Check inventory reports and } \\
\text { conduct of quarterly } \\
\text { monitoring visits; identify gaps } \\
\text { and best practices to further }\end{array}$ \\
\hline
\end{tabular}




\begin{tabular}{|c|c|c|}
\hline Process & Person/s and Institution/s Involved & Roles and Functions \\
\hline & & $\begin{array}{l}\text { strengthen } \\
\text { implementation, information } \\
\text { dissemination, and provide } \\
\text { policy recommendations }\end{array}$ \\
\hline
\end{tabular}

\section{Assessment System}

22. The Assessment System includes both formative assessments that provide feedback for teachers to improve instruction in the classroom and evaluations that will check the effectiveness of MTB-MLE instruction across grade levels and regions.

23. Early Language Literacy and Numeracy Assessment (ELLNA) in the MT should only be administered to learners whose MT is used for language literacy and as MOTL. Learners whose MT is not used as MTOL should not be allowed to take the test until such time that his/her MT is used as MOTL, but they may take the Filipino and English components of the ELLNA.

\section{Recruitment and Training of Teachers}

24. Schools Division Superintendents must strictly adhere to the policy on the deployment of teacher items and prioritize the hiring of qualified teachers with due consideration of the needs of MTB-MLE implementation as stipulated in the teacher hiring guidelines.

25. In the hiring and deployment of teachers for Kindergarten to Grade 3, the SDOs must prioritize teachers who exhibit MT proficiency and who are wellequipped to teach beginning reading. Deployment should give priority to those teachers whose MT matches that of the learners. In cases where there are no MT speaking teachers in the division, priority must be given to teachers who speak the lingua franca of the broader area where the school is situated. The teacher then may be supported during class hours by a parent or community volunteer. For schools serving IP learners, DO No. 50, s. 2016 provides guidance regarding options and considerations related to this concern.

26. School Heads shall organize and monitor Learning Action Cells for all Kindergarten to Grade 3 teachers as a venue for continuous and cost-effective inservice training and teacher development. Early grades teachers are encouraged to initiate and facilitate these collaborative learning sessions with other teachers. LACs can be used to share and discuss best practices in the teaching of MT and to develop MT teaching and learning materials to be used in the classroom.

27. Kindergarten to Grade 3 teachers, as well as school heads, and MTBMLE coordinators are encouraged to pursue continuous professional development by attending teacher-training programs, seminars, and/or conferences on areas, such as but not limited to: MT proficiency (especially if the teacher is not a native 
speaker of the MT of the learners), bridging, best practices in MTB-MLE implementation, MT materials development and contextualization, developmentally appropriate practices, teaching beginning reading and other early language literacy and numeracy (ELLN) approaches and strategies.

\section{E. Community support}

28. Community support for the program should be built through advocacy and awareness-raising activities among parents and the community, local businesses, local universities, Local Government Units (LGUs), Non-governmental Organizations (NGOs), and other stakeholders, and through the engagement of the community in developing learning resources and implementation of the program.

29. A crucial dimension in community engagement is the process of seeking the community's consent, which should be facilitated by customary elders and leaders before any intervention is initiated. The consent-seeking process shall be initiated by the SDO through an initial consultation with recognized community customary leaders and elders. The MTB-MLE's rationale, goals, and objectives shall be discussed with the community including its relationship to the Indigenous Peoples Education (IPEd) Program. The community's particular process of giving consent shall be recognized and respected.

30. Should the community give its consent to the implementation of MTBMLE, specific standards, protocols and agreements shall be formulated with the community, which in turn shall govern the implementation of the procedures elaborated in the succeeding sections.

31. Community engagement at every stage of program implementation is vital to the success of the program. Mobilization of community support can be in the form of the following:

a. Strengthening awareness on MTB-MLE among parents, community members, and other stakeholders through promotion and information campaign;

b. Identifying social actors (social mapping) in the community/district/division/regions and assigning their key roles in MTB-MLE implementation and education advocacies;

c. Developing with the community the criteria and indicators for culturesensitive learning materials and agreements regarding intellectual property rights;

d. Identifying parents or community volunteers who can provide support to teachers who are not speakers of the community's MT but are the only teachers available;

e. Training identified community members in the process of MTB-MLE implementation; 
f. Encouraging home support through parental and caregiver involvement in the different program components, such as materials development, advocacy, capacity building and others;

g. Promoting partnership and networking opportunities with expert groups and individuals; and,

h. Soliciting support from LGUs and other stakeholders for MTB-MLE campaigns and other education advocacies. (e.g. support for reproduction of learning resources; honoraria of community volunteers).

32. In recognition of the fact that many of the languages in the country are those of indigenous cultural communities (ICC)/IPs, implementation of the MTBMLE Program in relation to IP communities shall adhere to the community engagement process discussed in DO No. 32, s. 2015 (Section V.A.1), which highlights the need for sustained dialogue between the ICCs and DepEd on curriculum development.

33. For SDOs that have developed an IPEd Framework (as articulated in Section VI. 1 of DO No. 32, s. 2015), MTB-MLE implementation shall be guided and situated in the context of the said framework. The formulated standards, protocols, and agreements shall form part of the SDO's IPEd Framework.

\section{Procedure}

\section{Preliminary Scanning and Appraisal}

34. It should be noted that the main focus of the MTB-MLE program is the language of the students. In order to effectively implement MTB-MLE, some background information about the language of the students, the teachers, and the community shall be collected. This preliminary research shall identify the strengths and weaknesses of MTB-MLE implementation in the schools and divisions involved.

35. DO No. 55, s. 2015 specifies the language mapping procedures using the Learner Information System (LIS) that should be done every beginning of the school year. The language mapping data identifies the percentage of learners who speak the MT languages used in schools. The language mapping also forms part of the scanning and appraisal that is needed for planning a localized MTB-MLE program for languages currently not used by the Department. The data shall serve as a basis for deciding which languages shall be used in MTB-MLE implementation.

36. To further support evidence-based decision-making, school heads and SDOs are also enjoined to gather other information about the community, such as:
a. Challenges on MTB-MLE implementation;
b. Information about the community's attitudes towards the local and national languages;
c. Attitudes towards literacy in the local and national languages;
d. Information about the community's use of literacy in the language; and, 
e. Availability of resource persons or other resources (technical, financial, etc.) that promote or sustain MTB-MLE program practices.

37. Gathering of these information can be done through research and monitoring and evaluation. Scanning and appraisal results can then inform efforts towards developing the minimum requirements for the MT to be used in schools described below (See Appendices 1 and 2). The SDOs shall spearhead the mobilization, recruitment and training of individuals and groups within and outside the community who will help in the planning and implementation of a localized MTBMLE program that serves the community's needs. SDOs must then inform their respective Regional Offices (ROs) if other languages are being or will be used to implement MTB-MLE in their divisions, and provide status reports (i.e. number of teachers, number of learners, availability of MT materials, etc.) and documentation of best practices. SDOs must create a database to keep track of all languages used in the MTB-MLE program in the schools. The ROs and the Central Office are expected to collate and utilize these reports to keep track of the MOTL used in schools.

38. Appendix 1 contains a "Rapid Appraisal of Languages for Mother Tongue-Based Multilingual Education (MTB-MLE)" questionnaire to check whether the language can be used to implement MTB-MLE. Appendix 2 contains descriptive notes on the minimum requirements for MTB-MLE implementation, which include:

a. Presence of MT speaking teachers from Kindergarten to Grade 3;

b. A locally accepted orthography for writing the language including a primer lesson or primer teacher's guide to systematically teach the orthography;

c. An officially documented vocabulary (e.g. word list, glossary, thesaurus, mono- or multilingual dictionary);

d. A spelling guide or grammar book; and,

e. A literature or reading materials (e.g. big books, small books, listening stories, busy pictures, etc.)

39. Once these criteria are met, the concerned SDOs shall recognize the additional language/s and shall supervise contextualization efforts in schools. Documentation supporting the use of the language/s must be forwarded to the Regional Office and the Bureau of Learning Delivery. Other MT languages with orthography may be included in DepEd's roster of languages used in national assessments. The bureaus under the DepEd Curriculum and Instruction strand must deliberate if the language will be included in the ELLNA.

40. School Heads are enjoined to utilize the School MOOE, local school board funds and other education improvement funds for the development, printing, and distribution of Teacher's Guides, MT reading materials, and other instructional materials (DO No. 74, s. 2009). 


\section{Instruction: Language Transition Program}

41. Explicit in the $\mathrm{K}$ to 12 Basic Education Program is the understanding that language plays a strategic role in shaping the formative years of learners. As such, the learner's MT shall serve as the fundamental language of education in Kindergarten to Grade 3.

42. DepEd believes that all children can and should be able to read during their early grades. The program promotes the development of language and literacy skills in the learner's MT first as these skills develop more easily and efficiently using the language that the learner knows and speaks. Such language and literacy skills in the learner's MT will serve as a springboard for the development of literacy in other languages in the curriculum. Its goal is to provide transitioning students with the support they need to gradually and effectively move from MT instruction to mostly Filipino and/or English Instruction.

43. The teacher must be well-equipped in using the MT (L1) as MTOL to help children develop concepts in various learning areas. The teacher should consistently use the MT as the MOTL; translation is not advisable unless this forms part of the learning objectives and is used as a teaching strategy in bridging.

44. Oral language proficiency is a prerequisite for literacy development. Thus, in Grade 1, Filipino shall be introduced in the second quarter, and English shall be introduced in the third quarter to develop oral fluency in both languages prior to the introduction of literacy development lessons.

45. Filipino (L2) and English (L3) are gradually introduced as languages of instruction until such time when these two languages can become the primary languages of instruction at the secondary level. The learners may use their MT in expressing their answers if they find it difficult to use the target language (e.g. in Filipino or English subjects). The teacher can then subtly translate the learners' answer to the target language.

46. The bridging of language and literacy across L 1 to L3 is shown in Table 4.3.

Table 4.3. Bridging of Language and Literacy Across Languages

\begin{tabular}{|l|l|l|l|}
\hline \multicolumn{1}{|c|}{ Kindergarten } & \multicolumn{1}{c|}{ Grade 1 } & \multicolumn{1}{c|}{ Grade 2 } & \multicolumn{1}{c|}{ Grade 3 } \\
\hline $\begin{array}{l}\text { Build oral fluency } \\
\text { in L1 }\end{array}$ & $\begin{array}{l}\text { Continue } \\
\text { developing oral } \\
\text { fluency in L1 }\end{array}$ & $\begin{array}{l}\text { Continue } \\
\text { developing oral } \\
\text { fluency in L1 }\end{array}$ & $\begin{array}{l}\text { Continue } \\
\text { developing oral } \\
\text { fluency in L1 }\end{array}$ \\
\hline $\begin{array}{l}\text { L1 pre-reading } \\
\text { and pre-writing }\end{array}$ & $\begin{array}{l}\text { Introduce L1 } \\
\text { literacy }\end{array}$ & $\begin{array}{l}\text { Continue } \\
\text { developing L1 } \\
\text { literacy }\end{array}$ & $\begin{array}{l}\text { Continue } \\
\text { developing L1 } \\
\text { literacy }\end{array}$ \\
\hline & MT as subject & MT as subject & MT as subject \\
\cline { 2 - 5 } & $\begin{array}{l}\text { Learning areas are } \\
\text { taught in L1 }\end{array}$ & $\begin{array}{l}\text { Learning areas are } \\
\text { taught in L1 }\end{array}$ & $\begin{array}{l}\text { Learning areas are } \\
\text { taught in L1 }\end{array}$ \\
\hline
\end{tabular}




\begin{tabular}{|l|l|l|l|}
\hline Kindergarten & \multicolumn{1}{|c|}{ Grade 1 } & \multicolumn{1}{c|}{ Grade 2 } & \multicolumn{1}{c|}{ Grade 3 } \\
\hline & $\begin{array}{l}\text { Begin oral fluency } \\
\text { in L2 } \\
\text { (Second Quarter) }\end{array}$ & $\begin{array}{l}\text { Continue } \\
\text { developing oral } \\
\text { fluency in L2 }\end{array}$ & $\begin{array}{l}\text { Continue } \\
\text { developing oral } \\
\text { fluency in L2 }\end{array}$ \\
\cline { 2 - 4 } & $\begin{array}{l}\text { Introduce literacy } \\
\text { in L2 } \\
\text { (Fourth Quarter) }\end{array}$ & $\begin{array}{l}\text { Continue } \\
\text { developing L2 } \\
\text { literacy }\end{array}$ & $\begin{array}{l}\text { Continue } \\
\text { developing L2 } \\
\text { literacy }\end{array}$ \\
\cline { 2 - 4 } & $\begin{array}{l}\text { Begin oral fluency } \\
\text { in L3 } \\
\text { (Third Quarter) }\end{array}$ & $\begin{array}{l}\text { Continue } \\
\text { developing oral } \\
\text { fluency in L3 }\end{array}$ & $\begin{array}{l}\text { Continue } \\
\text { developing oral } \\
\text { fluency in L3 }\end{array}$ \\
\cline { 2 - 4 } & $\begin{array}{l}\text { Introduce L3 } \\
\text { literacy } \\
\text { (Second Quarter) }\end{array}$ & $\begin{array}{l}\text { Continue } \\
\text { developing L3 } \\
\text { literacy }\end{array}$ \\
\hline
\end{tabular}

47. Bridging aids in transferring concepts and skills learned in one language to another language, and in exploring the similarities and differences of the languages. Certain concepts and skills (such as book and print knowledge or phonological awareness skills) are easily transferred from one language to another. This is especially true when languages share similarities in orthography or writing systems. Other skills (e.g. vocabulary) are less easily transferred and would require explicit and systematic instruction for the learner to develop using other languages. Teachers should be aware of the similarities and differences among languages so that they can effectively develop their learners' language and literacy skills in L2 and L3. Tables 4.4, 4.5, and 4.6 show various bridging plans for different $L 1, L 2$, and $L 3$.

Table 4.4. MTB-MLE Bridging Plan: MT as L1, Filipino as L2, and English as L3

\begin{tabular}{|l|l|l|l|l|l|l|}
\hline Grade Level & MT & Math & Science & $\begin{array}{c}\text { EsP/ } \\
\text { AP/ } \\
\text { MAPEH }\end{array}$ & Filipino & English \\
\hline Grade 3 & L1 & L3* & L3* & L2 & L2 & L3 \\
\hline Grade 2 & L1 & L1 & L1 & L1 & L1 \\
\hline Grade 1 & L1 & & L1 & L2 & L3 \\
\hline Kindergarten & L1 & L1 & & L1 & L2 & L3 \\
\hline
\end{tabular}

*if academic language (i.e. terminologies) are in English

48. The MTB-MLE bridging plan in Table 4.4 may apply to majority of the learners whose MT or L1 is used as the MOTL for the early grades. Filipino is introduced as a subject in Grade 1 during the second quarter to develop oral language and in the fourth quarter to develop literacy. English, on the other hand, 
is introduced as a subject during the third quarter in Grade 1 to develop oral language and in the first quarter in Grade 2 to develop literacy. Filipino and English language skills are gradually developed among the learners. For example, Filipino and English academic content vocabulary is gradually introduced during the fourth quarter of Grade 3 as a bridge to prepare the learners for Filipino and English not only as a subject but also as an MOTL for the subjects in Grade 4 to Grade 6.

Table 4.5. MTB-MLE Bridging Plan: Filipino as L1, English as L2

\begin{tabular}{|l|l|l|l|l|l|}
\hline Grade Level & Filipino & \multicolumn{1}{|c|}{ Math } & Science & $\begin{array}{c}\text { EsP/ AP / } \\
\text { MAPEH }\end{array}$ & English \\
\hline Grade 3 & L1 & L2* & L2* & & L2 \\
\hline Grade 2 & L1 & L1 & L1 & L1 \\
\hline Grade 1 & L1 & L1 & & L1 & L2 \\
\hline Kindergarten & & L1 & & L1 & L2 \\
\hline
\end{tabular}

*if academic language (i.e. terminologies) are in English

49. The MTB-MLE bridging plan in Table 4.5 may apply to learners whose MT is Tagalog or Filipino. Teachers teach Tagalog during MT class time using the MT Tagalog curriculum, Teacher's Guide, and Learner's Materials. L2 (English) is introduced as a subject during the second quarter in Grade 1 to develop oral language and in the fourth quarter in Grade 1 to develop literacy. English academic content vocabulary is gradually introduced during the fourth quarter in Grade 3 as a bridge to prepare the learners for English not only as a subject but also as an MOTL for the subjects in Grade 4 to Grade 6.

Table 4.6. MTB-MLE Bridging Plan: English as L1, Filipino as L2

\begin{tabular}{|l|l|l|l|l|l|}
\hline \multicolumn{1}{|c|}{ Grade Leve1 } & English & Math & Science & $\begin{array}{c}\text { EsP/ AP/ } \\
\text { MAPEH }\end{array}$ & \multicolumn{1}{|c|}{ Filipino } \\
\hline Grade 3 & L1 & L1 & L1 & L2 & L2 \\
\hline Grade 2 & L1 & L1 & & L1 & L2 \\
& & & & L1 & L1 \\
\hline
\end{tabular}




\begin{tabular}{|l|l|l|l|l|l|}
\hline \multicolumn{1}{|c|}{ Grade Leve1 } & English & Math & Science & $\begin{array}{c}\text { EsP/ AP/ } \\
\text { MAPEH }\end{array}$ & Filipino \\
\hline Grade 1 & L1 & L1 & & L1 & L1 \\
& & & & L1 & \\
\hline Kindergarten & \multicolumn{3}{|c|}{} \\
\cline { 1 - 5 }
\end{tabular}

50. The MTB-MLE bridging plan in Table 4.6 may apply to a small group of learners whose MT is English. All learning areas are taught using L1 (English) as MOTL. However, academic content vocabulary for Filipino, EsP, AP, and MAPEH are gradually introduced starting Grade 2, as Filipino becomes the MOTL for these subjects starting Grade 4.

\section{Instruction: Class Sectioning}

51. Several variables have to be taken into consideration when planning for class sectioning. Some of the factors that can help the school heads decide on class sectioning are the following: (1) learners' MT (taken from the language mapping process); (2) teachers' MT or other languages spoken; (3) class size or number of enrollees per grade level; and, (4) availability of MT instructional materials. A learner-centered curriculum means that the learner's MT is the primary consideration for class sectioning and for the MOTL to be used in class. If teachers are not familiar with the learners' MT, the schools are encouraged to engage parent and community volunteers to help the teachers. If materials are not available, effort should be taken to develop or contextualize materials as necessary. Table 4.7 shows the class models in MTB-MLE implementation.

Table 4.7. Class Models in MTB-MLE

\begin{tabular}{|c|c|}
\hline Situation & Class Model \\
\hline One School - One Class - One Language & Basic Monolingual 1 \\
\hline $\begin{array}{l}\text { One School }- \text { Two Classes }- \text { Two } \\
\text { Languages }\end{array}$ & $\begin{array}{l}\text { Basic Monolingual } 2 \\
\text { Group students according to their } \\
\text { language and match it with that of the } \\
\text { teacher. Each section uses a different } \\
\text { MT. }\end{array}$ \\
\hline $\begin{array}{l}\text { One School - Multiple Classes - Multiple } \\
\text { Languages }\end{array}$ & $\begin{array}{l}\text { Modified Monolingual } \\
\text { Group the learners according to their } \\
\text { language and match it with that of the } \\
\text { teacher }\end{array}$ \\
\hline
\end{tabular}




\begin{tabular}{|l|l|}
\hline \multicolumn{1}{|c|}{ Situation } & \multicolumn{1}{c|}{ Class Mode1 } \\
\hline $\begin{array}{l}\text { One School - One Class - Multiple } \\
\text { Languages }\end{array}$ & $\begin{array}{l}\text { 1. One class can be monolingual } \\
\text { 2. One or two classes can be bi- or tri- } \\
\text { lingual (assistance from the parents who } \\
\text { are native speakers is necessary) }\end{array}$ \\
& $\begin{array}{l}\text { Use of the community language. } \\
\text { Assistance from parents / community } \\
\text { volunteers may be enlisted to help } \\
\text { learners bridge their MT to their lingua } \\
\text { franca. }\end{array}$ \\
\hline
\end{tabular}

52. In schools where there are three or more MTs or variations of the language without an approved orthography of the language spoken by the learners, teachers can use the lingua franca as the MOTL provided that it is used and understood by the learners. In this case, the lingua franca is used as the auxiliary MOTL. Special classes offering the learners' MT may be held twice a week for the development of oral fluency. The oral fluency skills shall be bridged to any of the languages widely-used or commonly-used in the area in the development of reading and writing (DO No. 16, s. 2012, DO No. 55, s. 2015). Table 4.8 shows examples of MTB-MLE implementation plans with different factors and variations.

Table 4.8. Examples of MTB-MLE Implementation Plans

\begin{tabular}{|c|c|c|c|c|}
\hline \multicolumn{4}{|c|}{ Factors to Consider } & \multirow{2}{*}{$\begin{array}{c}\text { Suggested } \\
\text { Class Model } \\
\text { (as articulated } \\
\text { in Table 4.7) }\end{array}$} \\
\hline Learners' MT & Teachers' MT & Class Size & MT Materials & \\
\hline $\begin{array}{l}\text { All learners } \\
\text { have the same } \\
\text { MT }\end{array}$ & $\begin{array}{l}\text { Teacher knows } \\
\text { and speaks } \\
\text { learners' MT }\end{array}$ & $\begin{array}{l}\text { Small school - } \\
\text { one section } \\
\text { per grade level }\end{array}$ & $\begin{array}{l}\text { MT materials } \\
\text { available }\end{array}$ & $\begin{array}{l}\text { Basic } \\
\text { Monolingual } 1\end{array}$ \\
\hline $\begin{array}{l}\text { Learners' MT } \\
\text { vary ( } 2 \\
\text { languages) }\end{array}$ & $\begin{array}{l}\text { Teacher knows } \\
\text { and speaks } \\
\text { learners' MT }\end{array}$ & $\begin{array}{l}\text { Big school - } \\
\text { many sections } \\
\text { per grade level }\end{array}$ & $\begin{array}{l}\text { MT materials } \\
\text { available }\end{array}$ & $\begin{array}{l}\text { Basic } \\
\text { Monolingual } 2\end{array}$ \\
\hline $\begin{array}{l}\text { Learners' MT } \\
\text { vary ( } 2 \\
\text { languages) }\end{array}$ & $\begin{array}{l}\text { Teacher knows } \\
\text { and speaks } \\
\text { learners' MT }\end{array}$ & $\begin{array}{l}\text { Big school - } \\
\text { many sections } \\
\text { per grade level }\end{array}$ & $\begin{array}{l}\text { Only materials } \\
\text { in the } \\
\text { regional/ } \\
\text { community } \\
\text { language }\end{array}$ & $\begin{array}{l}\text { Modified } \\
\text { monolingual }\end{array}$ \\
\hline
\end{tabular}




\begin{tabular}{|l|l|l|l|l|}
\hline \multicolumn{3}{|c|}{ Factors to Consider } & $\begin{array}{l}\text { Suggested } \\
\text { Class Model } \\
\text { (as articulated } \\
\text { in Table 4.7) }\end{array}$ \\
\hline $\begin{array}{l}\text { Learners' MT } \\
\text { vary (3 or more } \\
\text { languages) }\end{array}$ & $\begin{array}{l}\text { Teachers' MT } \\
\text { familiar with } \\
\text { all learners' } \\
\text { MT* }^{*}\end{array}$ & $\begin{array}{l}\text { Class Size } \\
\text { one section } \\
\text { per grade level } \\
\text { only }\end{array}$ & $\begin{array}{l}\text { MT Materials } \\
\text { available (one } \\
\text { of the 19 MT) }\end{array}$ & $\begin{array}{l}\text { Lingua Franca, } \\
\text { with special } \\
\text { lasses for the } \\
\text { learners' MT } \\
\text { offered twice a } \\
\text { week }\end{array}$ \\
\hline $\begin{array}{l}\text { Learners' MT } \\
\text { vary (3 or more } \\
\text { languages) - } \\
\begin{array}{l}\text { Learners are } \\
\text { not familiar } \\
\text { with the lingua } \\
\text { franca }\end{array}\end{array}$ & $\begin{array}{l}\text { Teacher is not } \\
\text { familiar with } \\
\text { all learners' } \\
\text { MT* }\end{array}$ & $\begin{array}{l}\text { Small school, } \\
\text { one section } \\
\text { per grade level } \\
\text { only }\end{array}$ & $\begin{array}{l}\text { MT materials } \\
\text { available (one } \\
\text { of the 19 MT) }\end{array}$ & $\begin{array}{l}\text { Basic } \\
\text { Monolingual 1 - } \\
\text { but team } \\
\text { teaching with } \\
\text { community } \\
\text { volunteer is } \\
\text { needed }\end{array}$ \\
\hline
\end{tabular}

* Such cases should be noted by SDO, and hiring of MT speaking teachers should be addressed as soon as possible.

53. Teachers can work together with parent or community volunteers via team teaching. The teacher takes the lead in lesson planning and works closely with parent or community volunteer in implementing the lessons in MT during class hours.

\section{Assessment}

54. Teachers must adhere to the guidelines on Classroom BasedAssessment in DO No. 8, s. 2015 to monitor learner progress throughout the school year and to provide interventions as necessary.

55. The assessment of learning must be anchored on the MOTL.

56. At the end of Grade 3, students are assessed in three languages through the ELLNA.

\section{Program Management}

57. School heads must monitor the implementation of MTB-MLE in schools through class observations and validation of the language mapping data submitted by teachers. SDOs must conduct an inventory of the teachers' MT and other languages spoken to inform teacher hiring and deployment decisions (DONo. 55, s. 2015). SDOs and School Heads use language mapping data either collected in school or gathered from PS-EMIS to determine the class size and composition of students 
with the same MT and the class adviser assigned to each class. Teachers are enjoined to complete the Classroom-level Language Mapping Validation Form in Appendix C of DO No. 55, s. 2015 as a means to determine that the language/s spoken by the Class Adviser match the learners' MT.

58. Community support can be heightened or sustained through the launching of appropriate curricular and extracurricular activities that promote the use of MT in and out of classrooms.

59. Curriculum and Learning Management Division (CLMD) and Curriculum Implementation Division (CID) of SDOs are enjoined to document and disseminate best practices in MTB-MLE implementation through lesson studies and LAC sessions, action researches, etc.

60. The use of lingua franca is a temporary substitute for MTB-MLE implementation. The end goal is the use of the learners' MT as MOTL throughout the first key stage of schooling. CO, ROs, DOs, and schools shall continuously work with the community and other stakeholders in meeting the four (4) minimum requirements of MTB-MLE implementation so that other languages can be included in the list of languages that the Department is using for MTB-MLE implementation.

\section{Monitoring and Evaluation (M\&E)}

61. Teachers and School Heads must regularly conduct an inventory of available MTB-MLE teaching and learning materials at the end of the school year. This inventory will determine if other MTB-MLE materials need to be acquired, developed, and/or contextualized. This information shall be submitted to the district, division, and regional levels.

62. The Quality Assurance and the School Governance and Operations Divisions in the Region and Schools Division levels respectively are required to conduct monitoring, provide technical assistance, and gather best practices and feedback to ascertain that every school is in compliance with the herein policy for quality implementation of the MTB-MLE Program. Results will inform quality of program implementation, information dissemination, and policy recommendation. The CLMD and CID are also required to continuously monitor and provide technical assistance to schools and provide feedback to the Central Office during CLMD meetings.

63. The Teaching and Learning Division (TLD) from the Bureau of Learning Delivery shall continuously monitor and provide technical assistance to the Curriculum and Learning Management Division (CLMD) and to the Curriculum Implementation Division (CID). 


\section{References}

Asia-Pacific Multilingual Education Working Group. 2013. Mother Tongue Based Multilingual Education: Lessons Learned from a Decade of Research and Practice. Key messages from the 4th International Conference on Language and Education.

Education Sector Analytical and Capacity Development Partnership (ACDP). 2014. Mother Tongue Based Multilingual Education. Ministry of Education and Culture National Office for Research and Development.

Department of Education Order No. 74, s. 2009, Institutionalizing Mother Tongue-Based Multilingual Education (MLE).

Department of Education Order No. 16, s. 2012, Guidelines on the Implementation of the Mother Tongue-Based- Multilingual Education (MTBMLE).

Department of Education Order No. 7, s. 2015, Hiring Guidelines for Teacher I Positions for School Year (SY) 2015-2016.

Department of Education Order No. 22, s. 2015, Hiring Guidelines for the Remaining Teaching Positions Effective School Year (SY) 2015-2016.

Department of Education Order No. 32, s. 2015, Adopting the Indigenous Peoples Education Curriculum Framework.

Department of Education Order No. 44, s. 2015, Guidelines on the Enhanced SIP Process and the School Report Card.

Department of Education Order No. 55, s. 2015. Utilization of Language Mapping Data for Mother Tongue-Based Multilingual Education (MTB-MLE) Program Implementation.

Implementing Rules and Regulations of Republic Act No. 10533. Enhanced Basic Education Act of 2013.

Malone, S. 2010. Planning mother tongue-based education programs in minority language communities: Resource manual for speakers engaged in planning and implementing mother tongue-based education programs in their own communities. SIL International. Retrieved from http://www.sil.org /system/files/reapdata/70/48/16/70481663076073369953923515282904 48531/MLE_Program_Planning_manual.pdf

Metila, R. 2016. Materials Strategies in Philippine MTB-MLE Implementation. Presentation at the Workshop on the Protocols for Contextualization of Mother Tongue-Based Teaching Learning Materials, Mandaluyong. May 3$5,2016$. 
Ocampo, D., Diaz, L., Padilla, P.2006. Basic Education Sector Reform Agenda.

Pado, F. 2012. Kindergarten to Grade 3 and 21 $1^{\text {st }}$ Century Literacies.

Presentation prepared for the 2012 Reading Association of the Philippines

Annual National Convention.

Republic Act No. 10533. Enhanced Basic Education Act of 2013

Smits, J., J. Huisman, and K. Kruijff. 2008. Home language and education in

the developing world. Background paper prepared for the Education for All

Global Monitoring Report 2009.

Trudell, B., and Young, C., (eds.). Good answers to tough questions in mother

tongue-based multilingual education. 2016. Retrieved from

http: / / www.sil.org/literacy-education/good-answers-tough-

questions-

mother-tongue-based-multilingual-education 


\section{Appendix 1. Rapid Appraisal of Languages for Mother Tongue-based Multilingual Education (MTB-MLE) Implementation}

\section{Schools Division Questionnaire}

This questionnaire is intended to assess readiness in using a particular language for the implementation of MTB-MLE. Specifically, it looks into: (1) the status of a locally accepted orthography for writing the language, and (2) availability of educational materials in the language (Big Books, Small Books; Spelling Guide and a Grammar book for the language; a basic reading primer; a pupils' dictionary or wordlist).

\begin{tabular}{ll}
\hline Language: & Region: \\
Division: & Noted by: \\
Submitted by: & \\
& \\
Division MTB-MLE Coordinator & Schools Division Superintendent \\
\hline
\end{tabular}

Please tick under the appropriate column (Yes or No). If unsure, please leave the item blank.

\begin{tabular}{|c|c|c|}
\hline & YES & NO \\
\hline \multicolumn{3}{|l|}{ I. Working Orthography } \\
\hline \multicolumn{3}{|l|}{ A. Orthography Status } \\
\hline \multirow{2}{*}{\multicolumn{3}{|c|}{$\begin{array}{l}\text { 1. Is the language written by the people? } \\
2 . \text { Is there generally consistency as to how it is written? }\end{array}$}} \\
\hline & & \\
\hline \multicolumn{3}{|l|}{ 3. Is there community-wide acceptance of the written form? } \\
\hline \multicolumn{3}{|l|}{$\begin{array}{l}\text { 4. Has the community published or does it publish anything } \\
\text { in the language? }\end{array}$} \\
\hline \multicolumn{3}{|l|}{$\begin{array}{l}\text { 5. Are there variations in how the language is written in } \\
\text { other communities that identify with the language? }\end{array}$} \\
\hline \multicolumn{3}{|l|}{ B. Spelling Guide } \\
\hline \multicolumn{3}{|l|}{$\begin{array}{l}\text { 1. Is there a spelling guide (documenting the orthography) } \\
\text { for this language? }\end{array}$} \\
\hline \multicolumn{3}{|l|}{ 2. Are illustrated alphabet charts included? } \\
\hline \multicolumn{3}{|l|}{$\begin{array}{l}\text { 3. Are there tables with examples of words to illustrate use } \\
\text { of the letters? }\end{array}$} \\
\hline \multicolumn{3}{|l|}{ C. Alphabet Primers } \\
\hline \multicolumn{3}{|l|}{$\begin{array}{l}\text { 1. Is there an alphabet primer or primer lessons in this } \\
\text { language? }\end{array}$} \\
\hline \multicolumn{3}{|l|}{$\begin{array}{l}\text { 2. If there is an alphabet primer, does it appear that there is } \\
\text { a lesson for each letter? }\end{array}$} \\
\hline \multicolumn{3}{|l|}{ II. Dictionary - Current Status } \\
\hline $\begin{array}{l}\text { A. Is there a wordlist or collection of expressions / phrases in } \\
\text { the language with the corresponding meanings in another } \\
\text { language (Filipino and/or English; in some instances, } \\
\text { perhaps in another Regional language)? }\end{array}$ & & \\
\hline
\end{tabular}




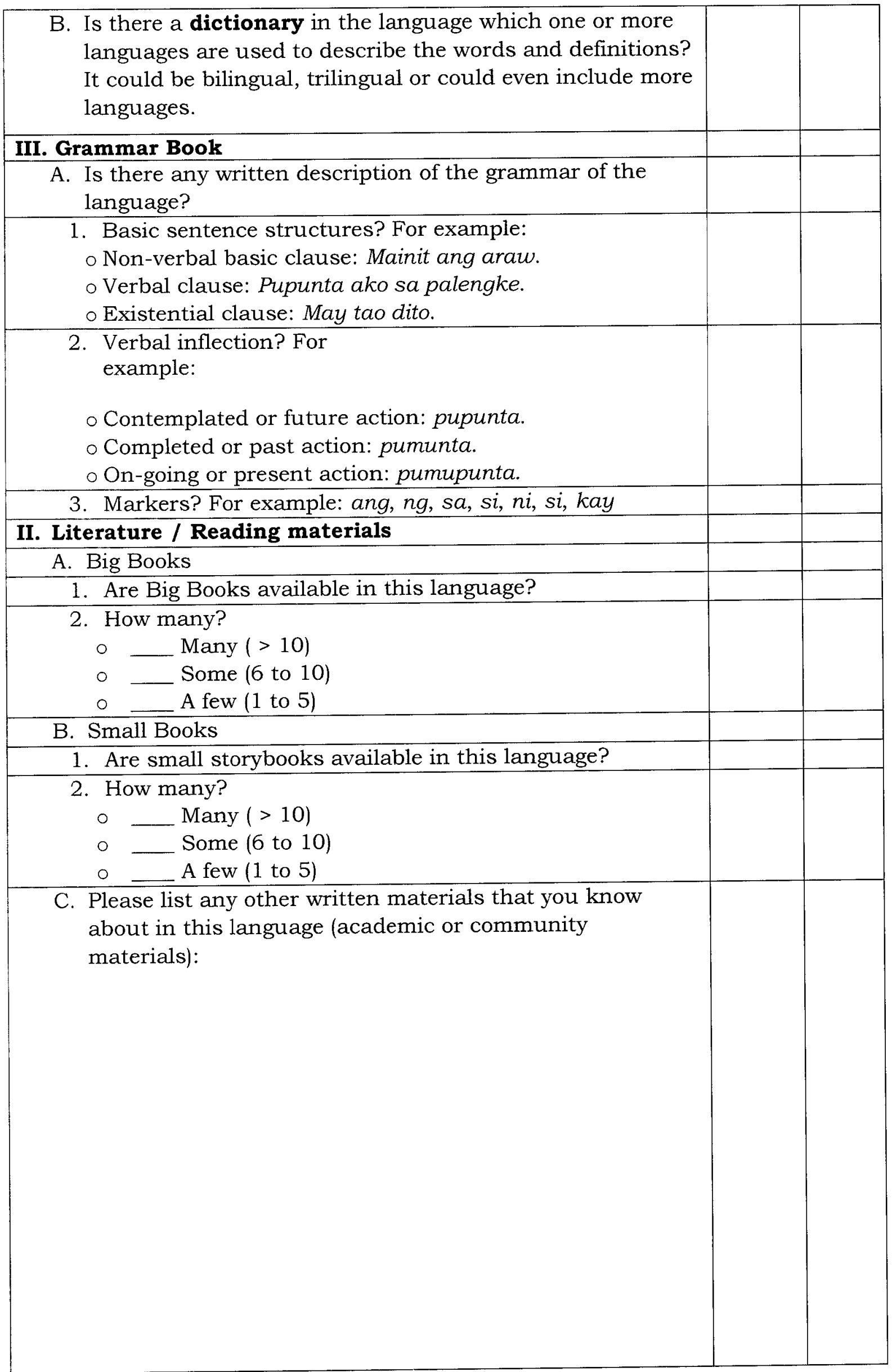




\section{Appendix 2. Four Minima for MTB-MLE implementation}

\section{Orthography}

The first step in assessing an orthography or writing system is to check if the alphabet satisfies the following:

- acceptable to the stakeholders (the community who speaks the language, and the linguists who can vouch for its soundness);

- can be used to adequately represent the language in written form;

- easy to learn (teachable);

- easy to transfer (to other languages); and

- easy to reproduce.

\section{Officially Documented Vocabulary}

Documentation of vocabulary of a particular language may be in a form of:

- Glossary: vocabulary in specific contexts

- Dictionary3: a book or electronic resource that lists the words of a language (typically in alphabetical order) and gives their meaning, or gives the equivalent words in a different language, often also providing information about pronunciation, origin, and usage.

There are different kinds of Dictionaries:

a. Monolingual dictionary: a dictionary in which both the words and definitions are all in one language.

b. Multilingual dictionary: a dictionary in which one or more languages are used to describe the words and definitions. It can be bilingual, trilingual or could even include more languages.

c. Encyclopedic Dictionary: Designed to present and discuss words according to subject matter.

- Encyclopedias: The entries are essays on topics, listed in alphabetical order.

- Thesaurus4: a book or set of books giving information on many subjects or on many aspects of one subject and typically arranged alphabetically.

\section{Grammar Book}

A Grammar Book contains the grammar structure of the language with example of its application to words, phrases, and sentences. A Spelling Guide is intended to document the currently approved or accepted orthography in the form of a readable reference guide for teachers to use in preparing lessons and teaching, to help achieve uniformity in how the language is represented in written form in all schools throughout the language area. The Guide should include:

- Spelling rules- Letters of the orthography and the spelling rules are written systematically and with examples first in their entirety in the vernacular, and then again in Filipino and finally in English.

- Alphabet tables - Next are tables of the letters of the vernacular alphabet with several examples of words in which the letter occurs word-initially, then several examples in which the letter occurs word-medially, and several examples in which the letter occurs word-finally. Note that not all sounds might occur in all three positions, and that will be noted where it is the

\footnotetext{
${ }^{3}$ Retrieved from https://en.oxforddictionaries.com/definition/dictionary on April 2019

+ Retrieved from https://en.oxforddictionaries.com/definition/encyclopedia on April 2019
} 
case. The English and/or Filipino equivalent of each word should also be listed in separate columns.

- Alphabet charts - Next are alphabet charts, listing each letter and a vernacular word, usually a word that begins with the symbol, and an accompanying illustration. The illustrated letters are presented in groupings of vowels and consonants and then again in alphabetical order. When the alphabet charts are completed, they can be reproduced and enlarged to post in the classrooms; and individual alphabet cards can also be produced to post and use with the pupils.

- Tables of words by domain

- Dictionary section

\section{Literature: things to read}

\section{Big Books}

Big Books are illustrated stories produced in book form in a size large enough for a whole class to see the illustrations and printed words. The typical size is 13 inches by 19 inches (A3 size paper). These books are to be used in shared reading activities. It is most desirable that the stories and the illustrations, come from the community, and that they are tested in and approved by the community. The stories should be authored by community members if possible, and then tested in and approved by the community.

The typical and recommended Big Book format will have an illustration on the left side when facing the open book, and with text on the right side. The illustration should be relatively simple, with clear artwork that communicates what the text on the facing page is saying.

The text should be written in letters large enough to read from the back of the typical classroom. It should not be too long. Especially for the earliest Big Books, the text should have a lot of repetition and predictability.

Enough Big Books should be produced so that there will be one or two new Big Books available each week throughout the academic year, and the books for the week should relate to the theme of the curriculum for that week if possible.

The level of complexity of Big Book stories should increase gradually as beginning readers improve their skills. At the beginning of Grade 1, most pupils should be expected to be at Level 1, learning to read their L1. Big Books at this stage should have only four to eight page sets (illustration page plus the facing text page forms one set) with only one sentence of text per text page. As pupils gain some mastery (later Level 1), Big Books can have six to ten page sets with one to three short sentences per text page (Malone 2013).

\section{Small Books}

Like Big Books, Small Books are illustrated stories, but for individual reading. Each page can have an illustration and text to help pupils practice reading. Black and white illustrations can be used, giving pupils opportunity to personalize their copy by coloring the illustrations and then keeping the book to practice at home with their parents. Small Books should also be graded to move to greater complexity as pupils gain skill in reading (see Malone 2013 for more information). 


\section{Listening Stories}

Listening Stories should be written by community members and used for reading aloud to children. They can be longer than Big Books or Small Books, but not so long that the children lose interest before reaching the end of the story (about two pages, or about five minutes of reading). Illustrations are not required because these stories are intended to stimulate imagination. Good stories will communicate action. They should use descriptive language, including sounds, expressions, and voices so that the reader can dramatize somewhat as they read, helping the children to imagine the scene. Such stories can foster interest in reading.

\section{Picture Stories/Wordless Picture Books}

These are sets of five or six illustrations that tell a story without the need for text. Pupils will organize the pictures in a logical sequence based on their ideas, and then make up a story using the pictures as the basis for the story.

\section{Big Picture}

A Big Picture is a large illustration that reflects the world the pupils see and experience in their communities. It can be a collage representing a collection of cultural activities reflecting familiar themes in the language community, drawn on one sheet of paper. A good size to use would be on the order of one meter in height by 80 centimeters in length. These sorts of materials develop children's visual skills, promote creative and critical thinking, and verbal expression. Visual arts or styles known and used in the culture can be integrated into such drawings. For example, designs used in textiles, clothing, baskets or houses can be represented in the drawing. These drawings can be used for Total Physical Response exercises, where pupils are to act out the words or instructions they hear. 


\section{References}

Cahill, Michael, and Rice, Keren. Developing Orthographies for Unwritten Languages. Dallas: SIL International, 2014.

Dictionary. (n.d.). Retrieved from Oxford Dictionaries: www.oxforddictionaries.com/definition/dictionary

Malone, S. (2010). Planning Mother Tongue-Based Education Programs in Minority Language Communities: Resource Manual for Speakers Engaged in Planning and Implementing Mother Tongue-Based Education Programs in their own communities. SIL International. Retrieved from http:/www.sil org/system/files/reapdata/70/48/16/70481663076073369 $95392351528290448531 /$ MLE Program Planning manual.pdf

Thesaurus. (n.d.). Retrieved from Oxford Dictionaries: www.oxforddictionaries.com/definition/thesaurus 


\section{ANNEX 5: INCLUSIVE EDUCATION POLICY FRAMEWORK FOR BASIC EDUCATION}

\section{Rationale}

1. The Department of Education (DepEd) is mandated to protect and promote the right of every Filipino citizen to quality education that will enable each learner to realize their full potential and meaningfully take part in nation-building. Actualizing this constitutional right is the main thrust of the $\mathrm{K}$ to 12 Basic Education Program which recognizes the diversity of the country's learners, schools, and communities. Seeking to be inclusive, $\mathrm{K}$ to 12 has broadened the goals of basic education in response to the varied realities of learners and their families by providing a wider range of options not only in preparing them for higher education, but also for opportunities in employment and entrepreneurship. $\mathrm{K}$ to 12 further promotes the implementation of programs that address the various physical, intellectual, psychosocial, and cultural needs of learners in diverse contexts. These programs are anchored on inclusion which is a core principle of the Enhanced Basic Education Program (DepEd Order No. 43, s. 2013).

2. The principle of inclusion promotes institutional sensitivity and responsiveness to the nature, situation, and realities of our country's learners and directs the Department to proactively address these through the curriculum and other interventions. This is institutionalized by $\mathrm{K}$ to 12 through Inclusive Education, a policy perspective realized through the development and implementation of learnercentered and context-responsive programs.

3. This policy framework is being adopted to provide an overall framework of implementation for programs that directly promote Inclusive Education and to ensure that every aspect of the $\mathrm{K}$ to 12 curriculum support system, across the governance levels of the Department, is responsive to the needs and demands of diverse learners.

\section{Legal Bases}

4. The principle of inclusion as a basis for development initiatives including education has been highlighted in international legal and standard-setting instruments, and Philippine laws. These laws and instruments are premised on the fundamental importance of recognizing the right to quality basic education of all learners, especially the disadvantaged and marginalized, who may be in unique situations and have different learning needs due to their personal, social, cultural, and economic context. These serve as pillars of this Inclusive Education Policy Framework.

\section{A. International Legal and Standard-setting Instruments}

a. The $\mathbf{1 9 8 9}$ Convention on the Rights of the Child upholds the rights of children and changed the way children are viewed and treated-from passive objects of care and charity to human beings with a distinct set of rights. 
b. The $\mathbf{1 9 9 4}$ Salamanca Statement provides that all children should learn together, wherever possible, regardless of any difficulties or differences they may have.

c. The United Nations Convention on the Rights of Persons with Disabilities (UNCRPD) aims to promote, protect, and ensure the full and equal enjoyment of all human rights and fundamental freedoms by all persons with disabilities, and to promote respect for their inherent dignity. More specifically, Article 24 of the UNCRPD states that "the right of persons with disabilities to education must be recognized with a view to realizing this right without discrimination and on the basis of equal opportunity" and General Comment 4 outlines what inclusive education is and what countries must do to make it happen (UN Committee on the Rights of Persons with Disabilities (CRPD), 2016).

d. The $\mathbf{2 0 0 7}$ United Nations Declaration on the Rights of Indigenous Peoples stipulates that Indigenous Peoples (IPs) have the right to establish and control their educational systems and institutions and that indigenous individuals, particularly children, have the right to all levels and forms of education without discrimination.

e. The Education 2030 Framework for Action aims at mobilizing all countries and partners around the Sustainable Development Goal (SDG) on inclusive and equitable quality education and lifelong learning opportunities for all.

\section{B. Philippine Legal Mandates for Inclusive Education}

a. The 1987 Philippine Constitution (Article XIV, Sections 1 and 2) explicitly upholds the protection and promotion of the right of all citizens to quality education at all levels, which requires the Philippine government, among others, to:

i. Establish, maintain, and support a complete, adequate, and integrated system of education relevant to the needs of the people and society (Section 2(1));

ii. Encourage non-formal, informal, and indigenous learning systems, as well as self-learning, independent, and out-of-school study programs particularly those that respond to community needs (Section 2(4)); and

iii. Provide adult citizens, the disabled, and out-of-school youth with training in civics, vocational efficiency and other skills (Section 2(5)).

b. Republic Act No. 10533 otherwise known as The Enhanced Basic Education Act of 2013, and its Implementing Rules and Regulations (IRR), define the inclusiveness of enhanced basic education through the implementation of programs designed to address the physical, intellectual, psycho-social and cultural needs of learners, which shall 
include, but shall not be limited to, Programs for Learners with Disabilities, Programs for Learners under Difficult Circumstances, Madrasah Program, Indigenous Peoples Education Program, and Programs for the Gifted and Talented (Section 8).

c. Republic Act No. 9710 otherwise known as The Magna Carta of Women, and its Implementing Rules and Regulations (IRR), compels the State to provide equal access and to eliminate discrimination in education, scholarships, and training (Section 13). This includes admission, curriculum and educational materials, delivery using gendersensitive language, and capacity-building on Gender and Development (GAD), peace and human rights for teachers and those involved in the education sector.

d. Republic Act No. 10157 or The Kindergarten Education Act released in 2012 declares the policy of the State to provide equal opportunities for all children to avail of accessible mandatory and compulsory kindergarten education that effectively promotes physical, social, intellectual, emotional and skills stimulation and values formation to sufficiently prepare them for formal elementary schooling.

e. Republic Act No. 9155 otherwise known as The Governance of Basic Education Act of 2001 enforces the establishment of the Alternative Learning System (ALS) to provide out-of-school youth and adults with basic education.

f. Republic Act No. 8371 otherwise known as The Indigenous Peoples Rights Act of 1997 mandates the State to provide equal access to various cultural opportunities to ICCs (Indigenous Cultural Communities]/IPs through the education system without prejudice to their right to establish and control their educational systems and institutions by providing education in their own language, and in a manner appropriate to their cultural methods of teaching and learning (Article II, Section 2).

g. Republic Act No. 9344 or The Juvenile Justice and Welfare Act of 2006 requires educational institutions to work together with families, community organizations and agencies in the prevention of juvenile delinquency and in the rehabilitation and reintegration of child in conflict with the law.

h. Republic Act No. 9442 (approved in 2007) or An Act Amending Republic Act No. $\mathbf{7 2 7 7}$ of 1992, otherwise known as the Magna Carta For Disabled Persons mandates the provision of educational assistance to persons with disabilities, for them to pursue primary, secondary, tertiary, post tertiary education, as well as vocational or technical education, in both public and private schools.

i. Republic Act No. 10665 of 2015 also known as the Open High School System Act declares the policy of the state to broaden access to relevant quality education through the employment of an alternative secondary 
education program to overcome personal, geographical, socio-economic, and physical constraints.

j. Republic Act No. 10361 approved in 2013 otherwise known as the Domestic Workers Act or Batas Kasambahay guarantees that the Kasambahay is afforded the opportunity to finish basic education, which shall consist of elementary and secondary education and mandates the DepEd to ensure their continued access to ALS (Rule IV, Section 16).

k. Republic Act No. 7610 of 1992 also known as Special Protection Against Abuse, Exploitation and Discrimination Act declares that it is a State policy to provide special protection to children from all forms of abuse, neglect, cruelty, exploitation and discrimination, and other conditions prejudicial to their development; provide sanctions for their commission and carry out a program for prevention and deterrence of and crisis intervention in situations of child abuse, exploitation and discrimination.

\section{Scope}

5. This policy framework shall guide DepEd programs, both in formal education system and alternative learning system, and in public and private schools; and the support systems that enable their effective implementation.

\section{Definition of Terms}

6. For the purposes of this policy framework, the following terms are defined:

a. Context refers to the particular setting, situation, or circumstance of the learner influenced by personal, cultural, political, social, and economic factors (e.g. disability, ethnicity, gender, religion, socialization in the family and the wider community, social history, economic status, personal capabilities, available resources), as well as the specific environment in which the learner lives, interacts with other people, and where learning takes place.

b. Equity refers to the value of securing the right to education of all learners, and their rights within and through education to realize their potentials and aspirations.

c. Equitable refers to the rights-based appropriation of resources and opportunities for all learners.

d. Learner refers to any individual, regardless of age, sex, gender, disability, ethnicity, cultures, and religion, enrolled in basic education to enhance his/her knowledge, skills and values to improve the quality of his/her life and to develop his/her potentials.

e. Learning Environment refers to learning facilities, resources and technology, means of teaching, modes of learning, and connections to 
community, societal and global contexts towards the total development of the learner.

f. Universal Design for Learning (UDL) is a framework to improve and optimize teaching and learning for all people based on scientific insights into how humans learn (Center for Applied Special Technology 2017).

\section{Policy Statement}

7. The Department adopts this policy framework to provide policy guidance in the establishment, implementation, monitoring and evaluation of programs and interventions with strategies and support mechanisms that adequately respond to diverse educational needs and contexts of learners.

\section{Guiding Principles}

8. The Department adheres to the following guiding principles in the pursuit of Inclusive Education:

\section{A. Inclusion}

9. All learners shall have access to and participate in all aspects of life in school, in learning centers and other places of learning.

\section{B. Responsiveness to Rights}

10. Inclusive Education contributes to the realization of the Department's commitment to quality, equitable, culture-based, and complete basic education which is premised on its mandate to protect and promote the right of every Filipino citizen to such education services. The Department subscribes to the Rights-based Approach (RBA), which highlights the recognition, promotion, and protection of rights as the basis for initiatives, and focuses on people empowerment through the introduction and use of the concept of rights as legal entitlements of the people and legal obligations of the government to its people.

\section{Sensitivity and Responsiveness to Context}

11. $\mathrm{K}$ to 12 recognizes and values the diverse contexts of learners, schools, and communities, and this diversity guides the design and delivery of basic education programs and interventions.

\section{Key Dimensions}

\section{A. The Learners}

12. DepEd recognizes the right of each and every learner to an education that is learner-centered, relevant and appropriate in relation to the learner's context. Thus, education programs shall be responsive to all learners regardless of sex, 
disability, culture, ability, age, ethnicity, social class, religious beliefs and other characteristics.

13. The learners are the primary stakeholders of the Department's inclusive basic education system. Learners' participation and representation shall be encouraged in school organizations, in curricular and co-curricular activities, and in education planning, program development and implementation, where appropriate.

\section{B. The $\mathrm{K}$ to 12 Curriculum}

14. Inclusion is a key standard and principle of the $\mathrm{K}$ to 12 curriculum and its actualization is supported by other standards and principles that further describe the features of an inclusive curriculum- learner-centered, developmentally appropriate, culture-sensitive, relevant, gender-responsive, and contextualized.

15. Thus, the perspective of Inclusive Education is at the core of the $\mathrm{K}$ to 12 curriculum and is embedded in the curriculum framework itself. This is demonstrated by the Mother Tongue-based Multilingual Education (MTB-MLE) policy for $\mathrm{K}$ to 3 , the varied offerings of Technology and Livelihood Education (TLE) in Junior High School, and the tracks and strands of Senior High School, all of which are meant to be responsive to the varied context of the country's learners.

16. K to 12's standards-based curriculum was also designed to be flexible enough for schools and local communities to contextualize in relation to the learner's ability, socio-cultural background, historical context, and bio-geographical realities. Curriculum contextualization provides an avenue to be inclusive of the values, beliefs, practices, and knowledge systems of the learner's community. Schools, learning centers and communities should be able to provide this kind of contextualization.

17. The inclusiveness of $\mathrm{K}$ to 12 is also expressed through existing programs such as Special Education, Indigenous Peoples Education, Madrasah Education, and Flexible Learning Options including Alternative Delivery Modes and Alternative Learning System, which address the context and needs of particular learners. Special Interest Programs also cater to learners who manifest the interest and aptitudes for particular skillsets.

18. To ensure that curriculum contextualization and the implementation of the various programs of the $\mathrm{K}$ to 12 curriculum actualize inclusion, and continue to promote equality and equity in developing the learners' competencies through quality differentiated instruction, the following shall be strengthened and continue to be pursued:

a. Recognition and development of programs or initiatives to address contexts, needs and concerns not covered by existing programs and initiatives of DepEd;

b. Contextualization of the curriculum and learning materials at the school level;

c. Differentiated presentation of information, content, and learning materials to support understanding; 
d. Provision of opportunities for learners to create, learn and share what they know in both curricular and non-curricular activities;

e. Provision of equitable and appropriate learning opportunities for all learners to facilitate active participation and shared responsibility and accountability in the teaching-learning process; and,

f. Removal of barriers to learning and participation.

\section{Development of Learning Resources}

19. Aligned with the principles of an inclusive and contextualized curriculum is the development of contextualized learning resources which is stipulated in RA 10533. Both contextualized teaching and learning materials shall be developed and produced at the field offices based on standards set by the Bureau of Learning Resources. These will complement the instructional materials provided by the Department and external partners/stakeholders.

20. Learning resources (text and non-text based) shall be utilized to engage learners in active participation and interaction using different contexts that promote real life application. The diversities of learners' abilities, knowledge, learning styles, study habits, interests, motivation, multiple intelligences and other circumstances must be considered in the preparation, development, and delivery of contextualized learning materials and activities. As mentioned in the $\mathrm{K}$ to 12 Policy, some of these learning resources are also transcribed into Braille and adapted in other ways (e.g. like having a sign language interpreter in class) to ensure that all learners have access to these materials).

21. Quality assurance processes shall ensure that learning resources produced are free from any discriminatory content, are appropriate to diverse learners, and are sensitive to social and cultural contexts.

22. The community as a learning resource shall also be developed and maximized.

23. The Learning Resource Portal as a repository of learning and teaching resources shall be utilized and maximized.

\section{Learning Delivery}

24. The inclusiveness of the $\mathrm{K}$ to 12 curriculum can be better experienced by learners in the teaching-learning process when different and diverse learners learn together and the delivery of educational programs and services is also made flexible based on the profile, needs, and context of the learners.

25. Learning sessions shall be based on inclusive and learner-centered pedagogy. Teachers shall regularly monitor learner's progress and provide appropriate support including timely interventions, as needed.

26. Schools are encouraged to offer a range of programs that shall serve as a menu of options for different types of learners to ensure that "no learner is left behind".

27. Teachers and instructional managers shall maintain an inclusive atmosphere and promote respect at all times, and will take steps to assure that initiatives geared 
towards differentiated instruction to address varied learning needs shall not be misconstrued by learners and the immediate community as segregation, nor will be a cause of bullying or discrimination.

28. The school shall ensure the following:

a. Undertaking of anticipatory and proactive initiatives geared towards gaining a better understanding of the learners' contexts and needs;

b. Recognition of barriers to inclusion and removal of these by putting in place programs and services that adhere to the principles of universal design for learning;

c. Development of school implementing policies, mechanisms, and strategies for delivering equal and equitable opportunities for diverse learners;

d. Involvement of stakeholders - the learners, their parents and/or caregivers, and the immediate community - in meeting learning standards and in identifying and addressing learning gaps of disadvantaged and marginalized learners;

e. Formulation of appropriate and responsive interventions for the disadvantaged and marginalized learners;

f. Enhancement of curriculum implementation by aligning teachinglearning processes, formative and summative assessments and the learning standards deemed appropriate to the learners' context; and

g. Regular monitoring and evaluation of initiatives by actively involving the learners and other stakeholders as appropriate.

\section{E. Educational Assessment}

29. The learner-centered orientation of the $\mathrm{K}$ to 12 curriculum and curriculum contextualization also necessitates that learning assessment be inclusive.

30. Inclusive assessment provides learners varied opportunities to test their mastery of competencies and enables them to participate in several types of activities that enhance their understanding of concepts and ideas. Classroom assessment shall take into account the needs of all learners through the use of varied assessment strategies, methods and tools/equipment such as, but not limited to, tests (oral and written), multiple-choice questions, group presentations, self and peer assessment, role play, creation of audiovisual materials, performance, diaries and portfolio. Assessments shall be adapted according to the principles of universal quality educational design (UDL).

\section{F. Learning Environment}

31. From the physical environment to the teaching-learning process, these learning environments shall be fully accessible and shall enable all learners to feel safe, supported, stimulated, and respected as they express themselves as part of a positive and inclusive school community.

32. The teaching and learning process shall foster learning in a collaborative and barrier-free setting, promoting the learners' overall well-being and holistic development. Education shall be delivered in the most appropriate language/s and 
modes and means of communication for the individual, and in environments which maximize academic and social development.

33. Further, an inclusive educational environment shall be context-sensitive and consider the bio-geographical realities and socio-cultural background of learners. Schools and learning centers are strongly encouraged to engage in regular dialogue with their immediate community, which inherently plays a big role in providing an inclusive learning environment.

34. Apart from the availability and accessibility of functional support facilities such as, but not limited to, water and sanitation facilities, clinic, library, Guidance Office, and Community Learning Centers (CLCs), effective individualized support measures shall be provided when needed and appropriate.

35. Finally, the learning community shall promote harmonious relationships and respect for diversity and practice of positive discipline among learners, teachers, parents, and administrators. It shall ensure that anti-bullying, anti-abuse, and child protection measures and procedures are in place.

\section{G. Teacher Professional Development}

36. All teachers shall be considered primary implementers of inclusive education. As such, they shall possess the proper values, perspectives, attitudes, as well as competencies that communicate and reflect inclusion as they address the educational needs of diverse learners. The Philippine Professional Standards for Teachers (PPST) includes Domain 3: Diversity of Learners which underscores the importance of teachers' knowledge and understanding of, as well as respect for, learners' diverse characteristics and experiences as inputs to the planning and design of learning programs. This includes being able to implement an individualized education program if and when necessary. The Department recognizes the PPST as a major reference in designing interventions geared towards the professional development of teachers, including teacher aides and teacher volunteers. They shall also be capacitated in establishing learning environments that are responsive to learner diversity.

37. The competencies of teachers, instructional managers and other non-teaching personnel shall be continuously enhanced so that they can create an inclusive learning environment that promotes inclusion of all learners, and facilitates teaching and learning processes that addresses diverse learning styles and needs. Capacitybuilding activities may include, but are not limited to, the Teacher Induction Program (TIP), In-Service Trainings (INSETs), attendance in seminar-workshops/conferences, Learning Action Cell (LAC) sessions, immersion, community engagement, coaching, mentoring and benchmarking.

38. DepEd through the Teacher Education Council (TEC) shall collaborate with the Technical Education and Skills Development Authority (TESDA) and Commission on Higher Education (CHED) to ensure the integration of Inclusive Education in all major courses in the Teacher Education Programs (TEP). In the same way, the implementation of Inclusive Education shall influence policies on teacher qualifications, hiring, recruitment, and deployment. 
39. Participation of stakeholders, especially those directly involved in the teaching-learning process, shall be encouraged. They shall likewise be engaged through periodic consultations to further strengthen the implementation of Inclusive Education.

\section{H. School Leadership and Management}

40. All schools shall be guided by DepEd's mission to promote and protect the right of every Filipino to quality, equitable, culture-based and complete basic education. This is premised on upholding a deep respect for the inherent dignity of individuals and communities.

41. To this end, schools are guided by the perspective of Inclusive Education in contextualizing and implementing the $\mathrm{K}$ to 12 curriculum, and are encouraged to implement programs that promote inclusion and cater to the various interests of learners to respond to the context of the learners and the communities being served.

42. The school head has a pivotal role in bringing about inclusive school change (Riehl 2000; Day and Leithwood 2007; Ainscow and Sandill, 2010). They shall assist teachers in creating inclusive classrooms. School mechanisms and process governance mechanisms and processes shall be geared towards facilitating the provision of, but not limited to, the following:

a. Technical support in contextualizing the curriculum and teachinglearning materials, and using learning-centered pedagogy and inclusive assessment;

b. Physical infrastructures that facilitate inclusion; and,

c. Continuous capacity-building on inclusive education of teaching and nonteaching personnel (e.g. LAC sessions, In-Service Trainings, mentorship).

43. They shall also support the development of research-based improvements in instruction and school management for Inclusive Education. Practices and innovations shall be properly documented for sharing, replication, and for continuous improvement.

44. All school heads shall be capacitated to prepare and manage schools that promote and implement Inclusive Education. They must adhere to the new Philippine Professional Standards for School Heads (currently being validated) that contain competencies related to supporting Inclusive Education in schools. School-based Management (SBM) shall strengthen the implementation of Inclusive Education, which shall be duly reflected in the School Improvement Plan (SIP).

\section{Partnerships for Inclusive Education}

45. The Department at all levels of governance shall continuously conduct intensive advocacy and social mobilization on Inclusive Education as a perspective, policy, and practice. Support for initiatives in curriculum contextualization and the development of contextualized learning resources are just some activities for which internal and external partners/stakeholders can be tapped.

46. Continuous engagement with the stakeholders/partners shall be institutionalized in the planning, implementation, monitoring and evaluation of 
curricular and co-curricular programs and activities to ensure quality implementation of Inclusive Education.

47. External linkages and partnerships must be expanded and strengthened to ensure proper coordination, resource sharing, and sustainability of Inclusive Education implementation.

\section{J. Governance Support}

48. The Department shall adequately consider the specific needs to realize Inclusive Education in the planning and programming of resources, such as in the provision of program funds, allocation of teacher items and hiring of teachers, resources for adequate instructional print and non-print learning resources, facilities and equipment needed, and support to professional development of teaching and non-teaching staff. National planning standards shall be responsive to the diversity of learning contexts.

49. The Department shall continuously coordinate with LGUs to maximize the utilization of the Special Education Fund (SEF) and other available local resources. The involvement of internal and external stakeholders shall also be encouraged to support the implementation of inclusion programs.

\section{Monitoring and Evaluation}

50. The Bureau of Learning Delivery (BLD), in coordination with other offices in the Curriculum and Instruction Strand and other organizational strands of the Department, is responsible for learning environment standards to strengthen the curriculum implementation support system. It shall provide technical assistance on the implementation of this policy in schools and learning centers. It shall also monitor regional offices for adequate implementation of this policy. For Indigenous Peoples Education, a monitoring and evaluation system that is culturally sensitive and responsive to the context of IP learners and communities, recognizing the interface of the national education system and indigenous learning systems, shall be maintained across governance levels and continue to be strengthened through the Indigenous Peoples Education Office (IPsEO).

51. The Regional and Schools Division Offices shall likewise conduct monitoring and evaluation at the division and school levels, respectively. The different units in the Regional and Schools Division Offices shall ensure that schools and programs are inclusive in terms of the curriculum and its support systems. 


\section{References}

1987 Constitution of the Republic of the Philippines

Ainscow, Mel and Sandill, Abha. "Developing Inclusive Education

Systems: the Role of Organisational Cultures and Leadership."

International Journal of Inclusive Education, 14:4, 401-416. DOI:

$10.1080 / 13603110802504903$

Center for Applied Special Technology, "About Universal Design for

Learning," (http://www cast.org/our-work/about-udi.html\#.

WUj6u5KGMdU) accessed 20 June 2017.

Day, Christopher \& Leithwood, Kenneth Arthur, eds. Successful

Principal Leadership in Times of Change. An International

Perspective. Dordrecht, The Netherlands: Springer, 2007.

Implementing Rules and Regulations of R.A. 10533, "The Enhanced Basic Education Act of 2013."'

Republic Act 7610, "An Act Providing for Stronger Deterrence and Special Protection against Child Abuse, Exploitation and Discrimination, and for Other Purposes"

Republic Act 9155, "Governance of Basic Education Act of 2001"

Republic Act 9344, "The Juvenile Justice and Welfare Act"

Republic Act 9442, "An Act Amending RA 7277 otherwise known as the "Magna Carta for Disabled Persons and Other Purposes"

Republic Act 9710, “The Magna Carta of Women”

Republic Act 10157, "Kindergarten Education Act of 2012"

Republic Act 10361, "Domestic Workers Act" or "Batas Kasambahay"

Republic Act 10533, "The Enhanced Basic Education Act of 2013"

Riehl, Carolyn. "The Principal's Role in Creating Inclusive Schools for Diverse Students: A Review of Normative, Empirical, and Critical Literature on the Practice of Educational Administration." Review of Educational Research, 70(1) (2000): 55-81. doi: 10.3102/00346543070001055.

United Nations. "Agenda 2030 for Sustainable Development" (http://www.sustainabledeveloment.un.org)

United Nations. "2007 Declaration on the Rights of Indigenous Peoples," (http://www.un.org/esa/socdev/unpfii/documents/DRIPS_en.pdf)

UN Committee on the Rights of Persons with Disabilities (CRPD), "General 
comment No. 4 (2016), Article 24: Right to inclusive education, 2 September 2016, CRPD/C/GC/4,"

(Int1p:/www.un.org/development/desa/disabilities/convention-on-theIghts-of-persons-with-disabilities.html] accessed 24 March 2019

United Nations Educational, Scientific and Cultural Organization, "The Salamanca Statement and Framework for Action on Special Needs Education," (http://www.unesco.org/education/pd//SALAMA E.PDF) accessed 9 May 2017.

United Nations Educational, Scientific and Cultural Organization, "World Declaration on Education for All," (http://unesdoc.unesco.org/ images/0012/001275/127583e .pdf) accessed 9 May 2017.

United Nations General Assembly. "1990 Convention on the Rights of the Child," (https//: www unicef.org./crc.)

United Nations General Assembly, "Convention on the Rights of Persons with Disabilities,"

(hilos:/www un org/development/desa/disabilities/convention-on-therights of persons-with-disabilities.html accessed 24 March 2018 